\title{
SPARTA, NEW JERSEY, FLOOD OF AUGUST 11-14, 2000
}

Water-Resources Investigations Report 02-4099

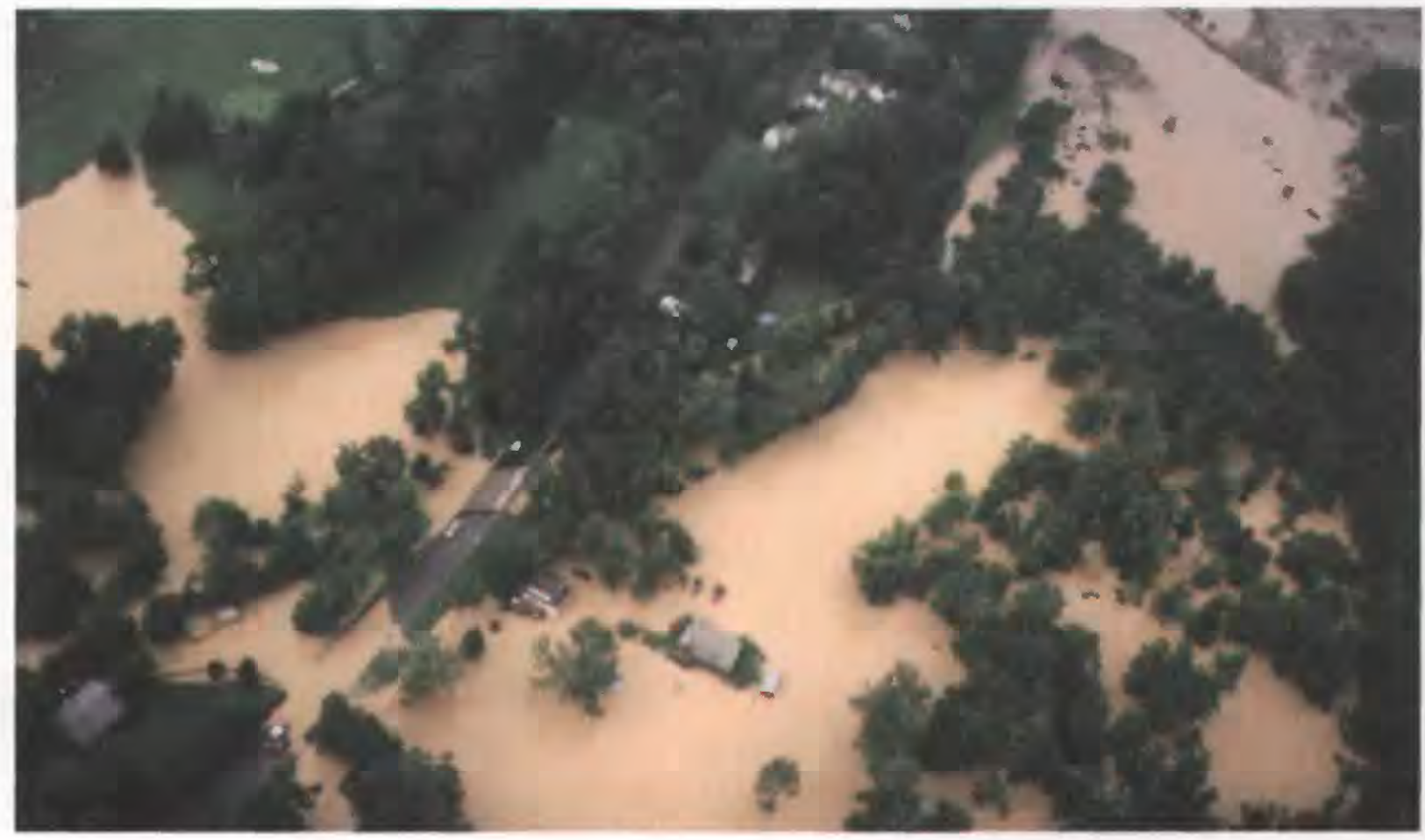

Prepared in cooperation with the

Federal Emergency Management Agency 
Cover photo: Aerial photograph of flooding along the Wallkill River in the vicinity of County Route 631 in Franklin Borough, August 12, 2000.

Photograph taken by Joyce Bambach, staff photographer for Sussex County Sheriff's Office, Division of Emergency Management. 
SPARTA, NEW JERSEY, FLOOD OF AUGUST 11-14, 2000

By Robert G. Reiser and Robert D. Schopp

U.S. Geological Survey

Water-Resources Investigations Report 02-4099

Prepared in cooperation with the

Federal Emergency Management Agency

West Trenton, New Jersey

2002

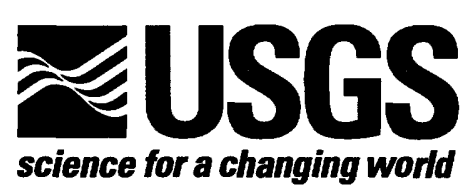




\section{U.S. DEPARTMENT OF THE INTERIOR}

GALE A. NORTON, Secretary

\section{U.S. GEOLOGICAL SURVEY}

Charles G. Groat, Director

For additional information write to:

District Chief

U.S. Geological Survey

Mountain View Office Park

810 Bear Tavern Road

West Trenton, NJ 08628
Copies of this report can be purchased from:

U.S. Geological Survey

Branch of Information Services

Box 25286

Denver, CO 80225-0286 


\section{CONTENTS}

Abstract

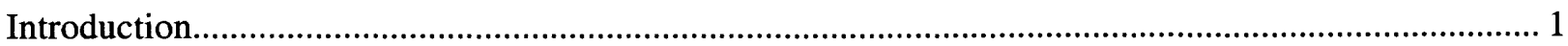

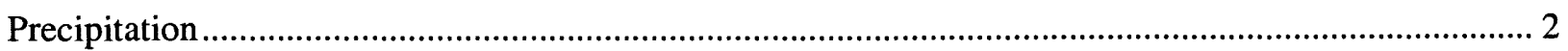

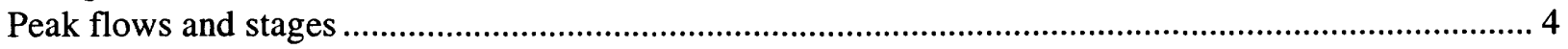

Records set at established U.S. Geological Survey gaging stations ....................................... 6

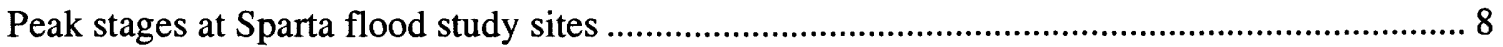

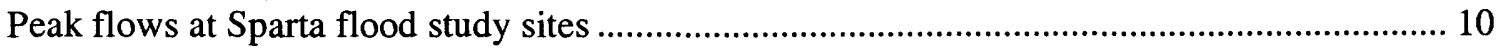

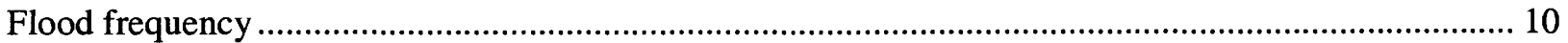

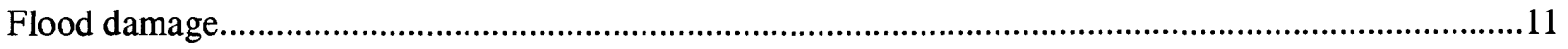

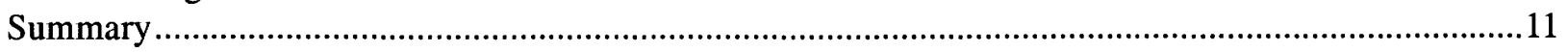

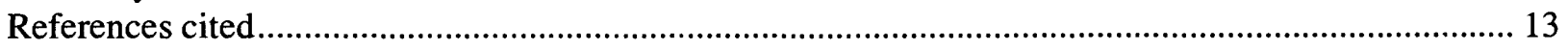

Appendixes

1. Site descriptions of and high-water marks at 21 selected stream sites, flood of

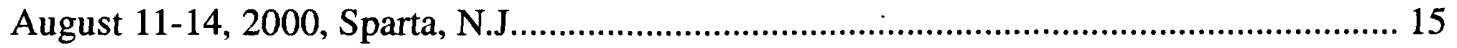

2. Summary of indirect discharge measurements made at Glen Brook near Sparta, N.J., and

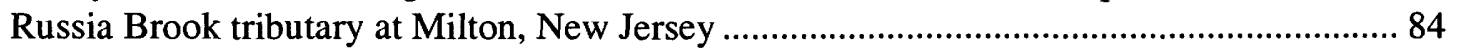

\section{ILLUSTRATIONS}

Figure 1. Map showing total rainfall at 41 gages in northern New Jersey during August 11-14, 2000 . 1

2. Map showing estimated total precipitation in New Jersey, August 12, 2000

(0700), to August 13, $2000(0700)$

3. Map showing high-water-mark sites, flood frequency at U.S. Geological Survey gaging stations experiencing a flood event with a recurrence interval greater than 2 years, and total rainfall at rain gages within a 10 -mile radius of Sparta, N.J.

4. Map showing location of high-water-mark sites chosen for Sparta flood study, northwestern New Jersey

5. Graph showing historical peak unit-runoff values at U.S. Geological Survey streamflow-gaging stations in northwestern New Jersey and the four highest peak unit-runoff values measured during August 12-14, 2000.

6. Graph showing historical peak runoff values at selected U.S. Geological Survey streamflow-gaging stations in northwestern New Jersey and peak runoff values during August 12-14, 2000 ...

\section{TABLES}

Table 1. Total precipitation for the period August 11-14, 2000, at rain gages within approximately a 10 -mile radius of Sparta, N.J.

2. Historical flood peaks and flood peaks during the August 12-14, 2000, flood at U.S. Geological Survey gages in northwestern New Jersey where the recurrence interval of the peak flow was greater than 2 years

3. Peak flood elevations at 21 high-water-mark sites in the vicinity of Sparta, New Jers $9 y$, during the August 12-14, 2000, flood 


\section{CONVERSION FACTORS, VERTICAL DATUM, AND ABBREVIATED UNITS}

Multiply

foot (ft)

mile (mi)
By

\section{Length}

2.54

0.3048

1.609

\section{$\underline{\text { Area }}$}

square mile $\left(\mathrm{mi}^{2}\right)$

square mile $\left(\mathrm{mi}^{2}\right)$

259.0

2.590

Volume

cubic foot $\left(\mathrm{ft}^{3}\right)$

cubic foot per second $\left(\mathrm{ft}^{3} / \mathrm{s}\right)$

cubic foot per second per square mile

[(ft3/s)mi2]

To obtain

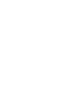




\section{SPARTA, NEW JERSEY, FLOOD OF AUGUST 11-14, 2000}

\section{by Robert G. Reiser and Robert D. Schopp}

\section{ABSTRACT}

More than 14 inches of rain deluged parts of southeastern Sussex and northwestern Morris Counties in northwestern New Jersey during August 11-14, 2000. A severe thunderstorm on August 12 produced as much as 90 percent of the total 4-day rainfall. This storm resulted in a 1,000year event for total rainfall in a 6 -hour period. About 2,700 homes and businesses in western Morris, southeastern Sussex, and parts of Warren and Hunterdon Counties along the Musconetcong River were flooded. About 2,600 people in Morris, Sussex, and Hunterdon Counties were evacuated. Four dams in Sussex County failed completely and 26 dams in Morris and Sussex Counties sustained damage. Damage was estimated at $\$ 179$ million, and Morris and Sussex Counties were declared Federal disaster areas.

Flood peaks at some U.S. Geological Survey stream-gaging stations on Lake Hopatcong, Musconetcong River, Green Pond Brook, Rockaway River, and Russia Brook tributary were the highest ever recorded. Elevations of flood peaks at most of the study sites along the Wallkill River from Sparta downstream to Hamburg and at Russia Brook tributary at Milton equaled or exceeded the 500-year flood elevation as calculated by the Federal Emergency Management Agency. Because the area of record-breaking rainfall was limited in extent, however, flood peaks at many other gaging stations in northwestern New Jersey were much smaller.

\section{INTRODUCTION}

As much as 18.6 in. of rain deluged parts of southeastern and northwestern Morris Counties in northwestern New Jersey during August 11-14, 2000 (fig. 1). A severe thunderstorm on August 12 produced 80 to 90 percent of the total 4-day rainfall in a 6-hour period from 9 a.m. to 3 p.m. Rainfall was greatest in Sparta and Jefferson Townships, along the Sussex/Morris County border, where

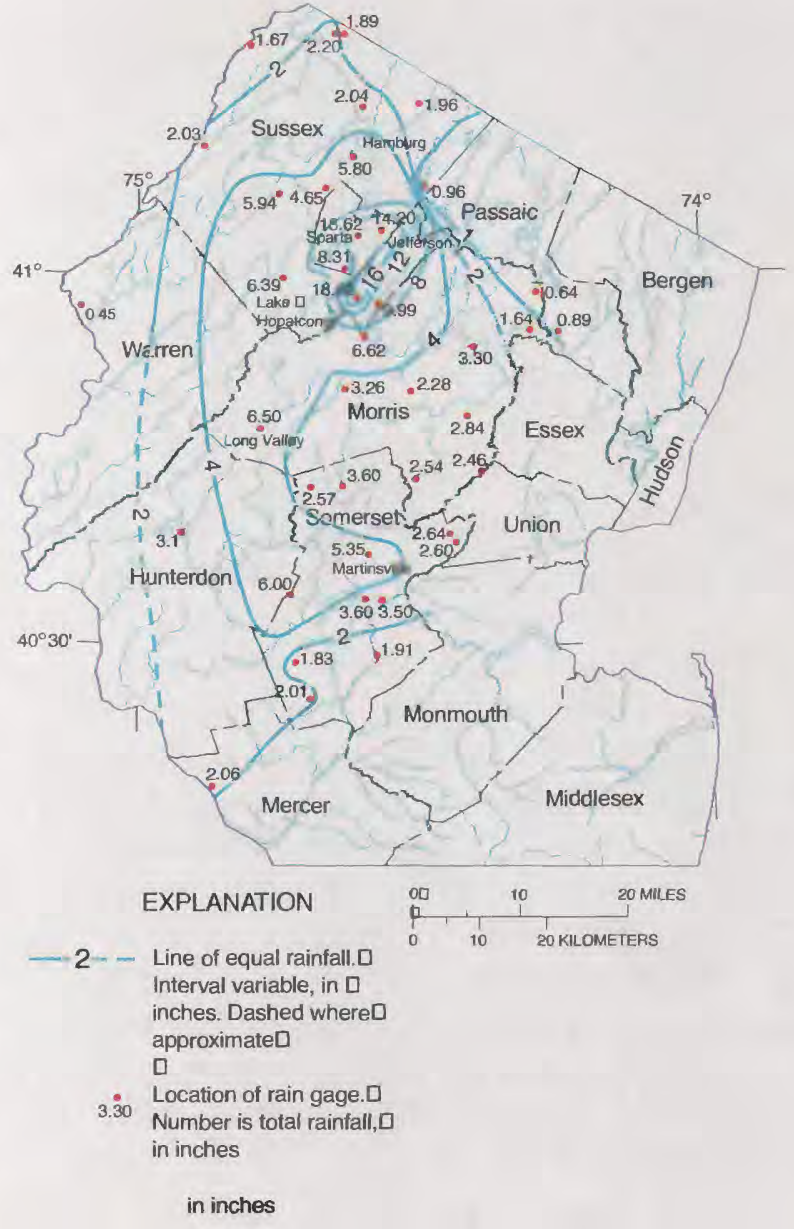

Figure 1. Total rainfall at 41 rain gages in northern New Jersey during August 11-14, 2000. (Data from National Weather Service, Sussex County Weather Network, Town of Newton, N. J., and U.S. Geological Survey)

total rainfall was estimated by Doppler radar to reach approximately 15 in. (fig. 2; National Weather Service, 2000). Rainfall intensity during the August 12 thunderstorm was from 2 to $3 \mathrm{in} / \mathrm{hr}$.

This report prepared by the U.S. Geological Survey (USGS), in cooperation with the Federal Emergency Management Agency (FEMA), documents total rainfall amounts in northwestern New Jersey during August 11-14; describes the 
resulting peak streamflows, peak stages, and flood frequencies at USGS streamflow-gaging stations and other selected sites in the area; and gives an overview of the damage caused by the storms that occurred during this period.

The authors gratefully acknowledge those who helped with the field work for this project. Timothy J. Reed, John F. Dudek, Richard Edwards, and Gimena Bosonetto flagged, documented, and photographed high-water marks. Peter J. Cinotto, Elaine S. Gee, Suzanne W. Babula, and Christopher D. Schaefer surveyed the high-water marks. Richard Edwards and Guy Holzer helped to survey the indirect-measurement sites.

\section{PRECIPITATION}

Unusually large amounts of rain produced by a series of thunderstorms deluged parts of northwestern New Jersey during August 11-14, 2000. Rainfall was greatest in parts of southeastern Sussex County and northwestern Morris County (fig. 1). Rain gages in the municipalities of Sparta and Jefferson Townships in Sussex and Morris Counties, respectively, recorded the most rain. Privately owned rain gages in Jefferson Township and on Sparta Mountain recorded 18.65 and 14.11 in., respectively, over the 4-day period. Both of these gages are part of the Sussex County Weather Network. Most of the rain fell during a storm on August 12 that lasted approximately 6 hours. A rain gage at Newton Reservoir (Morris Lake) in Sparta Township, operated by the town of Newton, recorded $13.62 \mathrm{in}$. More than 12 in., or nearly 90 percent, of the total rainfall at this site fell on August 12.

The rain was most intense from 9 a.m. to 3 p.m. on August 12, when precipitation rates nearly equaled the maximum recorded in the MidAtlantic Region. The greatest rainfall intensity estimated in northwestern New Jersey by Doppler radar on August 12 was approximately 15 in. in 6 hours ( $2.5 \mathrm{in} / \mathrm{hr}$ ) (National Weather Service, 2000). The greatest rainfall intensity in the MidAtlantic Region, 24 in. in 9 hours $(2.7 \mathrm{in} / \mathrm{hr})$ (U.S. Department of Commerce, 1958), was recorded at Ewan in Gloucester County in southern New Jersey from August 31 to September 1, 1940.
The areal extent of total rainfall amounts greater than 3 in. was limited. A map of estimated rainfall from Doppler radar (fig. 2; Weather Services International Corporation, 2000) shows the distribution of rainfall in New Jersey and adjacent parts of the surrounding States during August 12-13, 2000.

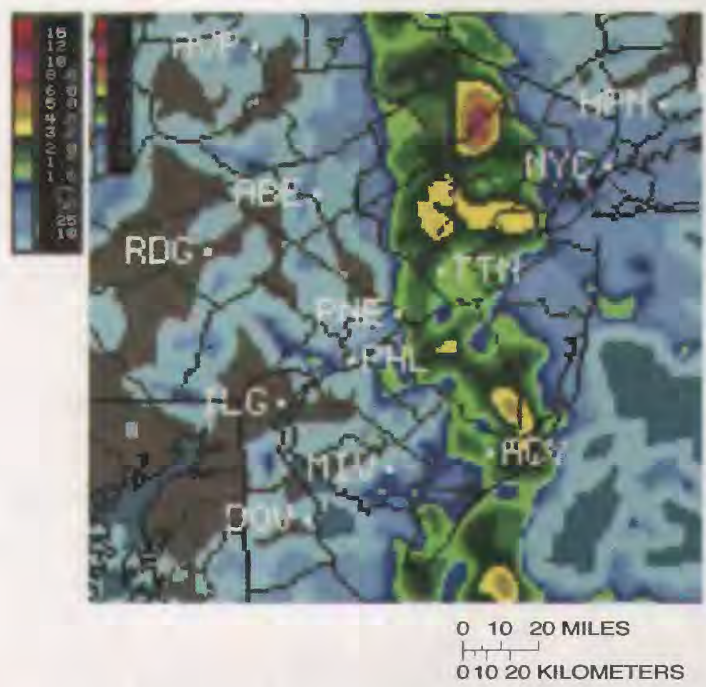

Figure 2. Estimated total precipitation in New Jersey, August 12, 2000 (0700), to August 13, 2000 (0700). (Data from National Weather Service Doppler radar; units are inches) (Weather Services International Corp., 2000)

Rainfall in northern New Jersey during August 11-14, 2000, was greatest at rain gages within a 10-mi radius of Sparta Township (table 1). More than $10 \mathrm{in}$. of rain fell in a limited area northwest of Berkshire Valley, east of Lake Hopatcong, north to eastern parts of Sparta Township and western parts of Jefferson Township (fig. 1). Rainfall was greatest in the headwaters of the Wallkill, Musconetcong, and Rockaway River Basins. Some gages as far south as Long Valley (20 mi from Sparta) in Morris County and Martinsville (30 mi from Sparta) in northern Somerset County recorded more than $5 \mathrm{in}$. of rain. Three rain gages northeast of State Route 23, 10 to 15 mi northeast of Sparta, recorded less than 1 in. of rain.

Long-term monthly and annual average precipitation in the region derived from monthly precipitation records (National Oceanic and Atmospheric Administration, National Climatic Data 
Table 1. Total precipitation for the period August 11-14, 2000, at rain gages within approximately a 10 -mile radius of Sparta, N.J.

[Data provided by personnel at the National Weather Service, the Sussex County Weather Network, and the Town of Newton, New Jersey]

\begin{tabular}{|c|c|c|}
\hline \multicolumn{2}{|c|}{ Rain-gage location } & \multirow{2}{*}{$\begin{array}{l}\text { Total precipitation } \\
\text { (inches) }\end{array}$} \\
\hline Locality & County & \\
\hline Andover & Sussex & 6.39 \\
\hline Berkshire Valley & Morris & 9.99 \\
\hline Canistear & Sussex & .96 \\
\hline Hamburg & Sussex & 5.80 \\
\hline Jefferson Township & Morris & 18.6 \\
\hline Lafayette & Sussex & 4.65 \\
\hline Morris Lake & Sussex & 13.6 \\
\hline Newton & Sussex & 5.94 \\
\hline Sparta & Sussex & 8.31 \\
\hline Sparta Mountain & Sussex & 14.1 \\
\hline West Wharton & Morris & 6.62 \\
\hline
\end{tabular}


Center, unpub. data accessed March 17, 2001, on the World Wide Web at URL ftp://

ftp.ncdc.noaa.gov/pub/data/cirs) were compared with rainfall during this storm. The average monthly and annual precipitation in Climate Division 1 in northern New Jersey, which encompasses the Piedmont, New England, and Valley and Ridge Physiographic Provinces, was used for comparison. The total annual precipitation during 1960-99 averaged 47.4 in., and the average during 1895-1999 was 46.0 in. Parts of Jefferson

Township received as much as 39 percent of the average annual precipitation for the region during this event. The monthly total precipitation for August from 1960 to 1999 averaged 4.25 in., and the average from 1895 to 1999 was 4.46 in. The total rainfall recorded at a gage in Jefferson Township was four times the long-term average for the month of August.

Average monthly precipitation records for New Jersey Climate Division 1 were used to characterize conditions during the 12 months preceding the August 11-14 flood. Average total precipitation for the region from August 1999 through July 2000 was $53.8 \mathrm{in.,} 6.4 \mathrm{in}$. above the average for 1960-99 (National Oceanic and Atmospheric Administration, National Climatic Data Center, unpub. data accessed March 17, 2001, on the World Wide Web at URL ftp://ftp.ncdc.noaa.gov/pub/data/cirs). Much of the surplus was attributed to rain associated with Hurricane Floyd in September 1999. Rainfall for the region in September averaged 12.0 in., $7.6 \mathrm{in}$. above normal. Rainfall during the 10 months prior to August 2000 averaged 1.9 in. below normal; rain for the period from May through July averaged $2.7 \mathrm{in}$. above normal.

\section{PEAK FLOWS AND STAGES}

Flood peaks recorded at USGS gaging stations on Lake Hopatcong, Musconetcong River, Green Pond Brook, Rockaway River, and Russia Brook tributary were the highest ever recorded (table 2). Flood peak at most of the study sites surveyed along the Wallkill River from Sparta downstream to Hamburg and at Russia Brook tributary at Milton (13 of the 18 locations studied on these streams) equaled or exceeded the 500year flood elevation as published by FEMA (Federal Emergency Management Agency, 1983a, 1983b, 1983c, 1983d, 1984a, 1984b) (fig. 3). A 500-year flood has only a 0.2 -percent chance of occurring in any given year.

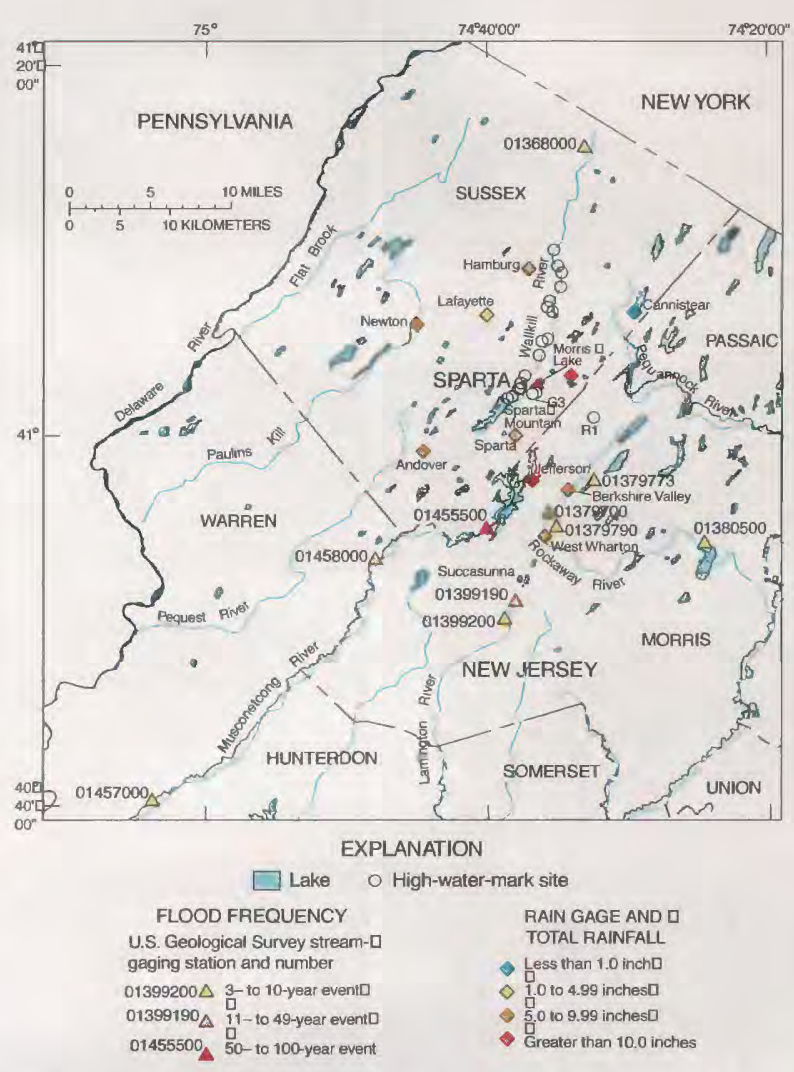

Figure 3. High-water-mark sites, flood frequency at U.S. Geological Survey gaging stations experiencing a flood event with a recurrence interval greater than 2 years, and total rainfall at rain gages within a 10-mile radius of Sparta, N.J.

Flood peaks at 35 established USGS gaging stations in northwestern New Jersey ranged from less than 2-year to 100-year events, reflecting the limited areal extent of the greatest rainfall amounts and the large variation in rainfall across the area (fig. 2). The flood peaks on Lake Hopatcong and on the Musconetcong River just downstream from the lake were greater than the 100-year recurrence-interval flood. A 40-year flood was recorded at the Rockaway River at Berkshire Valley and the gage on the Lamington River at Succasunna recorded a peak equal to a 12-year flood. Other USGS gaging stations in the area recorded flood peaks with a recurrence interval of less than 10 years, and many recorded peaks with a recurrence interval of less than 2 years (fig. 4). 


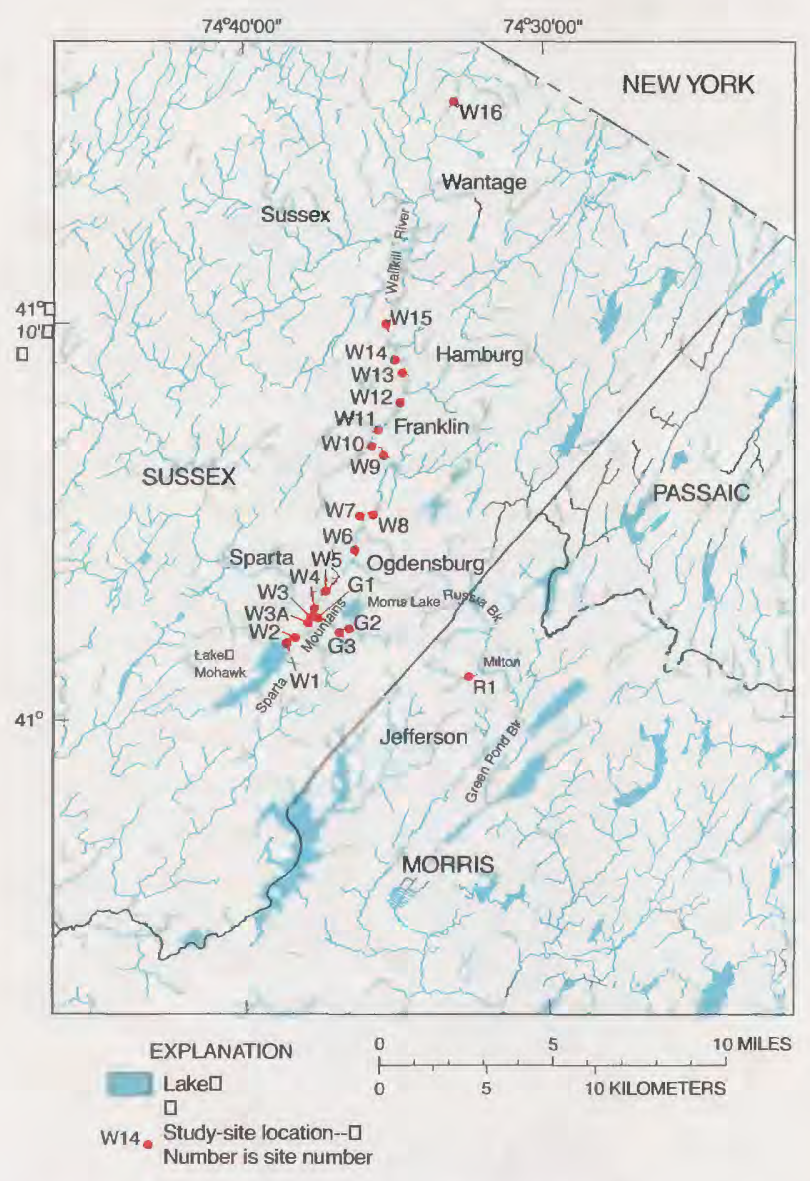

Figure 4. Location of high-water-mark sites chosen for Sparta flood study, northwestern New Jersey.

The maximum yields computed from measurements recorded by the USGS at selected sites during this flood are compared to historical maximum yields at these and other USGS sites in the region in figure 5. Peak flows recorded by the USGS at selected sites during this flood are compared to historical maximum flows at USGS sites in the region in figure 6 . The Jarvis envelope curve shown in these figures is an estimate of the unit runoff (fig. 5) or peak runoff (fig. 6) that is expected to occur (Thomas, 1964). The curve shown with a dotted line indicates the discharge equal to 50 percent of the discharge represented by the Jarvis envelope curve.

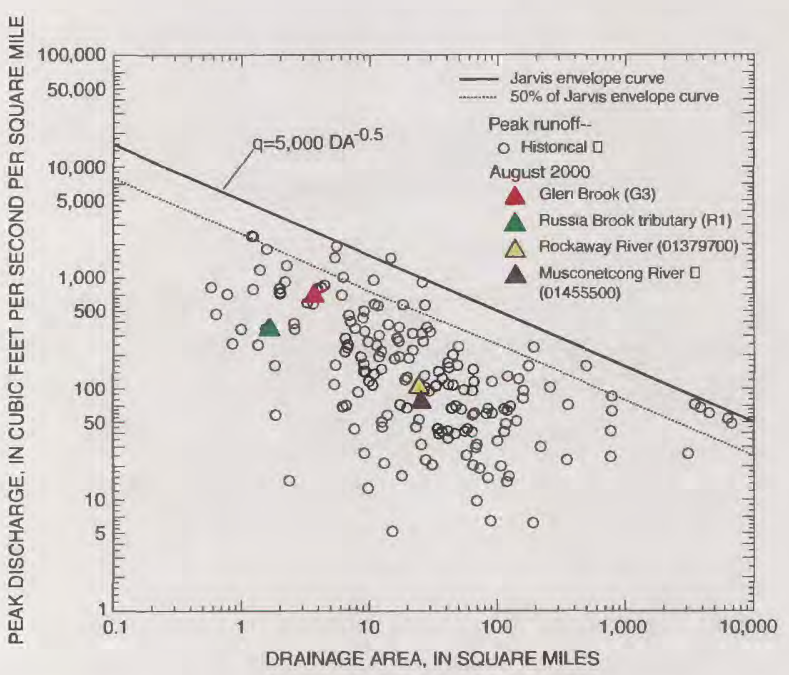

Figure 5. Historical peak unit-runoff values at selected U.S. Geological Survey streamflow-gaging stations in northwestern New Jersey and the four highest peak unitrunoff values measured during August 12-14, 2000. (DA, drainage area; q, peak flow per square mile)

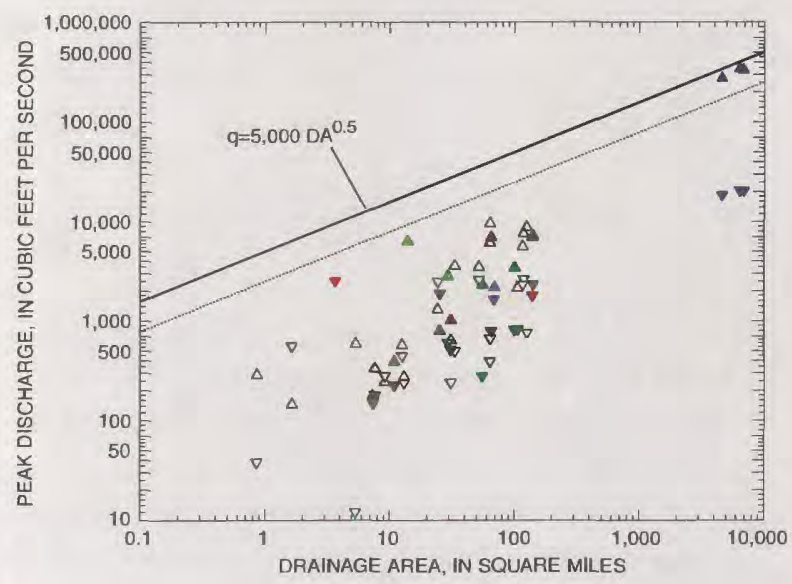

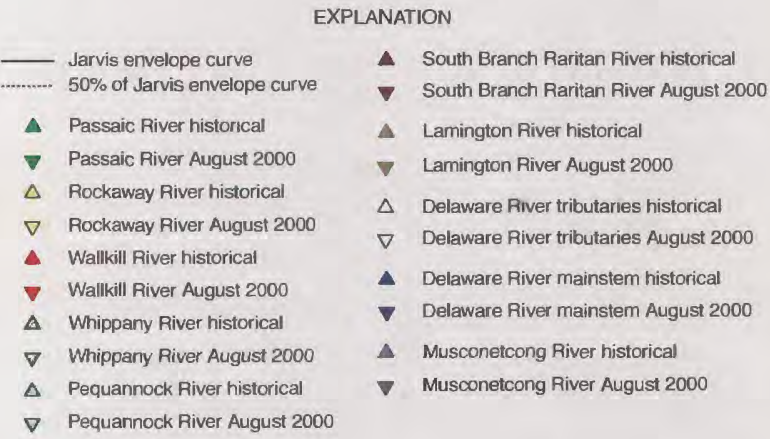

Figure 6. Historical peak runoff values at selected U.S. Geological Survey streamflow-gaging stations in northwestern New Jersey and peak runoff values during August 12-14, 2000. (DA, drainage area; q, peak flow in cubic feet per second) 


\section{Records Set at Established U.S. Geological Survey Gaging Stations}

Peak flows and stages at 13 of the 35 USGS gaging stations in northwestern New Jersey that experienced greater than a 2-year flood during August 12-15, 2000, are summarized in table 2.

The peak stages at 5 of the 35 gaging stations were the highest of record. Three of these gaging stations are in the Passaic River Basin and two are in the Delaware River Basin. The gaging stations in the Passaic River Basin are (1) Russia Brook tributary at Milton, N.J. (01379630), (2) Rockaway River at Berkshire Valley, N.J. (01379700), and (3) Green Pond Brook below Picatinny Lake at Picatinny Arsenal, N.J. (01379780). The gaging stations in the Delaware River Basin are Lake Hopatcong at Landing, N.J. (01455400) and Musconetcong River at outlet of Lake Hopatcong, N.J. (01455500). These gaging stations receive runoff from areas that received 10 or more inches of rain during August 11-14. The peak unit runoff and peak flow at USGS gaging stations occurred from August 12 to 15,2000 , and are compared with those of historical floods in figures 5 and 6, respectively.

The peak flow at Russia Brook tributary at Milton was the highest recorded at that site. This gage, which receives runoff from an area of 1.64 $\mathrm{mi}^{2}$ in Jefferson Township, is near the rain gage that recorded the highest rainfall during this storm. Russia Brook tributary drains a mountainous area and has steep slopes in its headwaters. A few small ponds are present along the stream in the more level terrain within 1 mi upstream of the site. Highwater marks were flagged along a $180-\mathrm{ft}$ section of stream beginning $50 \mathrm{ft}$ below the gage house and an indirect measurement of peak flow was computed. A peak flow of $650 \mathrm{ft}^{3} / \mathrm{s}$, or $396 \mathrm{ft}^{3} / \mathrm{s} /$ $\mathrm{mi}^{2}$, was calculated (table 2). Flow data for this gaging station are insufficient to compute floodfrequency statistics. The peak flow exceeded the 500-year recurrence-interval flow at the gage as defined by flood elevations predicted in the FEMA flood-insurance study for streams in Jefferson Township (Federal Emergency Management Agency, 1983a).

The gaging station on the Rockaway River at Berkshire Valley receives runoff from an area of
$24.4 \mathrm{mi}^{2}$. The drainage area includes Russia Brook tributary. The peak flow at the gaging station set a new record of $2,500 \mathrm{ft}^{3} / \mathrm{s}$, yielding a peak runoff of $102.5 \mathrm{ft}^{3} / \mathrm{s} / \mathrm{mi}^{2}$. The peaks recorded at two other sites farther downstream on the Rockaway River were less than historical peaks; runoff from the headwaters of the basin was attenuated by the time it reached the downstream sites.

A new record peak flow of $284 \mathrm{ft}^{3} / \mathrm{s}$ from a 9.16- $\mathrm{mi}^{2}$ area was recorded at the gaging station at Green Pond Brook below Picatinny Lake at Picatinny Arsenal (01379780), yielding $31.0 \mathrm{ft}^{3} / \mathrm{s} /$ $\mathrm{mi}^{2}$ (table 2). Peak runoff per square mile at the three downstream gaging stations along Green Pond Brook increased with drainage area. Unlike the larger Rockaway River Basin, the entire Green Pond Brook Basin was in the area of heavy rainfall and received an estimated 5 to $10 \mathrm{in}$. The other two gaging stations on Green Pond Brook (01379773 and 01379790) had record peaks in April 1984, before gaging station 01379780 was established. The flood peak at site 01379790 was the highest since 1984 , but the peak at 01379773 , the most upstream gaging station, only was the fifth highest since 1984.

A new record high stage (water surface) was set at Lake Hopatcong at Landing (01455400). The stage was $11.80 \mathrm{ft}, 1.25 \mathrm{ft}$ higher than the previous record high of $10.55 \mathrm{ft}$ on August 19, 1955. A new record peak flow was recorded at the gaging station on the Musconetcong River at the outlet of Lake Hopatcong ( 01455500$)$. Flow at this gaging station reached $1,900 \mathrm{ft}^{3} / \mathrm{s}$, resulting in a peak runoff of $75.1 \mathrm{ft}^{3} / \mathrm{s} / \mathrm{mi}^{2}$ from a $25.3-\mathrm{mi}^{2}$ area.

The peak flows at the two gaging stations on the Musconetcong River downstream from Lake Hopatcong were attenuated as runoff moved downstream from its source (fig. 4) and, as a result, were less than the historical peaks. The Musconetcong River near Hackettstown gaging station $(01456000)$ recorded the third highest peak in 75 years of record. Only the peak caused by Hurricanes Connie and Diane in August 1955 and a peak in January 1979 were higher. The peak flow at Musconetcong River near Bloomsbury (01457000), near the river's mouth, was not considered an extreme event. Higher peaks have been recorded in 27 of the 81 years of record at the gaging station. 


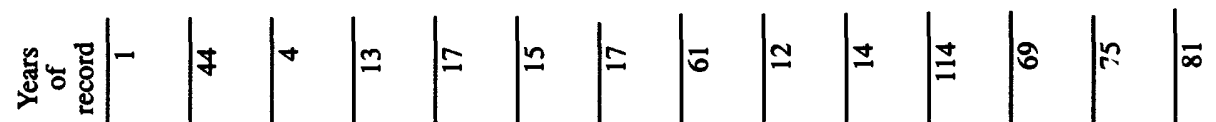

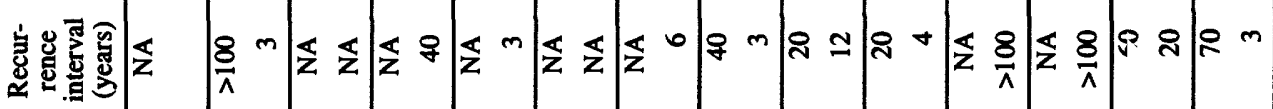

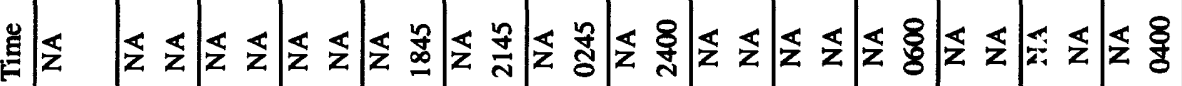

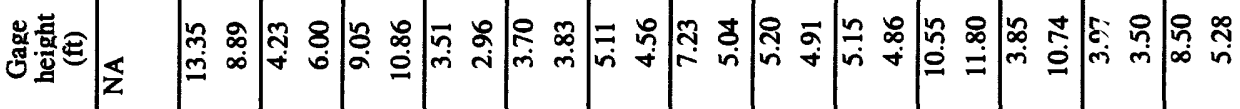

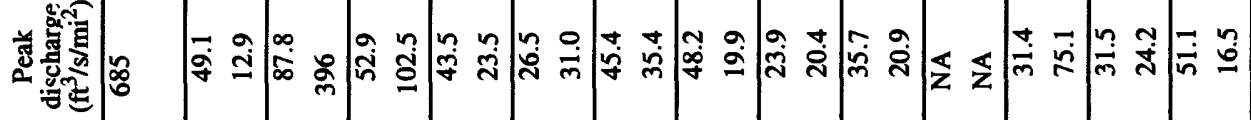

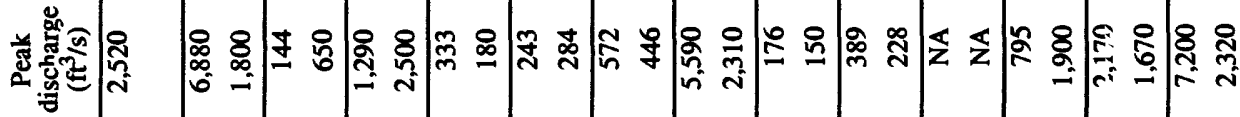

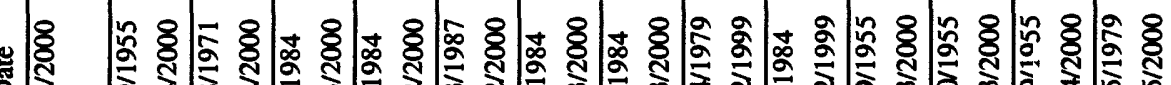

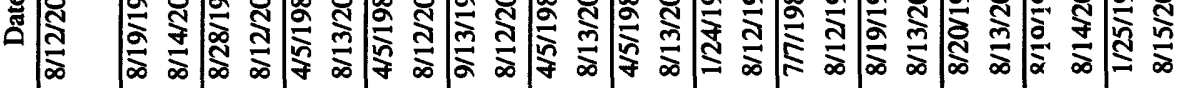

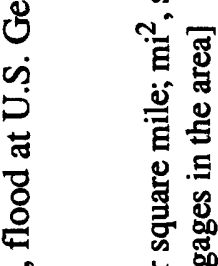
8 (5) 궁 $\pm \quad 8=$

ป

竞

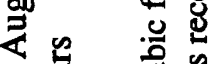

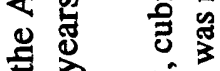

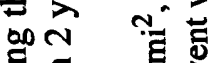
है 年 要部言

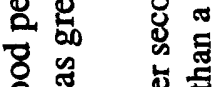
일

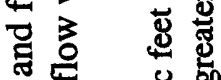
要

西 क्ष (2)

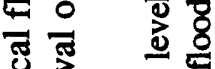
政 这星

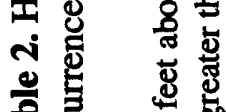
商赛

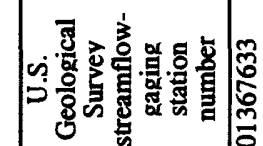

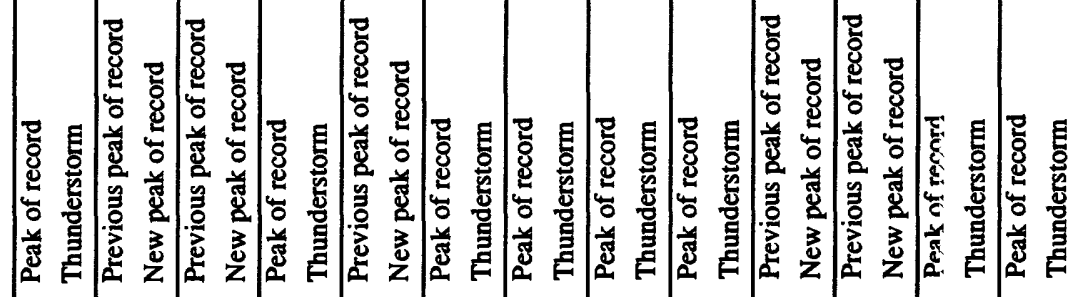

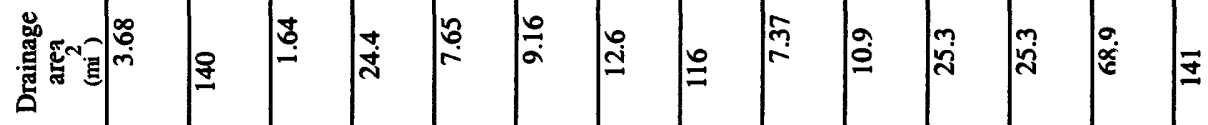

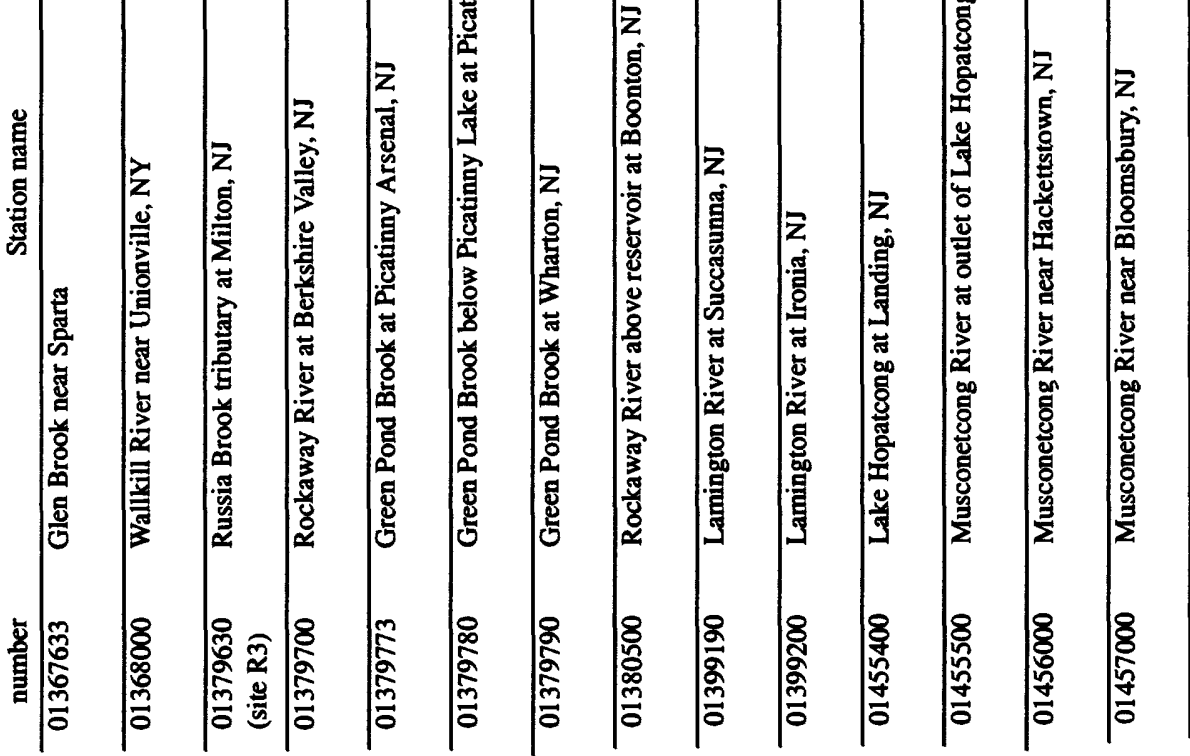




\section{Peak Stages at Sparta Flood Study Sites}

As part of this study, peak flood stages at 21 stream sites along the Wallkill River, Glen Brook, and Russia Brook tributary were documented (fig. 4). Sites were selected along the stream reaches known to have flood damage, in areas where there are no active USGS gaging stations to record the peak stage. Russia Brook tributary at Milton (01379630) and Wallkill River near Unionville $(01368000)$ are the two sites chosen at inactive gaging stations.

High-water marks were flagged at each site and the marks were surveyed to obtain peak stage (water-surface) elevations. High-water marks were surveyed from established benchmarks with known elevation. Nineteen of the sites are located at bridges. A standard was set for the number and location of marks to be flagged at these sites. At least four high-water marks were flagged, if possible. High-water marks were rated subjectively by field personnel as excellend, good, fair, or poor, according to guidelines in Benson and Dalrymple (1967). The best marks on both the left and right banks on both the upstream and downstream sides of the bridge were located. The two sites not located at a bridge are the Russia Brook tributary site (R1), located at a discontinued USGS gaging station, and Glen Brook near Sparta (G3). Site G3 was established in Sparta Glen along a section of the stream best suited for the indirect measurement of peak flow.

Peak flood elevations at each site are listed in table 3. The elevations listed for the August 1214,2000 , flood are average elevations calculated from marks downstream from the bridge at 18 sites. The peak elevation at site G3 is from the mean (water-surface) elevation at cross-section 2 in the middle of the slope-area measurement reach. The peak listed at site $\mathrm{R} 1$ is at the discontinued gaging station upstream from the weir. The peak elevation listed for site W16 is from a mark on a crest-stage gage on the downstream side of the bridge, verified by high-water marks.

The two peak elevations listed in table 3 for site W1 are the peak at the surface of Lake Mohawk and the peak at the downstream side of the bridge on West Shore Trail. Only one highwater mark was found at each location. Tr 9 mark located downstream from the bridge is rated poor and the true elevation could have been as much as $1 \mathrm{ft}$ lower. This estimate is based on good marks at site $\mathrm{W} 2$, indicating a peak between the 50 - and 100-year recurrence intervals. There was $r$ flow over the dam at Lake Mohawk during the flood event. All the flow draining from the lake at the headwaters of the Wallkill River Basin wathrough a 2-ft-diameter black drain tile, as witnessed by a construction crew from the P\&H Construction Company. Storage in Lake Mohawk appears to have lowered the flood elevation at sites $\mathrm{W} 1$ and $\mathrm{W} 2$ to less than that of the 100-yerr flood.

Three peak elevations are listed $\mathrm{fc}$ - site W9. These are the peak on Franklin Pond, the peak on the reach between the dam and the brid re on Franklin Avenue, and the peak downstrearn from the bridge. The peak for site W16 is from a mark on the crest-stage gage at the discontinued USGS gaging station (01368000).

Peak water-surface elevations for the August 2000 flood were compared to flood-profile elevations from various FEMA flood-insurance studies (Federal Emergency Management Agency, 1983a, 1983b, 1983c, 1983d, 1984a, 1984b) and USGS gaging stations where available. FEMA flood-insurance studies have been completed for each of the municipalities in which a site is located. Water-surface elevations for 10-, 50-, 100-, and 500-year flood frequencies are listed in tat 1 e 3. These elevations were obtained from flood profiles published in FEMA flood-insurance repor's. Water-surface elevations at various flood frequencies are available for 18 of the 21 sites. Es'imates of flood elevations are not available for Glen Brook in Sparta Township because no floorinsurance studies were conducted along the stream. Flood-frequency statistics for the Wallkill River near Unionville, N.Y. $(01368000$, site W16), are available from peak-streamflow data. The watersurface elevation of the 10-year flood was derived from a rating curve of discharges as a function of stage that was developed for the site (table 3 ).

Flood elevations at sites on Russia Brook tributary and the Wallkill River generally equaled or exceeded the 500-year flood elevations 


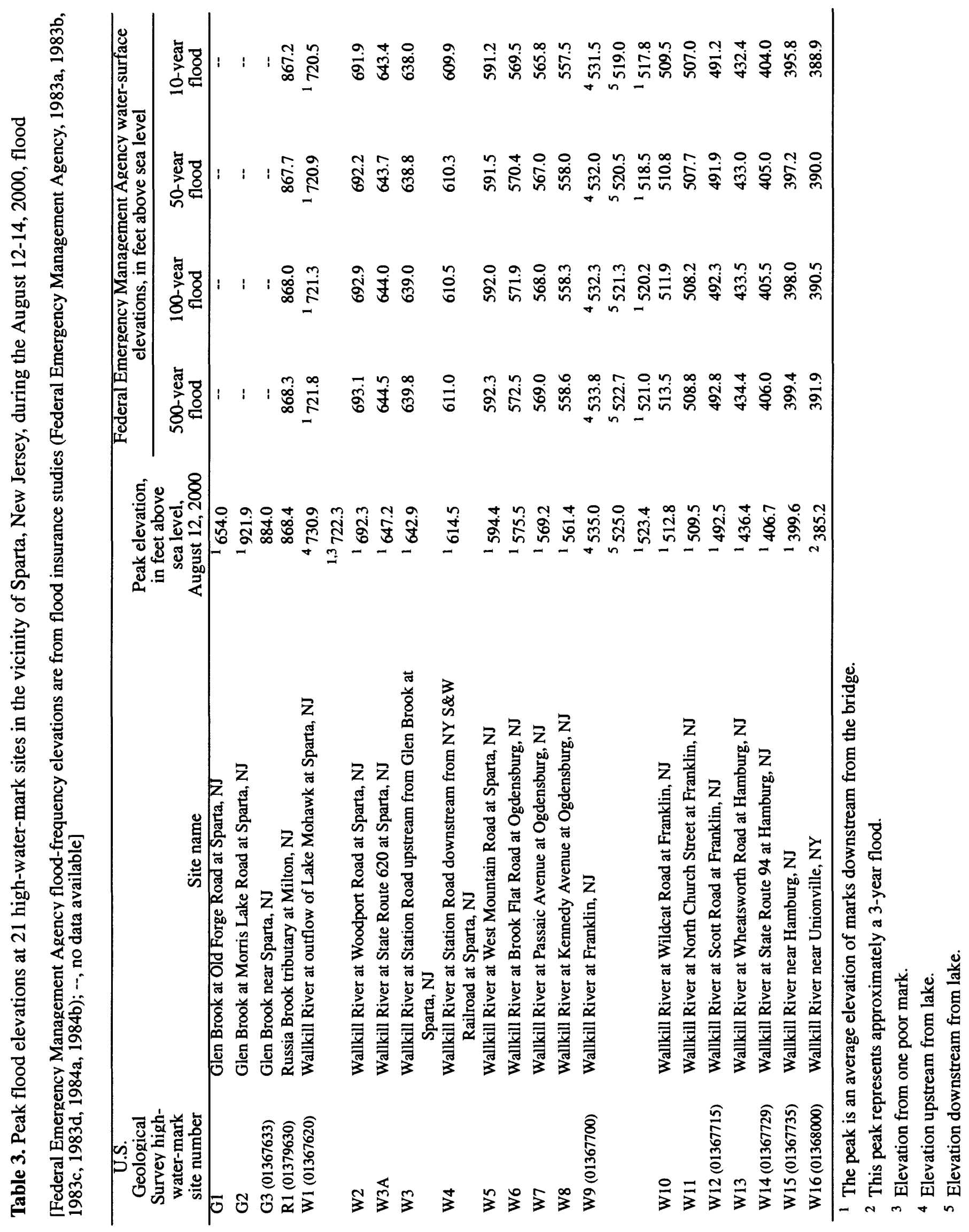


published in the FEMA flood-insurance reports (Federal Emergency Management Agency, 1983a, 1983b, 1983c, 1983d, 1984a, 1984b). Peak-flood elevations exceeded those of the 500-year flood at sites R1, W1, W3, W3a, W4, W5, W6, W7, W8, W9, W11, W13, W14, and W15. Peak-flood elevations equaled or exceeded those of the 100-year flood at sites W10 and W12. The peak at site W2 exceeded that of the 50-year flood. The peak water-surface elevation at site W16 was approximately equal to that of a 3-year flood.

\section{Peak Flows at Sparta Flood Study Sites}

Indirect measurements of peak flow were computed at two sites. The slope-area indirect method of computing discharge as described by Dalrymple and Benson (1967) was used to determine peak flow at Russia Brook near Milton (site R1) and at Glen Brook near Sparta (site G3). A suitable stream reach with a sufficient number of high-water marks was located at each site.

Glen Brook near Sparta (site G3) is located in Sparta Glen, 0.3 mi downstream from Morris Lake, approximately 1.3 mi northeast of Sparta. Some of the worst damage from this flood occurred along Glen Brook. All three major bridges crossing this stream were washed out, stranding residents in some neighborhoods. A peak flow of $2,520 \mathrm{ft}^{3} / \mathrm{s}$ through the stream reach was computed by means of the slope-area method. The drainage area at the downstream end of the 200-ft reach is $3.68 \mathrm{mi}^{2}$; therefore, peak runoff was 685 $\mathrm{ft}^{3} / \mathrm{s} / \mathrm{mi}^{2}$. This value is the highest runoff recorded by the USGS at any site during this flood (fig. 5).

Russia Brook tributary near Milton (site R1) is located at the site of the discontinued USGS gaging station. High-water marks were flagged and an indirect measurement of peak flow along a 180$\mathrm{ft}$ reach of stream beginning $50 \mathrm{ft}$ below the gage house was computed. A peak flow of $650 \mathrm{ft}^{3} / \mathrm{s}$ was calculated with the slope-area indirect method (table 2); therefore, peak runoff was $396 \mathrm{ft}^{3} / \mathrm{s} / \mathrm{mi}^{2}$. This value is the second highest runoff computed by the USGS for this event (fig. 5).

\section{FLOOD FREQUENCY}

Flood-frequency statistics are available for 25 of the 35 established USGS gaging stations in northwestern New Jersey. Thirteen of the 25 sites experienced a flood with greater than a 2-year recurrence interval as a result of the August 11-14, 2000 , storm (table 2). Flood frequencies at the USGS gaging stations and at the Sparta flondstudy sites are presented in figure 3. Peak flows resulting from this storm were compared to historical flood peaks and flood-frequency statistics at these sites. Peaks at the gage on Lake Hopa ${ }^{+}$ong and the Musconetcong River gage at the outlet of Lake Hopatcong exceeded those of a 100-ypar flood. At a gage farther downstream, Musconetcong River at Hackettstown, a peak equal to that of a 20-year recurrence-interval flood was recorded. At the gage farther downstream at Bloomsb'rry, near the mouth of the Musconetcong River, the recorded peak flow was less than that of the 3-year flood. Flow attenuation along the Musconet? ong River reflects the limited areal extent of the greatest rainfall in the headwaters of the basin. Flow also was attenuated at downstream sities on the Wallkill and Rockaway Rivers.

Flood peaks along the Wallkill River at most locations from Sparta downstream to Hamburg equaled or exceeded those of the 500year flood. A 500 -year flood has only a 0.2 -percent chance of occurring in any given year. Flood peaks at established USGS gaging stations in northwestern New Jersey varied from less than 2-year to 100 -year flood events, again reflecting the l'mited areal extent of the heavy rain. The flood peak on Lake Hopatcong and on the Musconetcong River

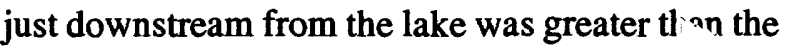
100-year flood. A 40-year flood was measured on the Rockaway River at Berkshire Valley, and the equivalent of a 12-year flood was recorded at the Lamington River at Succasunna. The gaging stations on Green Pond Brook experienced from 3year to 6-year flood events, which increased in magnitude with distance downstream. Flood peaks less than those of the 10-year flood were recorded at other USGS gaging stations in the area; peaks at many sites were less than those of the 2-year flood. 


\section{FLOOD DAMAGE}

About 2,700 homes and businesses in southeastern Sussex, western Morris, and parts of Warren and Hunterdon Counties along the Musconetcong River were flooded. Eight houses were destroyed and about 100 suffered major damage (N.J. Department of Environmental Protection, 2000). About 2,600 people in Morris, Sussex, and Hunterdon Counties were evacuated. The dams on Seneca Lake, Tomahawk Lake, Furnace Pond, and Edison Pond in Sussex County were completely destroyed. An additional 26 dams in Sussex and Morris Counties were damaged (N.J. Department of Environmental Protection, 2000). Three bridges were destroyed and eight others were damaged, or closed. Parts of 3 roads were washed away, 24 were damaged and many others were closed. Damage was estimated at $\$ 179$ million (National Weather Service, 2000). President Clinton declared Morris and Sussex Counties a Federal disaster area on August 16.

Flooding was most severe in the headwaters of the Wallkill River Basin. A state of emergency was declared on August 14 in Sparta, where properties along Glen Brook and other small tributaries to the Wallkill River had some of the worst damage from the flooding. Bridges in Sparta and Ogdensburg collapsed, leaving many motorists and entire neighborhoods stranded. All three major bridges that cross Glen Brook were washed out during the flood, stranding residents in some neighborhoods. Governor Whitman dispatched National Guard troops to help emergency crews reach flooded neighborhoods.

\section{SUMMARY}

Unusually large amounts of rain produced by a series of thunderstorms deluged parts of northwestern New Jersey during August 11-14, 2000. The rain was most intense from 9 a.m. to 3 p.m. on August 12, when precipitation rates nearly equaled the maximum recorded in the Mid-

Atlantic Region. The areal extent of total rainfall amounts greater than 3 in. was limited. Rainfall in northern New Jersey during August 11-14, 2000 , was greatest at rain gages within a 10-mi radius of Sparta Township in Sussex County. Parts of Jefferson Township received as much as 39 percent of the average annual precipitation for the region during this event. In the Sparta area, the storm produced four times as much rain than the longterm average for the month of August. F'soding was most severe along Glen Brook and other small tributaries to the Wallkill River. The U.S. Geological Survey (USGS), in cooperation with the Federal emergency Management Agency (FEMA), documented total rainfall amounts, resulting peak streamflows and stages, and flood frequencies at USGS gaging stations and selected sites.

Flood peaks recorded at USGS gaging stations on Lake Hopatcong, Musconetcong River, Green Pond Brook, Rockaway River, and Russia Brook tributary were the highest ever recorded. Flood peaks at 35 established USGS gaging stations in northwestern New Jersey ranged from less than 2-year to 100-year events, refle ting the limited areal extent of the greatest rainfall amounts and the large variation in rainfall across the area. Peak flow at the Russia Brook tributary station exceeded the 500-year recurrence-interval flow as defined by flood elevations predicted in the FEMA flood-insurance study for streams in Jefferson Township. Peak flows at the gaging stations on Lake Hopatcong and the Musconetcong River at the outlet of Lake Hopatcong exceeded those of a 100 -year flood. The Rockaway River at Berkshire Valley experienced a 40-year flood.

Peak flood (water surface) stages at 21 stream sites along the Wallkill River, Gle $\eta$ Brook, and Russia Brook tributary were documented. High-water marks were flagged at each site and the marks were surveyed to obtain peak (watersurface) elevations. Peak (water-surface) elevations for the August 2000 flood were compared to flood-profile elevations from various FEMA floodinsurance studies and USGS gaging stations where available. Flood elevations at sites on Russia Brook tributary and Wallkill River gener:lly equaled or exceeded the 500-year flood elevations published in the FEMA flood-insurance roports. As a result of the storage capacity of Lake Mohawk, peak flow at the outlet of the lake at the hoadwaters of the Wallkill River was less than that of a 100year flood. The peak (water-surface) elev'ation at the most downstream site on the Wallkill River, near Unionville, was approximately equal to that of a 3-year flood. 
Indirect measurements of peak flow were computed for two sites. Peak flow computed for Glen Brook near Sparta was $2,520 \mathrm{ft}^{3} / \mathrm{s}$ or $685 \mathrm{ft}^{3} / \mathrm{s} / \mathrm{mi}^{2}$. Peak flow computed for Russia Brook tributary near Milton was $650 \mathrm{ft}^{3} / \mathrm{s}$, or $396 \mathrm{ft}^{3} / \mathrm{s} / \mathrm{mi}^{2}$.

About 2,700 homes and businesses in western Morris, southeastern Sussex, and parts of Warren and Hunterdon Counties along the Musconetcong River were flooded and damaged. About 2,600 people in Morris, Sussex, and Hunterdon Counties were evacuated. Four dams in Sussex County failed completely and 26 dams in Morris and Sussex Counties were damaged. Three bridges were destroyed and eight others were damaged or closed; various roads were damaged, closed, or completely washed away. Total damage was estimated at $\$ 179$ million, and Morris and Sussex Counties were declared Federal disaster areas on August 16, 2000. 


\section{REFERENCES CITED}

Arcement, G.J., and Schneider, V.R., 1989, Guide for selecting Manning's roughness coefficients for natural channels and flood plains: U.S. Geological Survey WaterSupply Paper 2339, 38 p.

Barnes, H.H., 1967, Roughness characteristics of natural channels: U.S. Geological Survey Water-Supply Paper 1849, 213 p.

Benson, M.A., and Dalrymple, Tate, 1967, General field and office procedures for indirect discharge measurements: U.S. Geological Survey Techniques of Water-Resources Investigations, book 3, chap. A1, $30 \mathrm{p}$.

Dalrymple, Tate, and Benson, M.A., 1967, Measurement of peak discharge by the slope-area method: U.S. Geological Survey Techniques of Water-Resources Investigations, book 3, chap. A2, 12 p.

Federal Emergency Management Agency, 1983a, Flood insurance study, Township of Jefferson, Sussex County, New Jersey: Federal Emergency Management Agency, Federal Insurance Administration, January 1983, 23 p.

Federal Emergency Management Agency, 1983b, Flood insurance study, Township of Wantage, Sussex County, New Jersey: Federal Emergency Management Agency, Federal Insurance Administration, August 1983, 14 p.

Federal Emergency Management Agency, 1983c, Flood insurance study, Borough of Franklin, Sussex County, New Jersey: Federal Emergency Management Agency, Federal Insurance Administration, September 1983, 14 p.

Federal Emergency Management Agency, 1983d, Flood insurance study, Borough of Hamburg, Sussex County, New Jersey: Federal Emergency Management Agency, Federal Insurance Administration, September 1983, $14 \mathrm{p}$.
Federal Emergency Management Agenc.", 1984a, Flood insurance study, Borough of Ogdensburg, Sussex County, New Jersey: Federal Emergency Management Agency, Federal Insurance Administration, March 1984, 14 p.

Federal Emergency Management Agenc.', 1984b, Flood insurance study, Township of Sparta, Sussex County, New Jer:ey: Federal Emergency Management Agency, Federal Insurance Administration, April 1984, 17 p.

Fulford, J.M., 1994, User's guide to SAC, a computer program for computing discharge by the slope-area metl nd: U.S. Geological Survey Open-File Report 94-360, $31 \mathrm{p}$.

Jarrett, R.D., 1986, Evaluation of slope-area method for computing peak disc'harge, in Subitzky, Seymour, ed., Selectec' papers in the hydrologic sciences 1986: U.S. Geological Survey Water-Supply' Paper 2310, p. 13-24.

National Weather Service, 2000, Storm c'ata and unusual weather phenomena, August 2000, New Jersey Report. (Accersed May 29,2002 , on the World Wide We' at URL http://www4.ncdc.noaa.gov/cgi-win/ wwcgi.dll?wwevent ShowEvent 386665)

New Jersey Department of Environmental Protection, 2000, August 2000 storm report, New Jersey Department of Environmental Protection, Dam Safety Section. (Accessed March 12, 2701, on the World Wide Web at URL http:// www.state.nj.us/dep/nhr/engineering/ damsafety)

Thomas, D.M., 1964, Floods in New Jersey: Magnitude and frequency: U.S. Geological Survey Water Resources Circular 13, $145 \mathrm{p}$. 


\section{REFERENCES CITED--Continued}

U.S. Department of Commerce, 1958, Rainfall intensity-frequency regime: Technical Paper No. 29, Part 3--The Middle Atlantic Region: Washington, D.C., U.S.

Department of Commerce, Weather Bureau, July 1958, 20 p.

Weather Services International Corporation, 2000, Doppler radar image of total 24-hour precipitation in the northeastern United States. (Accessed August 13, 2000, on the World Wide Web at URL http:// www.intellicast.com/Local USLocalWide.asp?loc=kphl\&seg=LocalW eather\&prodgrp=HistoricWeather\&produc $\mathrm{t}=$ Precipitation \&prodna $\mathrm{v}=$ none) 
Appendix 1. Site description of and high-water marks at 21 selected stream sites, flood of August 11-14, 2000, Sparta, N.J. 


\section{SITE DESCRIPTION}

Site G1: Glen Brook at Old Forge Road at Sparta, N.J.

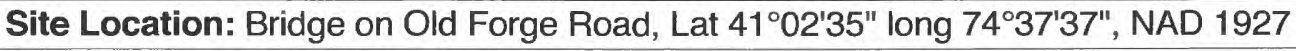

Sparta Township, Sussex County, New Jersey, Community 340535

Newton East USGS 7.5' Topographic Quadrangle

High-Water Marks: Four high-water marks were flagged: 3 mud lines and 1 seed line.

Photos and GPS readings were taken at each high-water mark.

Field notes are filed at USGS office in West Trenton, N.J.

Marks were flagged and photos taken by T.J. Reed and R.W. Edwards on Monday, September 11, 2000. Surveying was completed on November 1, 2000.

High-water-mark elevations were surveyed from benchmark T14.

Five additional photographs of the site were taken on September 20, 2000, after construction crews lowered the streambed elevation.

New State Route 15 and rerouted County Route 517 are shown on the map below but are not shown on the latest 1971 photorevised maps currently in publication.

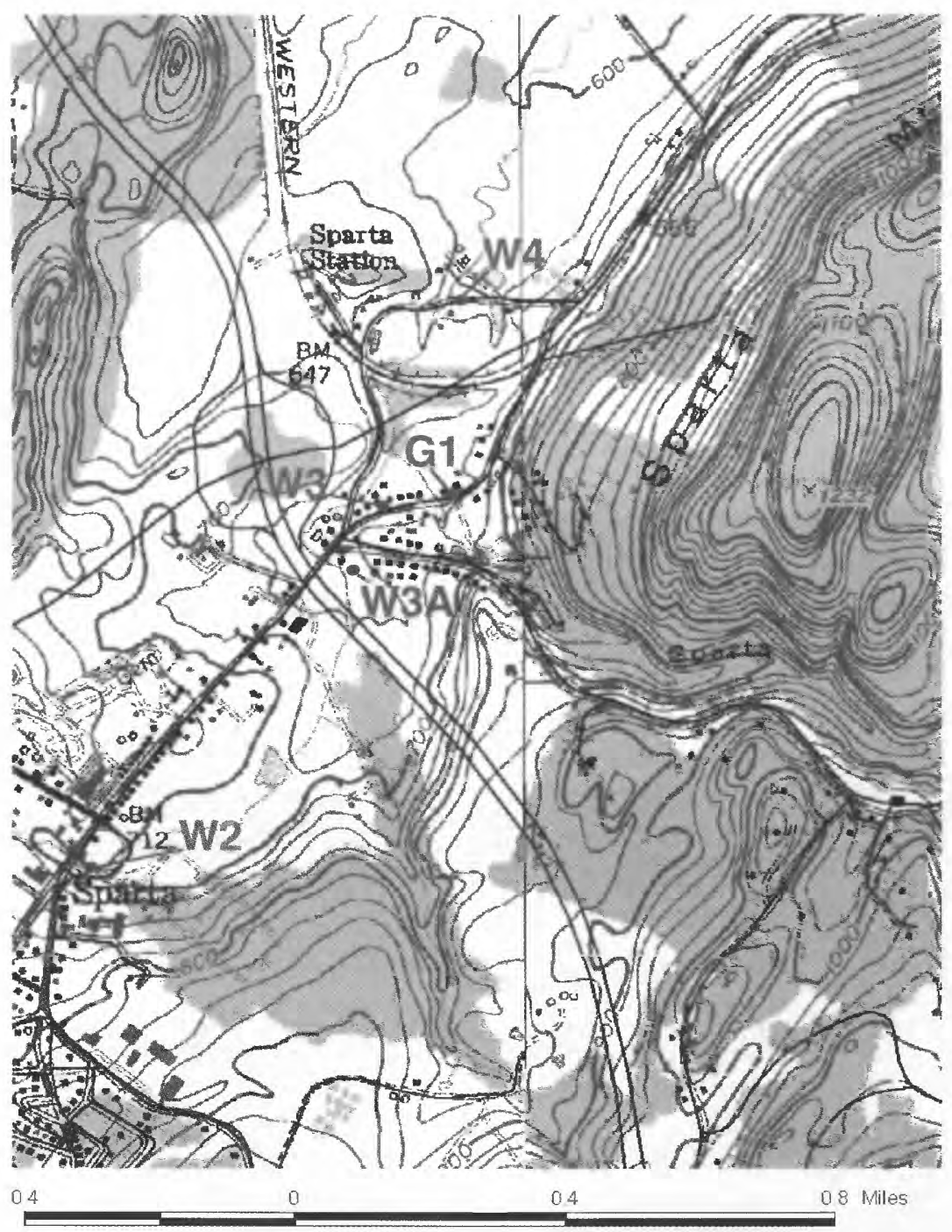

Newton East/Franklin quad map showing location of site G1, Glen Brook at Old Forge Road at Sparta, N.J. 
Site G1 Glen Brook at Old Forge Road at Sparta, N.J.

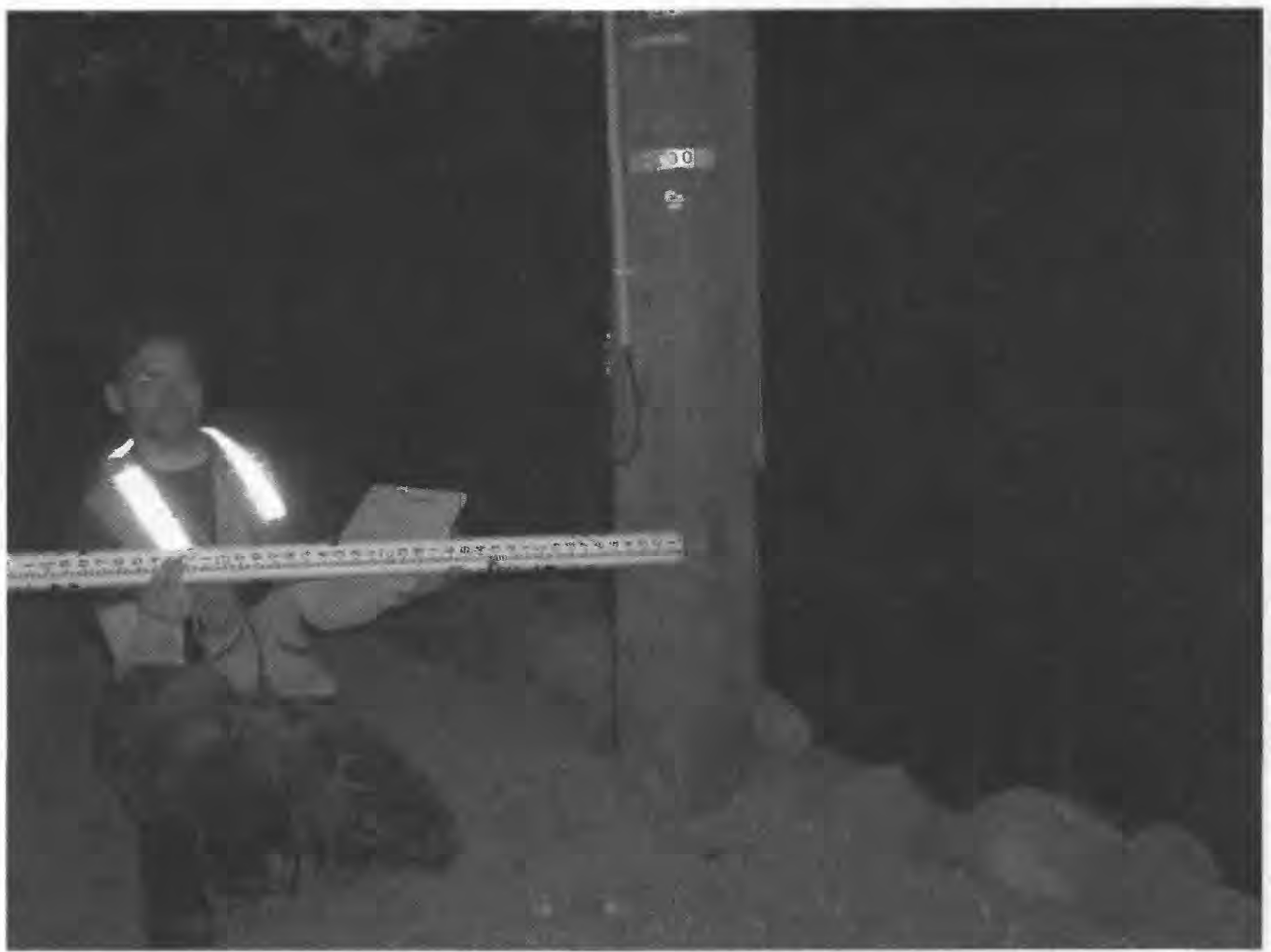

High-water mark G1.2 is a mud line on telephone pole LS NJ122ST S100, on the right bank, 5 feet upstream from bridge. Elevation is 658.6 feet above sea level.

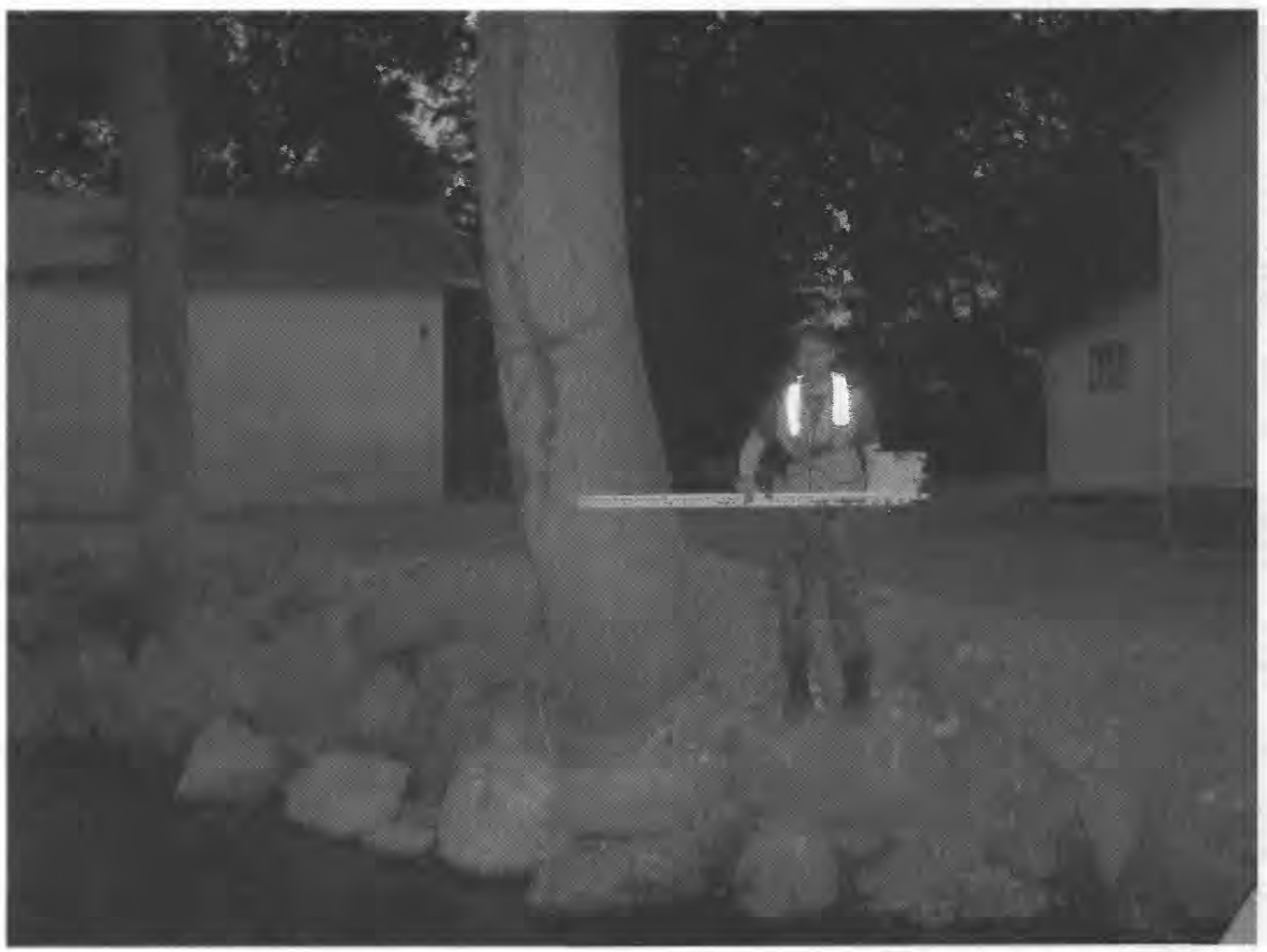

High-water mark G1.3 is a good mud line on 2.5-foot-diameter tree on the left bank, 20 feet upstream from bridge. Elevation is 658.5 feet above sea level. 
Site G1 Glen Brook at Old Forge Road at Sparta, N.J.

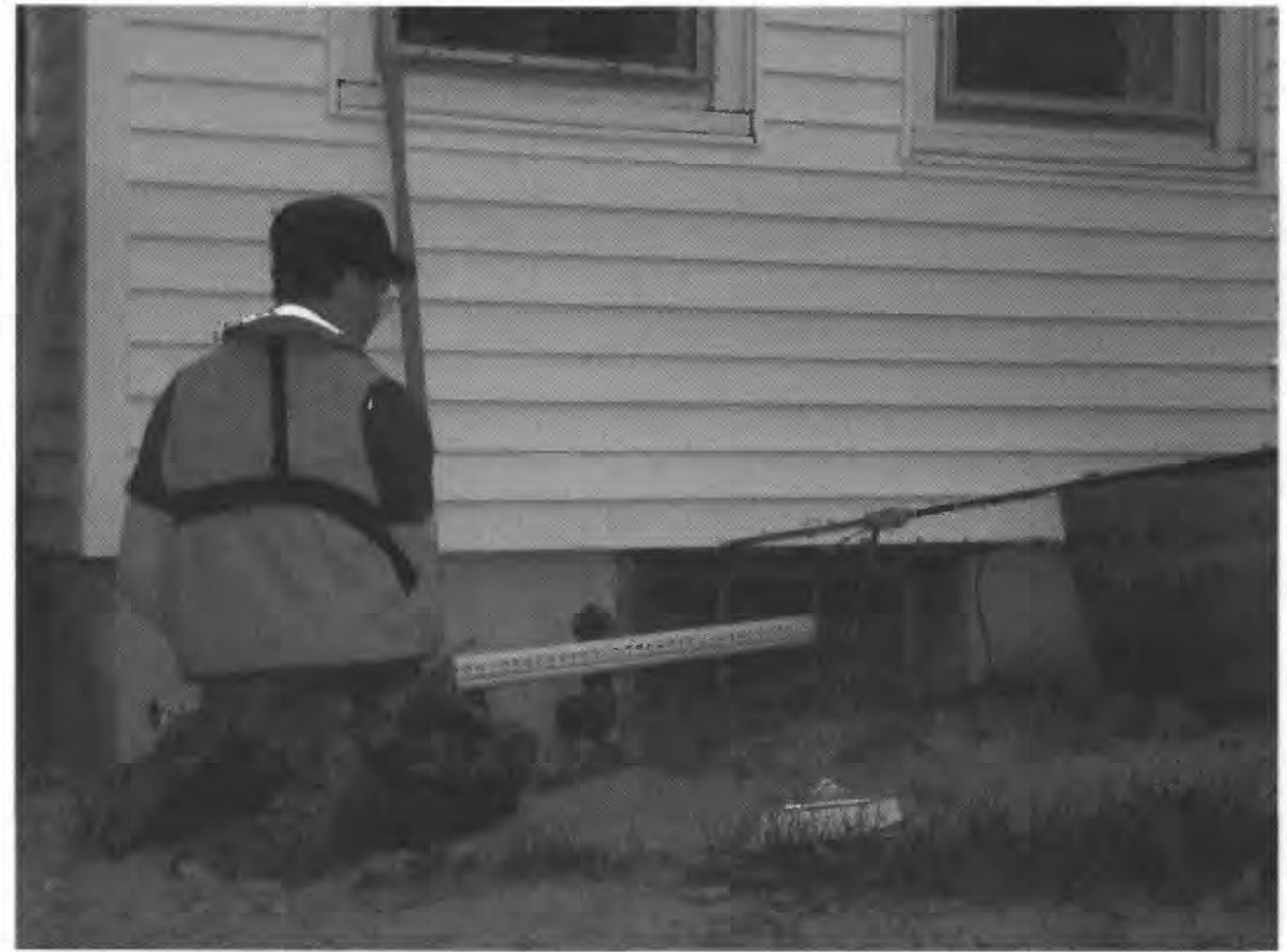

High-water mark G1.4 is a mud line on basement window, 40 feet downstream from bridge on the right bank. Elevation is 653.7 feet above sea level.

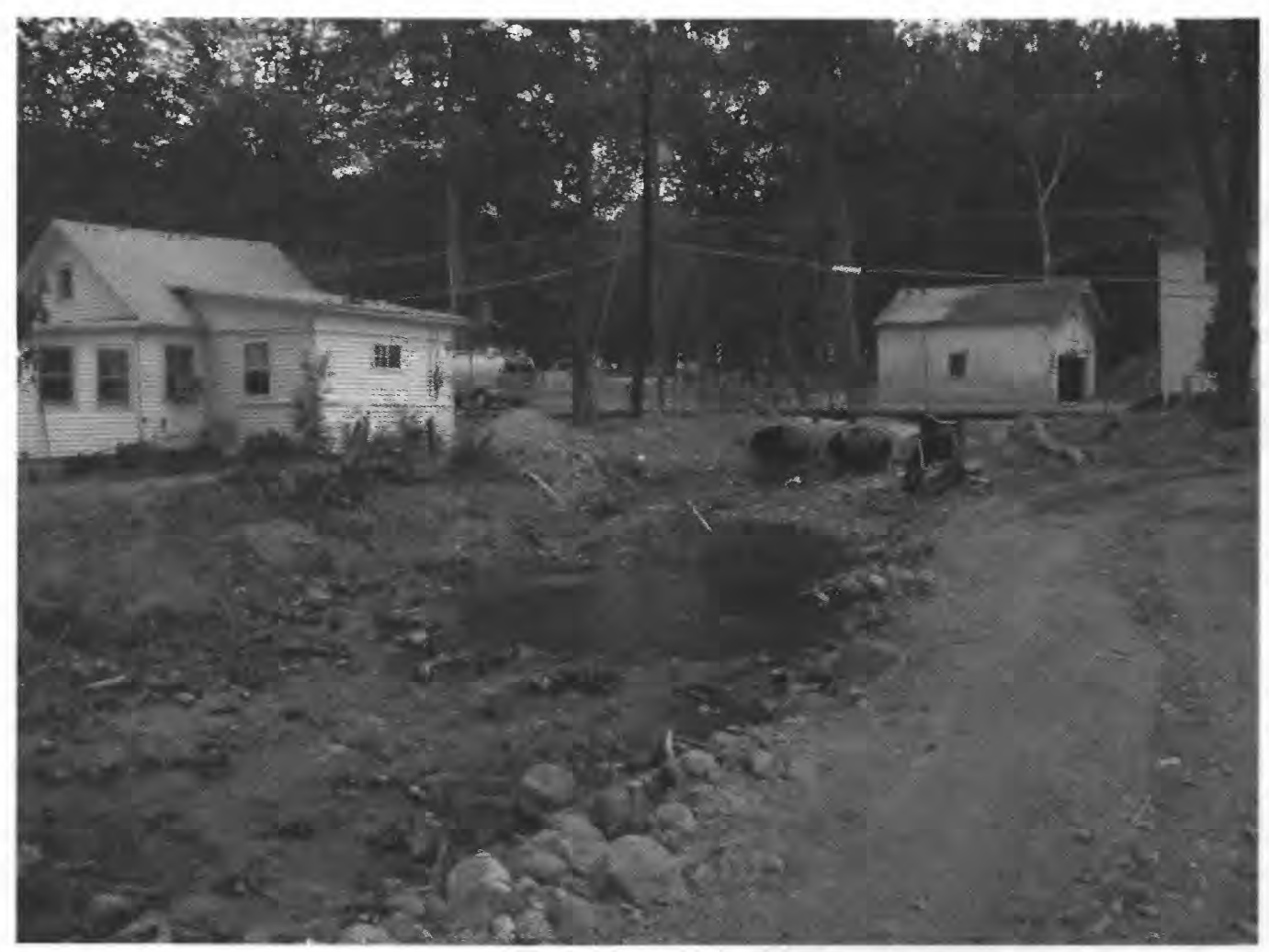

View, looking upstream, of temporary culvert used to replace bridge that washed out. This photograph was taken next to the tree on which high-water mark G1.1 was set. High-water mark G1.1 is a seed line on tree, 90 feet downstream from the bridge, on the left bank, 2 feet above the new streambed elevation, at elevation 658.5 feet above sea level. 
Site G1 Glen Brook at Old Forge Road at Sparta, N.J.

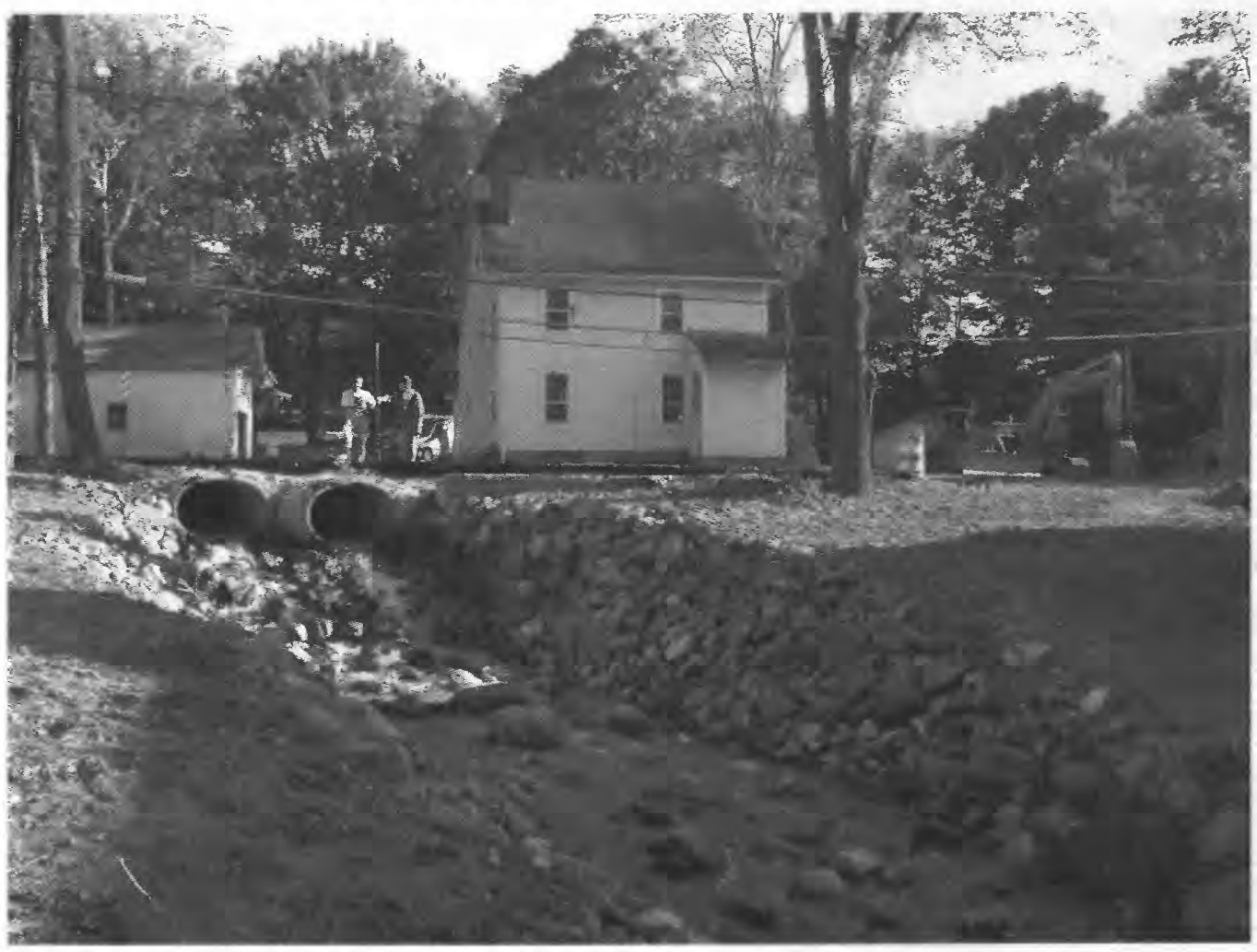

Photograph taken on September 20,2000; same view of Glen Brook as in the previous photograph taken on September 11, 2000, near high-water mark G1.1. Note that the channel has been modified (streambed has been lowered). 


\section{SITE DESCRIPTION}

Site G2: Glen Brook at Morris Lake Road at Sparta, N.J.

Site Location: Bridge on Morris Lake Road, Lat $41^{\circ} 02^{\prime} 20^{\prime \prime}$ long 74³6'32", NAD 1927

Sparta Township, Sussex County, New Jersey, Community 340535

Franklin USGS 7.5' Topographic Quadrangle

High-Water Marks: Four high-water marks flagged: 1 good debris line, 2 fair debris lines, and 1 fair seed line.

GPS readings were taken at each mark. Field notes are filed at USGS office in West Trenton, N.J.

Marks were flagged and photos taken by T.J. Reed and R.W. Edwards on Thursday,

September 14, 2000. Surveying was completed on November 1, 2000.

High-water-mark elevations were surveyed from benchmarks set at Newton Reservoir in February 1995 (Harold E. Pello \& Associates, Augusta, N.J., Morris Lake Hydrographic Survey, unpublished map, August 6,1996$)$. These benchmarks were set before filtration-plant construction began at the reservoir.

New State Route 15 and rerouted County Route 517 are shown on the map below but are not shown on the latest 1971 photorevised maps currently in publication.

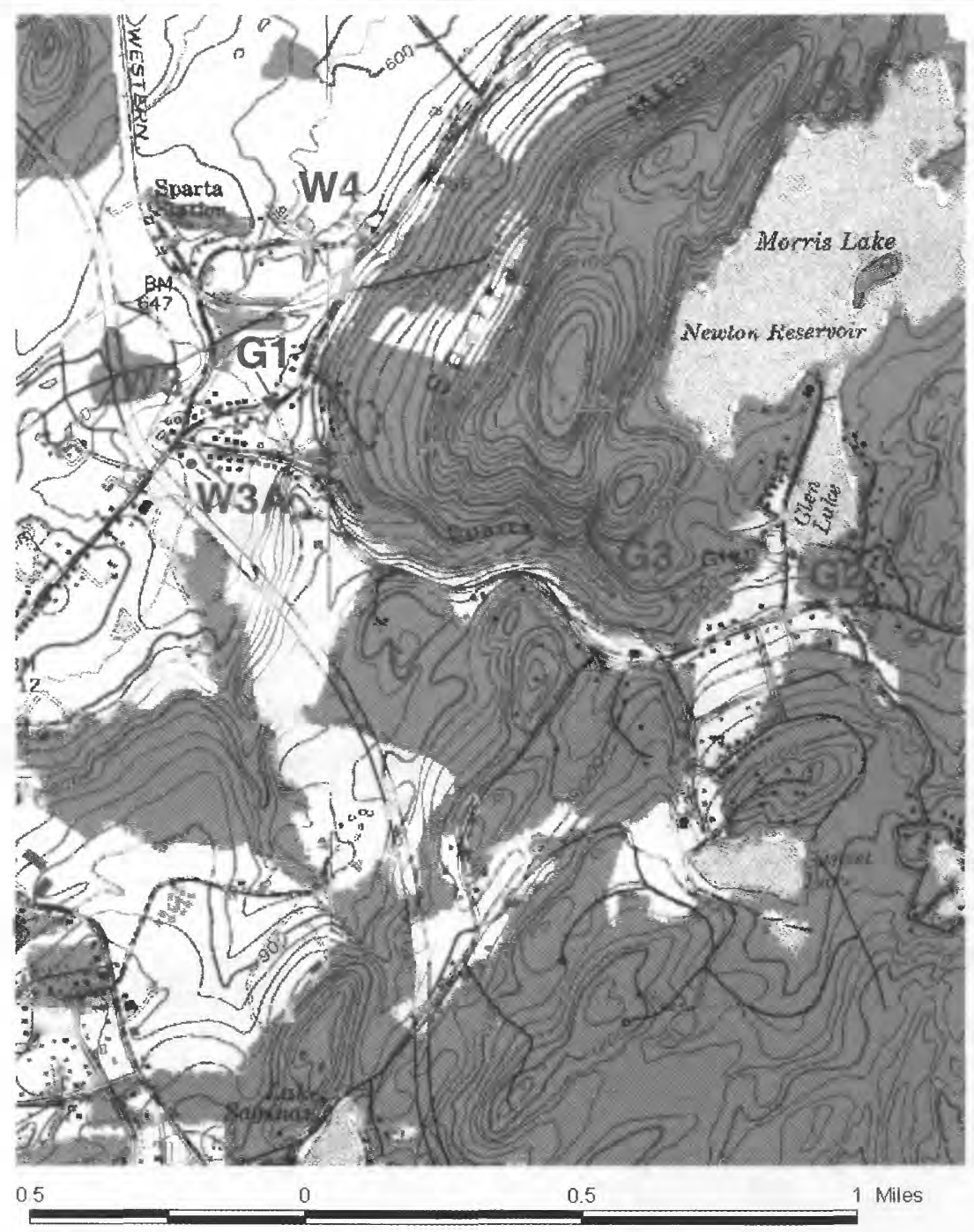

Newton East/Franklin quad map showing location of site G2, Glen Brook at Morris Lake Road at Sparta, N.J. 
Site G2 Glen Brook at Morris Lake Road at Sparta, N.J.

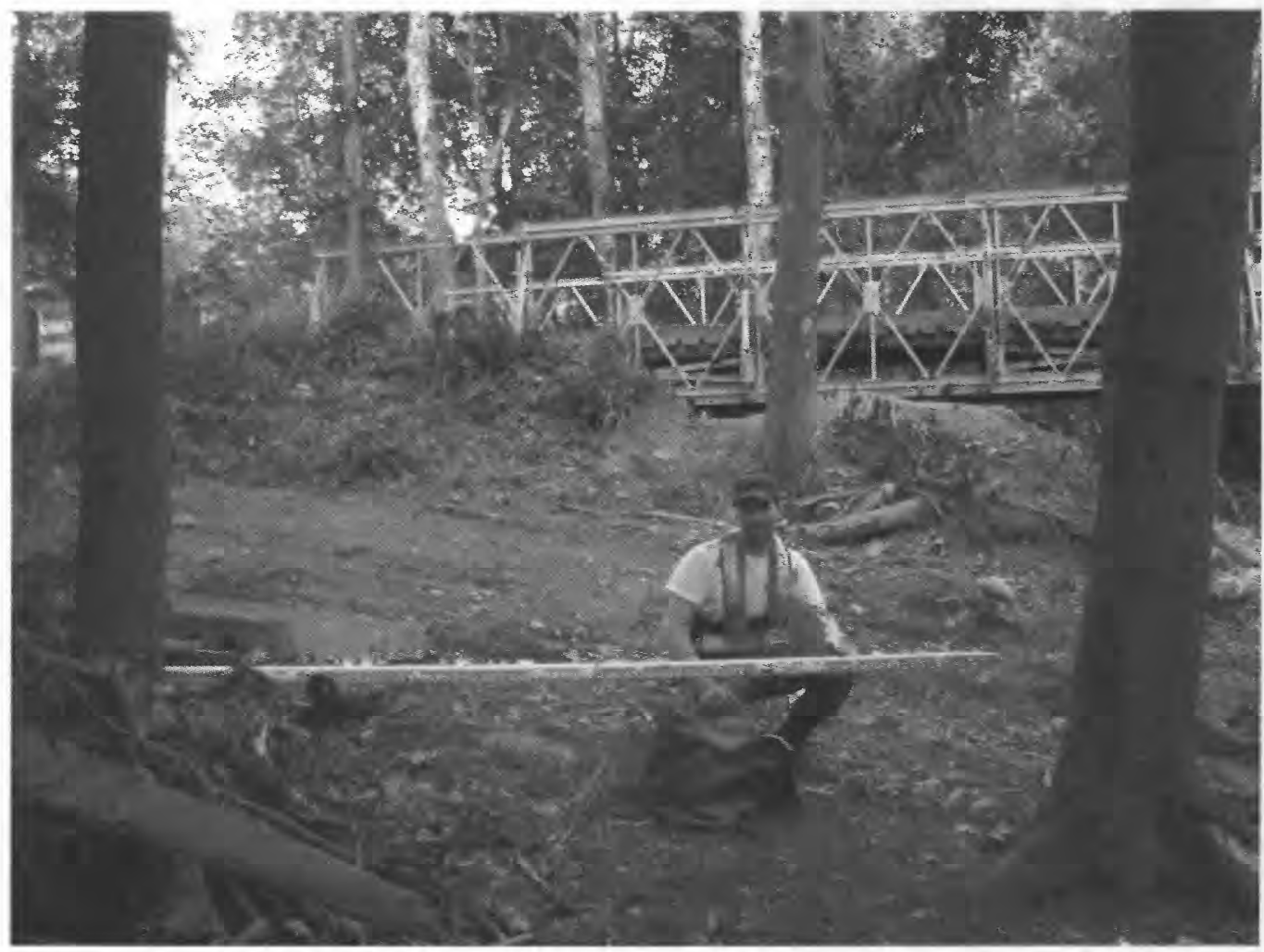

High-water mark G2.1 is a good debris line at base of 10-inch-diameter maple tree, on the right bank, 40 feet downstream from bridge and 0.2 feet above ground, at elevation 922.4 feet above sea level.

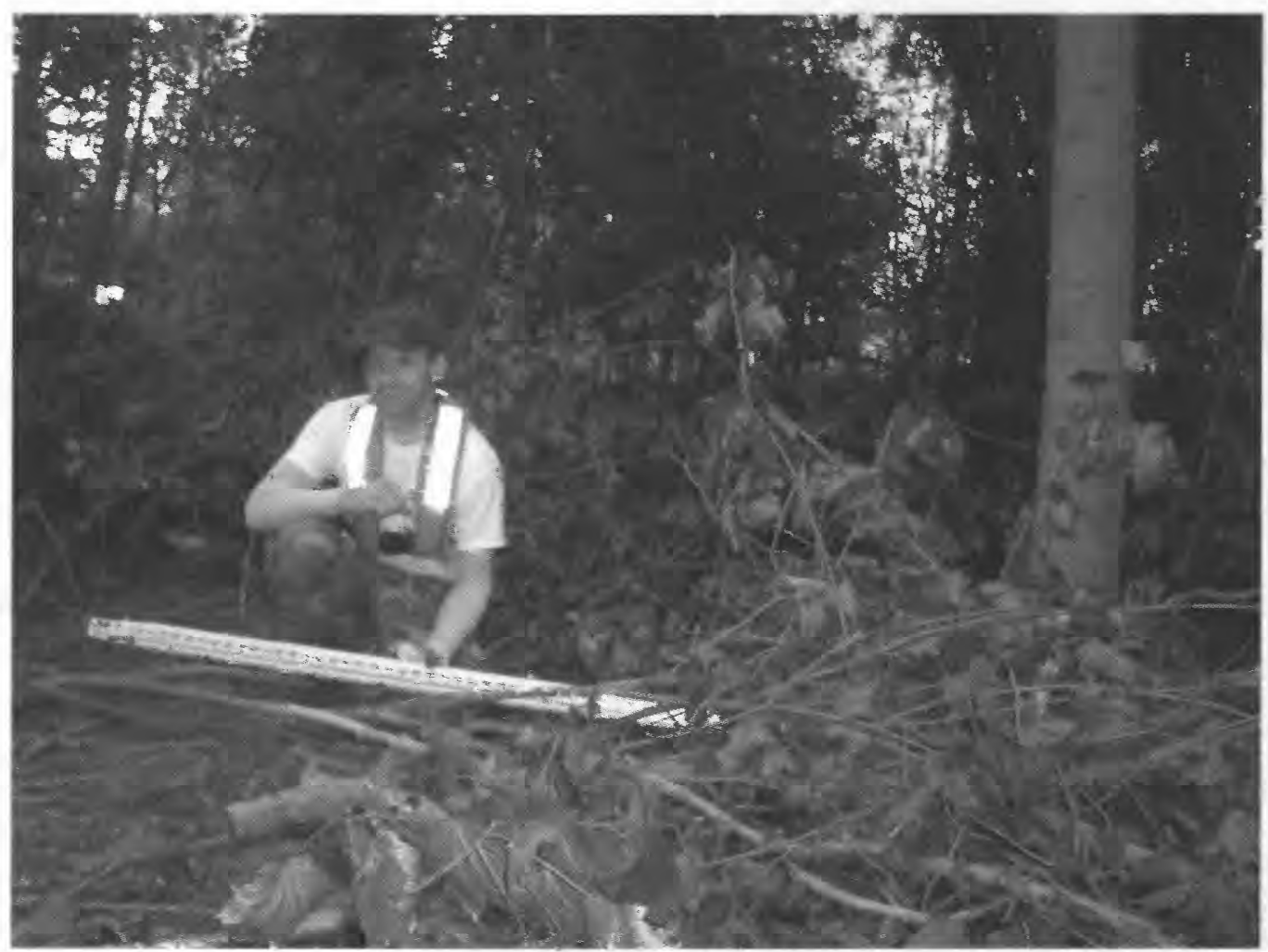

High-water mark G2.2 is a fair debris line at base of 7.0-inch-diameter tree on the left bank, 40 feet downstream from bridge and 1.0 foot above ground, at elevation 921.4 feet above sea level. 


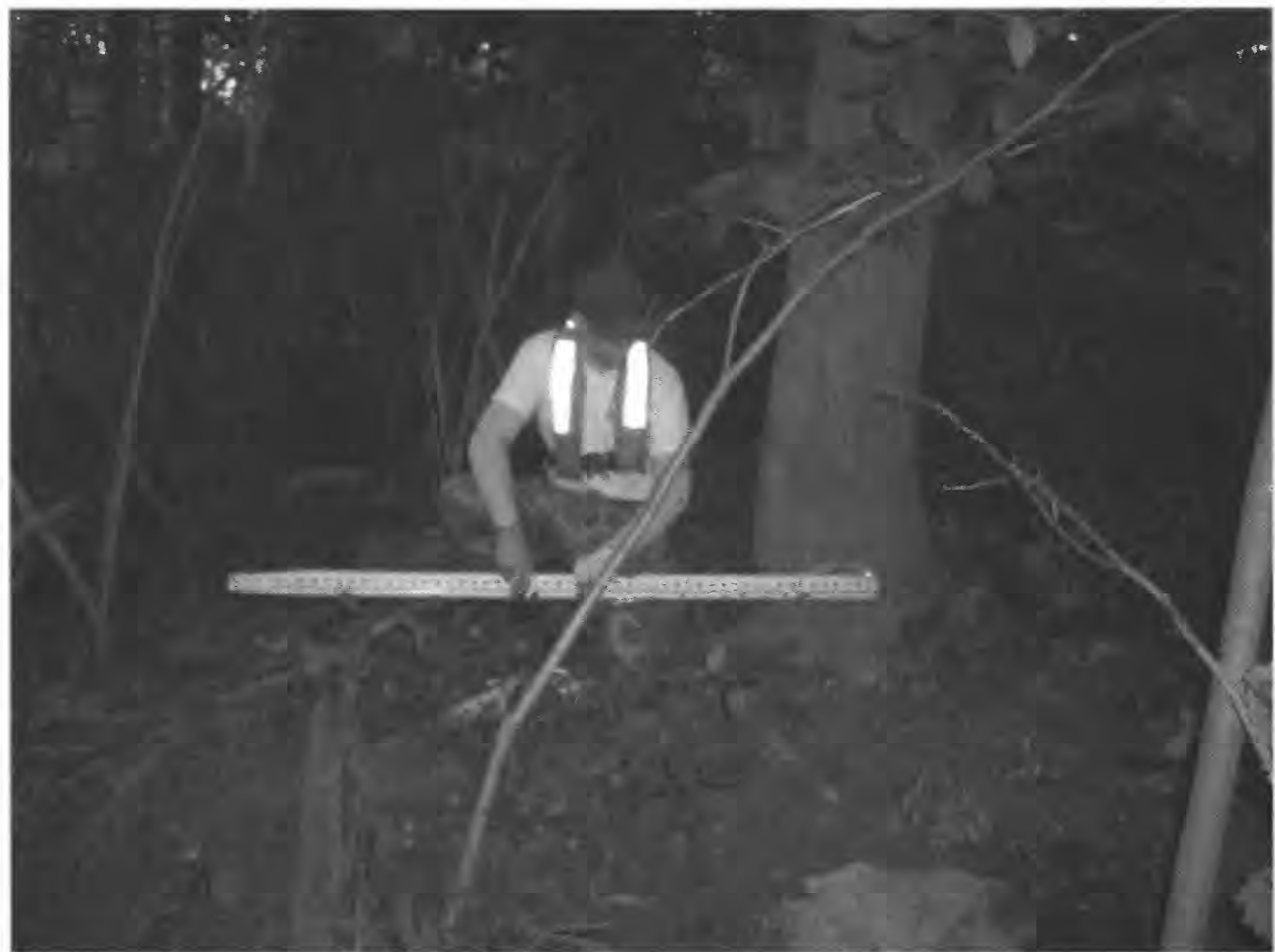

High-water mark G 2.3 is a fair debris line on 15-inch-diameter tree, 56 feet upstream from bridge on the left bank, and 0.7 feet above ground, at elevation 926.6 feet above sea level.

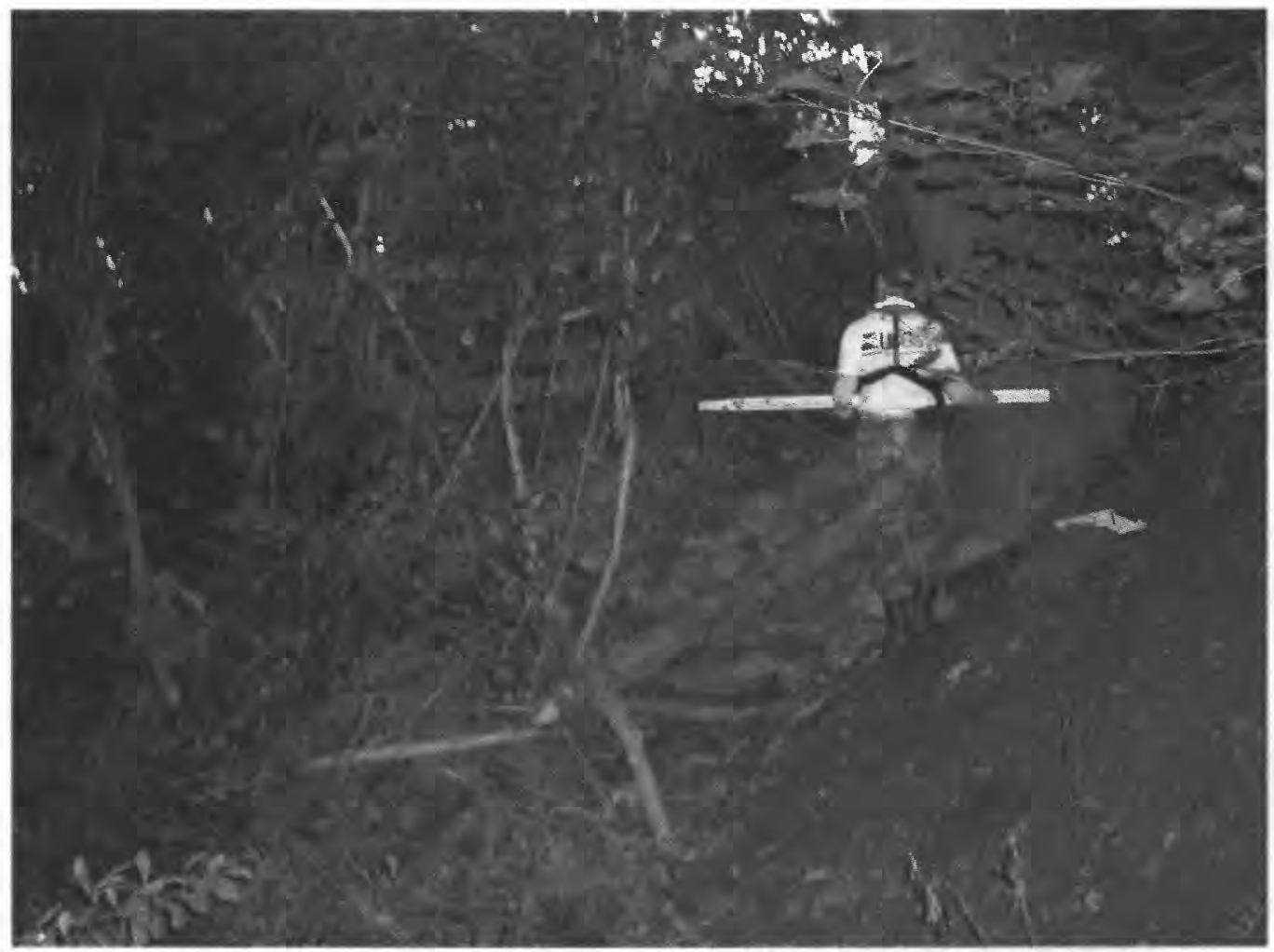

High-water mark G2.4 is a fair seed line on 30-inch-diameter tree, 10 feet upstream from bridge, on right bank, and 2.5 feet above the base of tree, at elevation 925.9 feet above sea level. 


\section{SITE DESCRIPTION}

Site G3: (USGS streamflow-gaging station 01367633): Glen Brook near Sparta, N.J.

Site Location: approximately 0.2 miles downstream from bridge on Morris Lake Road, Lat $41^{\circ} 02^{\prime} 16^{\prime \prime}$ long $74^{\circ} 36^{\prime} 47^{\prime \prime}$, NAD 1927. Drainage area: 3.68 square miles

Sparta Township, Sussex County, New Jersey, Community 340535

Franklin USGS 7.5' Topographic Quadrangle

High-Water Marks: 17 high-water marks (HWM's) flagged: good and fair debris and wash lines.

GPS readings were taken at some high-water marks. (Field notes are filed at USGS office in

West Trenton, N.J.)

Marks were flagged by D.A. Stedfast and R.G. Reiser on Monday, September 11, 2000. Marks surveyed to arbitrary datum for indirect measurement of flow by R.G. Reiser, R.W. Edwards, and G. Holzer on Monday, September 18, 2000. Photos were taken at the indirect-measurement site. Marks surveyed to sea level on November $8,2000, \mathrm{RM}$ is 882.09 feet above sea level.

See indirect-measurement notes for descriptions of reference mark RM1 and HWM's, filed at USGS office in West Trenton, N.J. Peak flow was $2,510 \mathrm{ft} / \mathrm{s}$.

High-water-mark elevations were surveyed from benchmarks set by Harold Pello \& Associates at Newton Reservoir in February 1995.

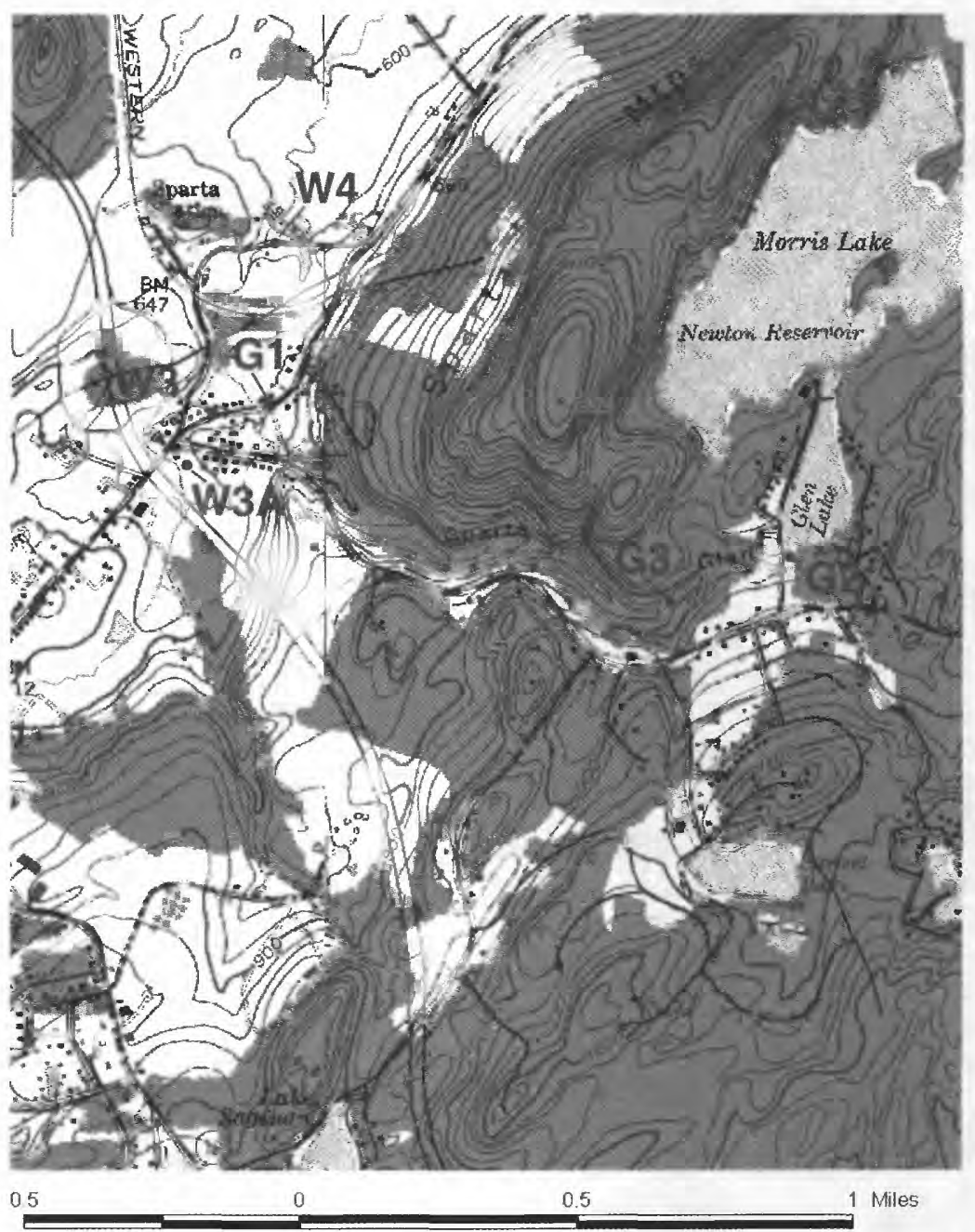

Newton East/Franklin quad map showing location of site G3 (01367633), Glen Brook at Morris Lake Road at Sparta, N.J. 
Site G3 (01367633), Glenn Brook near Sparta, N.J.

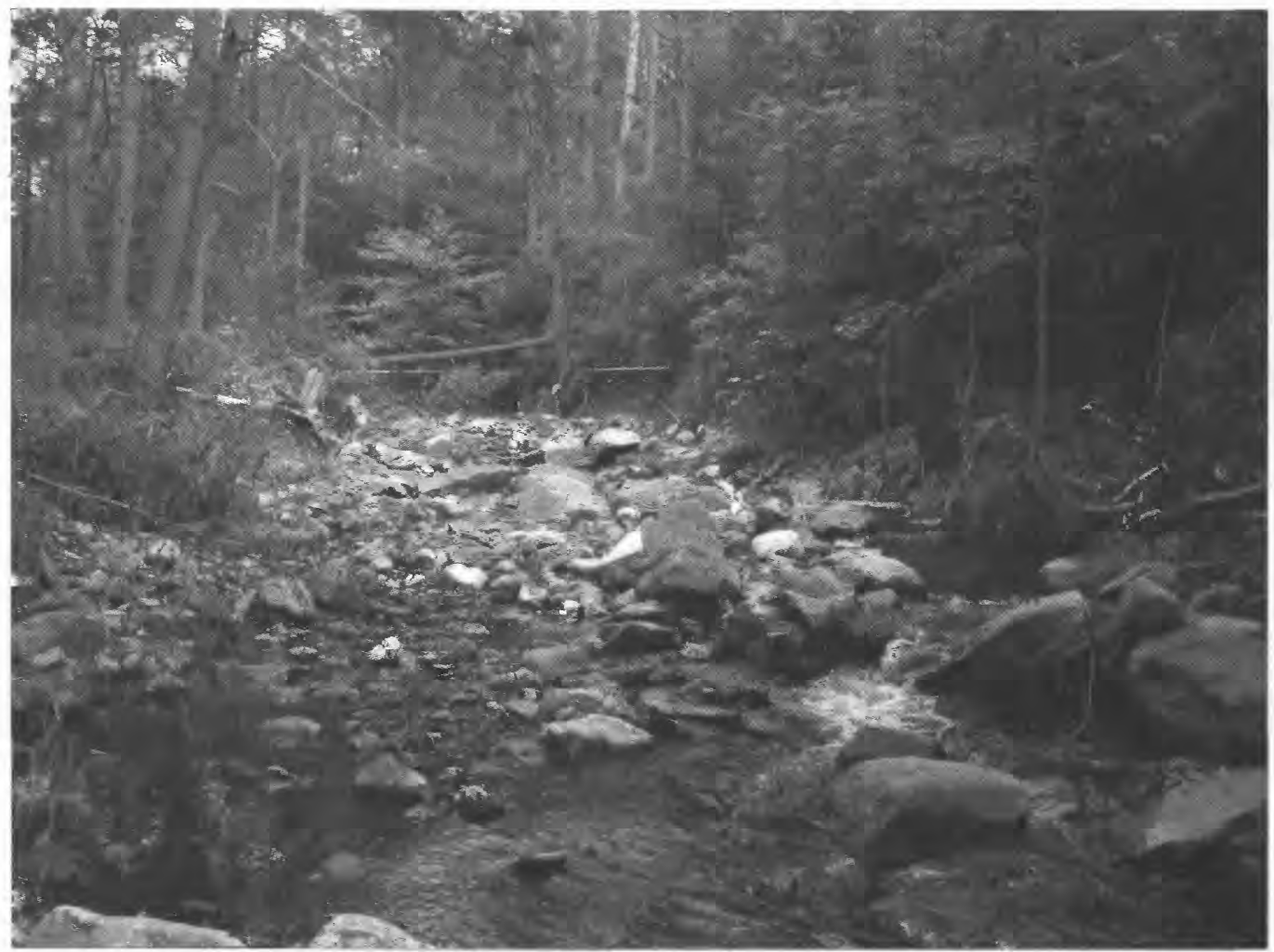

Looking upstream from cross-section 3 near downstream end of slope area reach.

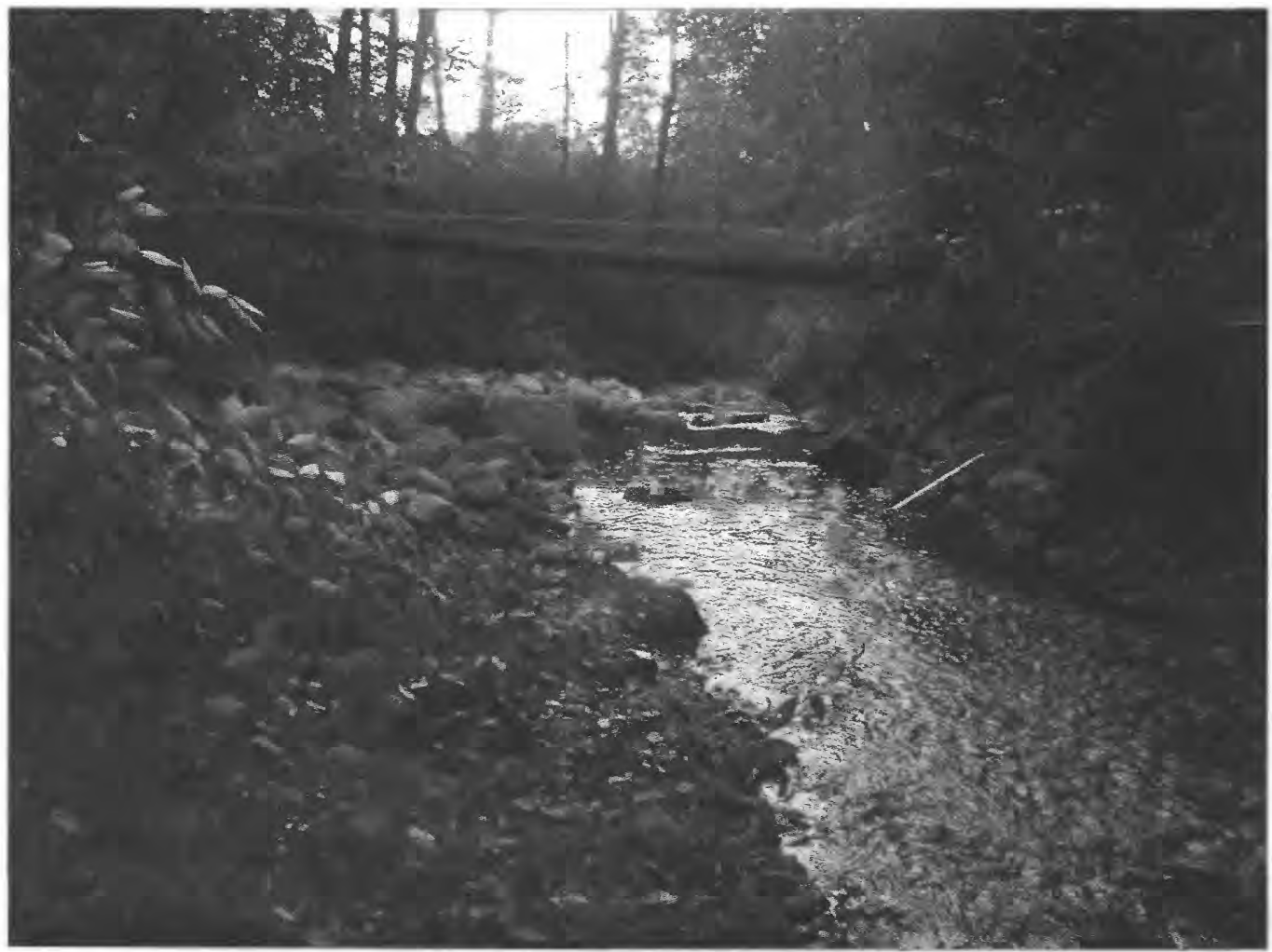

Looking downstream from cross-section 1 near upstream end of slope area reach. 


\section{SITE DESCRIPTION}

Site R1: (USGS streamflow-gaging station 01379630): Russia Brook tributary at Milton, N.J.

Site Location: at a discontinued gaging station, 0.3 mile upstream from Russia Brook, Lat $41^{\circ} 01^{\prime} 04^{\prime \prime}$ long $74^{\circ} 32^{\prime} 30^{\prime \prime}$, NAD 1927. Drainage area: 1.64 square miles.

Jefferson Township, Morris County, New Jersey, Community 340522

Franklin USGS 7.5' Topographic Quadrangle

High-Water Marks: High-water marks (HWM's) flagged for indirect measurement of peak flow. A peak flow of $560 \mathrm{ft}^{3} / \mathrm{s}$ was computed. See indirect-measurement description for peak-flow computation.

Peak flood elevation at gage was 868.4 feet above sea level (5.98 feet gage height).

See field notes for GPS readings at the site. Readings not taken at each HWM.

High-water marks flagged by R.D. Schopp and E.A. Pritchett on September 11, 2000. R.G. Reiser, R.W. Edwards, and G. Holzer surveyed marks to gage datum from staff backing for indirect measurement of flow on September 19-20, 2000. Photos taken of slope area reach and cross sections. Marks were surveyed to sea level on November 8, 2000.

See indirect-measurement notes for description of staff gage, reference mark, and HWM's.

High-water-mark elevations were surveyed from benchmark FEMA 13.

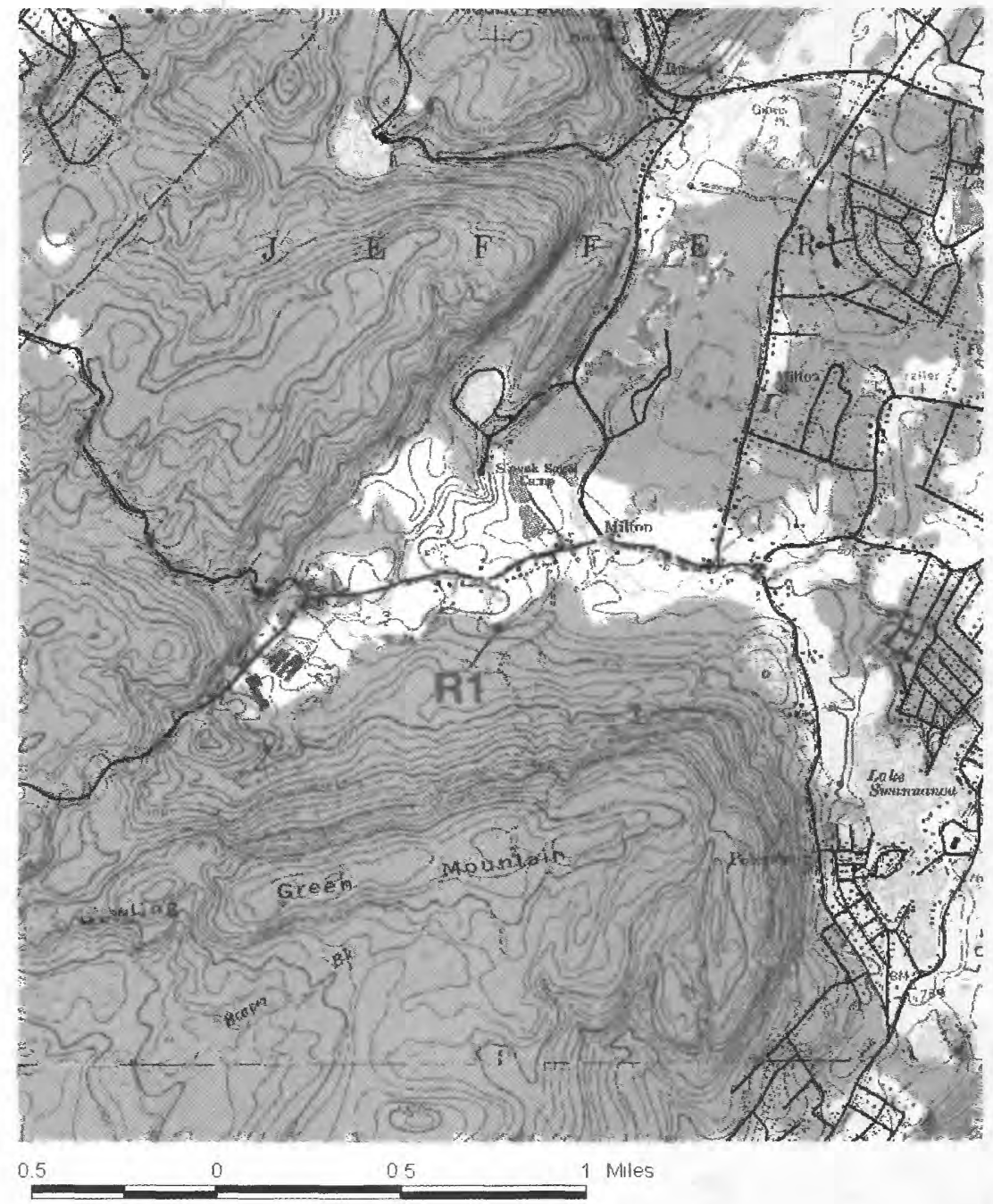

Franklin quad map showing location of site R1 (01379630), Russia Brook tributary at Milton, N.J. 
Site R1 (01379630), Russia Brook tributary at Milton, N.J.

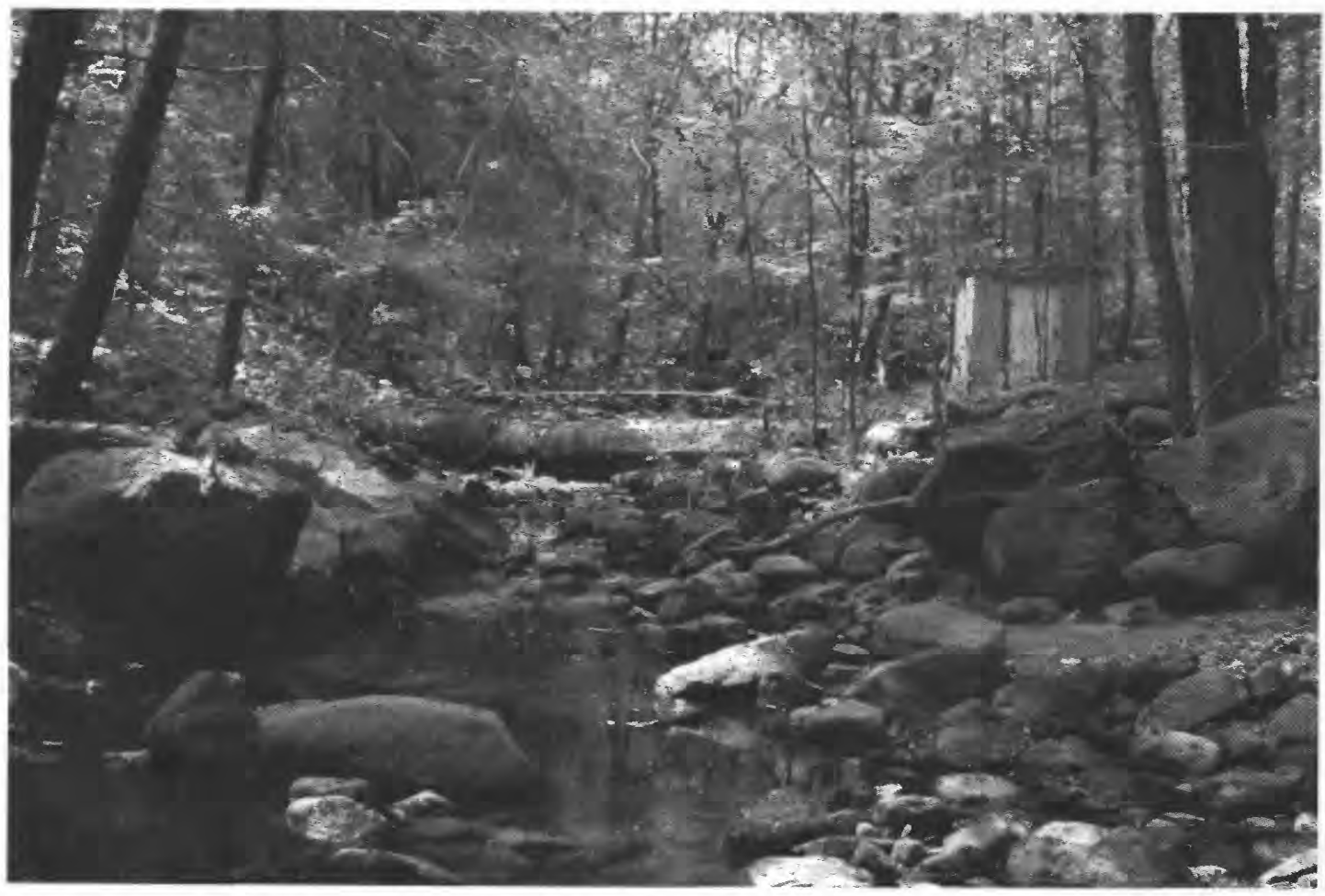

Gage house and weir upstream from slope area reach. Peak elevation at gage is 868.4 feet above sea level.

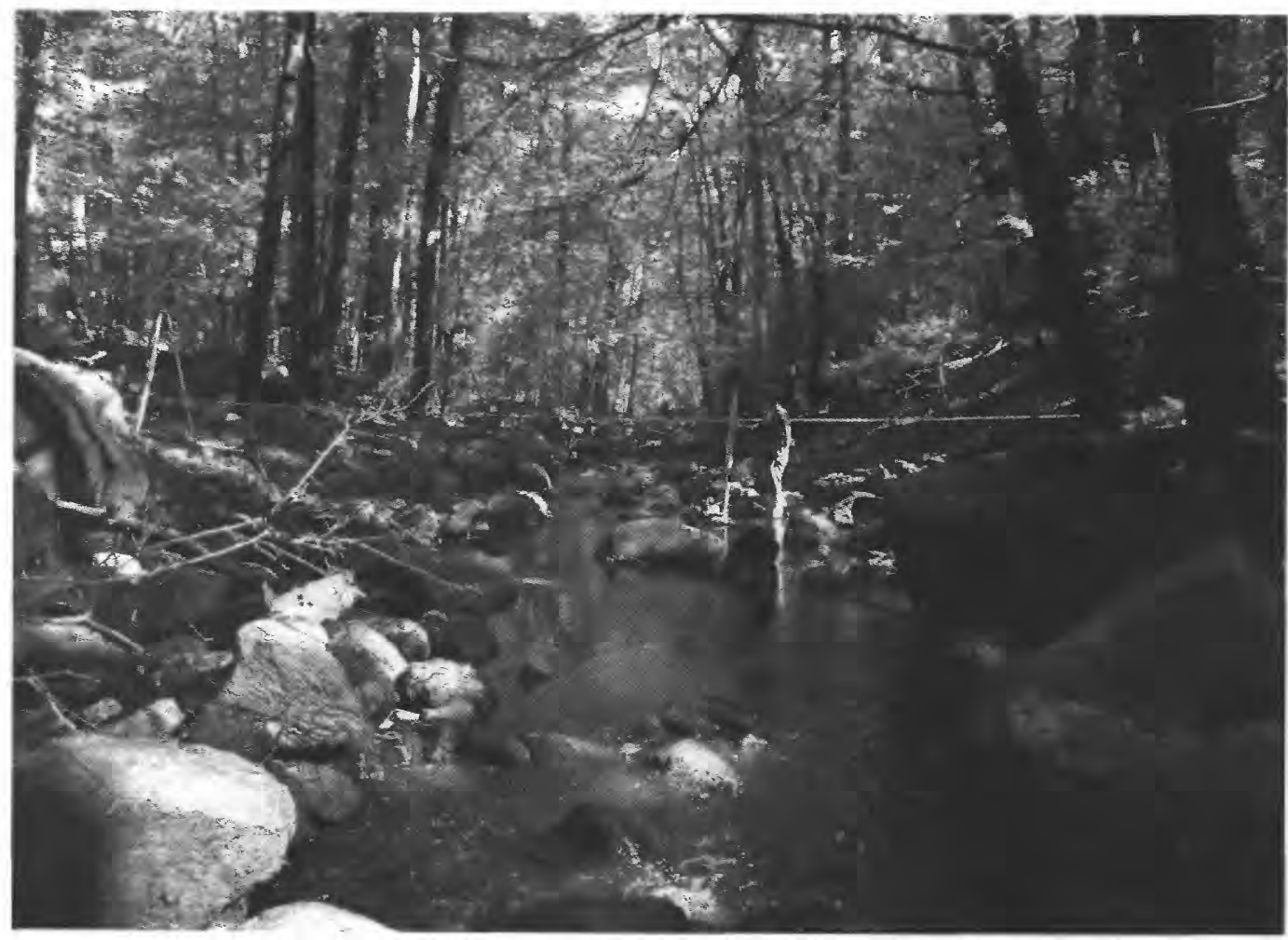

Looking downstream at cross section 1, near the upstream end of the slope area reach. 
Site R1 (01379630), Russia Brook tributary at Milton, N.J.

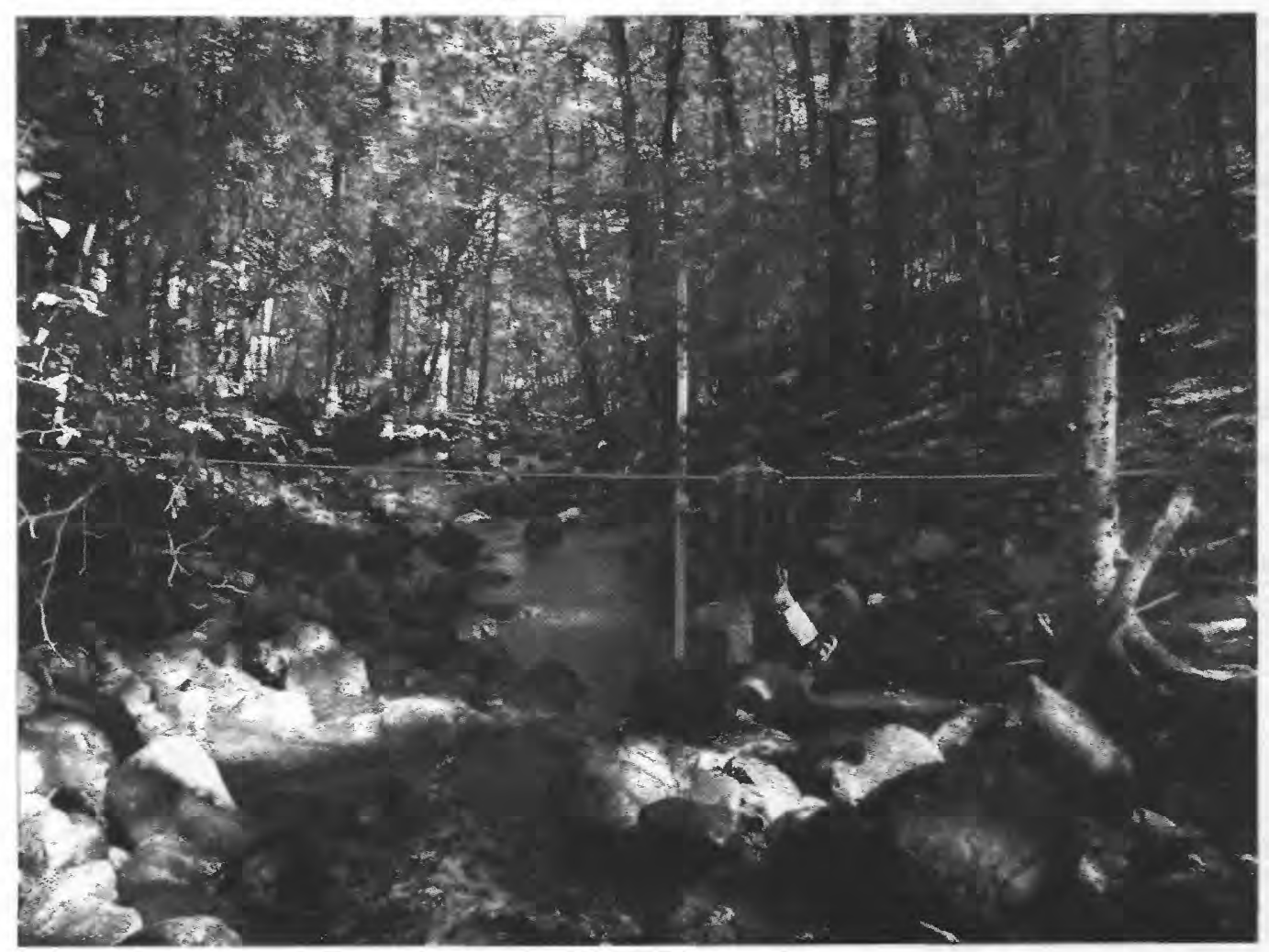

Looking downstream from cross-section 2 , near the middle of the slope area reach. 


\section{SITE DESCRIPTION}

Site W1: Wallkill River at West Shore Drive downstream from Lake Mohawk at Sparta, N.J.

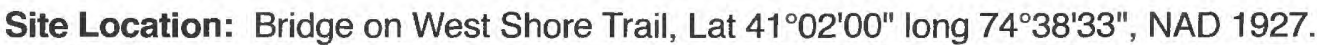

Sparta Township, Sussex County, New Jersey, Community 340535

Newton East USGS 7.5' Topographic Quadrangle

High-Water Marks: Two high-water marks were flagged: 1 fair debris line and 1 unrated debris line.

High-water marks flagged and photos taken by T.J. Reed and R.W. Edwards on September 11, 2000. Surveying was completed on November 1, 2000.

High-water-mark elevations were surveyed from benchmark FEMA reference mark RM8. A description and map locating reference is available.

New State Route 15 and rerouted County Route 517 are shown on the map below but are not shown on the latest 1971 photorevised maps currrently in publication.

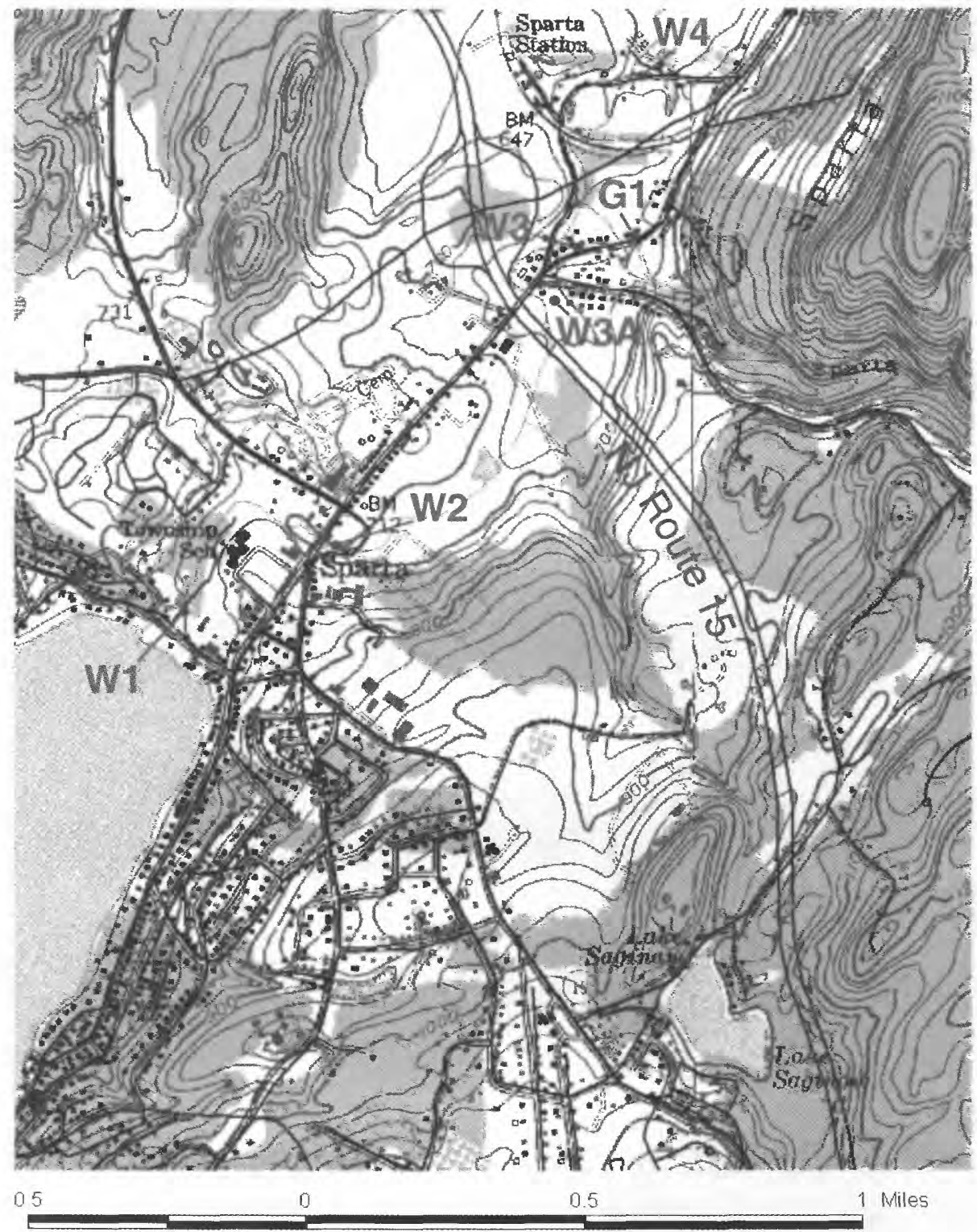

Newton East/Franklin quad map showing location of site W1, Wallkill River at West Shore Drive downstream from Lake Mohawk at Sparta, N.J. 
Site W1 Wallkill River at West Shore Drive downstream of Lake Mohawk at Sparta, N.J.

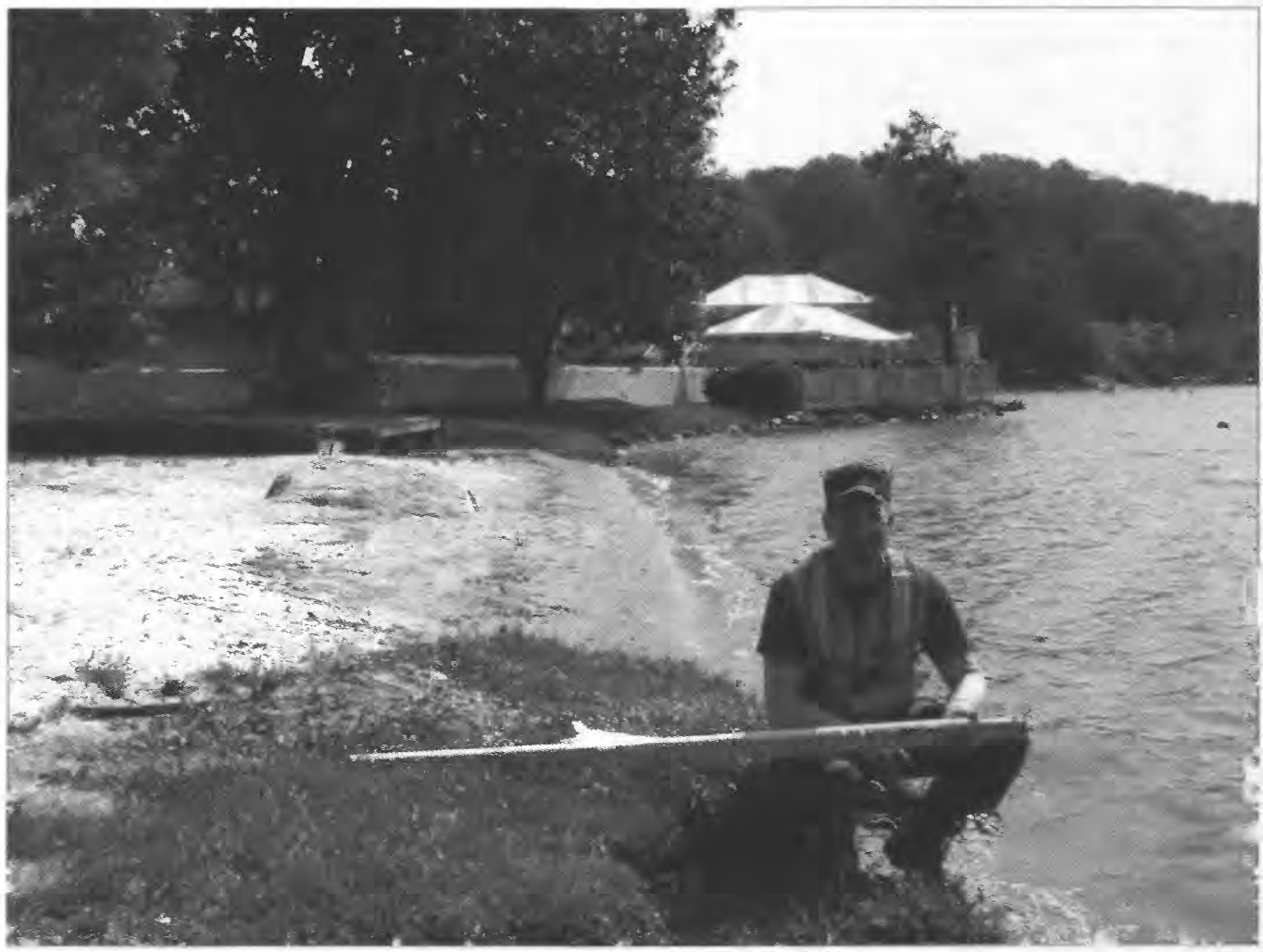

High-water mark W1.1 is a debris line along lake shore, 270 feet upstream from bridge, on right bank, marked by wooden stake. Top of wooden stake is high-water elevation, 730.9 feet above sea level.

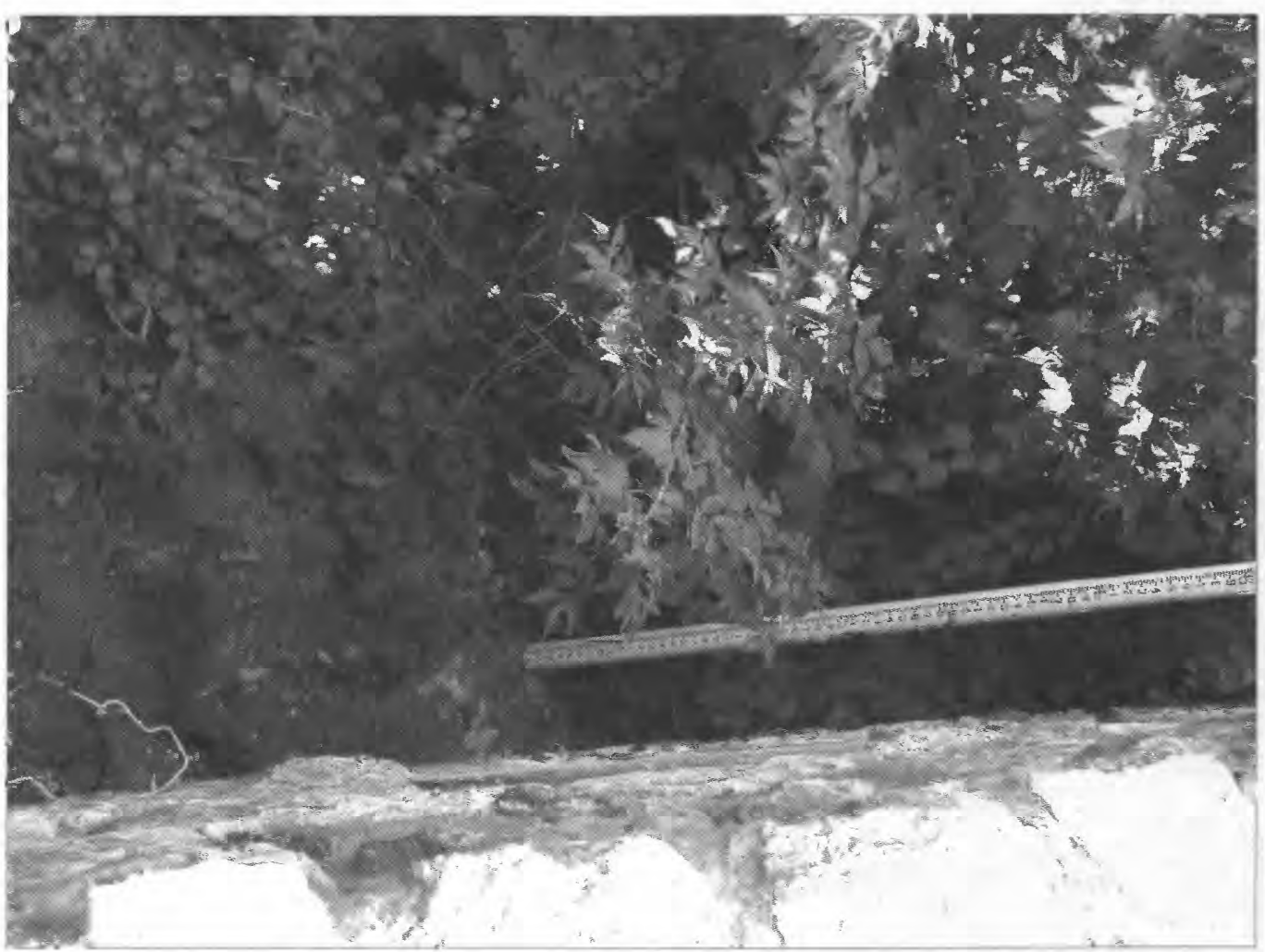

High-water mark W1.2 is a fair debris line on ground level along concrete bank at base of arch, 1 foot downstream from bridge, on right bank, marked by paint, 722.3 feet above sea level. 
Site W1 Wallkill River at West Shore Drive downstream of Lake Mohawk at Sparta, N.J.

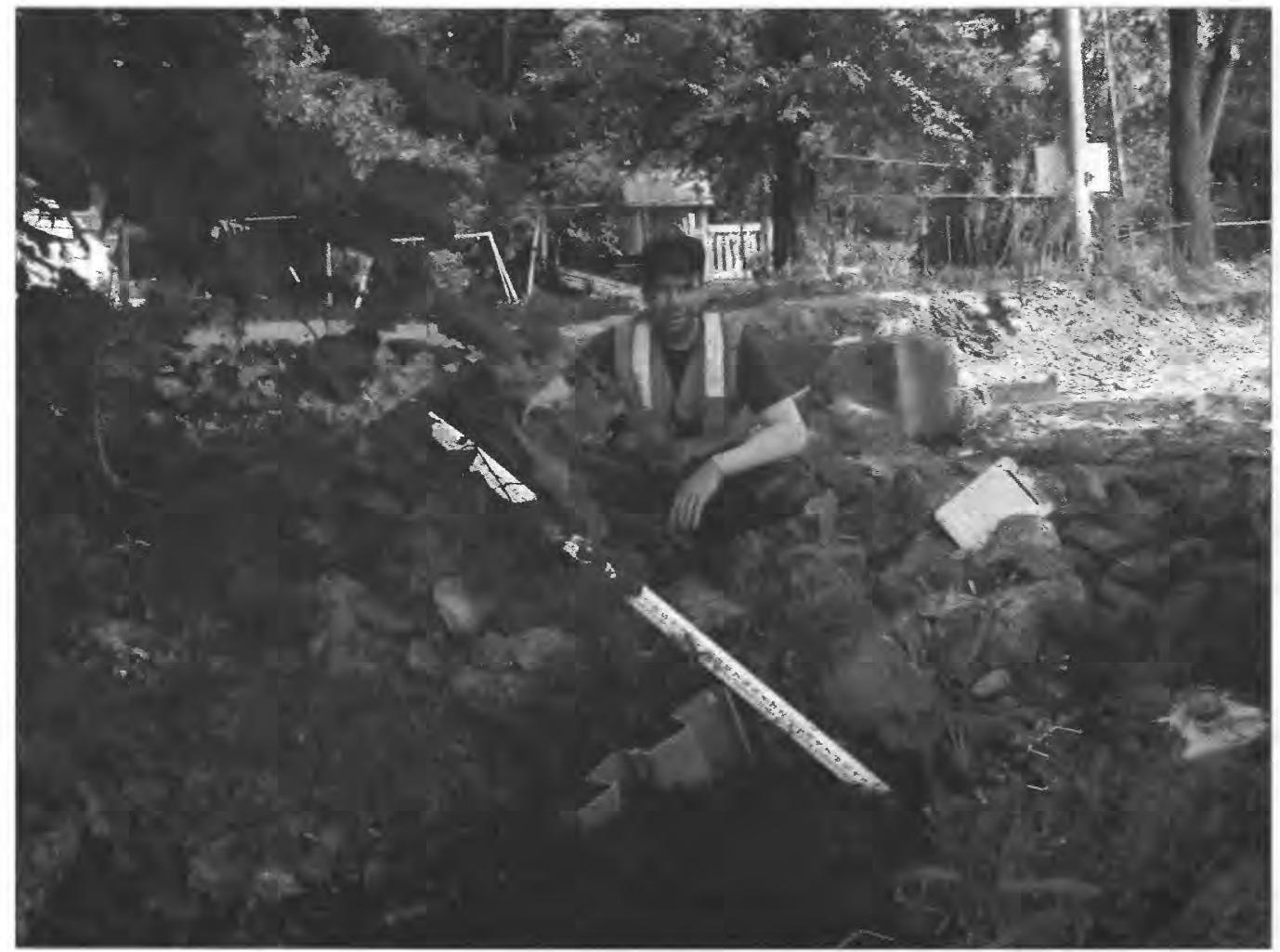

Survey rod is pointing to opening of 2-foot-diameter pipe that diverts flow around the construction site for the new spillway at the outlet of Lake Mohawk. A construction worker who was at the construction site during the flood stated that he was able to move enough earth with a bulldozer in order to contain all of the flow at the outlet through the 2-foot-diameter pipe. 


\section{SITE DESCRIPTION}

Site W2: Wallkill River at Woodport Road at Sparta, N.J.

Site Location: Bridge on Woodport Road, Lat $41^{\circ} 02^{\prime} 06^{\prime \prime}$ long 74³8'14", NAD 1927.

Sparta Township, Sussex County, New Jersey, Community 340535

Newton East USGS 7.5' Topographic Quadrangle

High-Water Marks: Four high-water marks were flagged: 1 fair debris line, 1 poor seed line, and 2 unrated seed lines. An eyewitness account from a local resident verified marks.

Photos of each high-water mark are attached. See field notes for GPS readings at each mark.

High-water marks flagged and photos taken by T.J. Reed and R.W. Edwards on September 11, 2000.

Surveying was completed on November 9, 2000.

High-water-mark elevations were surveyed from benchmark FEMA reference mark RM8. A description and map locating reference is available.

New State Route 15 and rerouted County Route 517 are shown on the map below but are not shown on the latest 1971 photorevised maps currrently in publication.

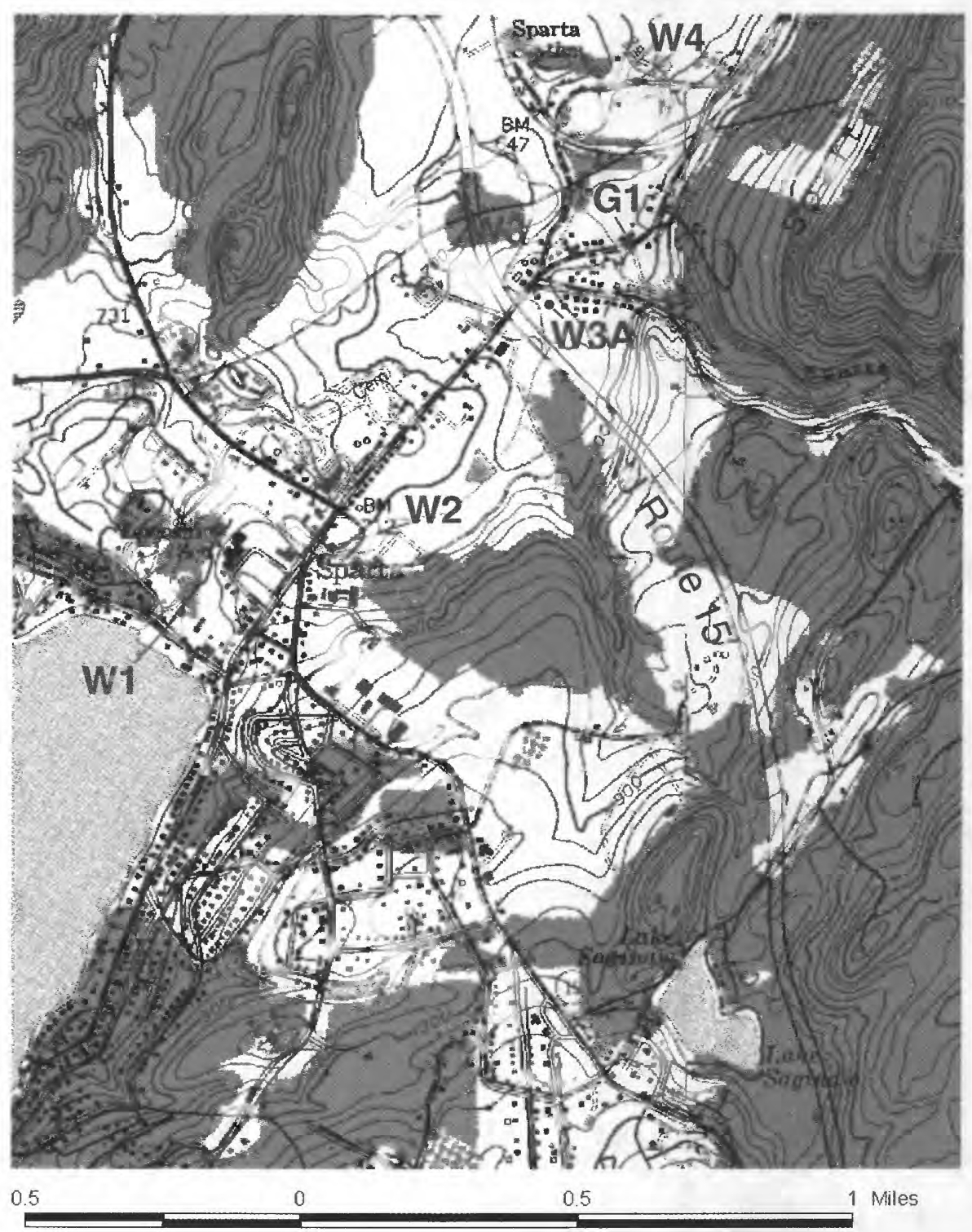

Newton East/Franklin quad map showing location of site W2, Wallkill River at Woodport Road at Sparta, N.J. 
Site W2 Wallkill River at Woodport Road at Sparta, N.J.

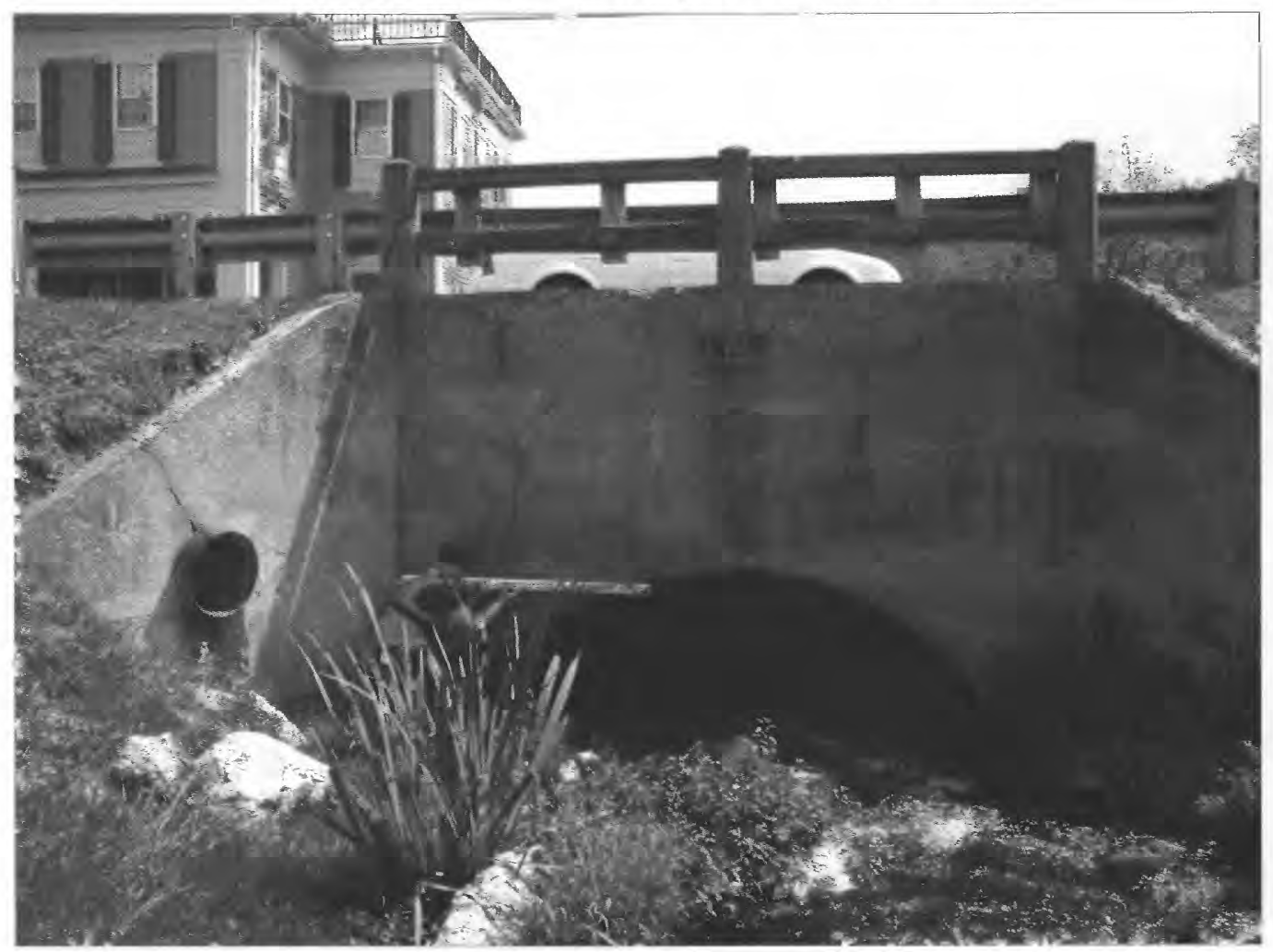

High-water mark W2.1 from an eyewitness account is at upstream center of bridge, 3.7 feet above the streambed. Water level was 4 inches below center of arch, at elevation 694.4 feet above sea level.

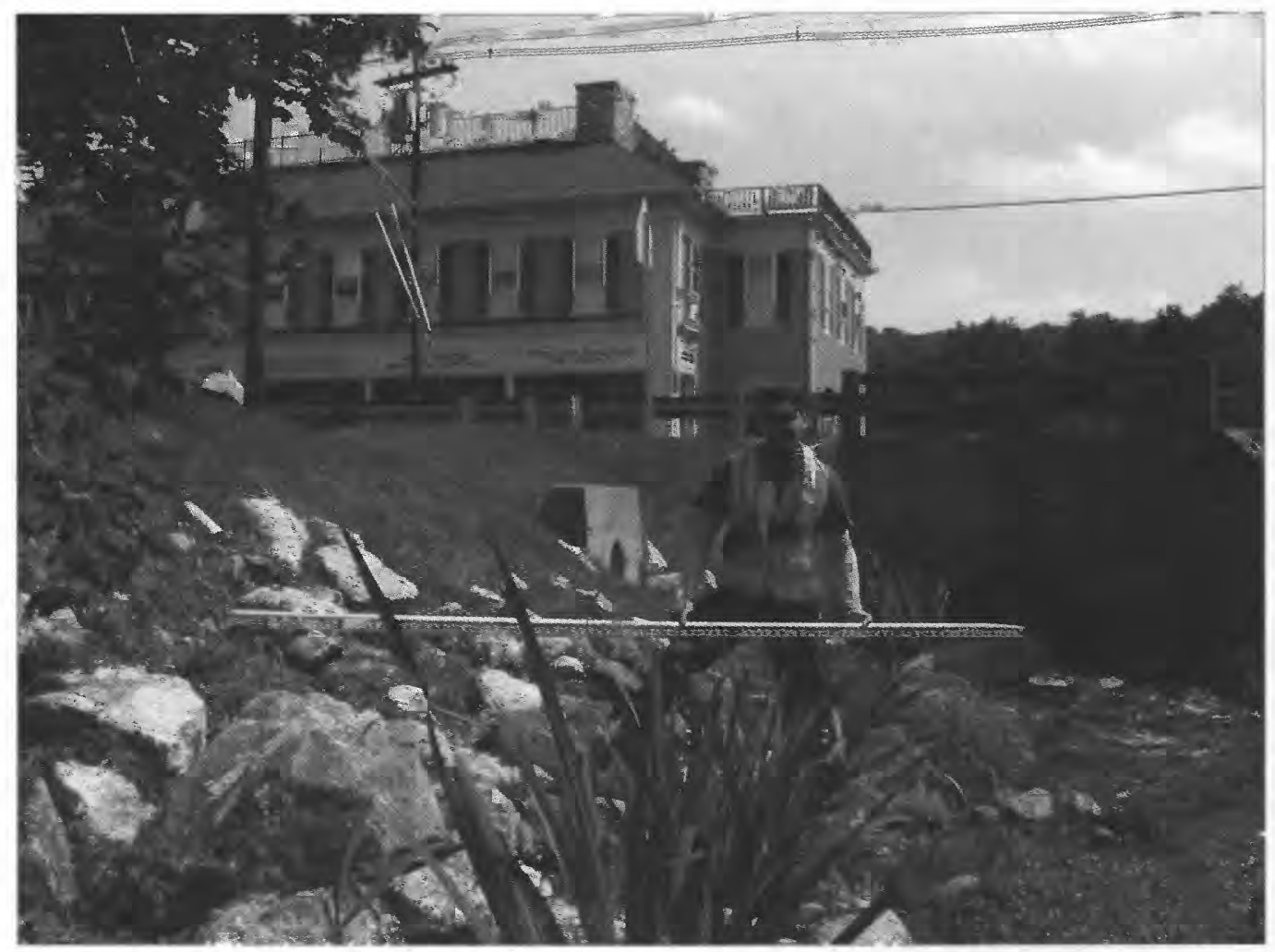

High-water mark W2.2 is a fair debris line on ground on left bank, 40 feet upstream from bridge, at elevation 696.1 feet above sea level. 
Site W2 Wallkill River at Woodport Road at Sparta, N.J.

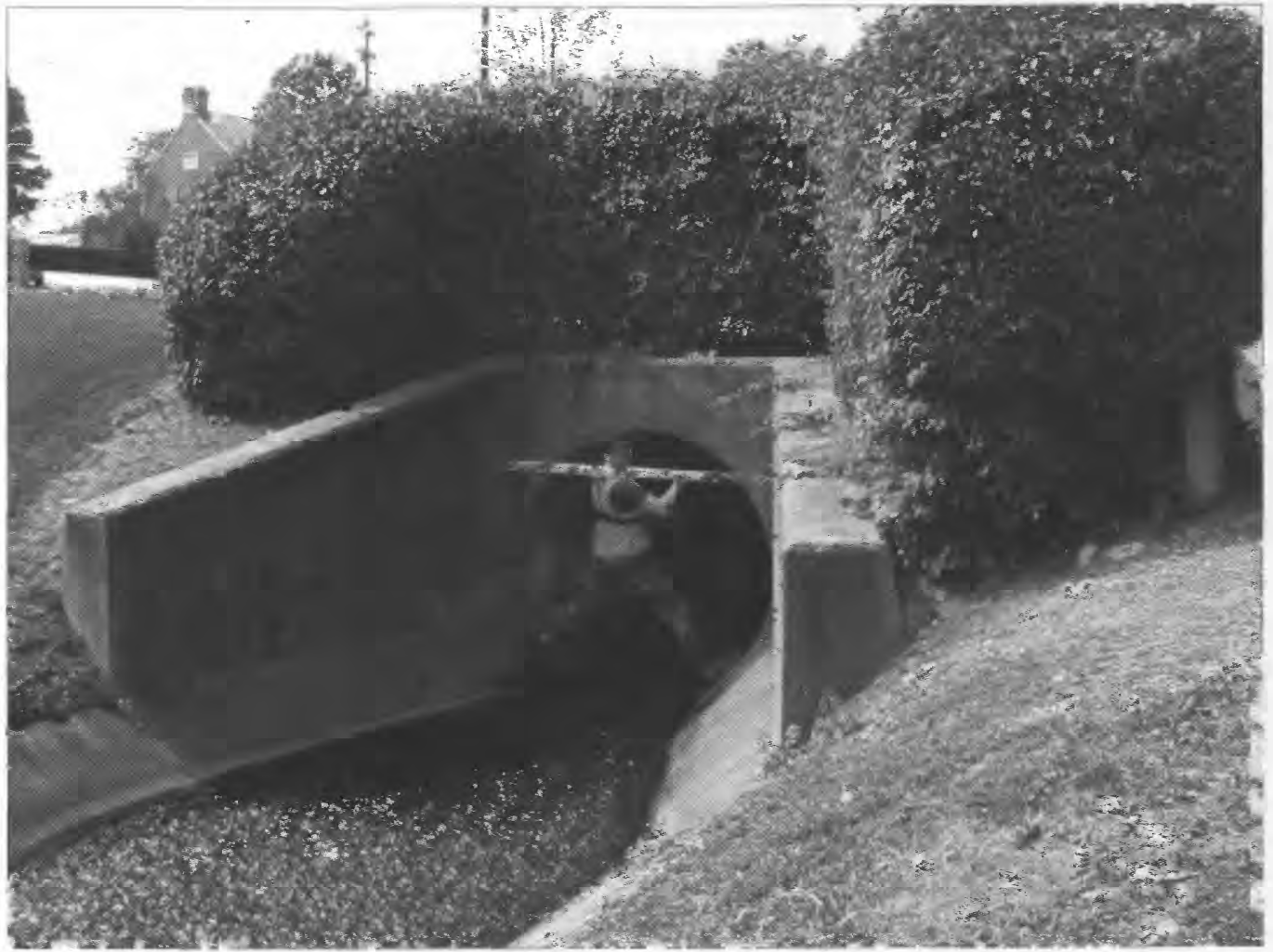

High-water mark W2.3 is a poor seed line at downstream side of culvert at concrete surface at left side of barrel opening, 5.0 feet above ground, at elevation 692.4 feet above sea level.

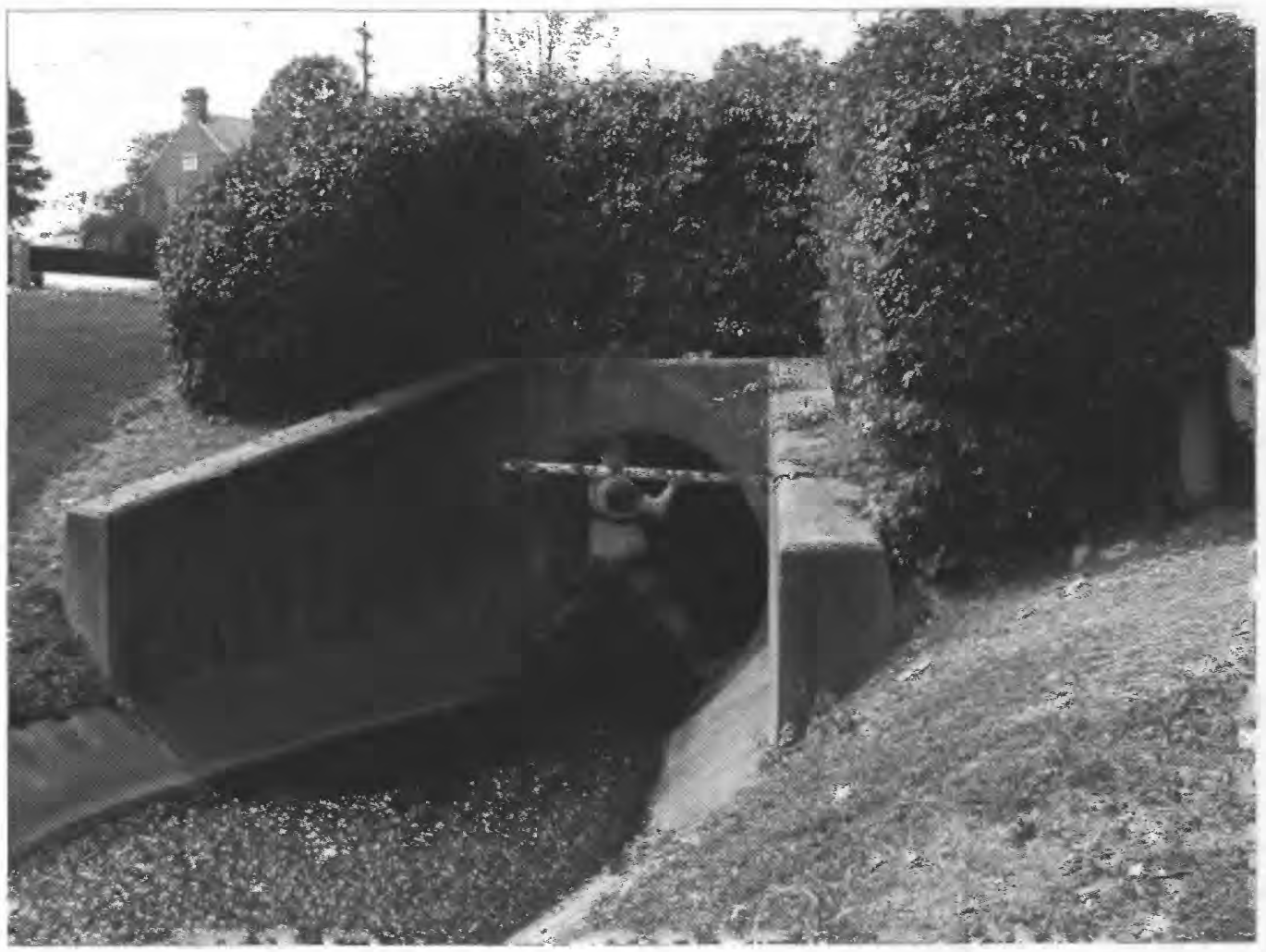

High-water mark W2.4 is a poor seed line at downstream side of culvert on concrete surface at right side of barrel opening, 5.0 feet above ground, at elevation 692.2 feet above sea level. 


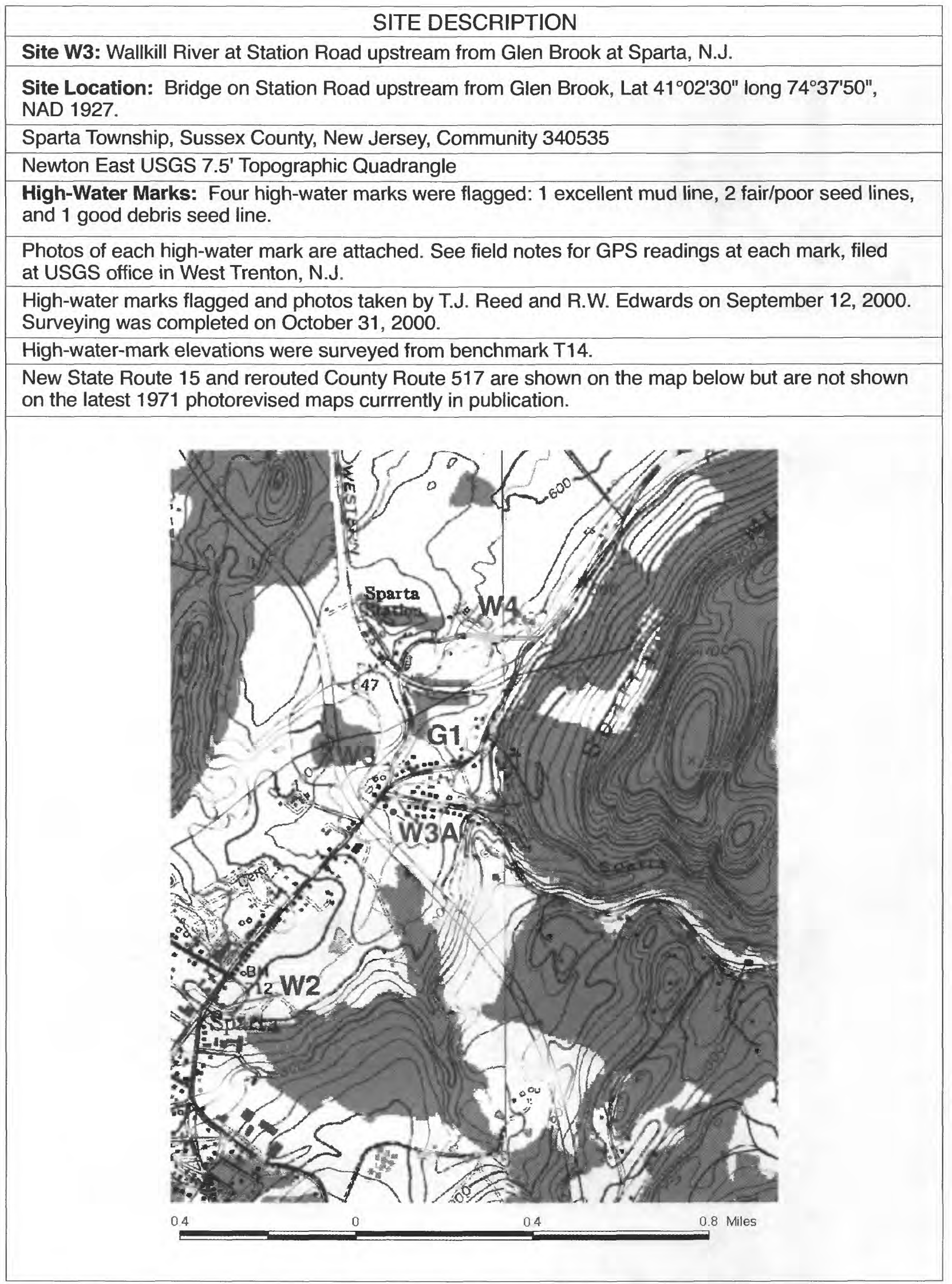

Newton East/Franklin quad map showing location of site W3, Wallkill River at Station Road upstream from Glen Brook at Sparta, N.J. 
Site W3 Wallkill River at Station Road upstream of Glen Brook at Sparta, N.J.

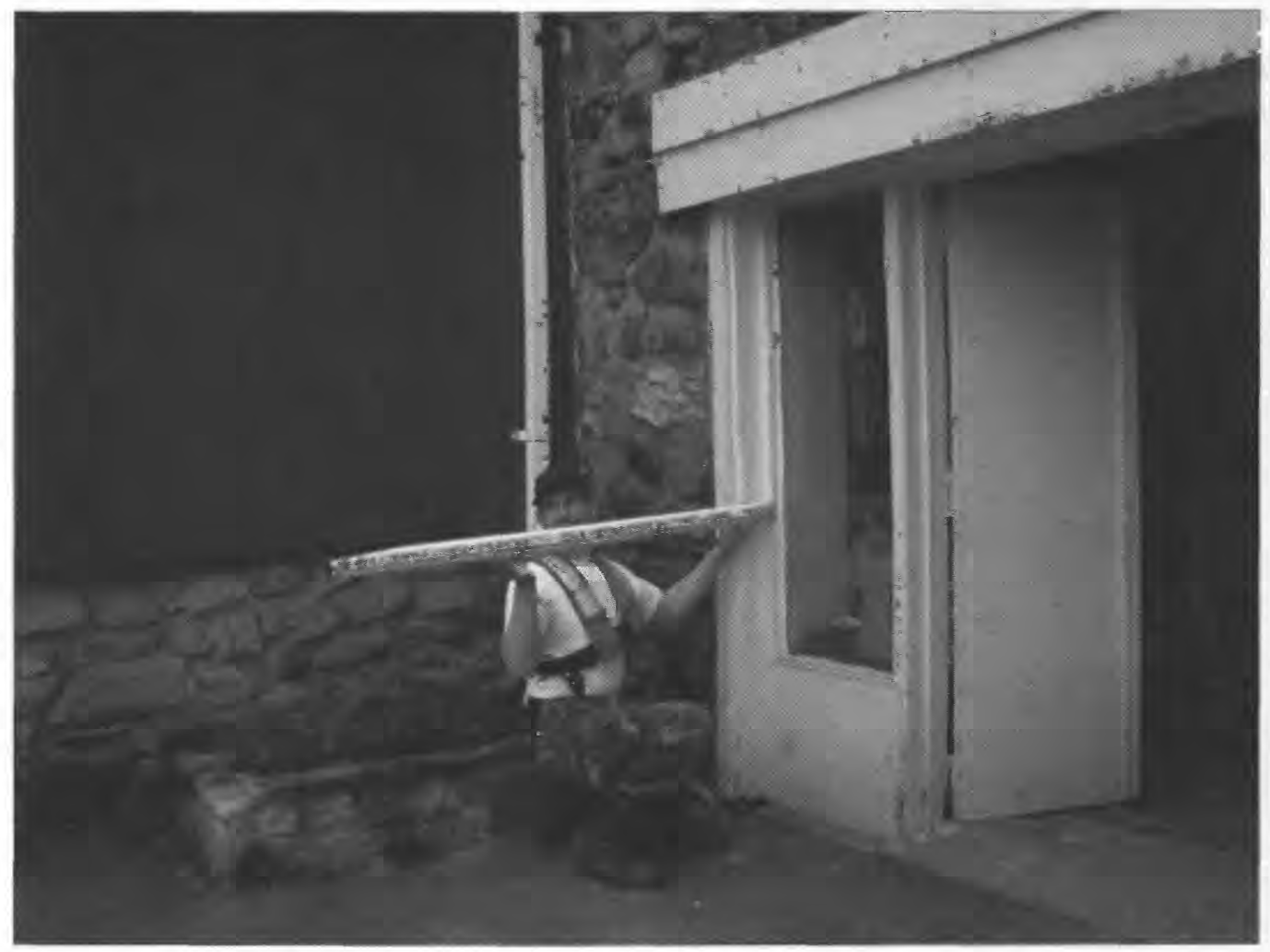

High-water mark W3.1 is an excellent mud line on window and window molding next to garage door, 3.4 feet above pavement, 80 feet to left of upstream side of bridge opening, at elevation 642.4 feet above sea level.

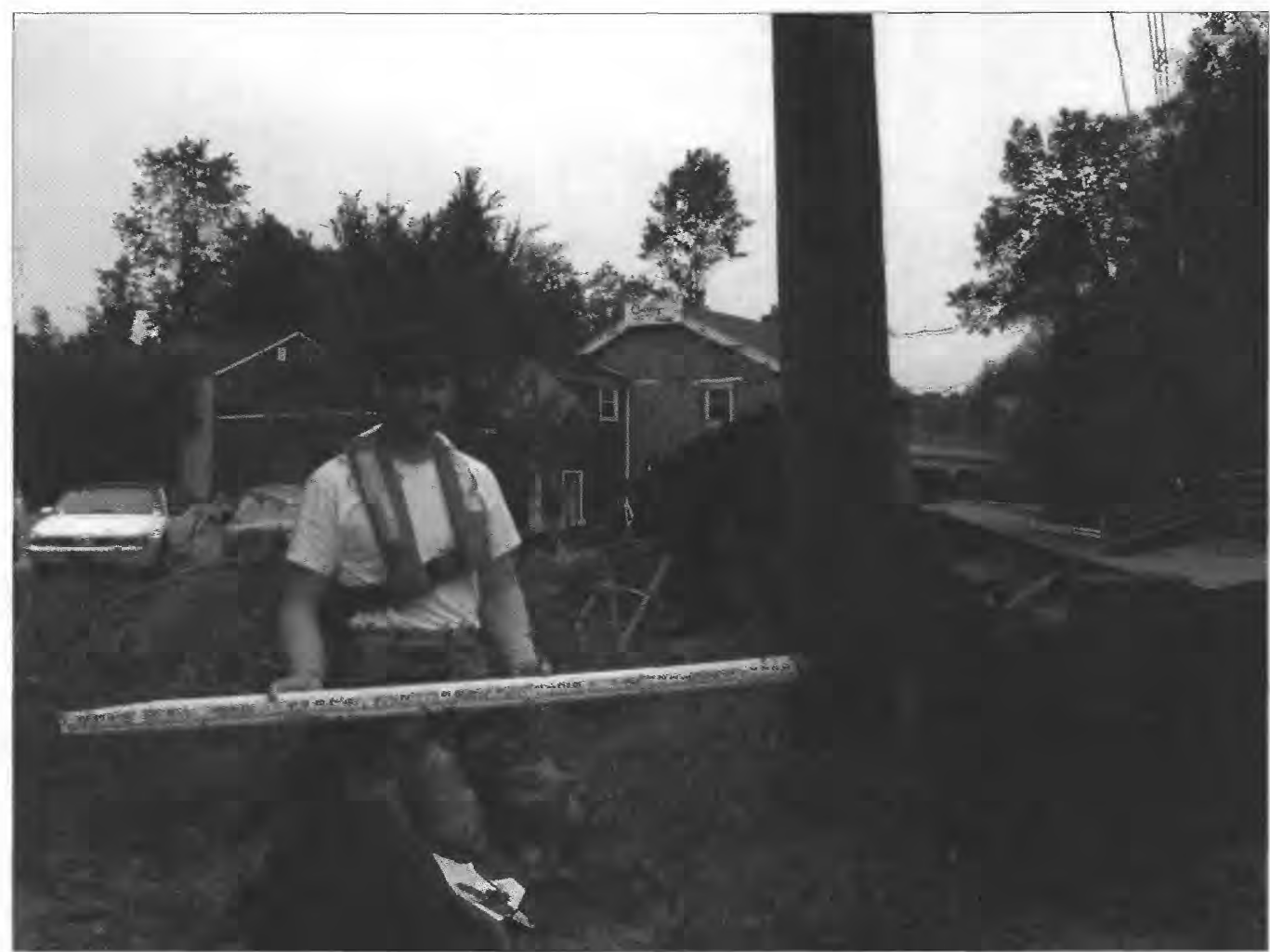

High-water mark W3.2 is a fair seed line on pole, 1.1 feet above ground level, 1.0 foot upstream from bridge on right bank, at elevation 643.6 feet above sea level. 
Site W3 Wallkill River at Station Road upstream of Glen Brook at Sparta, N.J.

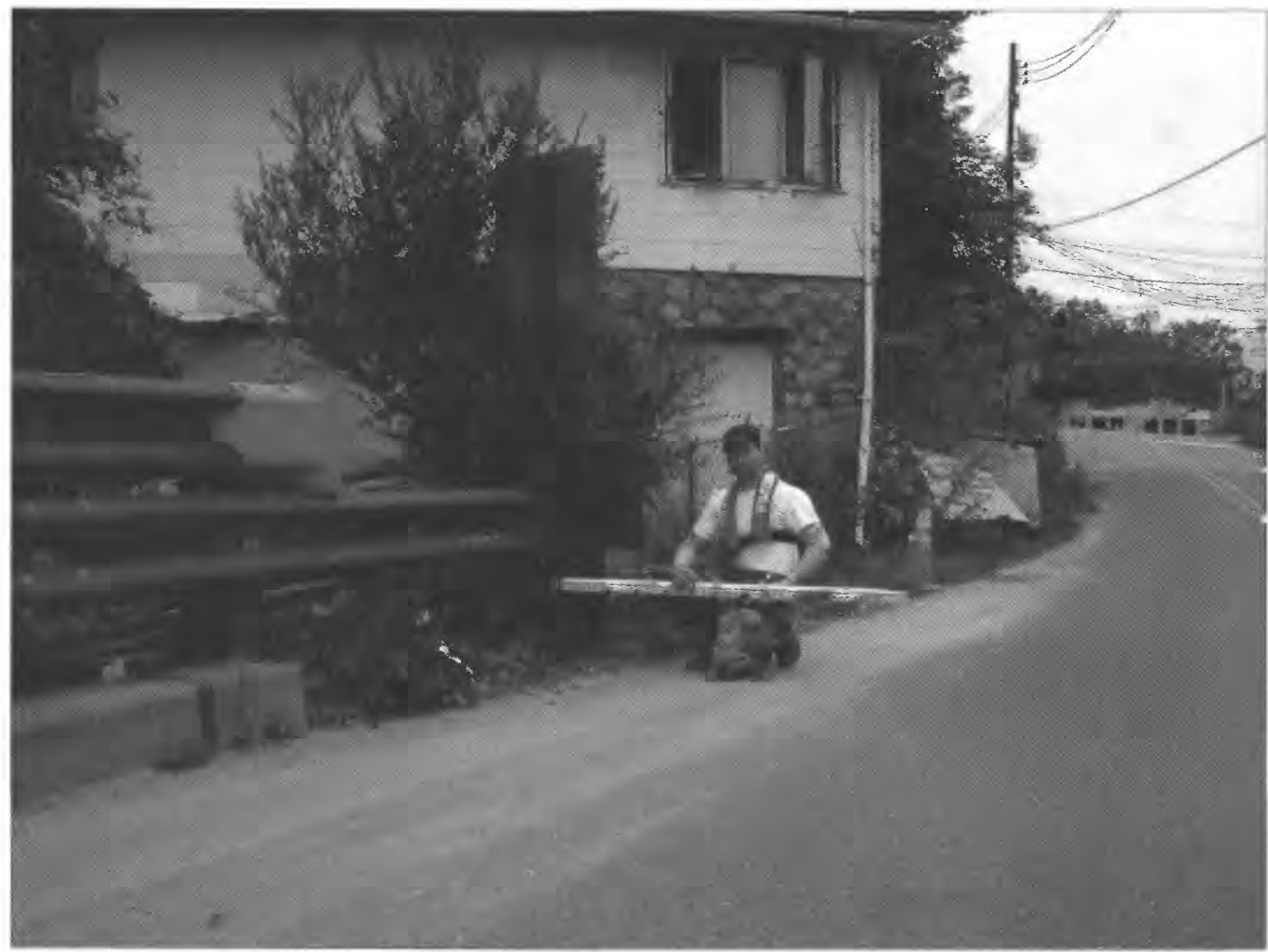

High-water mark W3.3 is a good debris line on sign post, at downstream side of bridge on right bank, and 1.4 feet above ground, at elevation 643.6 feet above sea level.

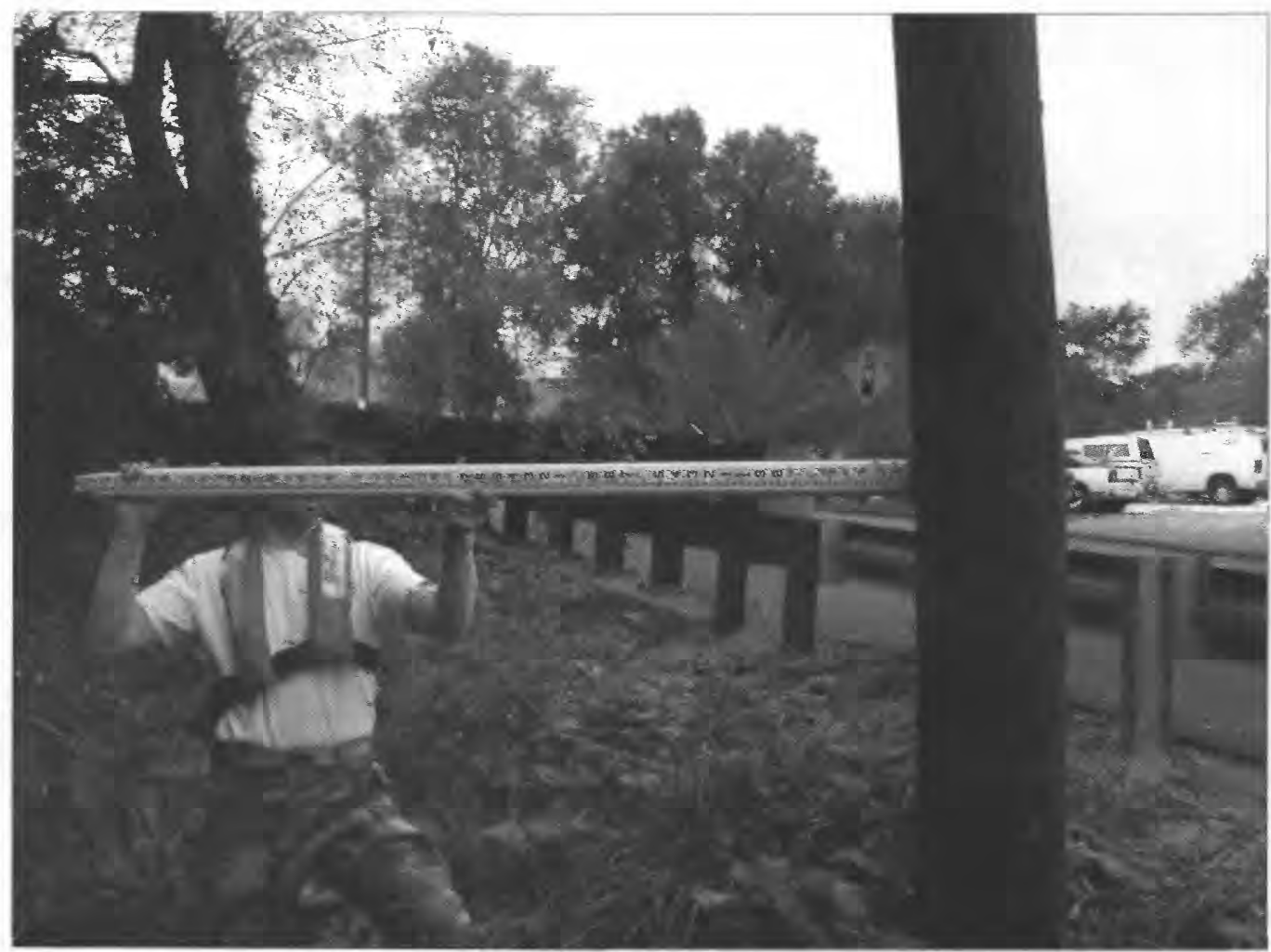

High-water mark W3.4 is a poor seed line on telephone pole \#3 (Utility Company of New Jersey), 20 feet downstream from bridge on left bank, and 4 feet above the sloped river bank, at elevation 642.2 feet above sea level. 
Site W3A: Wallkill River at State Route 620 at Sparta, N.J.

Site Location: Bridge on State Route 620, Lat $41^{\circ} 02^{\prime} 30^{\prime \prime}$ long 743'ㄷ', NAD 1927.

Sparta Township, Sussex County, New Jersey, Community 340535

Newton East USGS 7.5' Topographic Quadrangle

High-Water Marks: Five high-water marks were flagged: 3 good debris lines, 1 good seed line, and 1 poor seed line.

Photos of each high-water mark are attached. See field notes for GPS readings at each mark, filed at USGS office in West Trenton, N.J.

High-water marks flagged and photos taken by T.J. Reed and R.W. Edwards on September 11, 2000. Surveying was completed on October 31, 2000.

High-water-mark elevations were surveyed from benchmark T14.

New State Route 15 and rerouted County Route 517 are shown on the map below but are not shown on the latest 1971 photorevised maps currrently in publication.

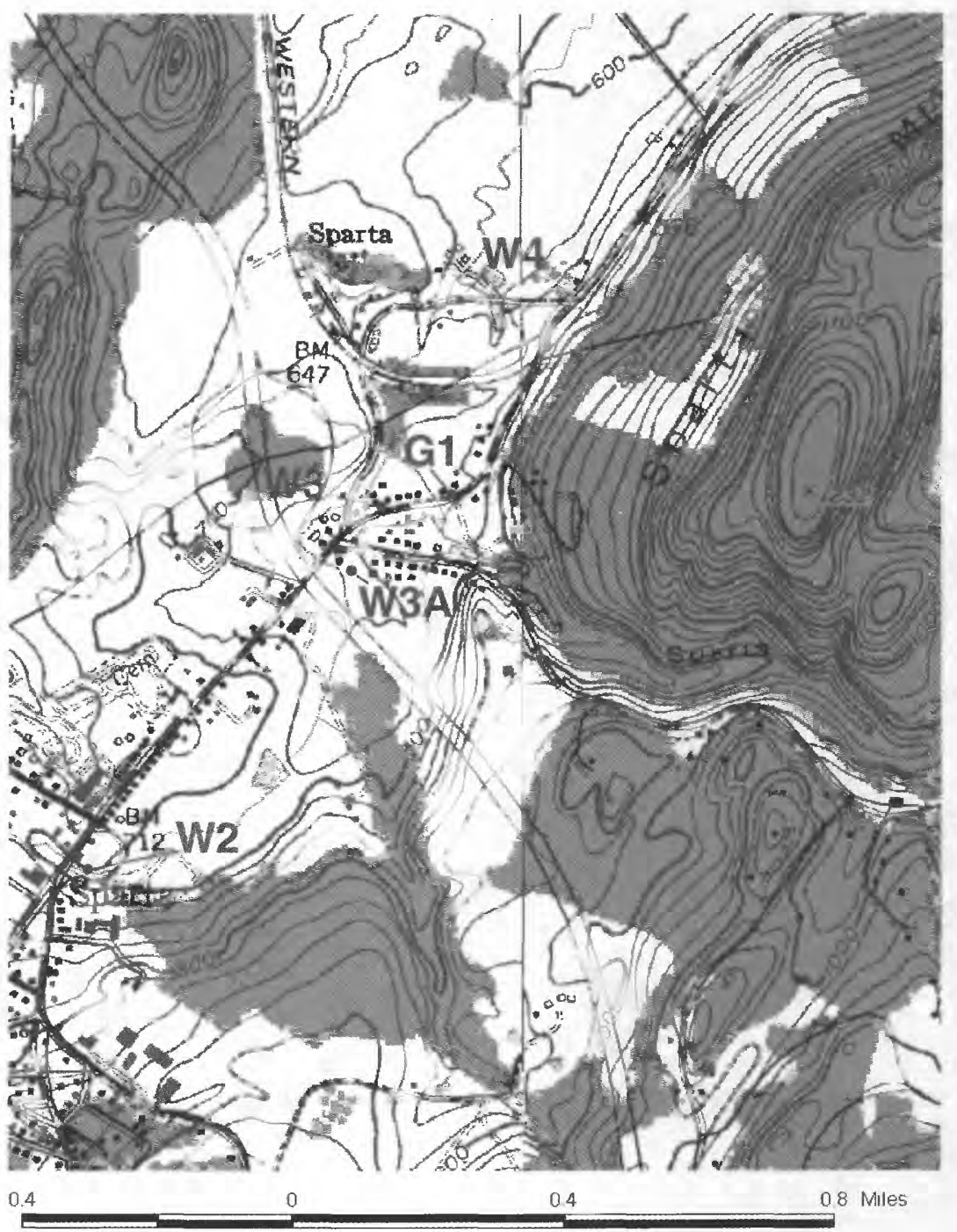

Newton East/Franklin quad map showing location of site W3A, Wallkill River at State Route 620 at Sparta, N.J. 
Site W3a Wallkill River at State Road 620 at Sparta, N.J.

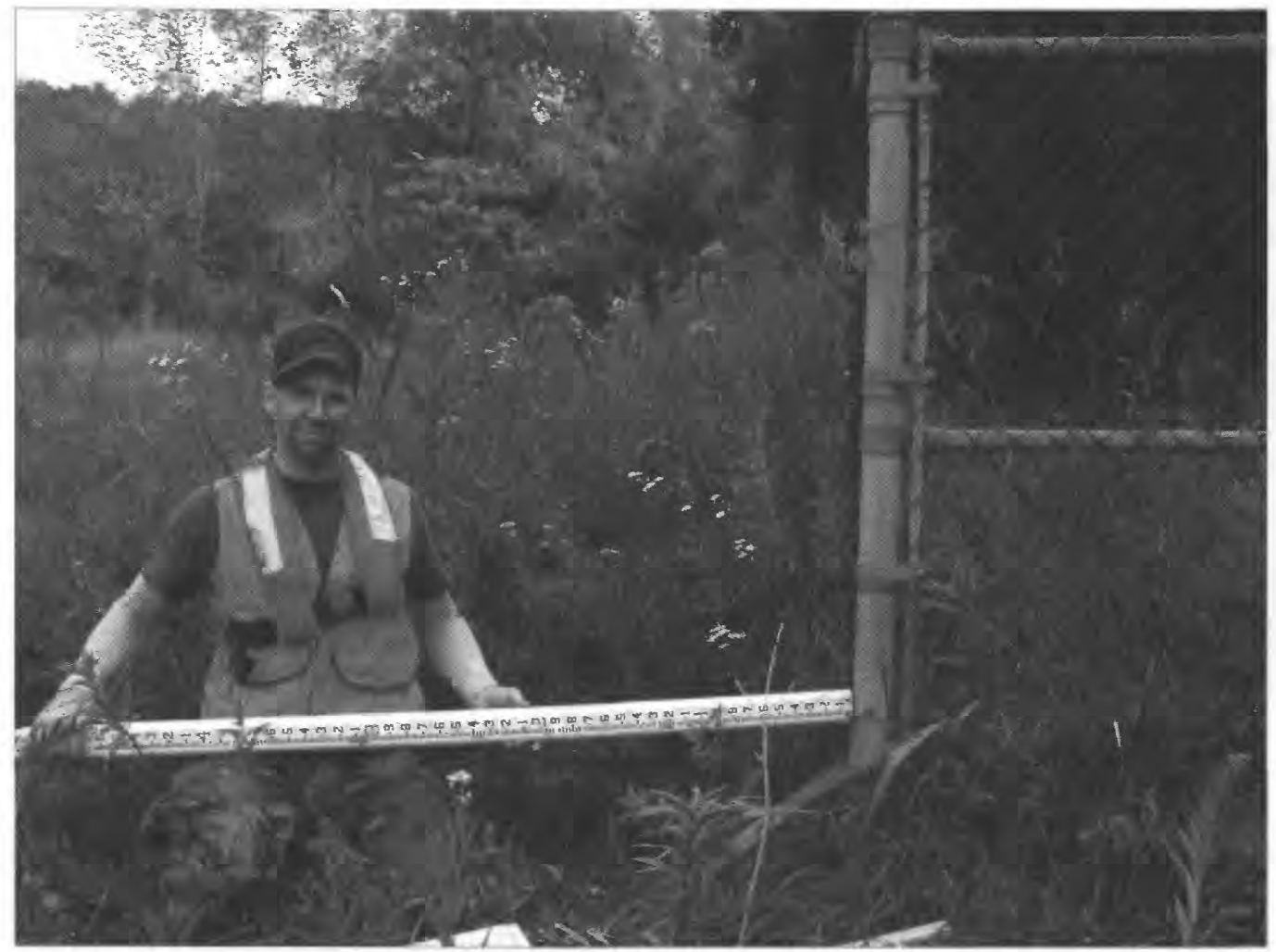

High-water mark W3a. 1 is a good debris line on cyclone fence, 102 feet upstream from bridge on left bank, and 1.2 feet above ground surface, at elevation 651.0 feet above sea level. This elevation probably represents perched streamflow bypassing the bridge.

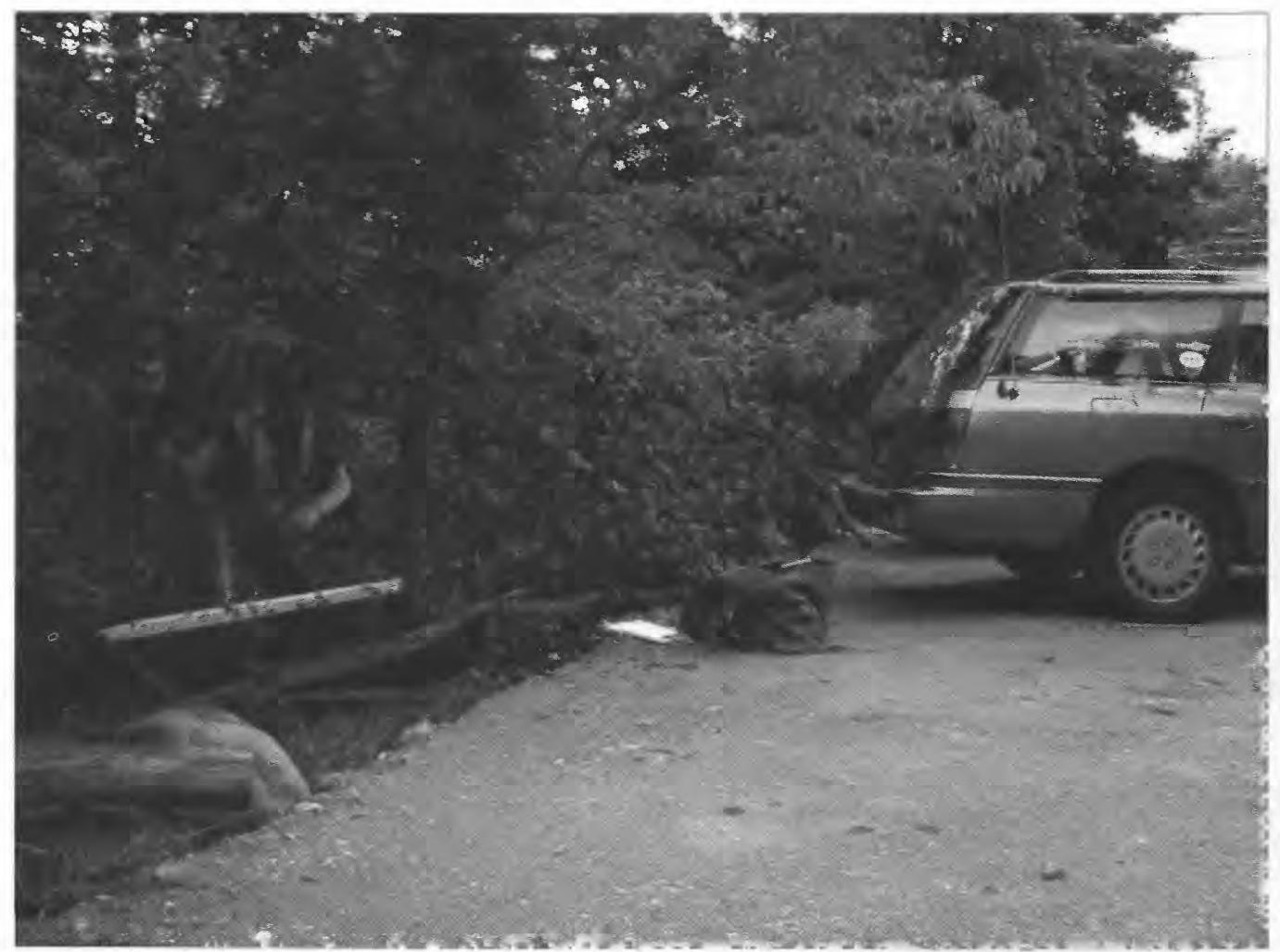

High-water mark W3a.2 is a good debris line on tree, 60 feet upstream from bridge on right bank, and 1.5 feet above ground level, at elevation 649.9 feet above sea level. 
Site W3a Wallkill River at State Road 620 at Sparta, N.J.

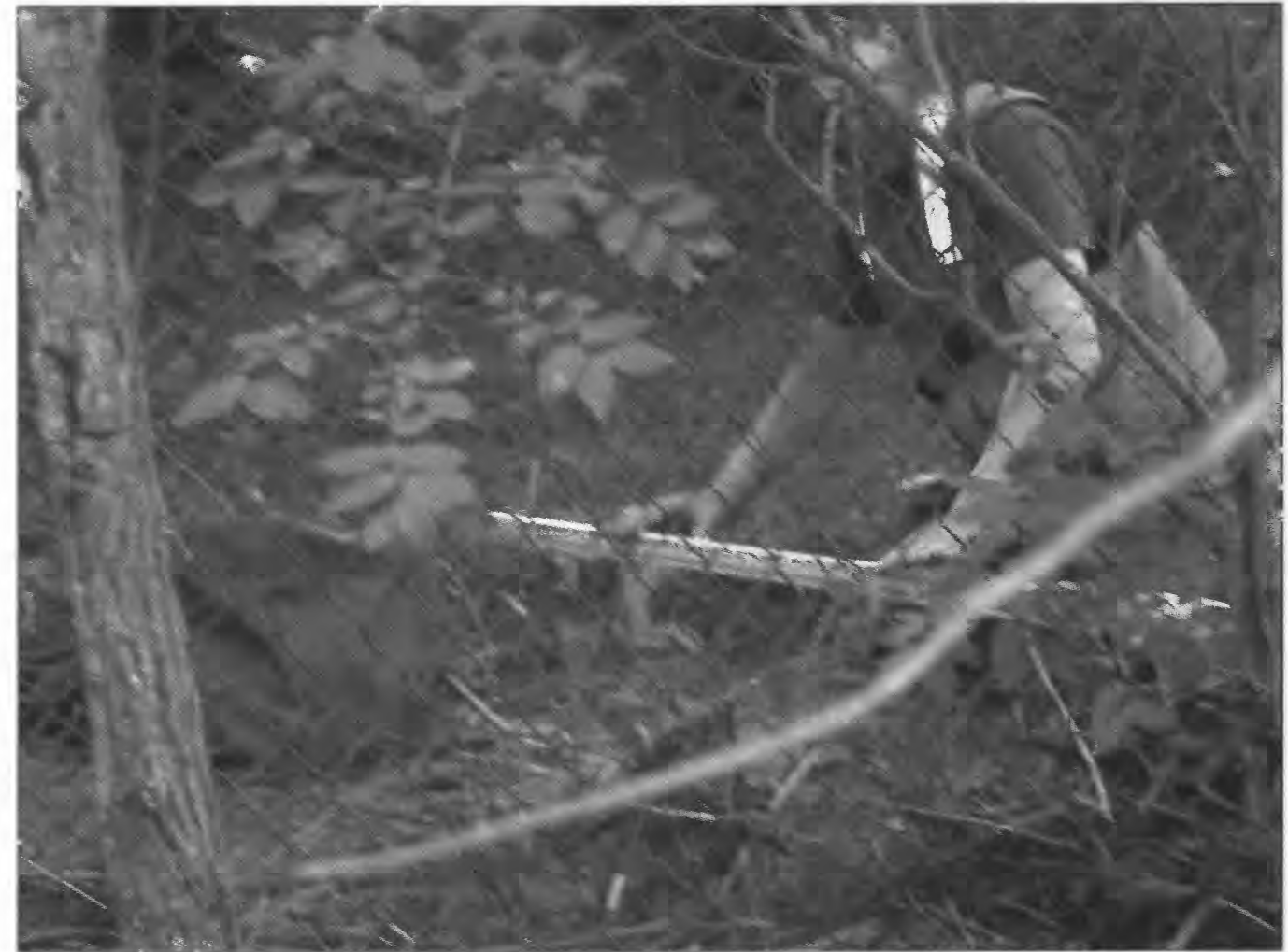

High-water mark W3a.3 is a good debris line on ground, 60 feet downstream from bridge on left bank, at elevation 646.8 feet above sea level.

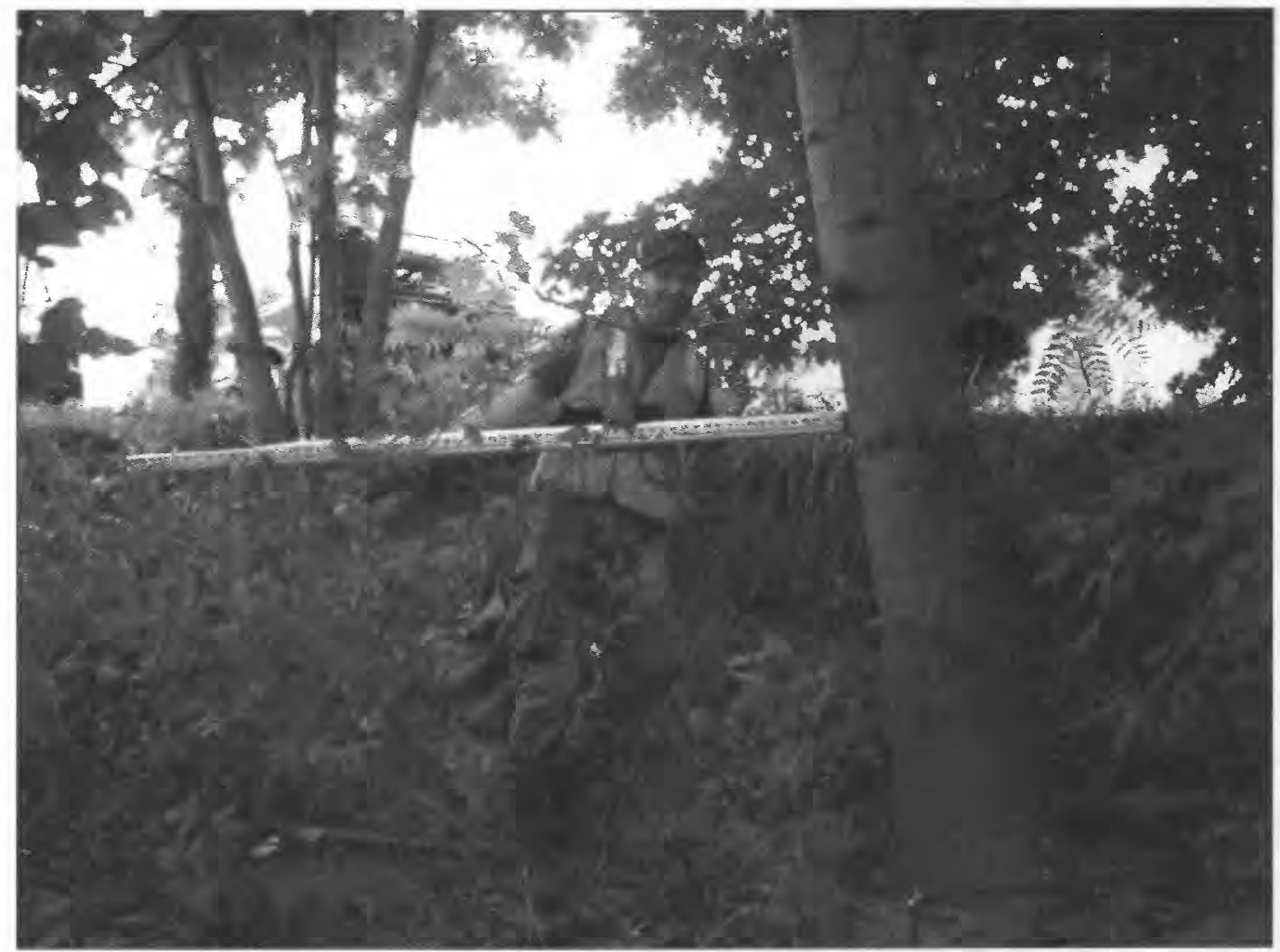

High-water mark W3a.4 is a good seed line on 12-inch-diameter tree, 50 feet downstream from bridge on right bank, and 4.1 feet above ground surface. Mark is close to top of bank, at elevation 647.7 feet above sea level. 
Site W3a Wallkill River at State Road 620 at Sparta, N.J.

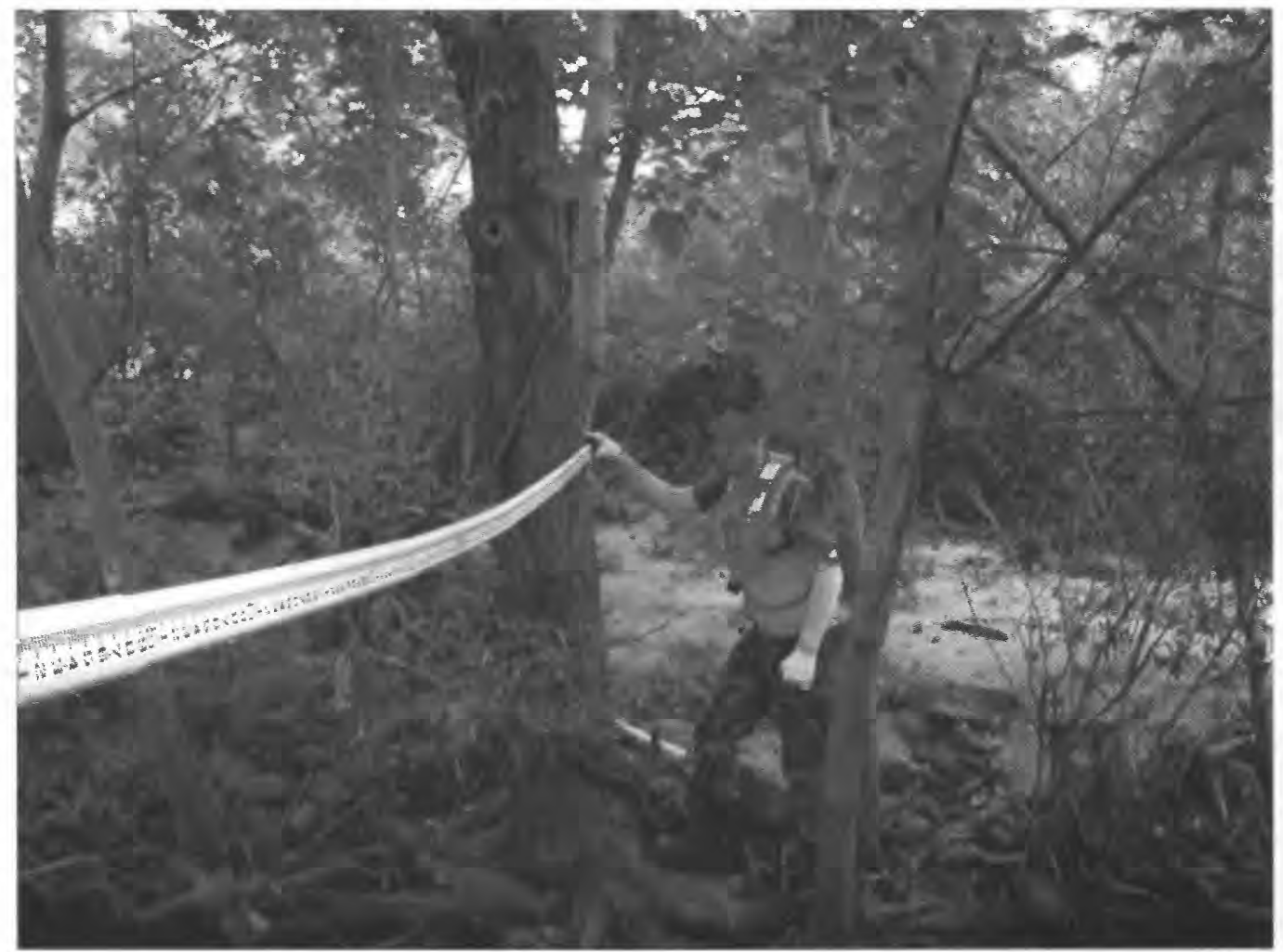

High-water mark W3a.5 is a poor seed line on 14-inch-diameter tree, 30 feet upstream from bridge on left bank. Mark is approximately 4.4 feet above elevation of bank, at elevation 649.7 feet above sea level. 


\section{SITE DESCRIPTION}

Site W4: Wallkill River at Station Road downstream from NYS\&W railroad at Sparta, N.J.

Site Location: Bridge on Station Road, Lat 41 $02^{\prime} 50^{\prime \prime}$ long 74³7'37", NAD 1927.

Sparta Township, Sussex County, New Jersey, Community 340535

Newton East USGS 7.5' Topographic Quadrangle

High-Water Marks: Four high-water marks were flagged: 1 good debris line, 1 fair seed line, and 2 unrated seed lines.

Photos of each high-water mark are attached. See field notes for GPS readings at each mark, filed at USGS office in West Trenton, N.J.

High-water marks flagged and photos taken by T.J. Reed and R.W. Edwards on September 12, 2000. Surveying was completed on October 26, 2000.

High-water-mark elevations were surveyed from benchmark T14.

New State Route 15 and rerouted County Route 517 are shown on the map below but are not shown on the latest 1971 photorevised maps currrently in publication.

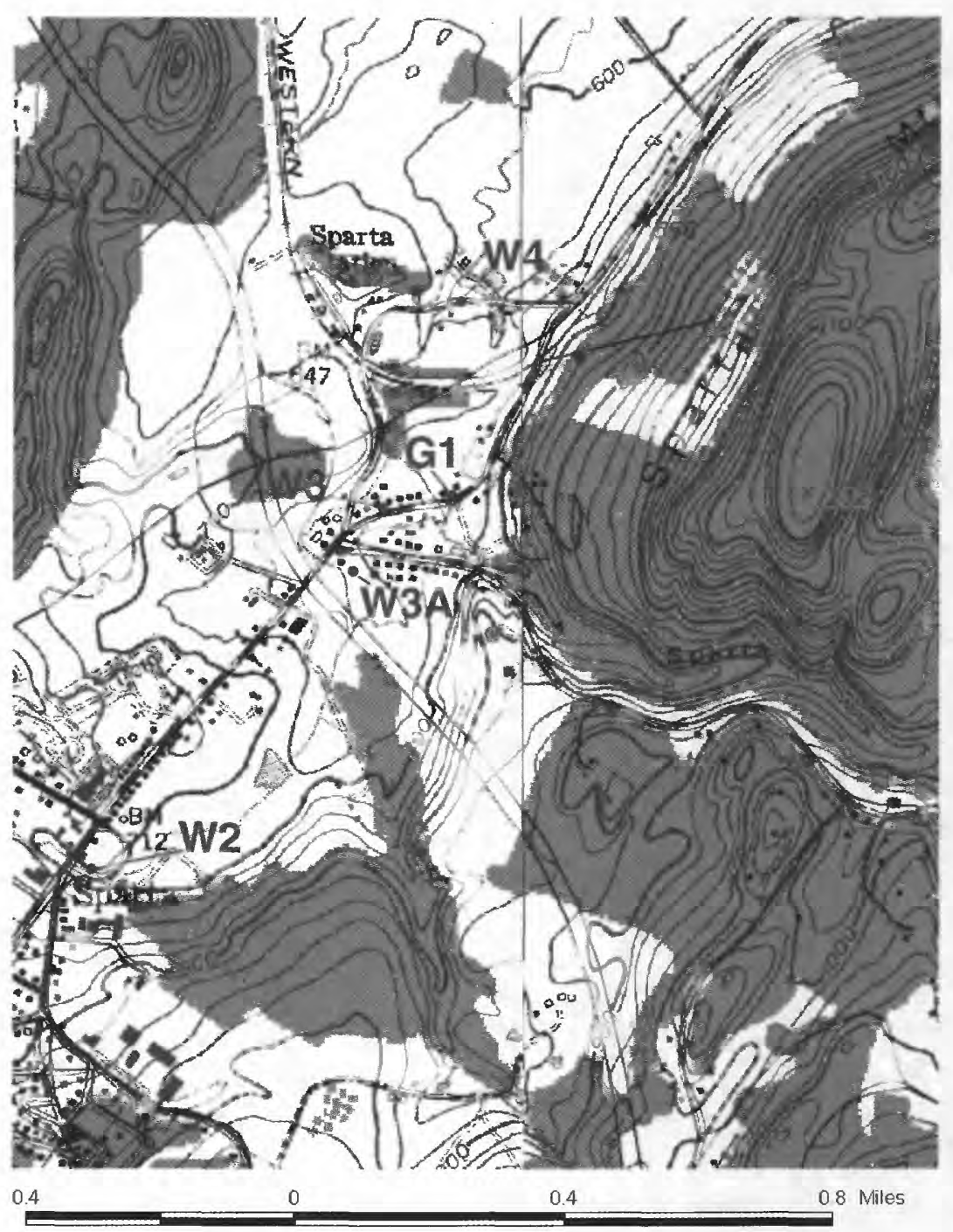

Newton East/Franklin quad map showing location of site W4, Wallkill River at Station Road downstream from NYS\&W railroad at Sparta, N.J. 
Site W4, Wallkill River at Station Road downstream from NYS\&W railroad at Sparta, N.J.

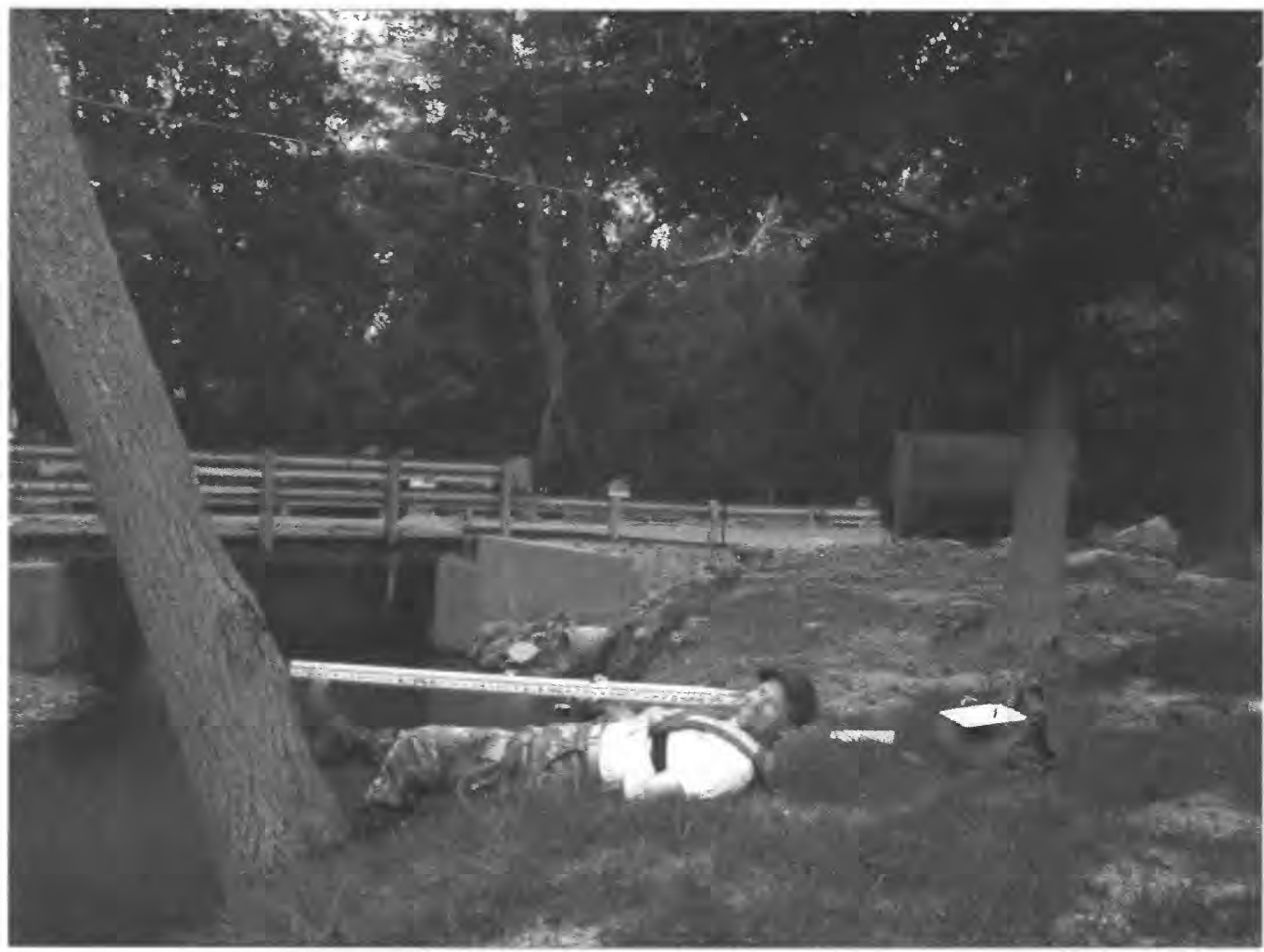

High-water mark W4.1 is a seed line on a 14-inch-diameter tree, 50 feet downstream from bridge, on left bank, and 2.4 feet above ground on bank side of tree, at elevation 613.7 feet above sea level.

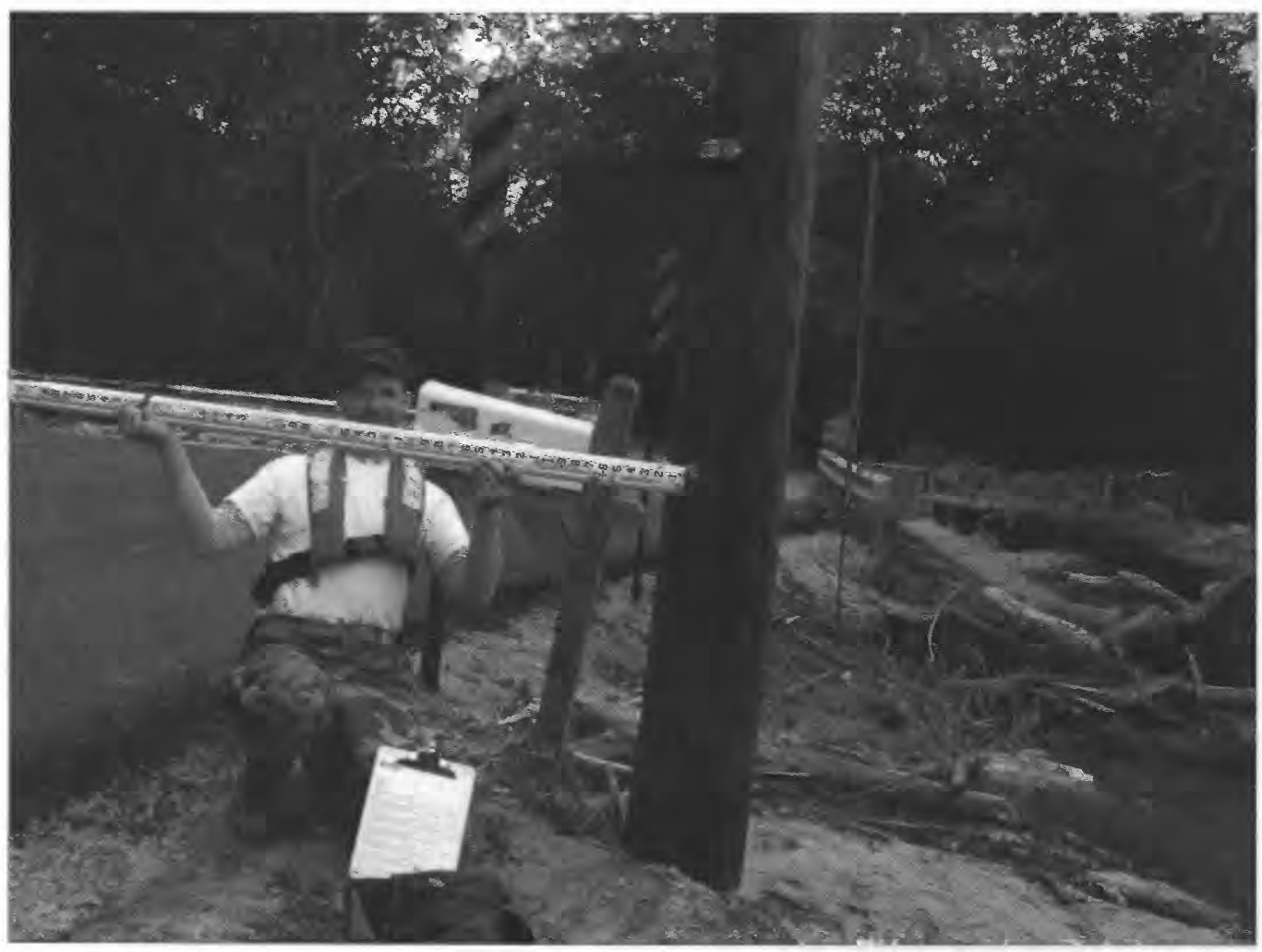

High-water mark W4.2 is a fair seed line on telephone pole J92 7 J202 NJ1206ST, at downstream side of bridge, on right bank, and 3.2 feet above ground, at elevation 615.4 feet above sea level. 
Site W4, Wallkill River at Station Road downstream from NYS\&W railroad at Sparta, N.J.

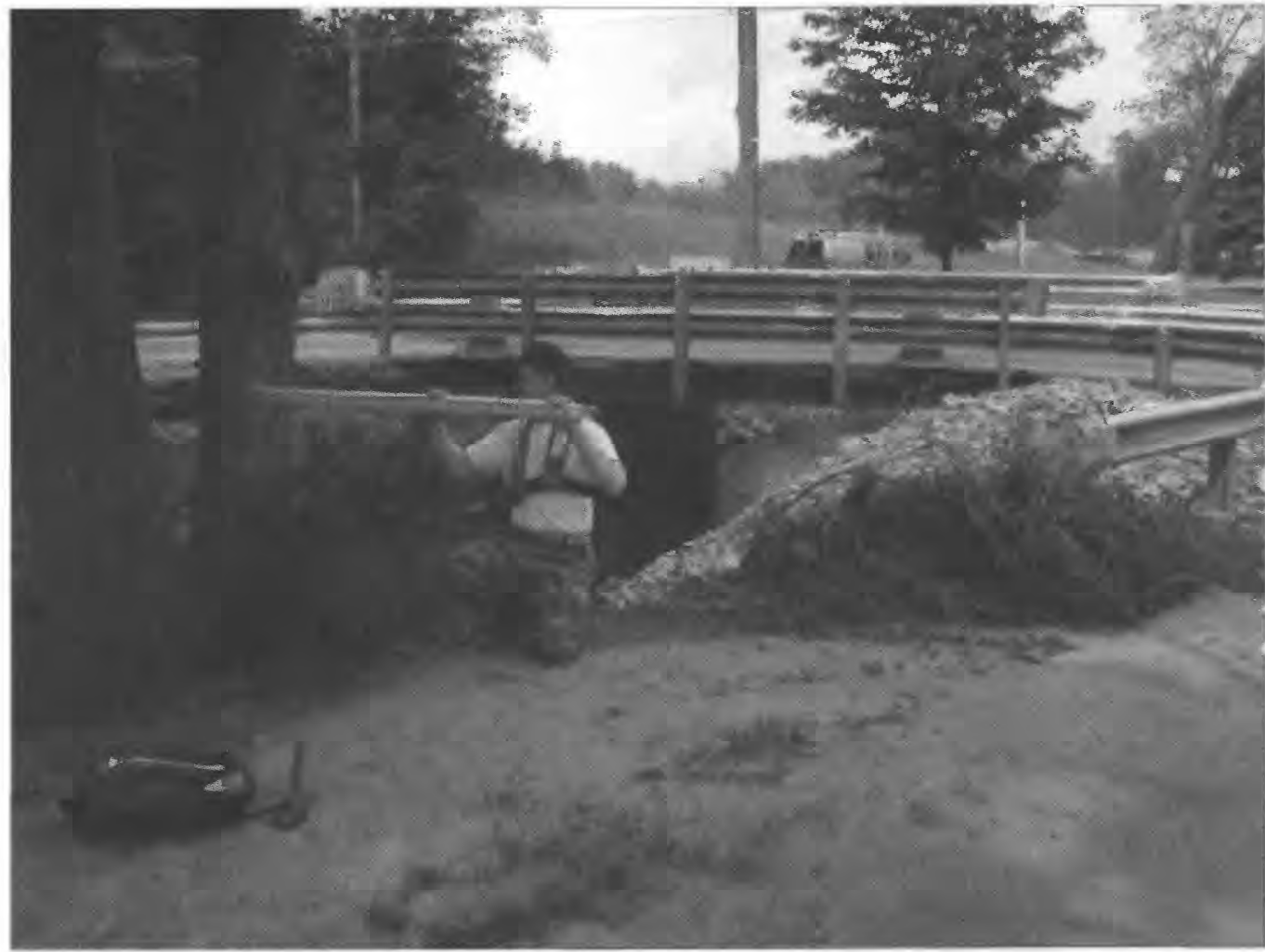

High-water mark W4.3 is a good debris line on 15-inch-diameter maple tree, 40 feet upstream from bridge, on right bank, and 3.5 feet above ground, at elevation 616.9 feet above sea level.

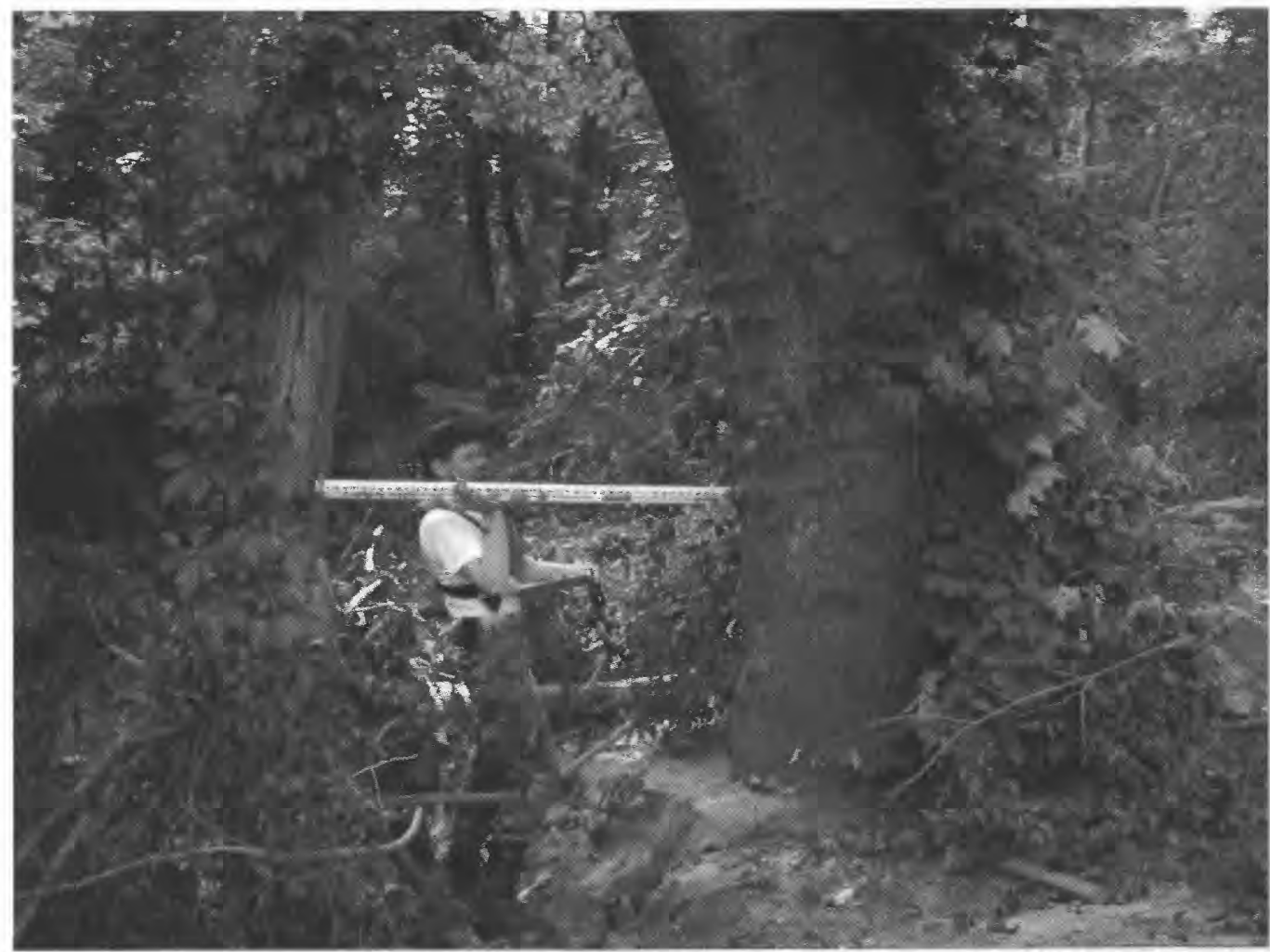

High-water mark W4.4 is a seed line on 40 -inch-diameter sycamore tree, 32 feet upstream from bridge on left bank, and 4.8 feet above ground on bank side of river, at elevation 616.3 feet above sea level. 


\section{SITE DESCRIPTION}

Site W5: Wallkill River at West Mountain Road at Sparta, N.J.

Site Location: Bridge on Station Road, Lat 4103'14" long 74³7'20", NAD 1927.

Sparta Township, Sussex County, New Jersey, Community 340535

Franklin USGS 7.5' Topographic Quadrangle

High-Water Marks: Four high-water marks were flagged: 1 good mud line, 1 unrated cut bank, and 2 poor seed and debris lines.

Photos of each high-water mark are attached. See field notes for GPS readings at each mark, filed at USGS office in West Trenton, N.J.

High-water marks flagged and photos taken by T.J. Reed and R.W. Edwards on September 12, 2000. Surveying was completed on October $31,2000$.

High-water-mark elevations were surveyed from benchmark T14.

New State Route 15 and rerouted County Route 517 are shown on the map below but are not shown on the latest 1971 photorevised maps currrently in publication.

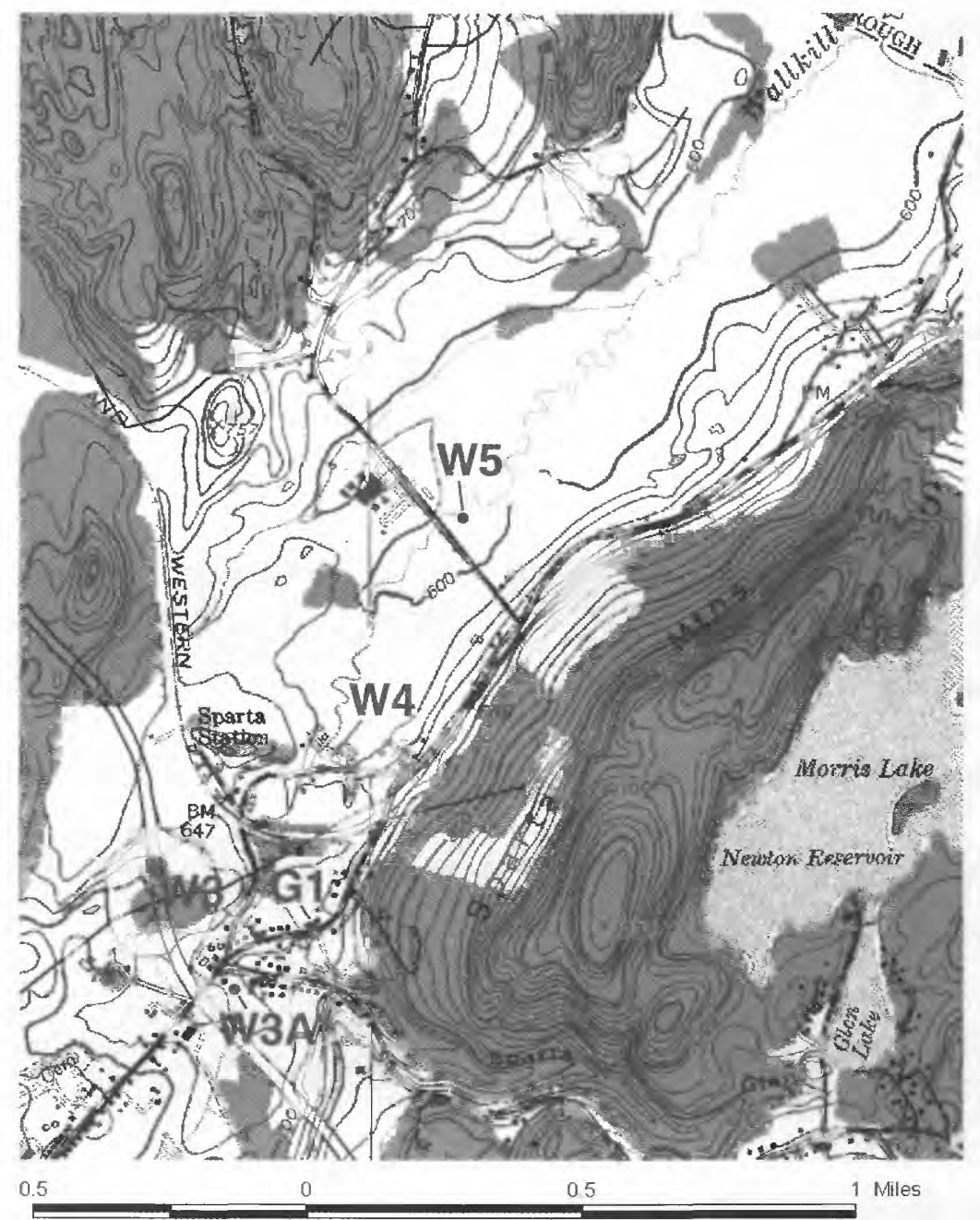

Newton East/Franklin quad map showing location of site W5, Wallkill River at West Mountain Road at Sparta, N.J. 
Site W5, Wallkill River at West Mountain Road at Sparta, N.J.

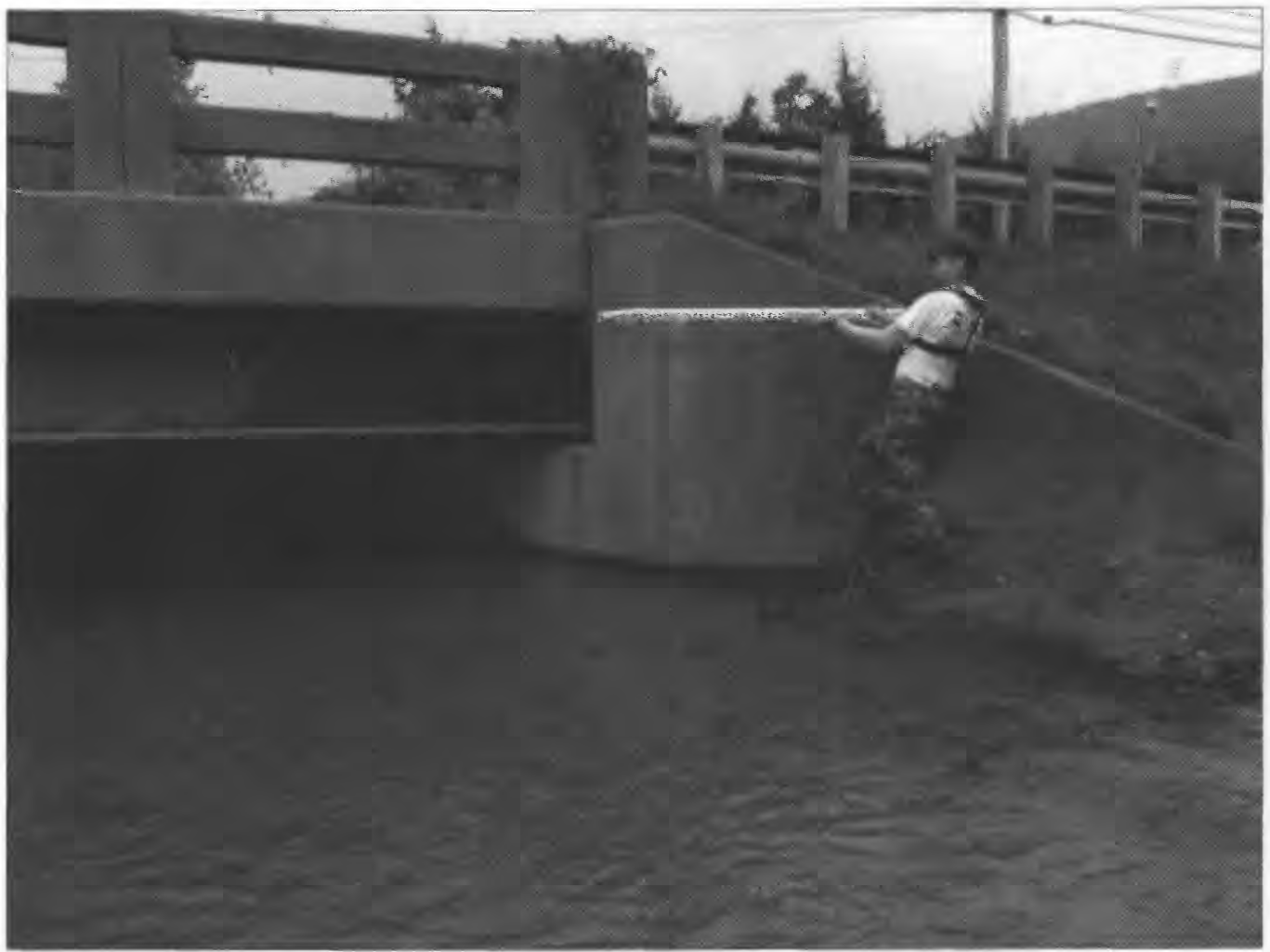

High-water mark W5.1 is a poor debris line on 12-inch-diameter tree, 30 feet downstream from bridge, on left bank, and 5.5 feet above streambed, at elevation 595.3 feet above sea level. (Mark maybe affected by pileup.)

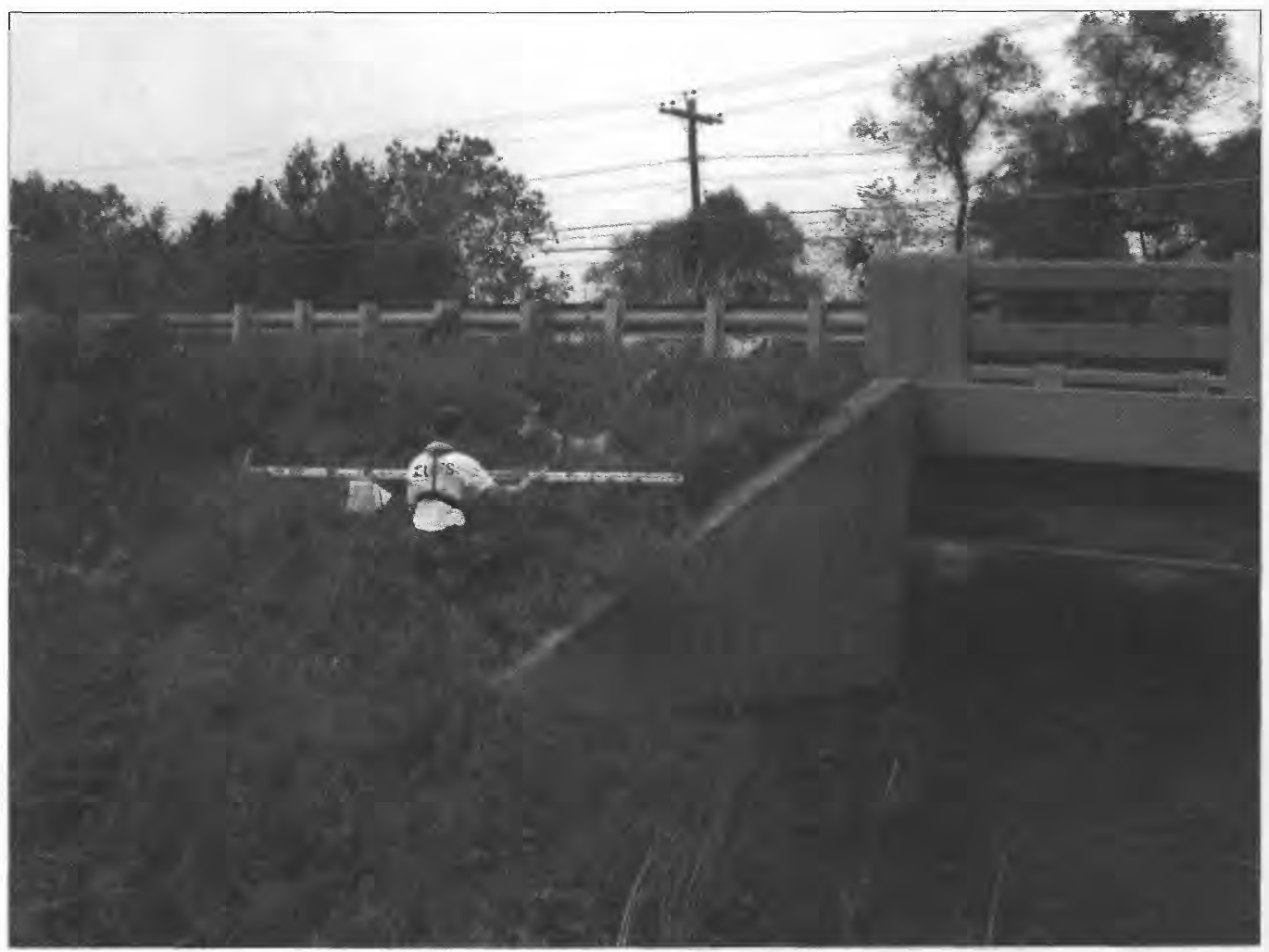

High-water mark W5.2 is a poor seed line on 10-inch-diameter rotted tree stump, 40 feet downstream from bridge on right bank, and 2.4 feet above ground, at elevation 593.6 feet above sea level. 
Site W5, Wallkill River at West Mountain Road at Sparta, N.J.

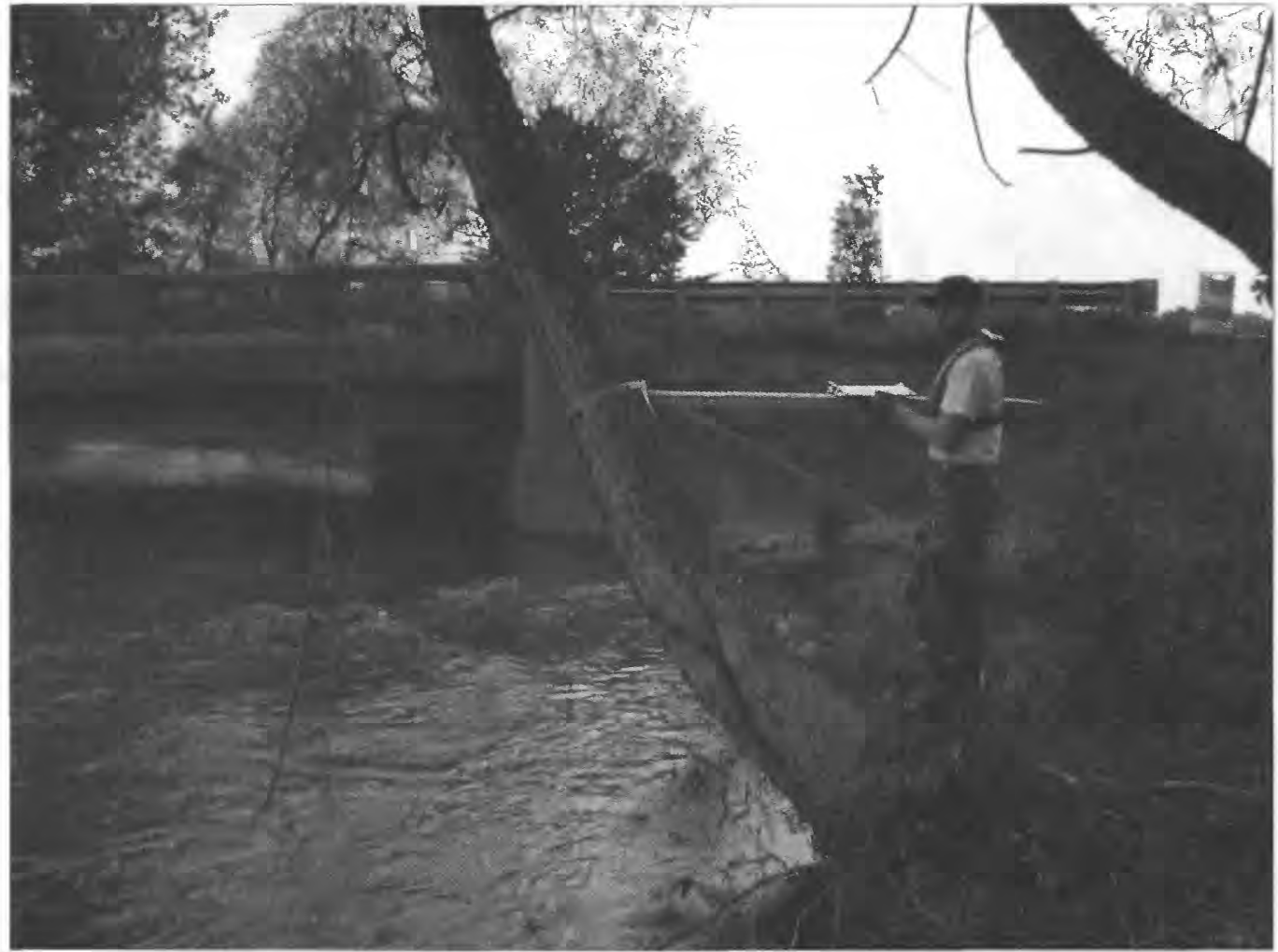

High-water mark W5.3 is a poor debris line on 12-inch-diameter tree, 30 feet downstream from bridge, on left bank, and 5.5 feet above streambed, at elevation 595.3 feet above sea level. (Mark maybe affected by pileup.)

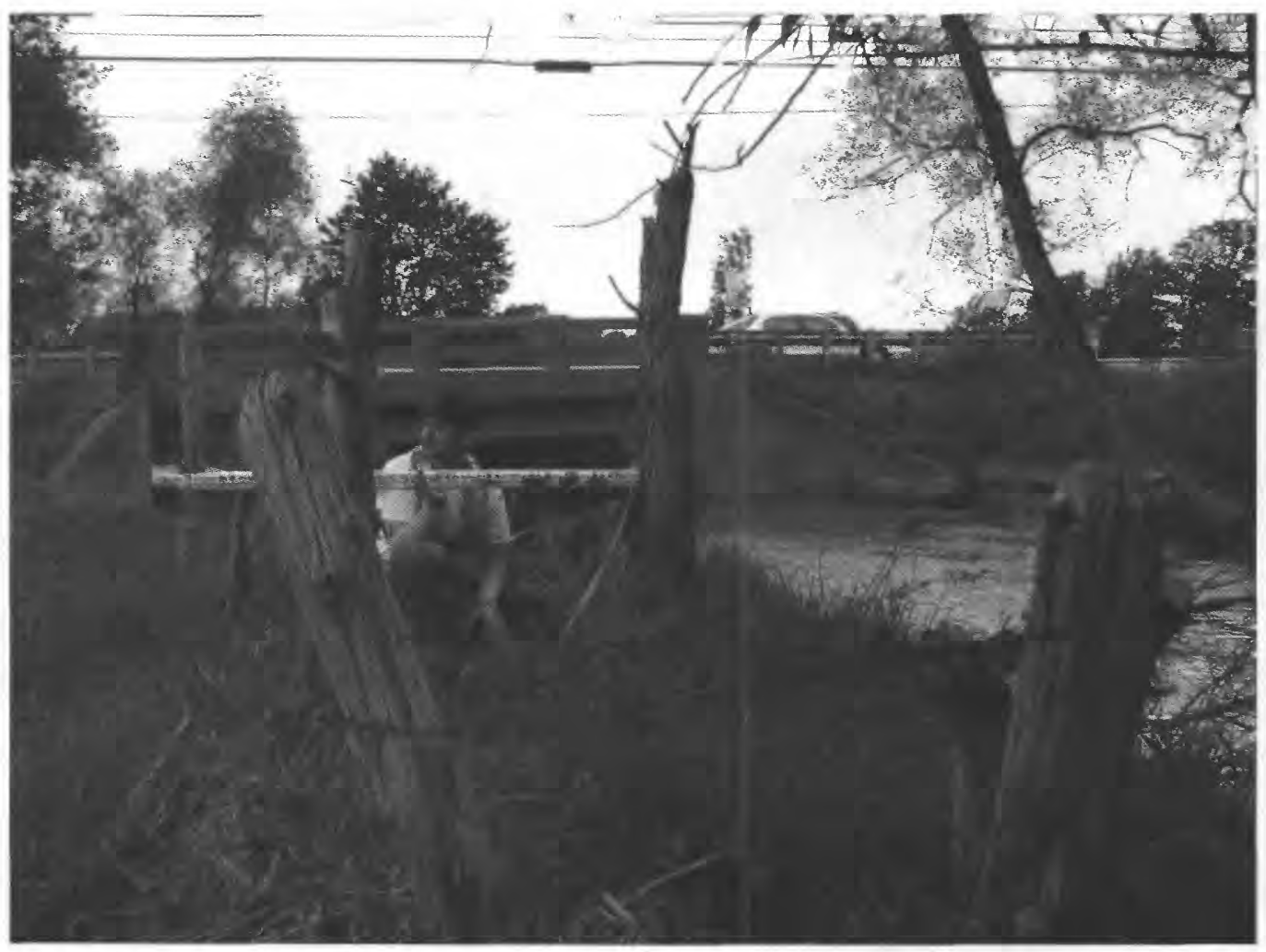

High-water mark W5.4 is a poor seed line on 10-inch-diameter rotted tree stump, 40 feet downstream from bridge on right bank, and 2.4 feet above ground, at elevation 593.6 feet above sea level. 
Site W5, Wallkill River at West Mountain Road at Sparta, N.J.

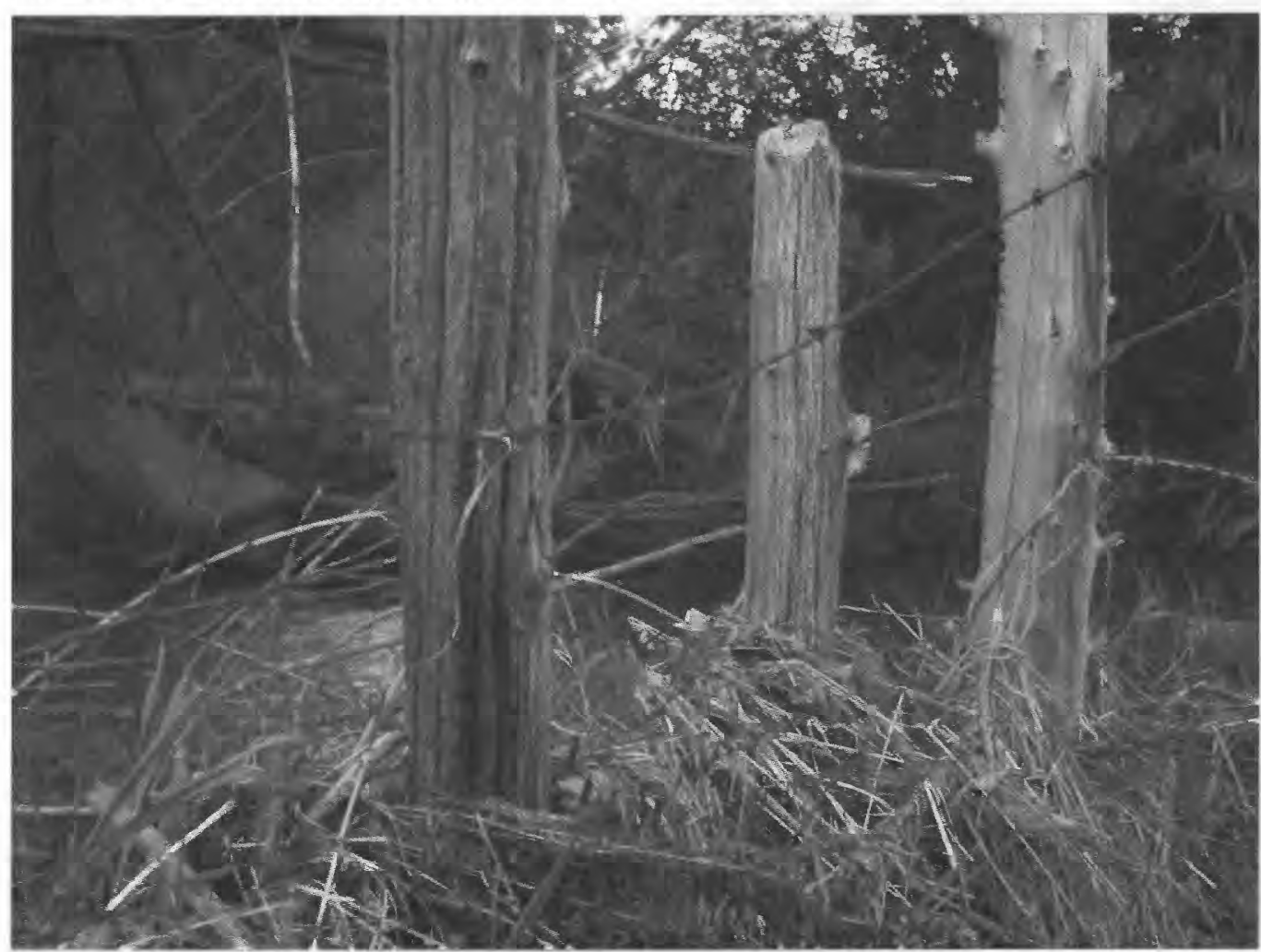

Barbed-wire fence downstream right bank near high-water mark W5.4. Debris caught on lower wire but not on top wire; however, high-water mark W5.4 on nearby tree is higher than the upper wire. 


\section{SITE DESCRIPTION}

Site W6: Wallkill River at Brook Flat Road at Ogdensburg, N.J.

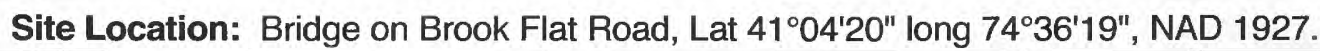

Ogdensburg Borough, Sussex County, New Jersey, Community 340454

Franklin USGS 7.5' Topographic Quadrangle

High-Water Marks: Four high-water marks were flagged: 3 excellent mud lines, 1 excellent seed/mud line.

Photos of each high-water mark are attached. See field notes for GPS readings at each mark, filed at USGS office in West Trenton, N.J.

High-water marks flagged and photos taken by T.J. Reed and R.W. Edwards on September 12, 2000. Surveying was completed on October 26, 2000.

High-water-mark elevations were surveyed from FEMA reference mark RM 3. A description and map locating the reference mark is available.

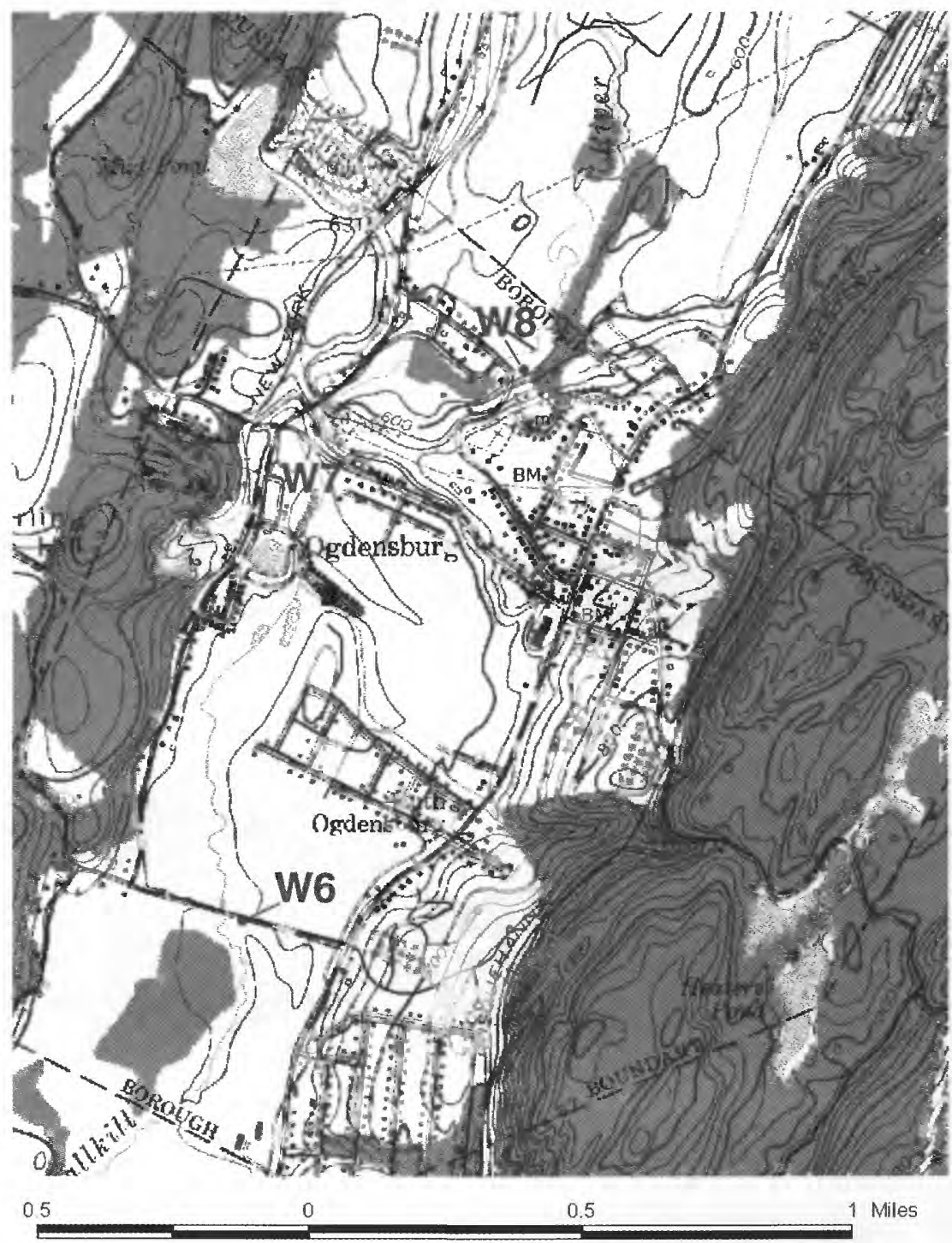

Franklin quad map showing location of site W6, Wallkill River at Flat Brook Road at Ogdensburg, N.J. 
Site W6 Wallkill River at Brook Flat Road at Ogdensburg, N.J.

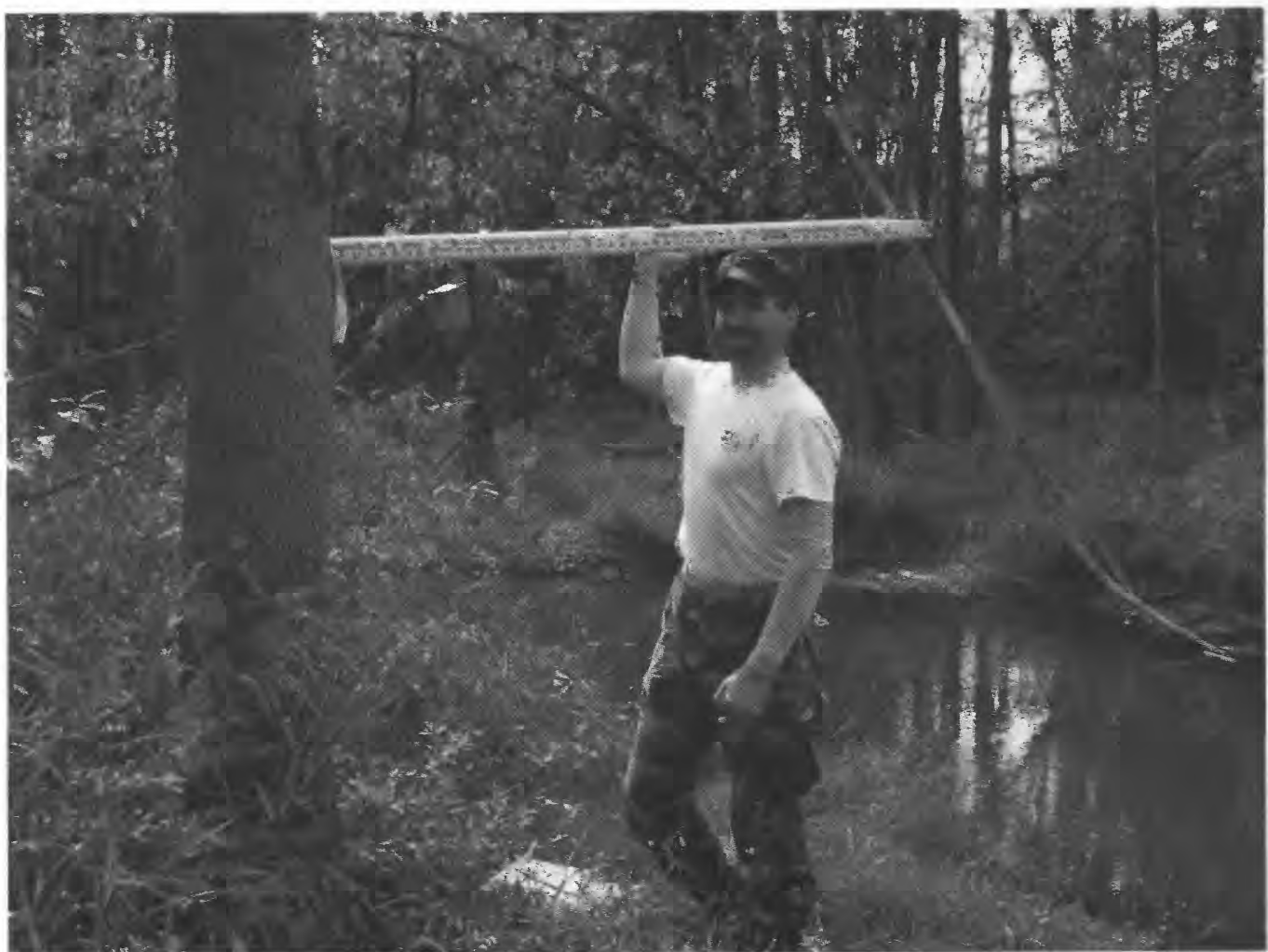

High-water mark W6.1 is an excellent mud/seed line on 12-inch-diameter ash tree, 25 feet upstream from bridge on right bank, 5.5 feet above ground, and marked by survey nail, $\mathbf{5 7 5 . 5}$ feet above sea level.

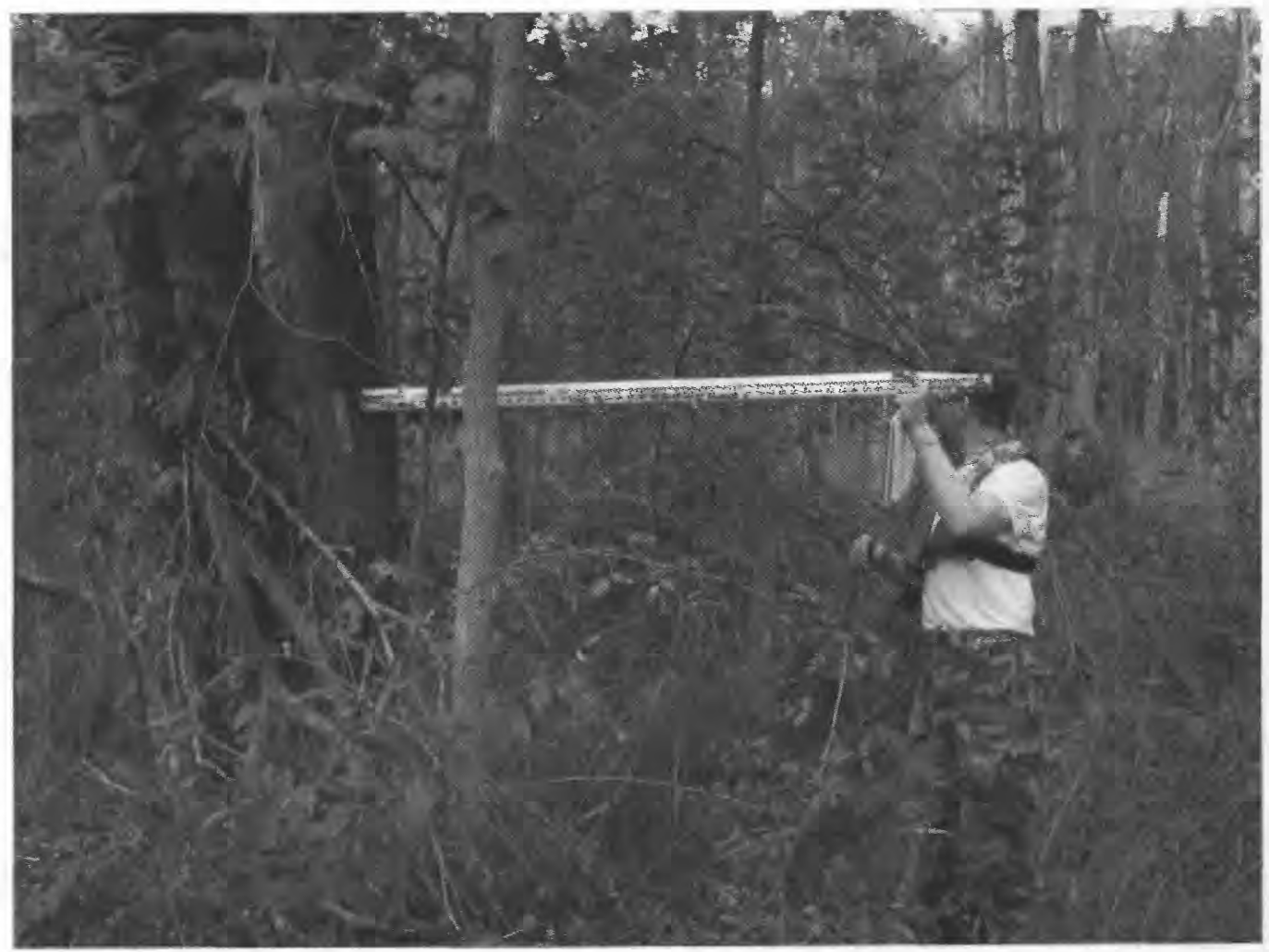

High-water mark W6.2 is an excellent mud line on 12-inch-diameter tree, 35 feet downstream from bridge on right bank, 5.8 feet above ground, and marked with survey nail, 575.5 feet above sea level. 
Site W6 Wallkill River at Brook Flat Road at Ogdensburg, N.J.

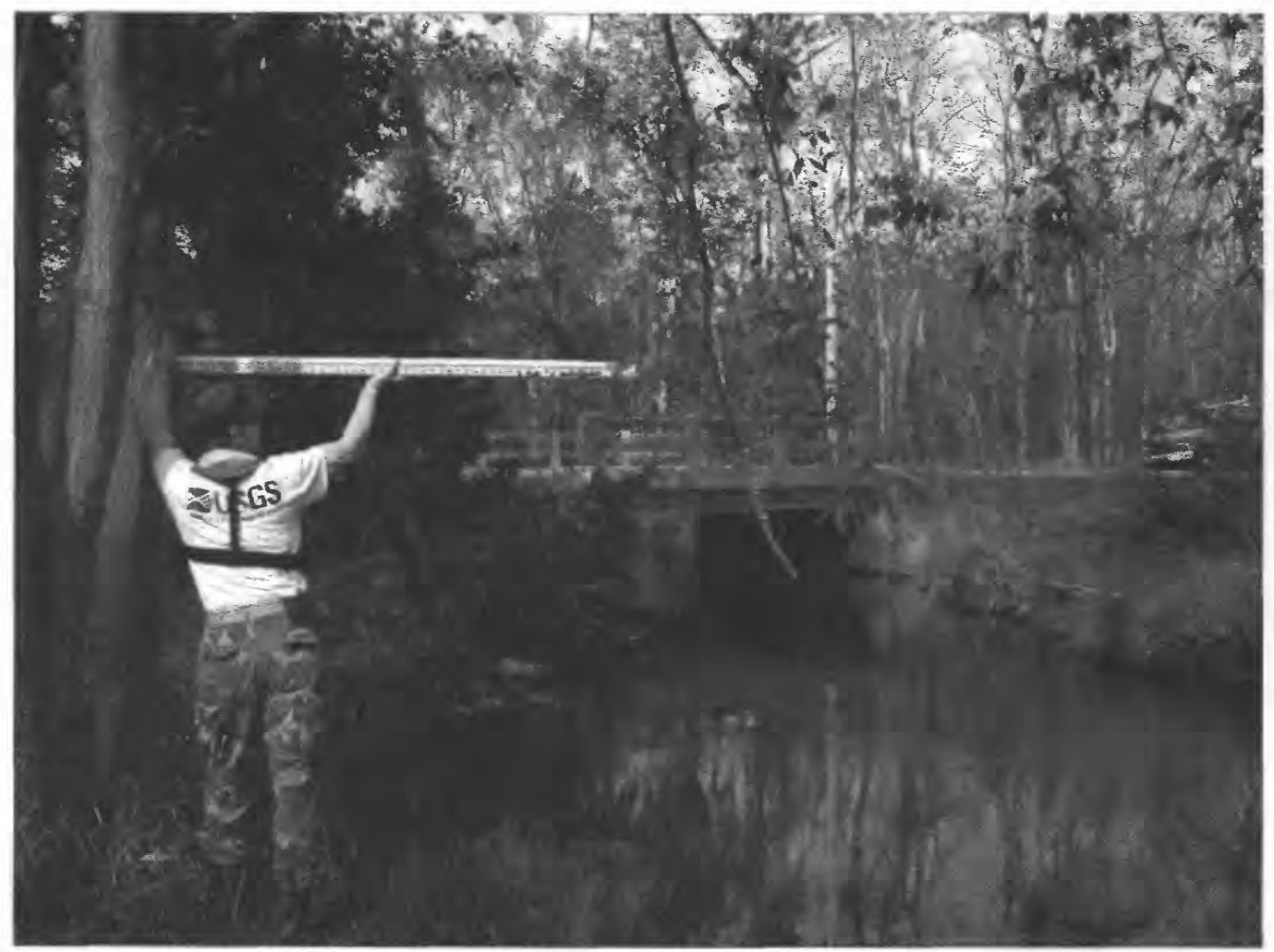

High-water mark W6.3 is an excellent mud line on 10-inch-diameter tree, 54 feet upstream from bridge, on left bank, 6.6 feet above ground, and marked by survey nail, 575.5 feet above sea level.

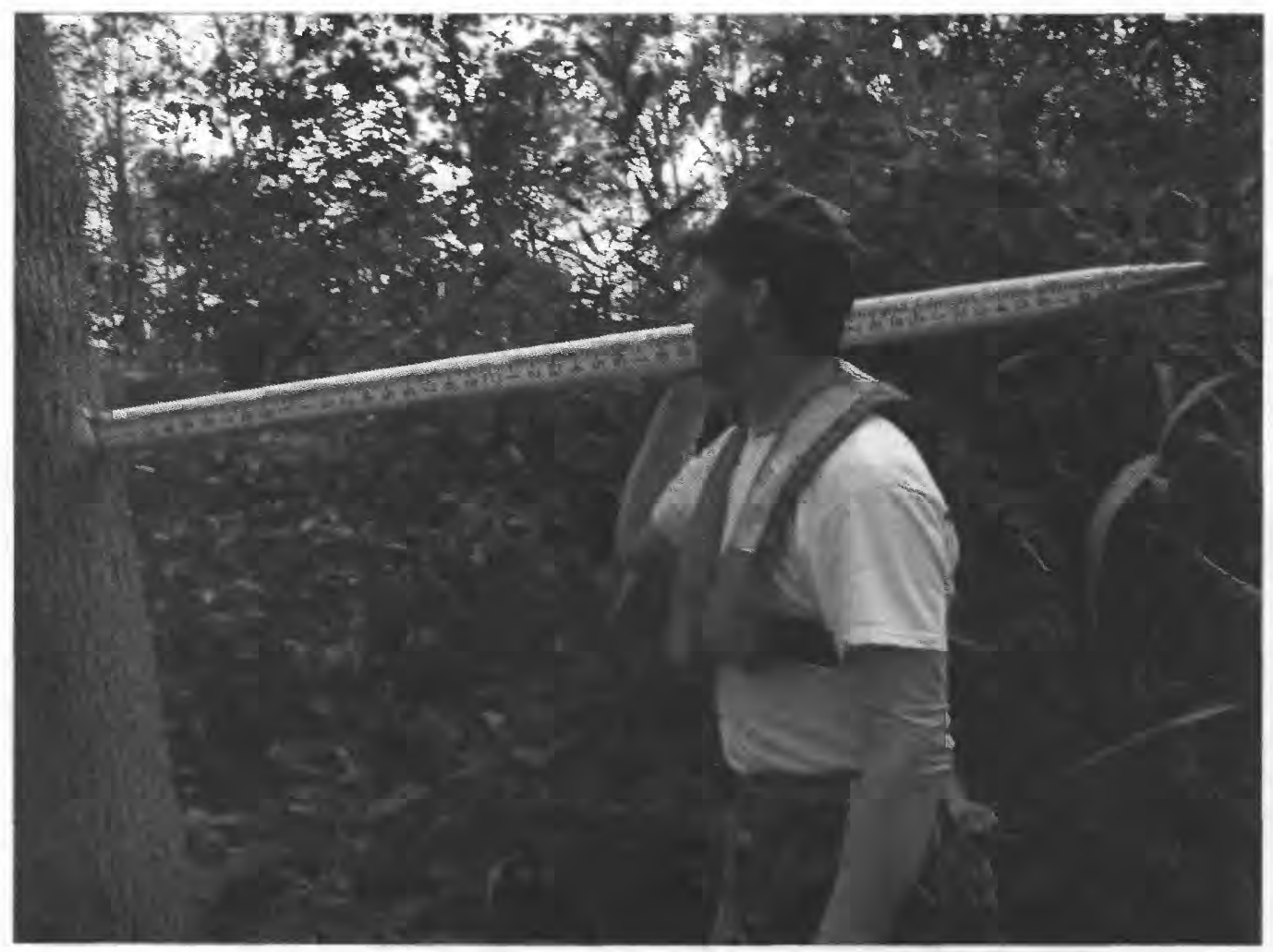

High-water mark W6.3 is an excellent mud line on 12-inch-diameter tree, 20 feet downstream from bridge on left bank, and 5.4 feet above ground. Marked with a survey nail, 575.5 feet above sea level. 


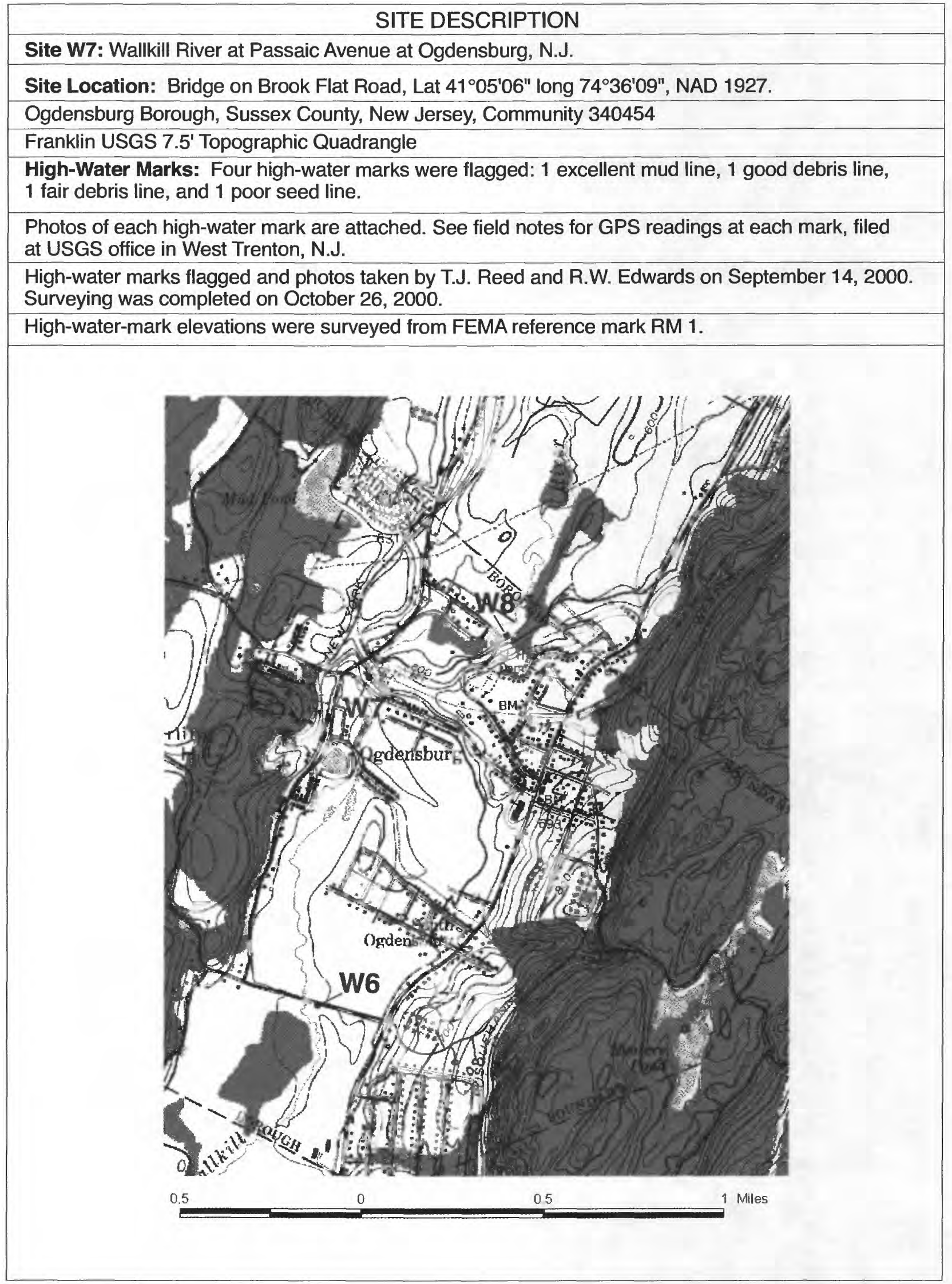

Franklin quad map showing location of site W7, Wallkill River at Passaic Avenue at Ogdensburg, N.J. 
Site W7 Wallkill River at Passaic Avenue at Ogdensburg, N.J.

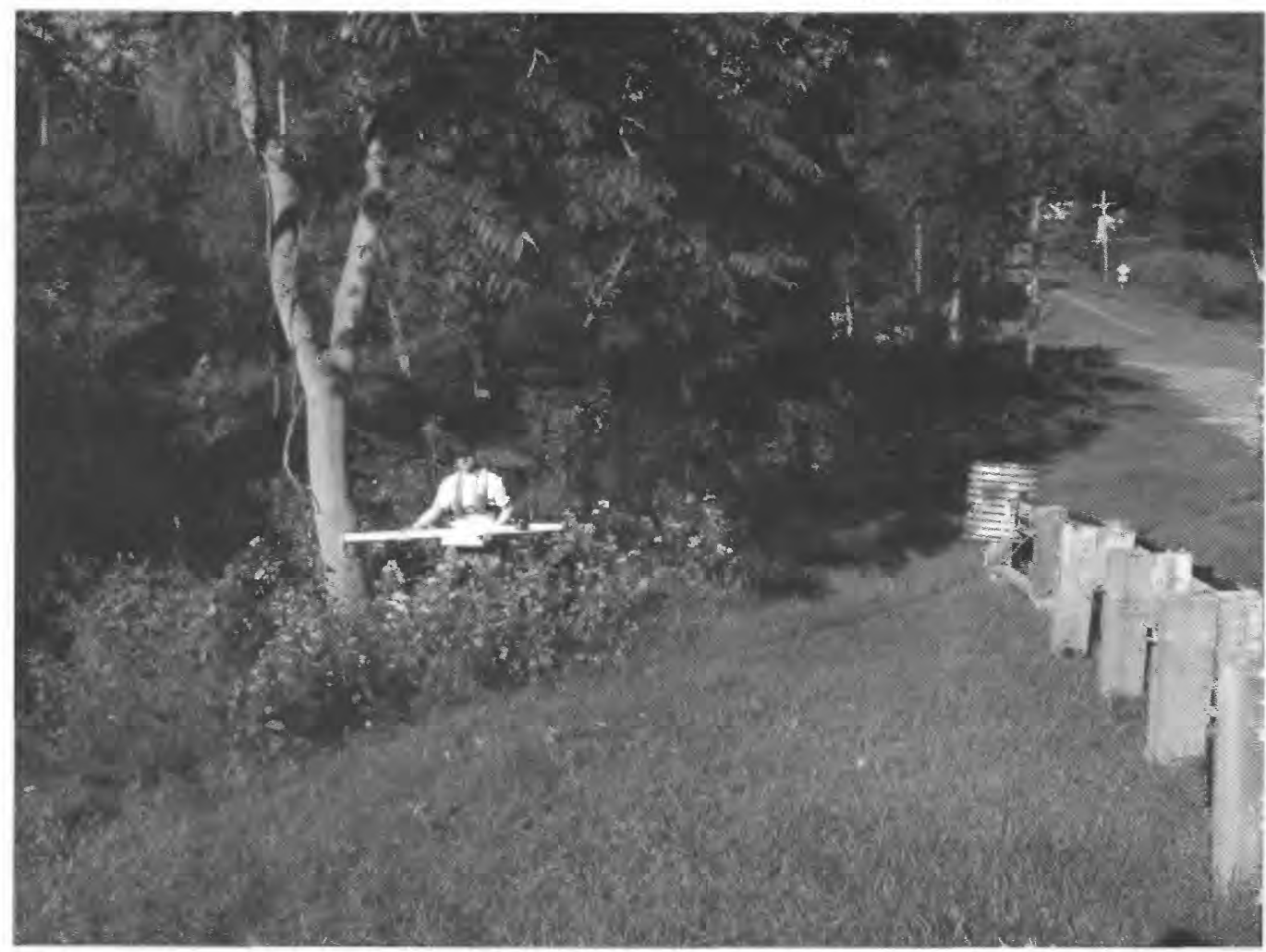

High-water mark W7.1 is an excellent mud line on 14-inch-diamter ash tree, 20 feet upstream from bridge on left bank, 300 feet to left of river and 3.9 feet above ground, at elevation 571.2 feet above sea level.

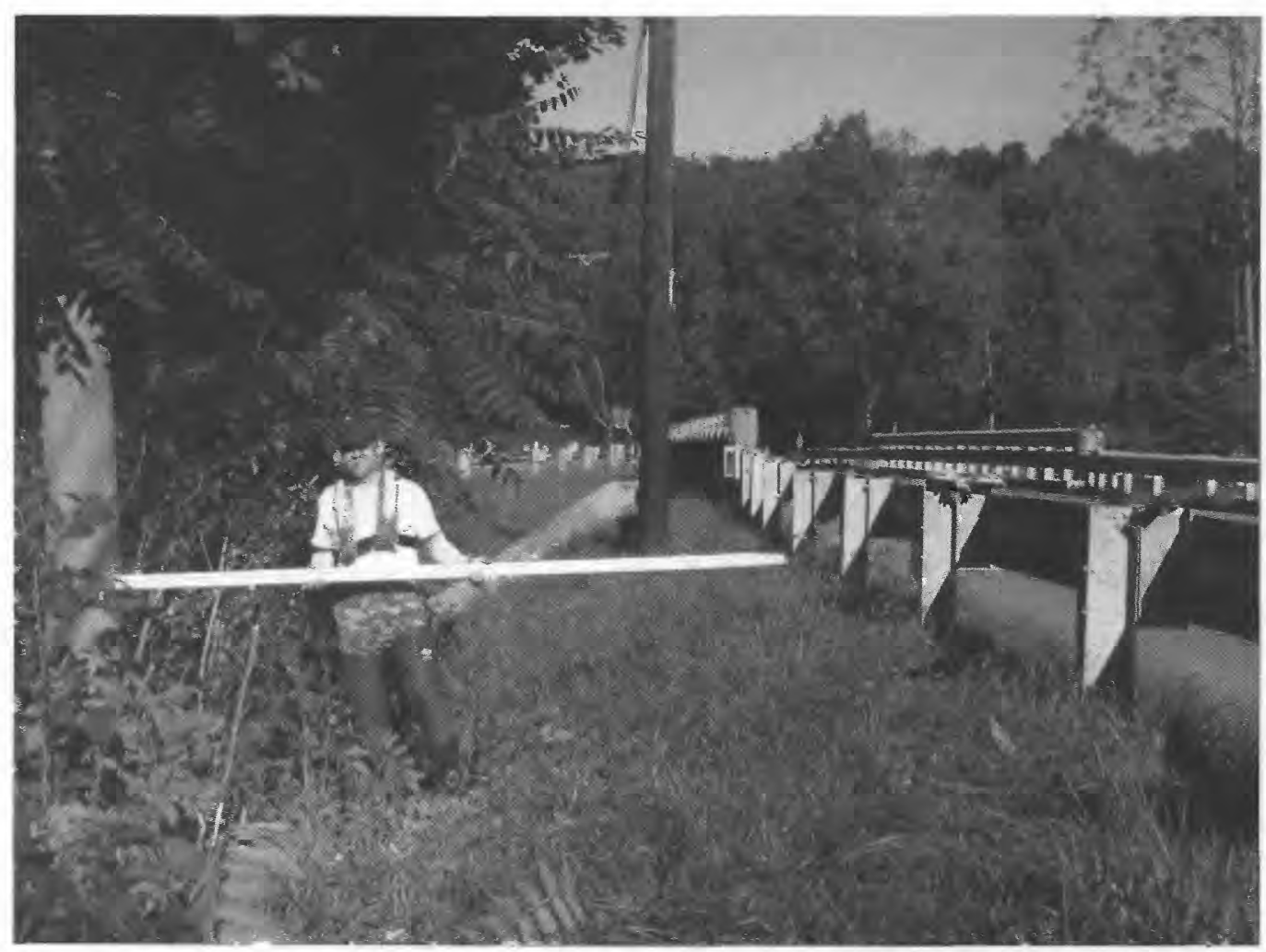

High-water mark W7.2 is a good mud line on 12-inch-diameter black gum tree, 10 feet upstream from bridge on right bank, 20 feet to right of Wallkill River and 5.1 feet above ground, at elevation 571.1 feet above sea level. 
Site W7 Wallkill River at Passaic Avenue at Ogdensburg, N.J.

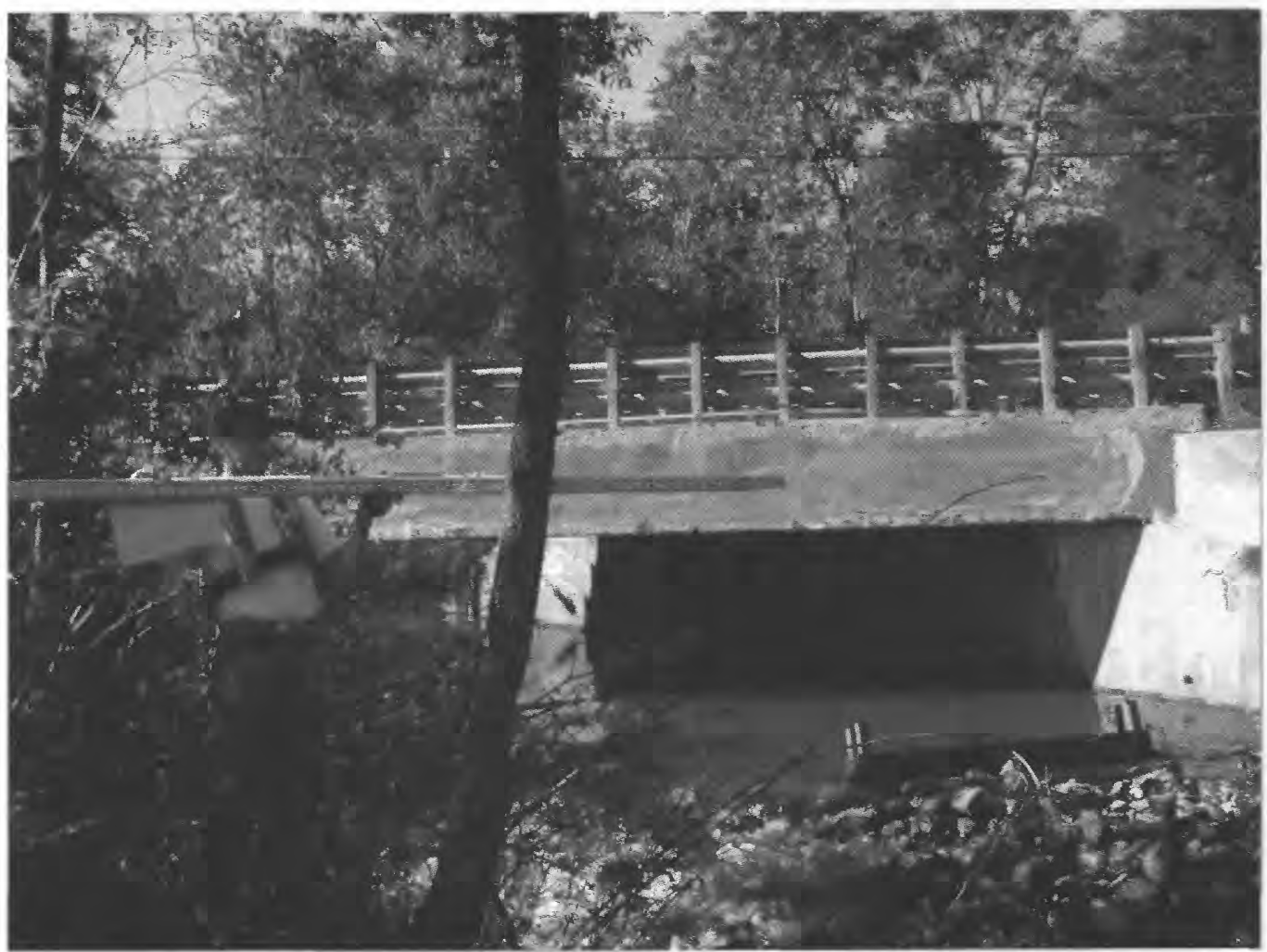

High-water mark W7.3 is a fair debris line on 6-inch-diameter cherry tree, 30 feet downstream from bridge, on right bank, 5.1 feet above base of tree, at elevation 569.3 feet above sea level.

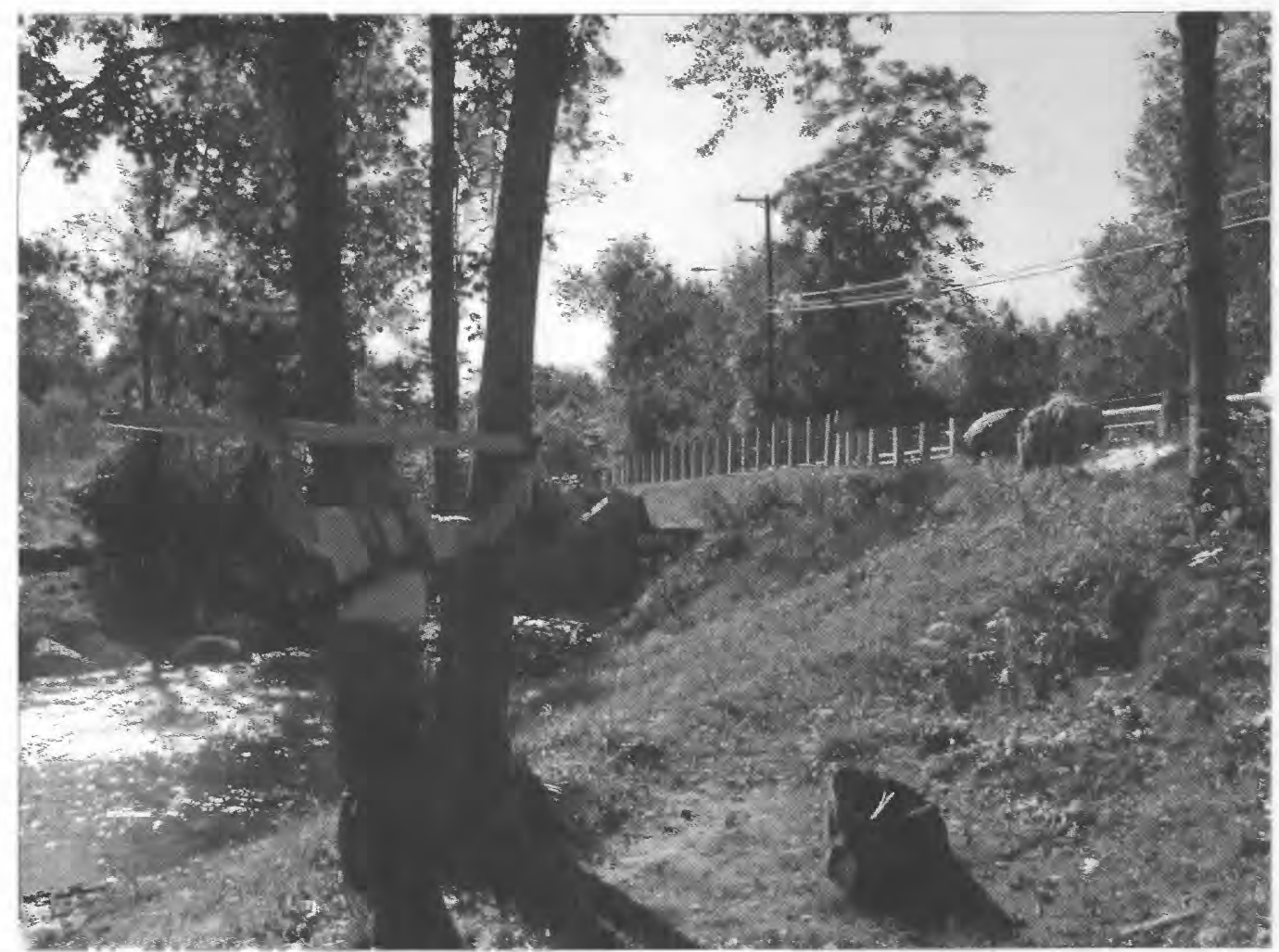

High-water mark W7.4 is a poor seed line on 9-inch-diameter tree, 35 feet downstream from bridge on left bank, and 5.7 feet above ground, at elevation 569.2 feet above sea level. 


\section{SITE DESCRIPTION}

Site W8: Wallkill River at Kennedy Avenue at Ogdensburg, N.J.

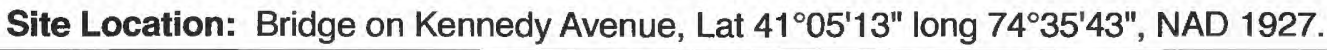

Ogdensburg Borough, Sussex County, New Jersey, Community 340454

Franklin USGS 7.5' Topographic Quadrangle

High-Water Marks: Five high-water marks were flagged: 2 fair mud lines, 2 fair debris lines, and 1 good eyewitness account of peak on homeowner's lawn.

Photos of each high-water mark are attached. See field notes for GPS readings at each mark, filed at USGS office in West Trenton, N.J.

High-water marks flagged and photos taken by T.J. Reed and R.W. Edwards on, September 14, 2000. Surveying was completed on October $30,2000$.

High-water-mark elevations were surveyed from benchmark RV65.

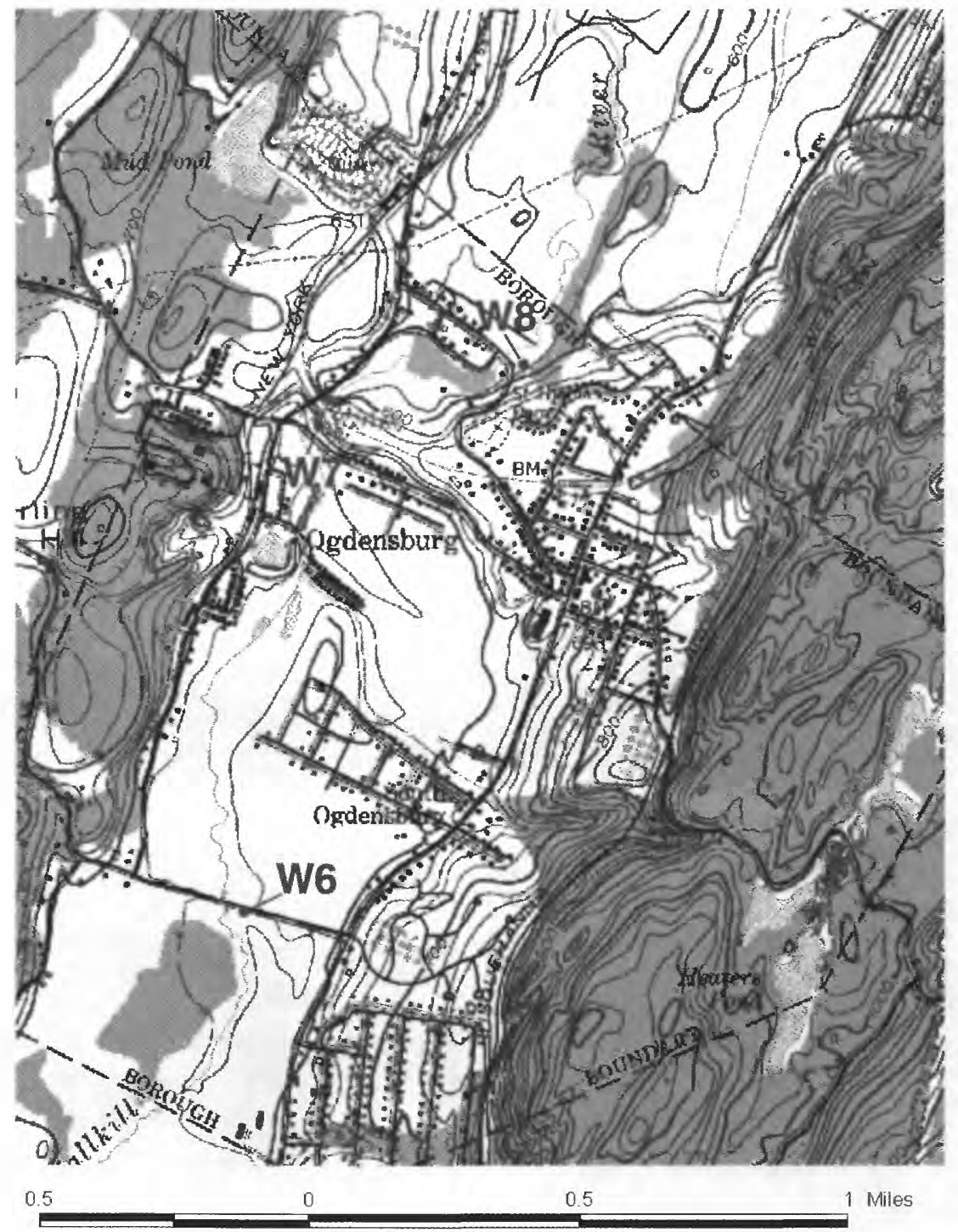

Franklin quad map showing location of site W8, Wallkill River at Kennedy Avenue at Ogdensburg, N.J. 
Site W8 Wallkill River at Kennedy Avenue at Ogdensburg, N.J.

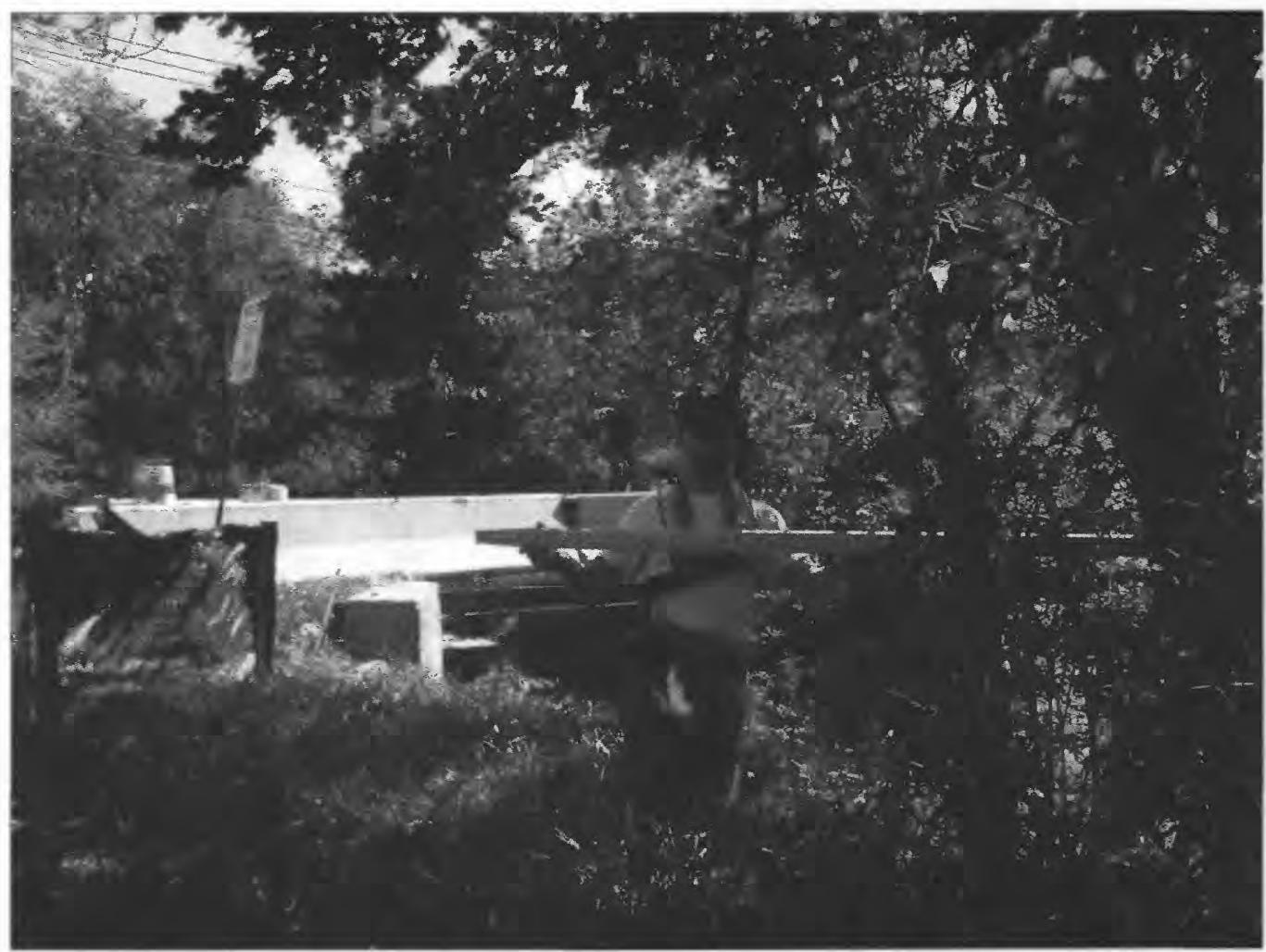

High-water mark W8.1 is a fair mud line on 14-inch-diameter tree, 32 feet upstream from bridge, on left bank, and 3.4 feet above ground, at elevation 562.6 feet above sea level.

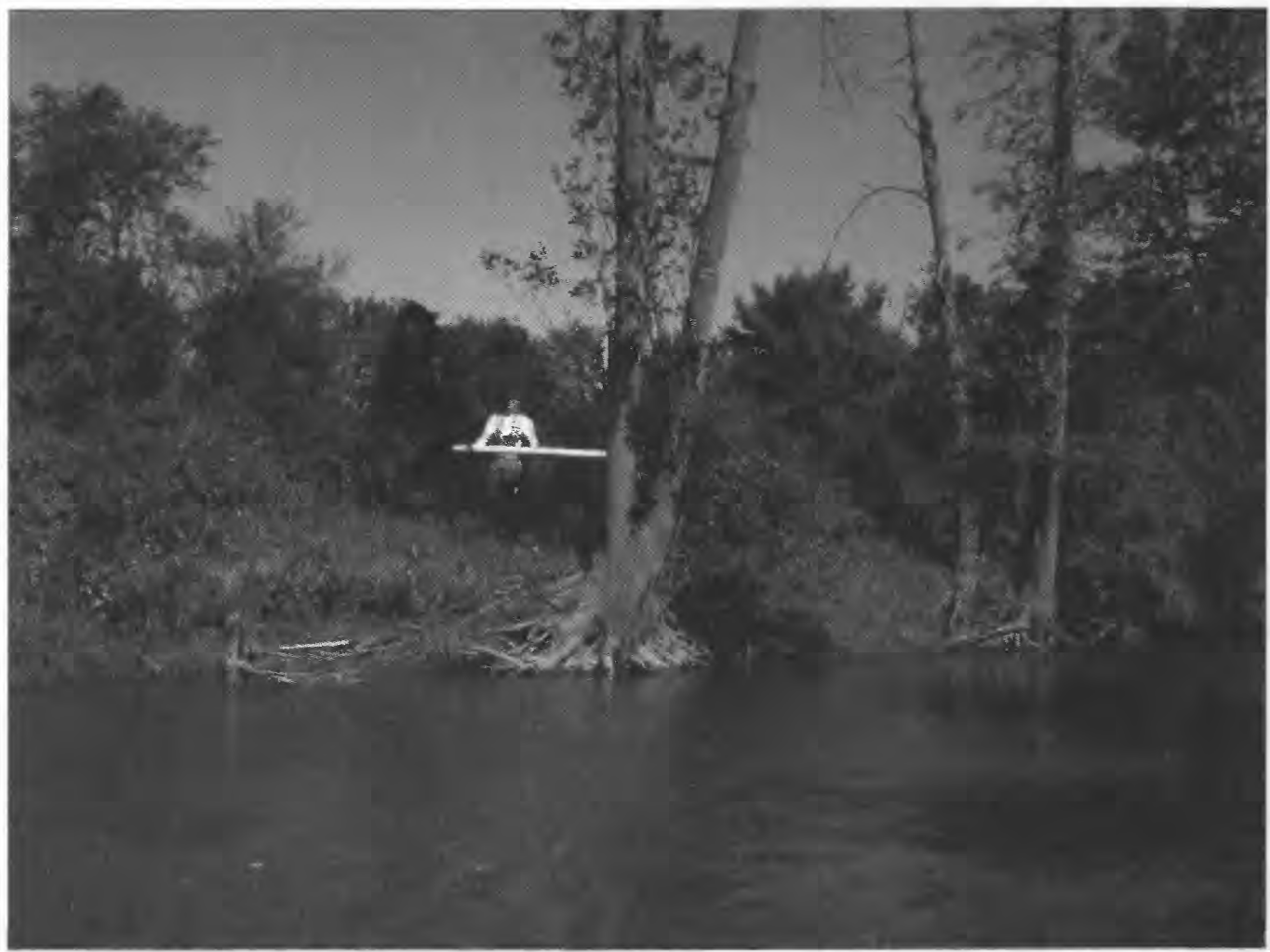

High-water mark W8.2 is a fair mud line on 12-inch-diameter tree, 50 feet downstream from bridge on left bank, and 3.7 feet above ground, on bank side of tree, at elevation 561.7 feet above sea level. 
Site W8 Wallkill River at Kennedy Avenue at Ogdensburg, N.J.

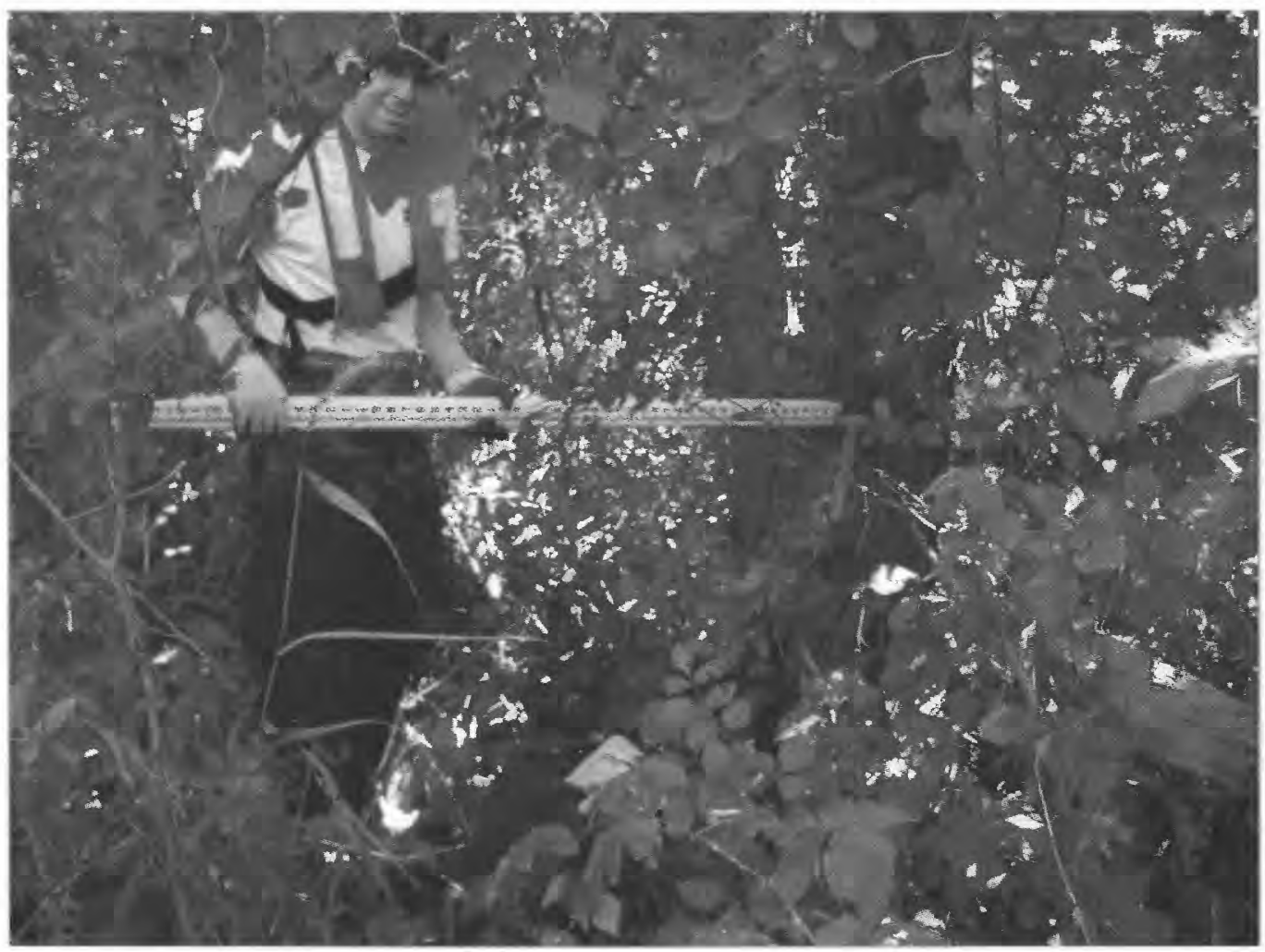

High-water mark W8.3 is a fair debris line on 14-inch-diameter tree, 60 feet downstream from bridge, on right bank, 3.0 feet above base of tree on bank side, at elevation 561.0 feet above sea level.

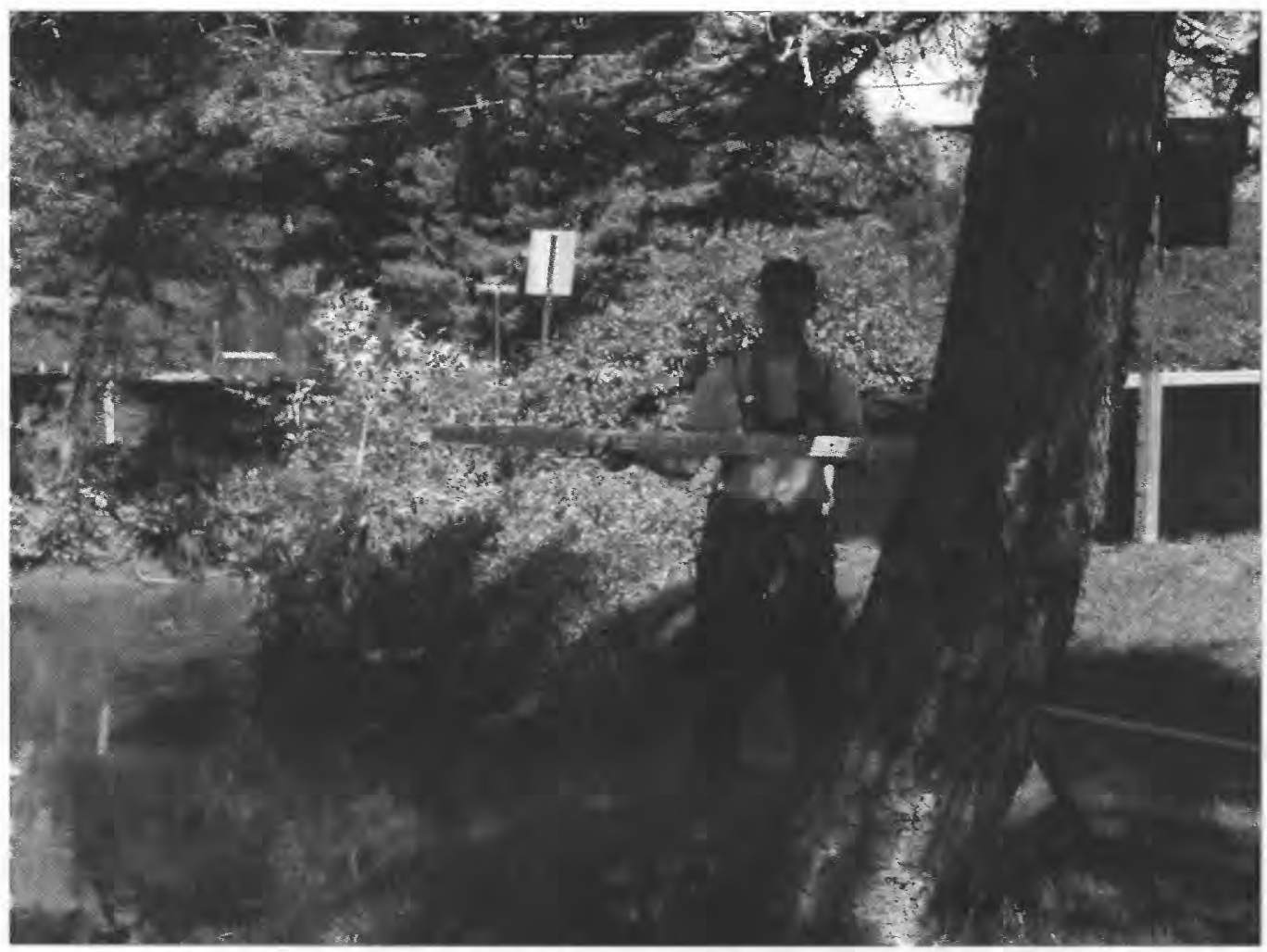

High-water mark W8.4 is a fair debris line on 20-inch-diameter pine tree, 20 feet upstream from bridge on right bank, and 44.4 feet above ground, at elevation 562.7 feet above sea level. 
Site W8 Wallkill River at Kennedy Avenue at Ogdensburg, N.J.

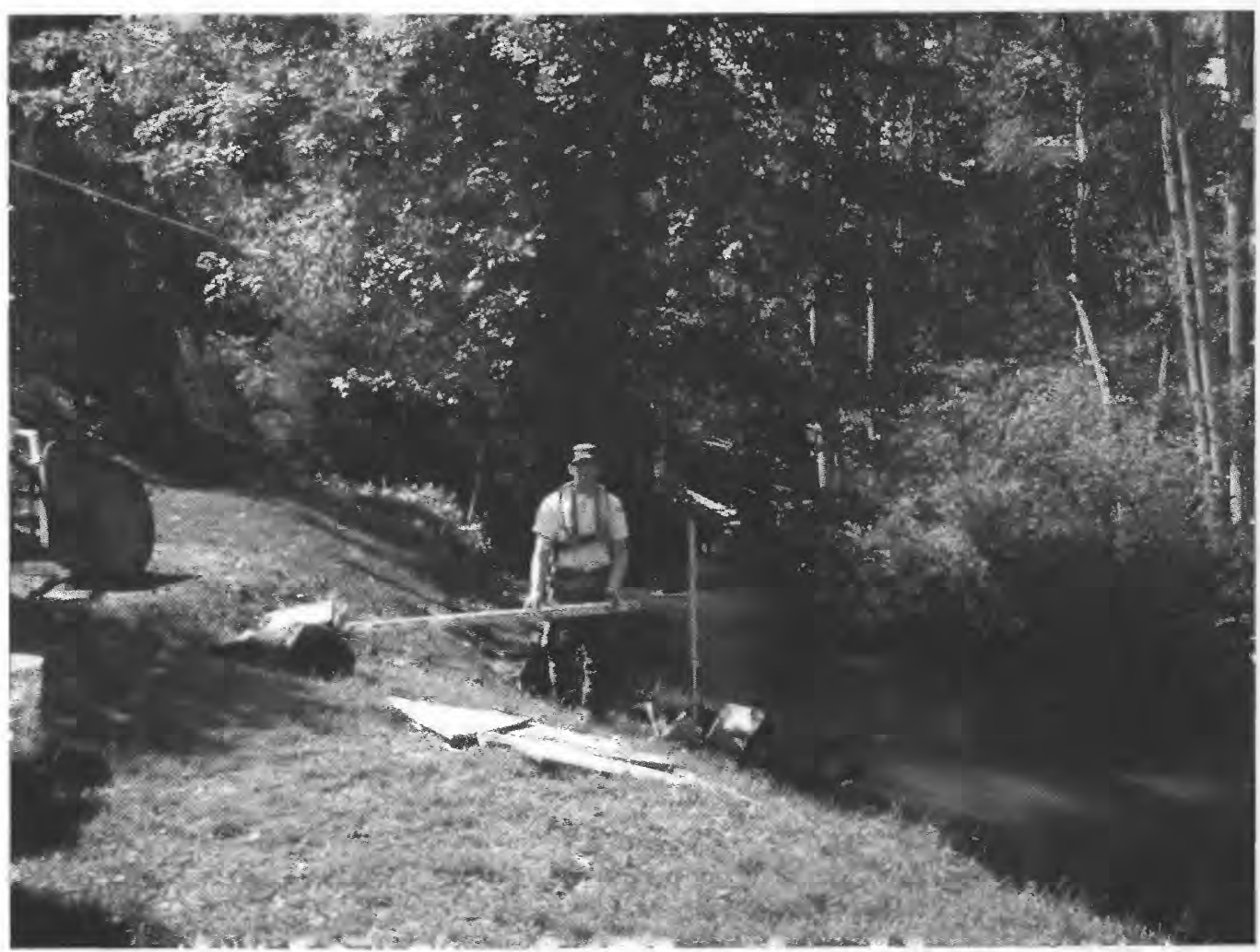

High-water mark W8.5 is a good observation of peak stage by homeowner. Marked by a wooden stake on dirt embankment, 100 feet upstream from bridge, on right bank, at elevation 563.5 feet above sea level. 


\section{SITE DESCRIPTION}

Site W9 (1367700): Wallkill River at outlet of Franklin Pond at Frankiln, N.J.

Site Location: Bridge on Franklin Avenue, Lat 41 ${ }^{\circ} 06^{\prime} 43^{\prime \prime}$ long 74³5'21", NAD 1927.

Ogdensburg Borough, Sussex County, New Jersey, Community 340449

Franklin USGS 7.5' Topographic Quadrangle

High-Water Marks: Six high-water marks were flagged: 1 good seed line, 1 good mud line, 3 fair debris lines, and 1 poor seed line.

Photos of each high-water mark are attached. See field notes for GPS readings at each mark, filed at USGS office in West Trenton, N.J.

High-water marks flagged and photos taken by T.J. Reed and R.W. Edwards on September 14, 2000. Surveying was completed on October 25, 2000.

High-water-mark elevations were surveyed from U.S. Coast and Geodetic Survey benchmark (Franklin 3) located at the site.

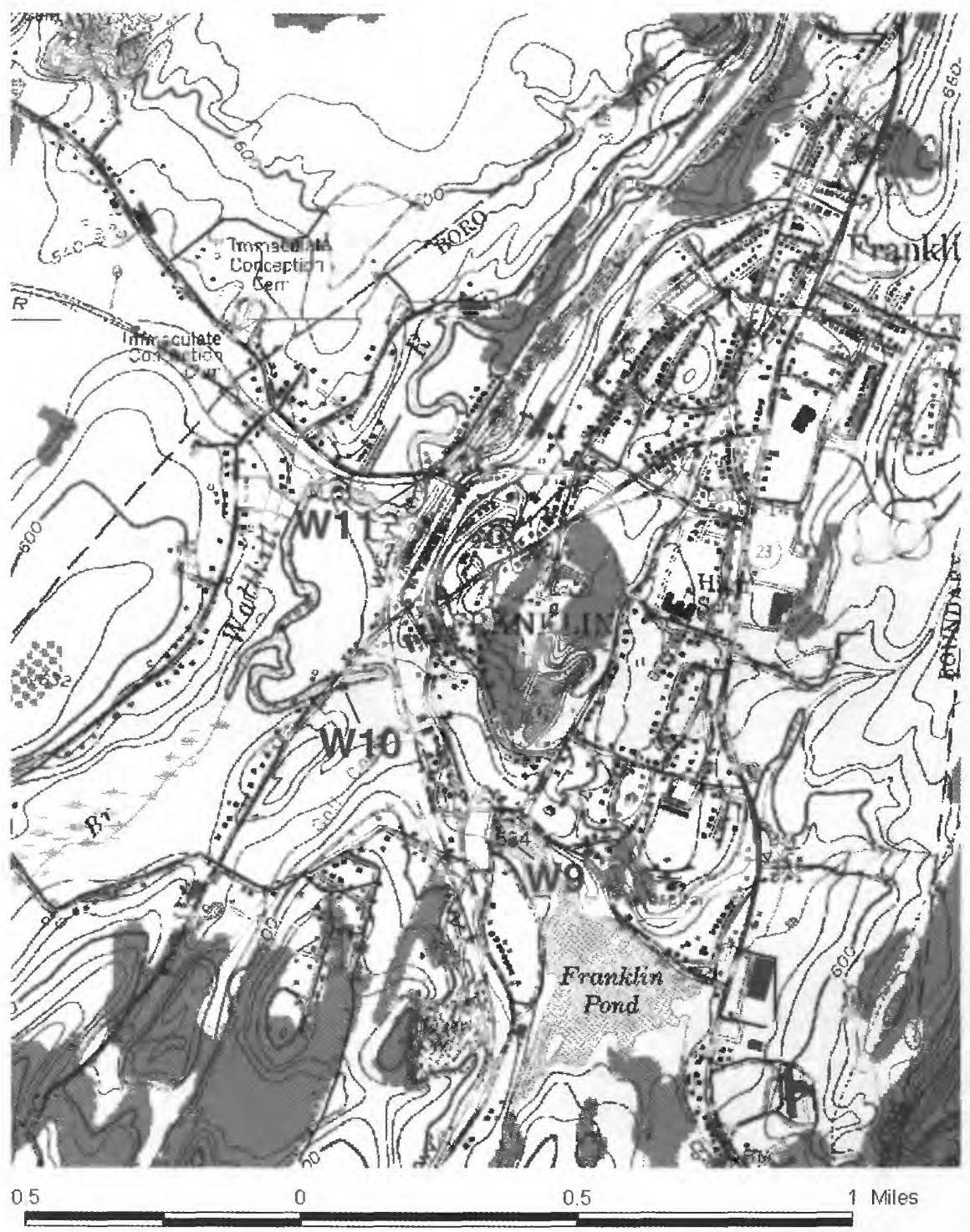

Franklin/Hamburg quad map showing location of site W9, Wallkill River at outlet of Franklin Pond at Franklin, N.J. 
Site W9 (01367700) Wallkill River at outlet at Franklin Pond at Franklin, N.J.

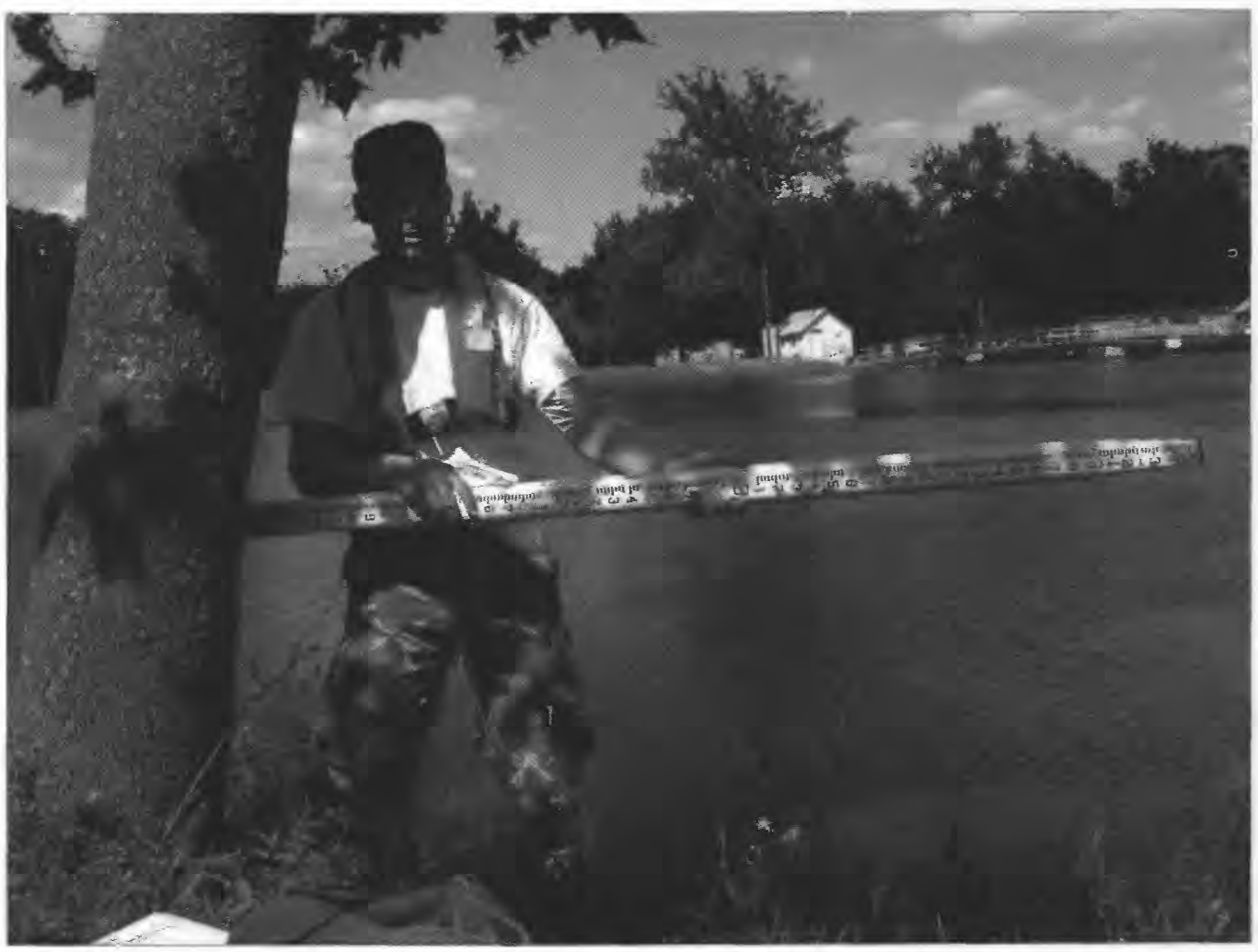

High-water mark W9.1 is a good seed line on 14-inch-diameter tree, 200 feet upstream from dam on left bank, 2.5 feet above ground and 3.6 feet above current lake level, at elevation 535.0 feet above sea level.

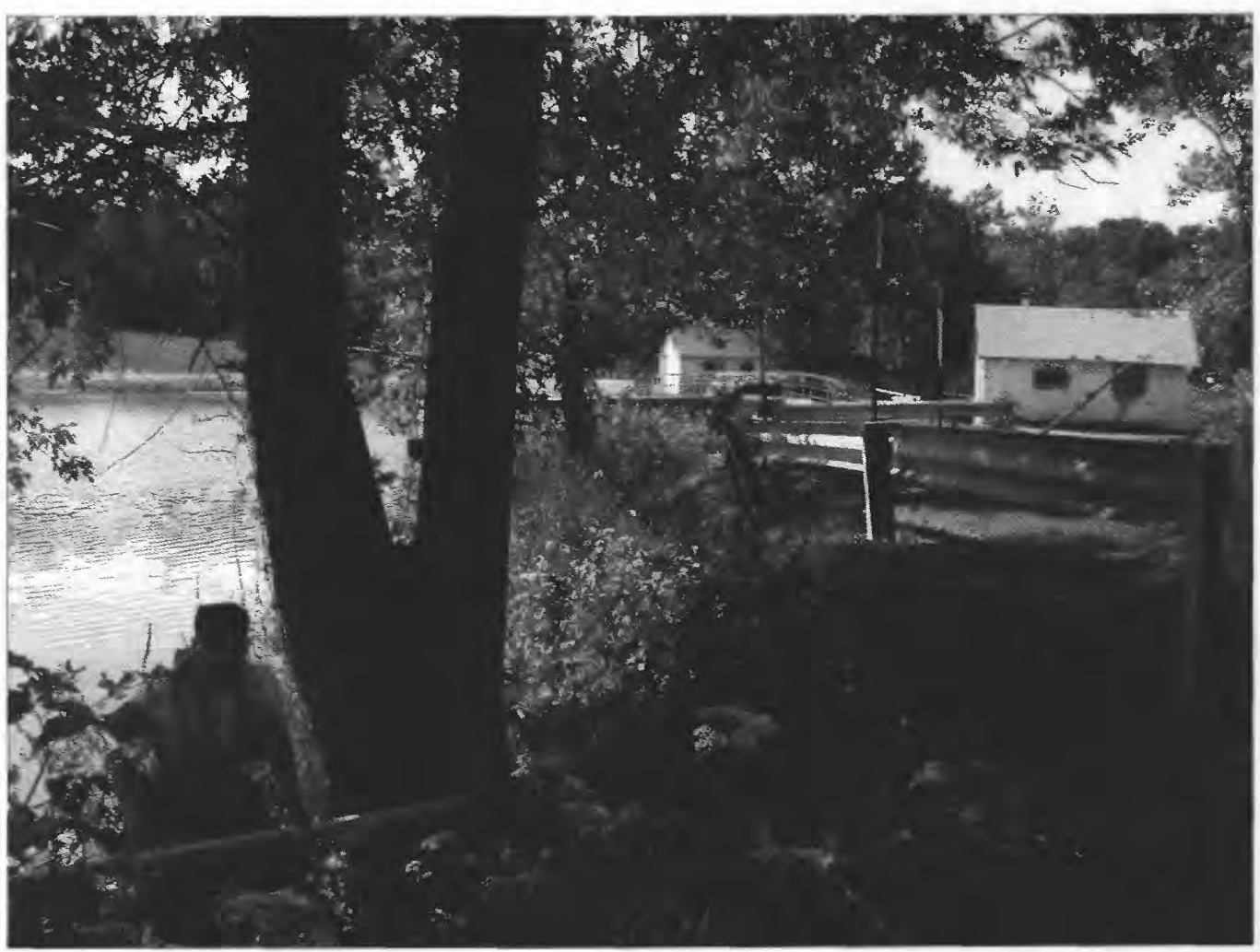

High-water mark W9.2 is a good mud line on 2.5-foot-diameter maple tree, 25 feet upstream from dam on right bank, and 1.6 feet above ground and 3.9 feet above current lake, at elevation 535.0 feet above sea level. 
Site W9 (01367700) Wallkill River at outlet at Franklin Pond at Franklin, N.J.

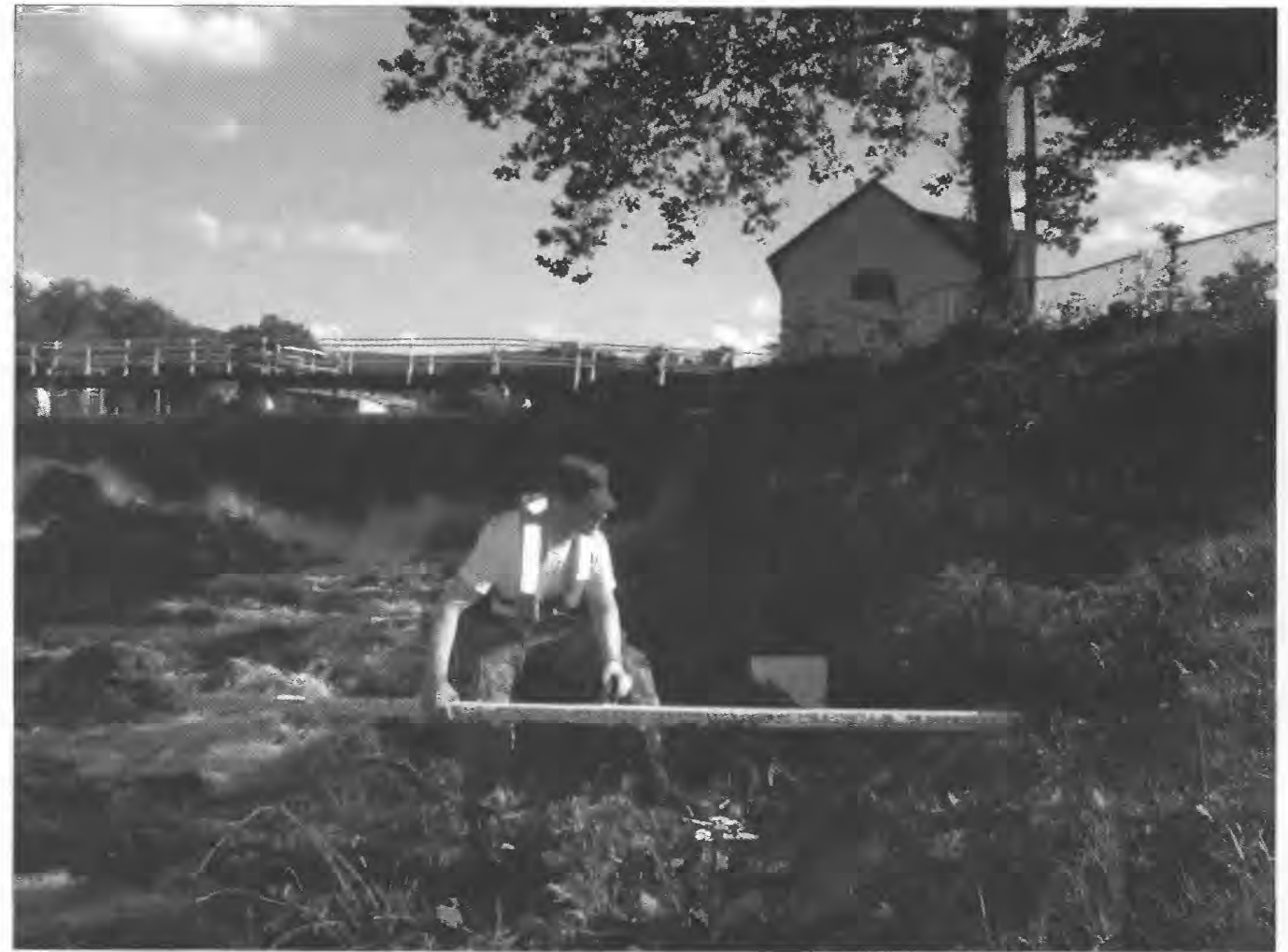

High-water mark W9.3 is a fair debris line on left bank, halfway between dam and upstream side of bridge, at elevation 525.2 feet above sea level.

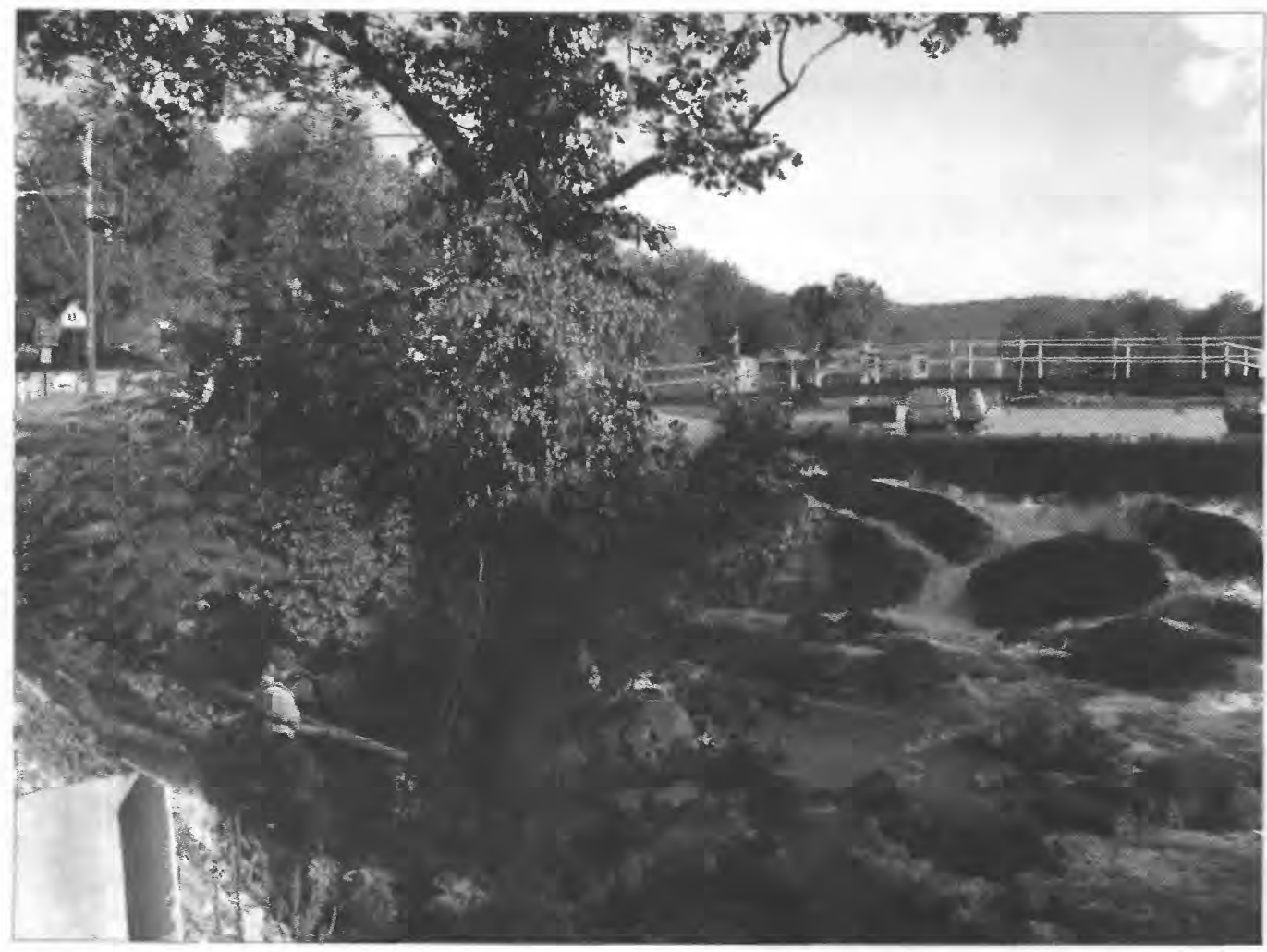

High-water mark W9.4 is a fair debris line on right bank, between dam and upstream side of bridge, at elevation 524.9 feet above sea level. 
Site W9 (01367700) Wallkill River at outlet at Franklin Pond at Franklin, N.J.

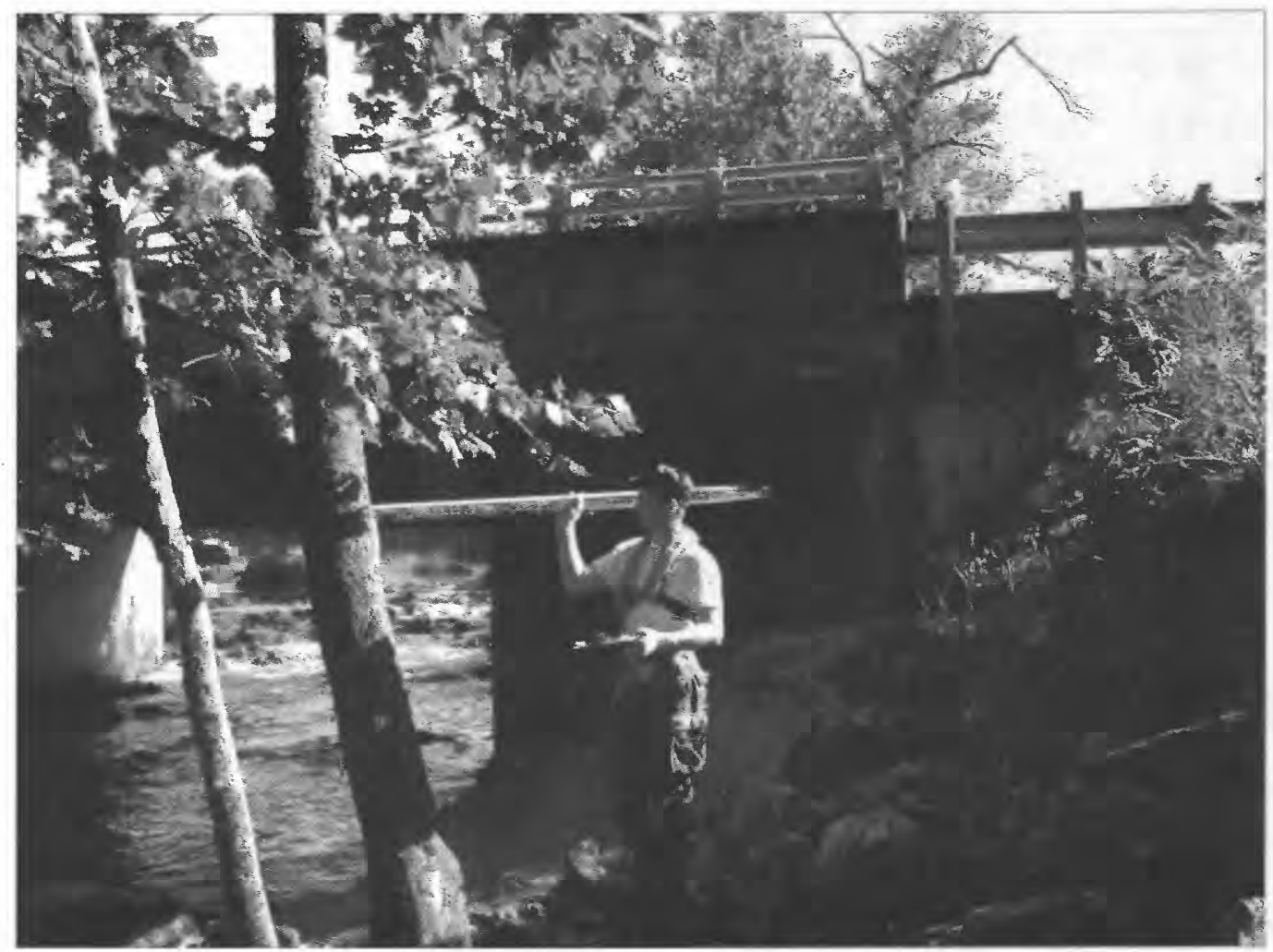

High-water mark W9.5 is a poor seed line on 12-inch-diameter tree, 15 feet downstream from bridge on left bank, 6.5 feet above ground, at elevation 523.3 feet above sea level.

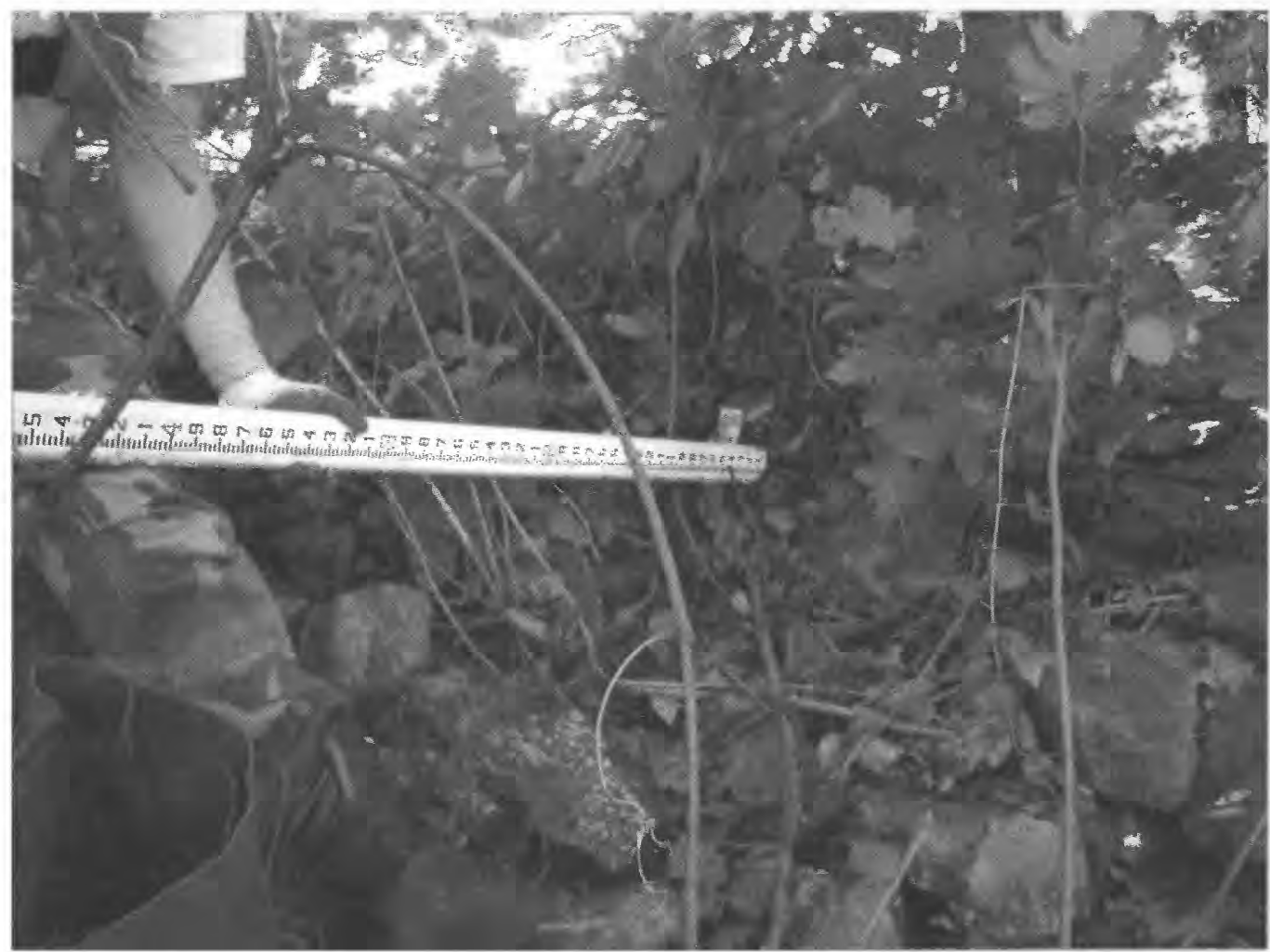

High-water mark W9.6 is a fair debris line on earthen bank, 30 feet downstream from bridge on right bank, at elevation 523.5 feet above sea level. 


\section{SITE DESCRIPTION}

Site W10: Wallkill River at Wildcat Road at Frankiln, N.J.

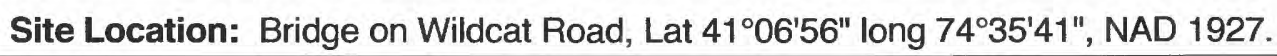

Franklin Borough, Sussex County, New Jersey, Community 340454

Franklin USGS 7.5' Topographic Quadrangle

High-Water Marks: Four high-water marks were flagged: 3 good seed lines, and 1 fair mud line.

Photos of each high-water mark are attached. See field notes for GPS readings at each mark, filed at USGS office in West Trenton, N.J.

High-water marks flagged and photos taken by T.J. Reed and R.W. Edwards on September 18, 2000. Surveying was completed on October 25, 2000.

High-water-mark elevations were surveyed from U.S. Coast and Geodetic Survey benchmark (Franklin 3) located at the site W9.

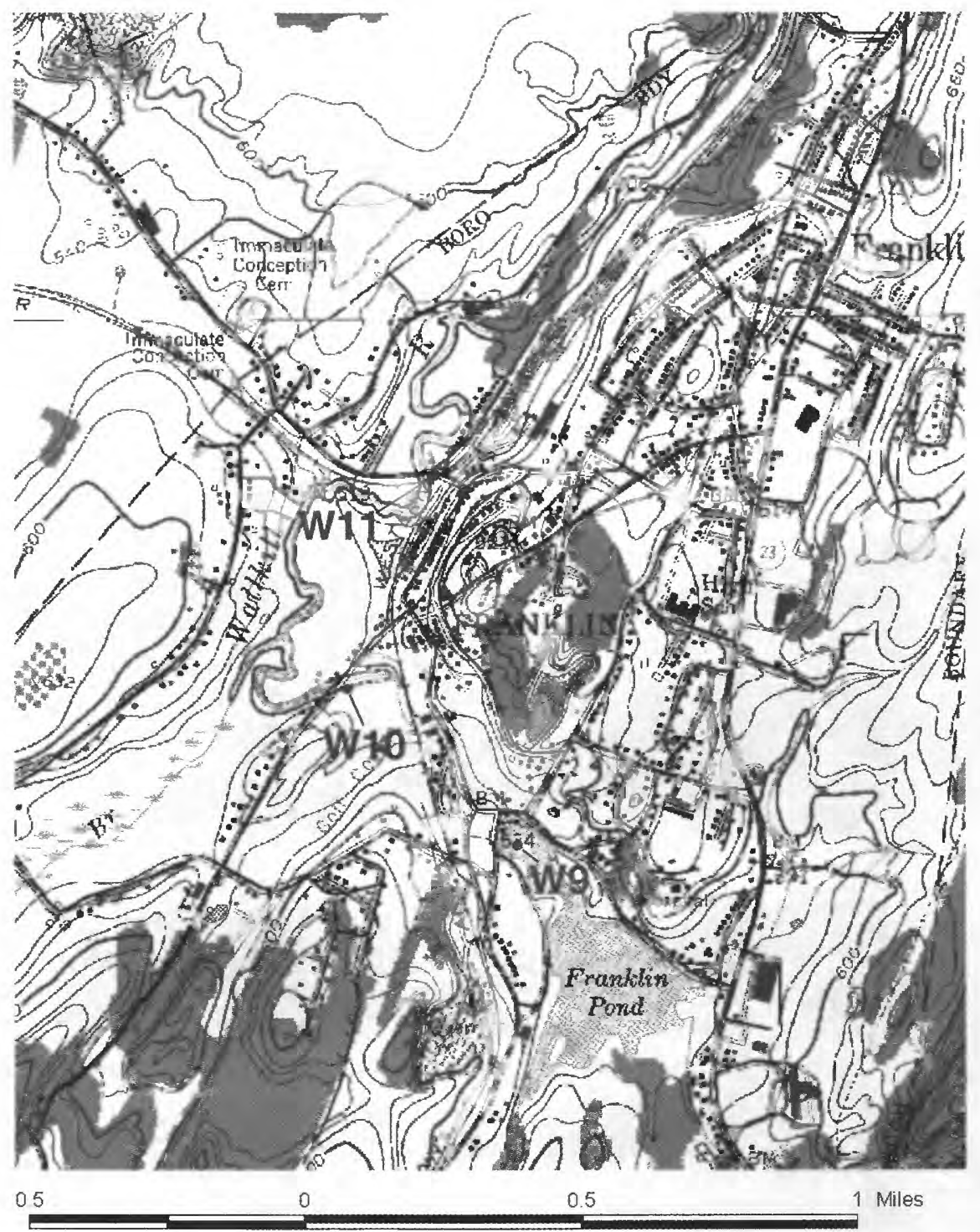

Franklin/Hamburg quad map showing location of site W10, Wallkill River at outlet of Franklin Pond at Franklin, N.J. 
Site W10 Wallkill River at Wildcat Road at Franklin, N.J.

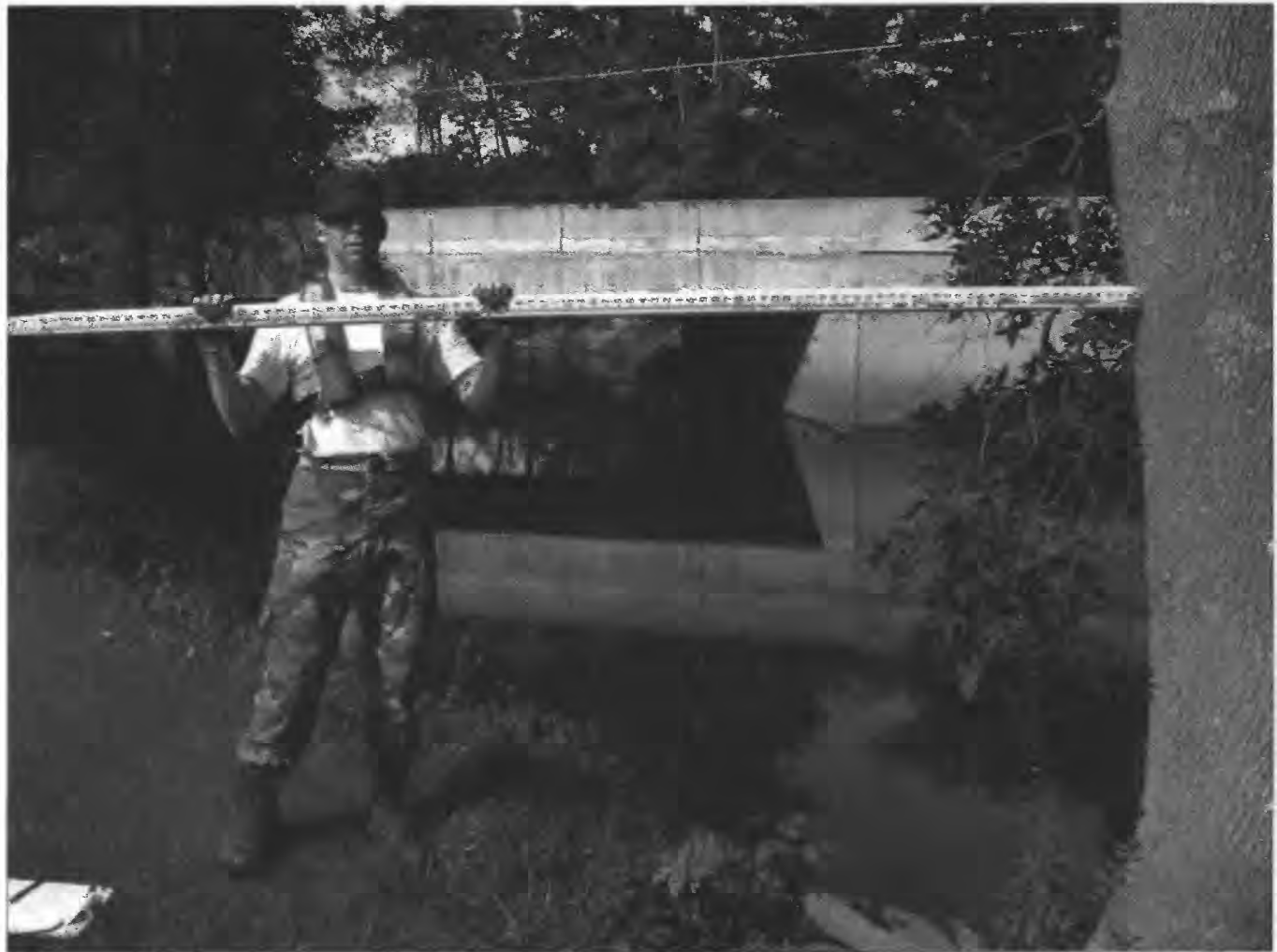

High-water mark W10.1 is a good mud line on 18-inch-diameter tree, 50 feet upstream from bridge on left bank, and 7.1 feet above ground on bank side of tree, at elevation 514.1 feet above sea level.

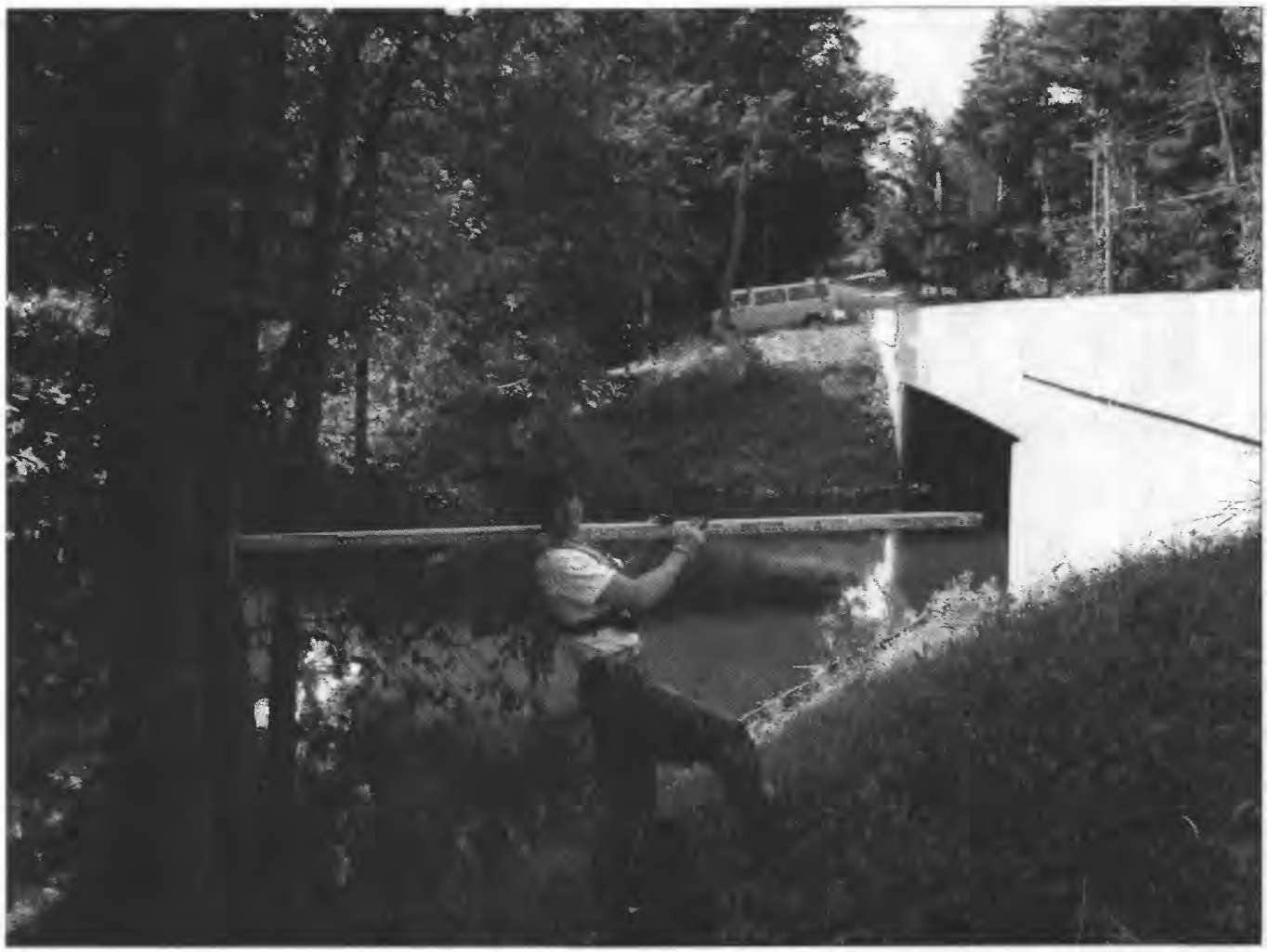

High-water mark W10.2 is a good mud line on 8-inch-diameter tree, 18 feet upstream from bridge on right bank, and 6.1 feet above ground, at elevation 513.9 feet above sea level. 
Site W10 Wallkill River at Wildcat Road at Franklin, N.J.

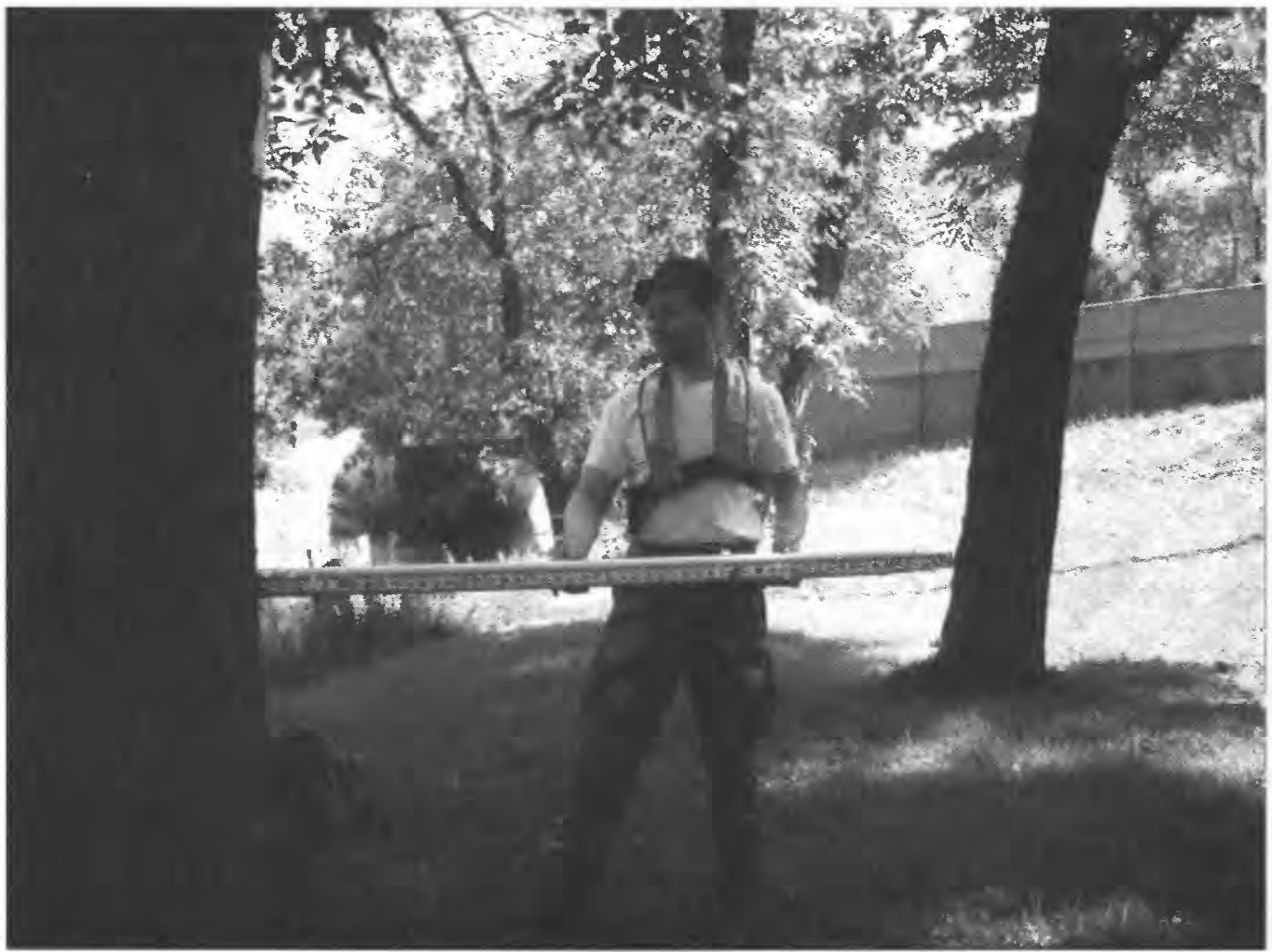

High-water mark W10.3 is a good mud line on 24-inch-diameter tree, 56 feet downstream from bridge on left bank and 3.2 feet above ground, at elevation 513.0 feet above sea level.

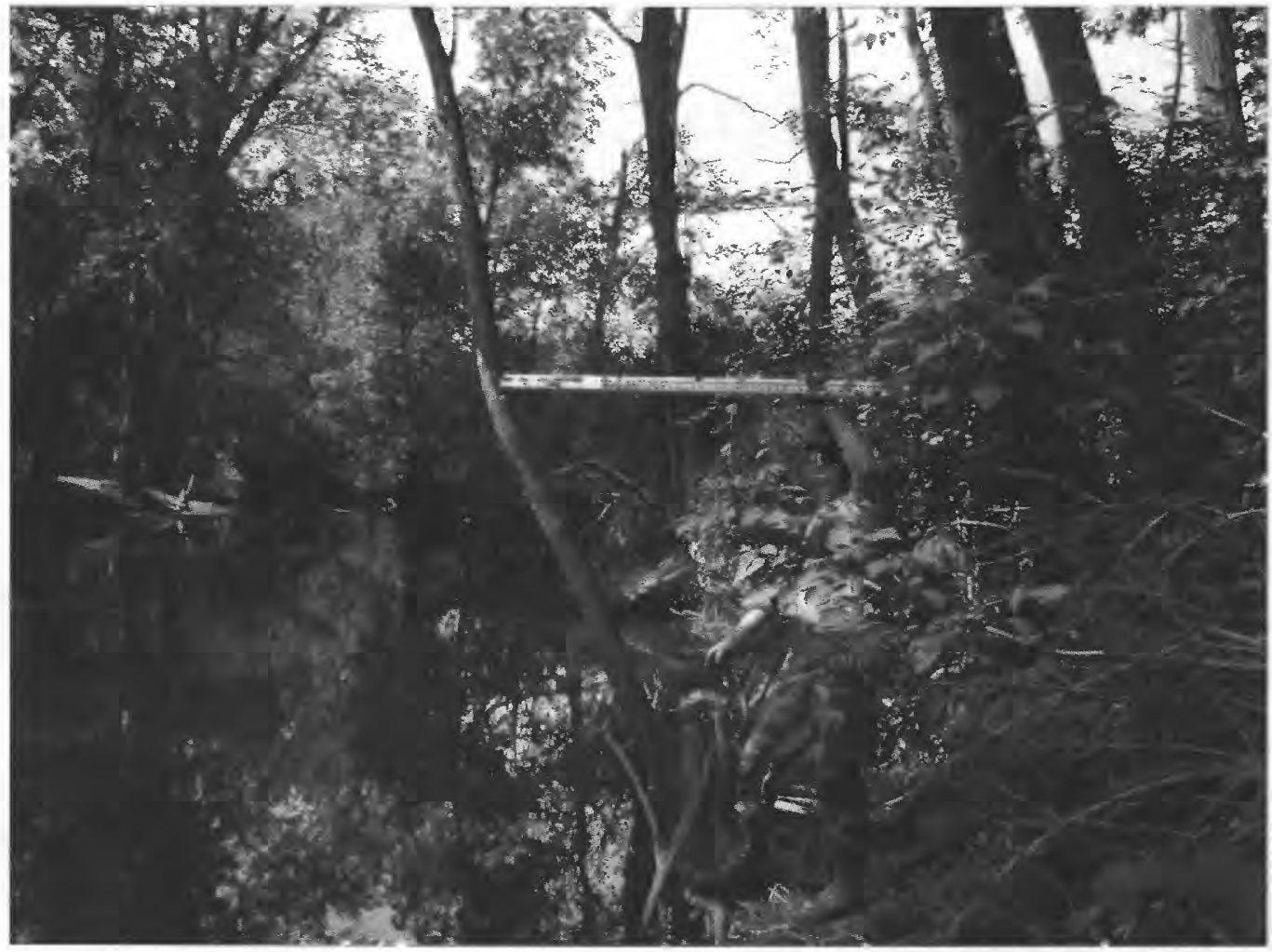

High-water mark W10.4 is a fair mud line on 5-inch-diameter tree, 50 feet downstream from bridge on right bank, and 7.0 feet above tree roots on bank, at elevation 512.6 feet above sea level. 


\section{SITE DESCRIPTION}

Site W11: Wallkill River at North Church Street at Frankiln, N.J.

Site Location: Bridge on North Church Street, Lat $41^{\circ} 07^{\prime} 15^{\prime \prime}$ long $74^{\circ} 35^{\prime} 31^{\prime \prime}$, NAD 1927.

Franklin Borough, Sussex County, New Jersey, Community 340449

Franklin USGS 7.5' Topographic Quadrangle

High-Water Marks: Four high-water marks were flagged: 4 good mud lines.

Photos of each high-water mark are attached. See field notes for GPS readings at each mark, filed at USGS office in West Trenton, N.J.

High-water marks flagged and photos taken by T.J. Reed and R.W. Edwards on September 18, 2000. Surveying was completed on October 24, 2000.

High-water-mark elevations were surveyed from U.S. Coast and Geodetic Survey benchmark (Franklin 3) located at the site W9.

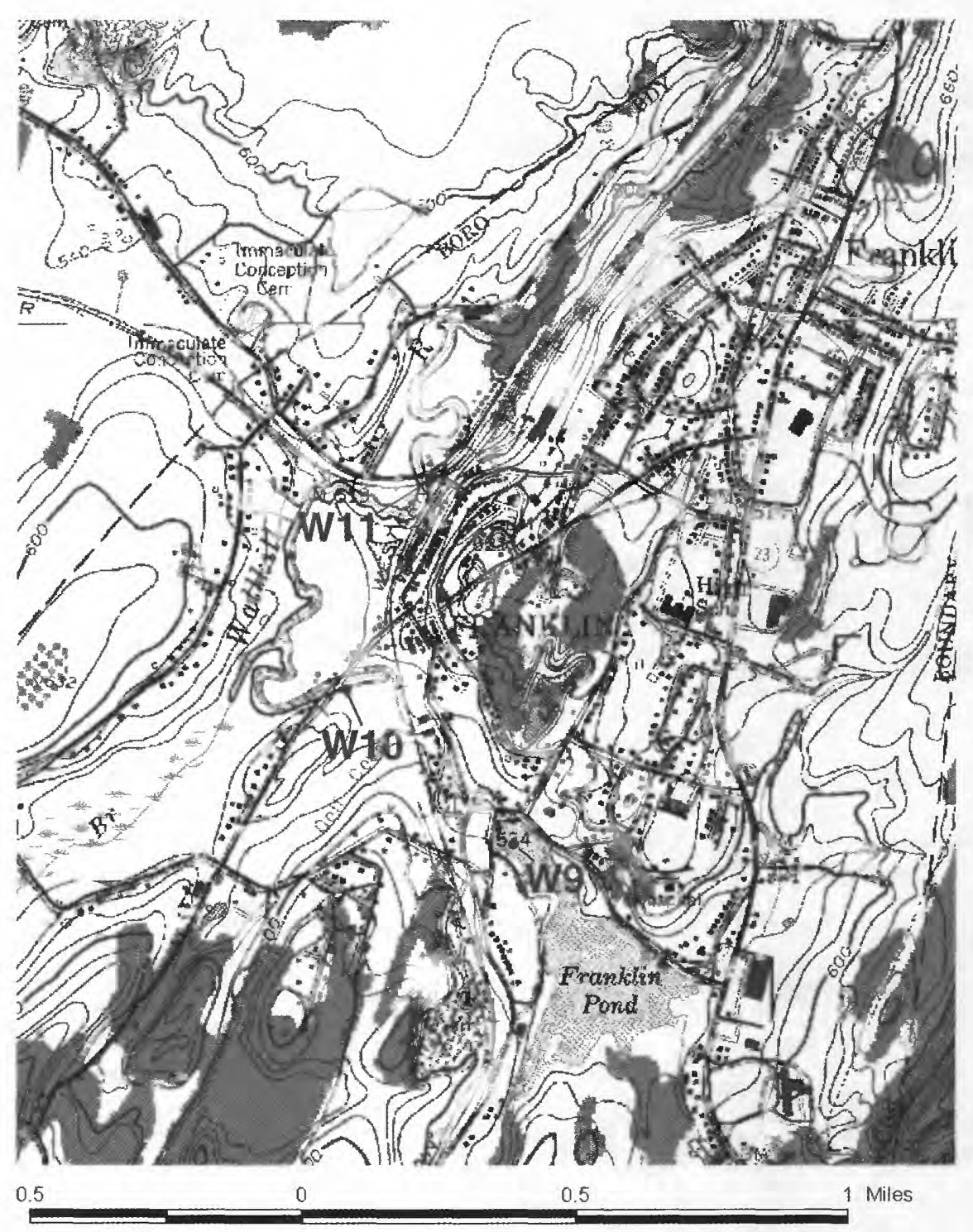

Franklin/Hamburg quad map showing location of site W11, Wallkill River at outlet of North Church Street at Franklin, N.J. 
Site W11 Wallkill River at North Church Street at Franklin, N.J.

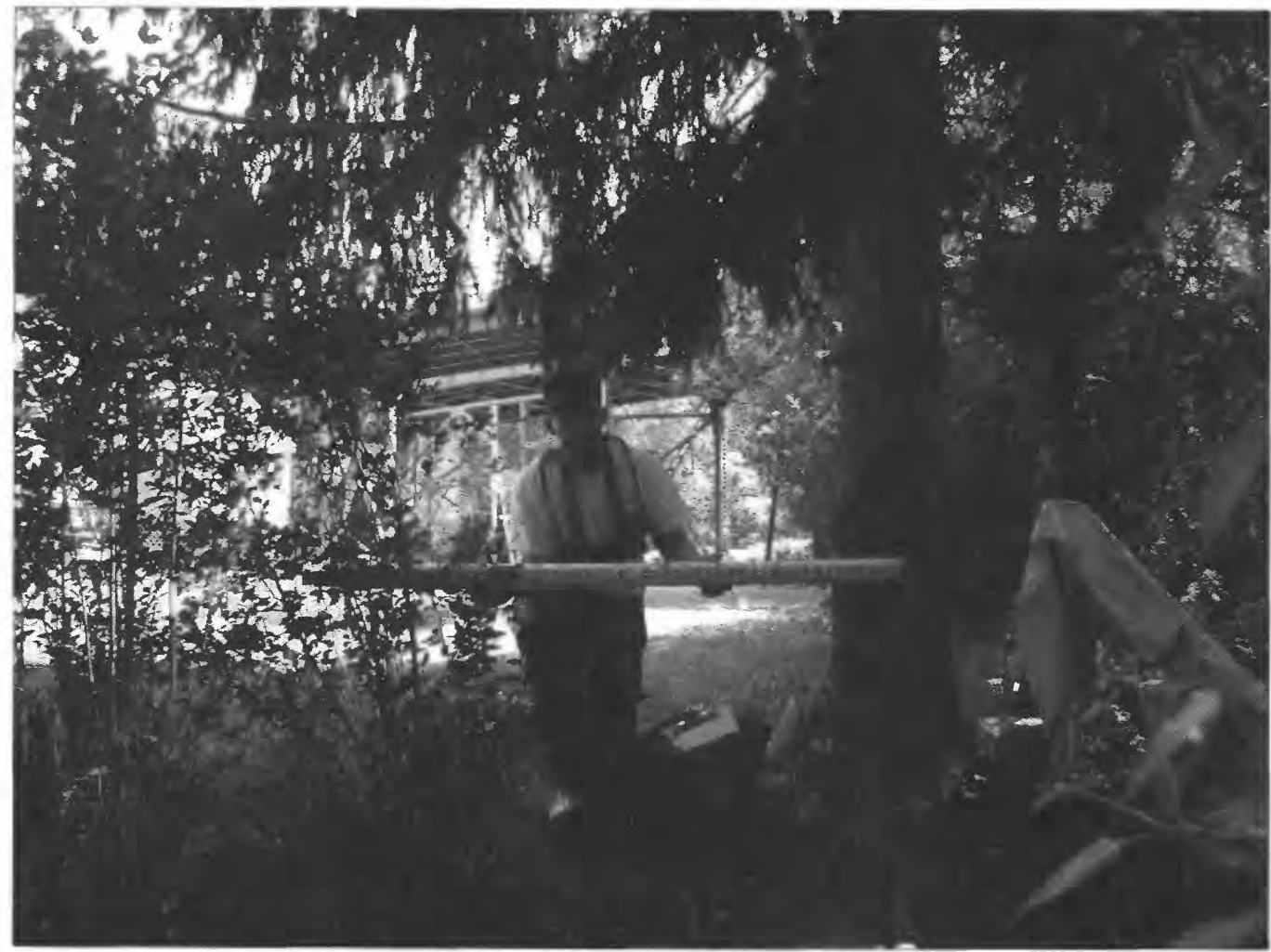

High-water mark W11.1 is a good mud line on 12-inch-diameter spruce tree, 120 feet downstream from bridge on right bank, 17 feet from right side of river and 2.2 feet above ground, at elevation 509.5 feet above sea level.

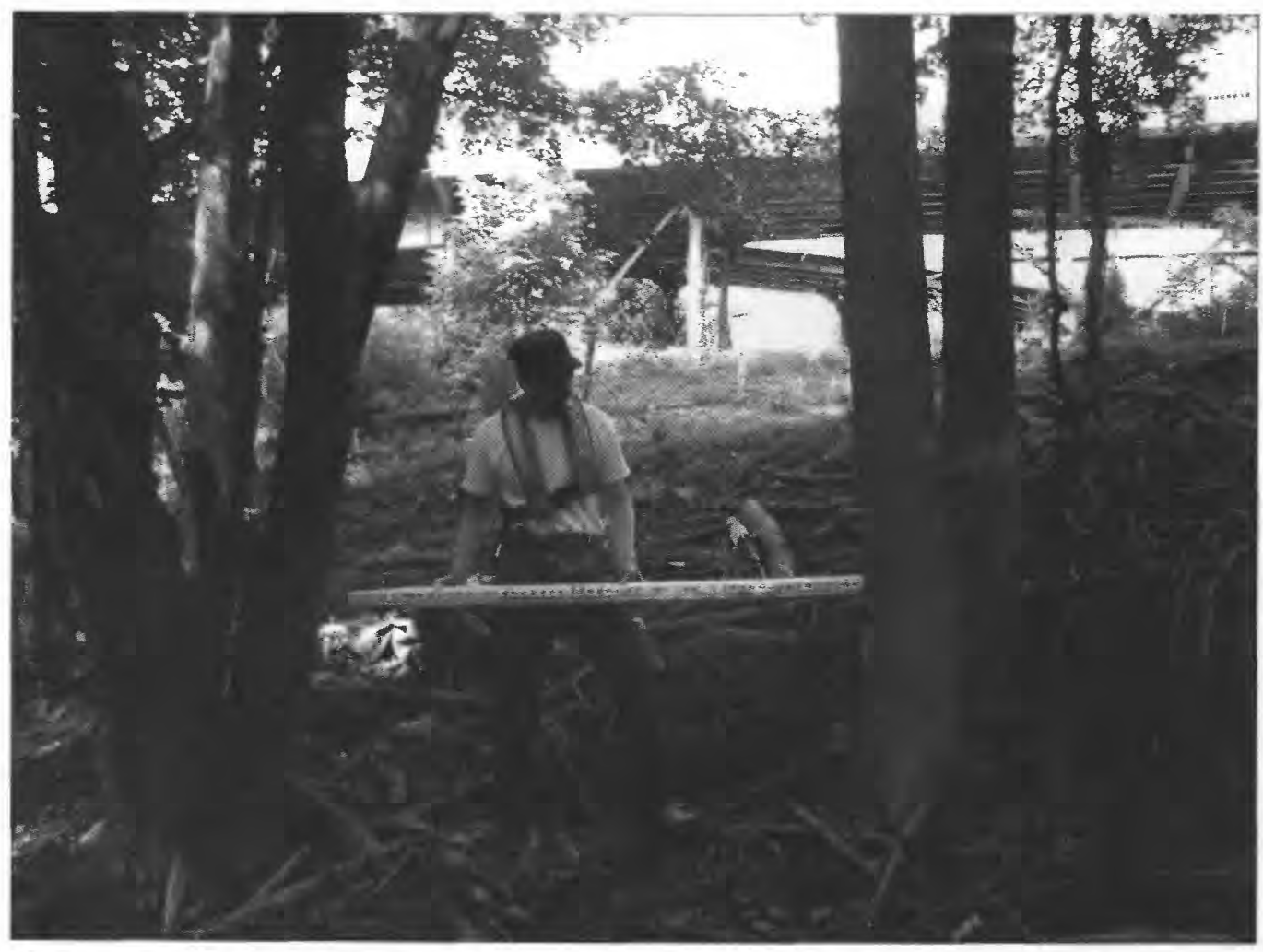

High-water mark W11.2 is a good mud line on 12-inch-diameter tree, 100 feet upstream from bridge on right bank, and 2.4 feet above ground, at elevation 510.9 feet above sea level. (This mark may be affected by backwater from debris.) 
Site W11 Wallkill River at North Church Street at Franklin, N.J.

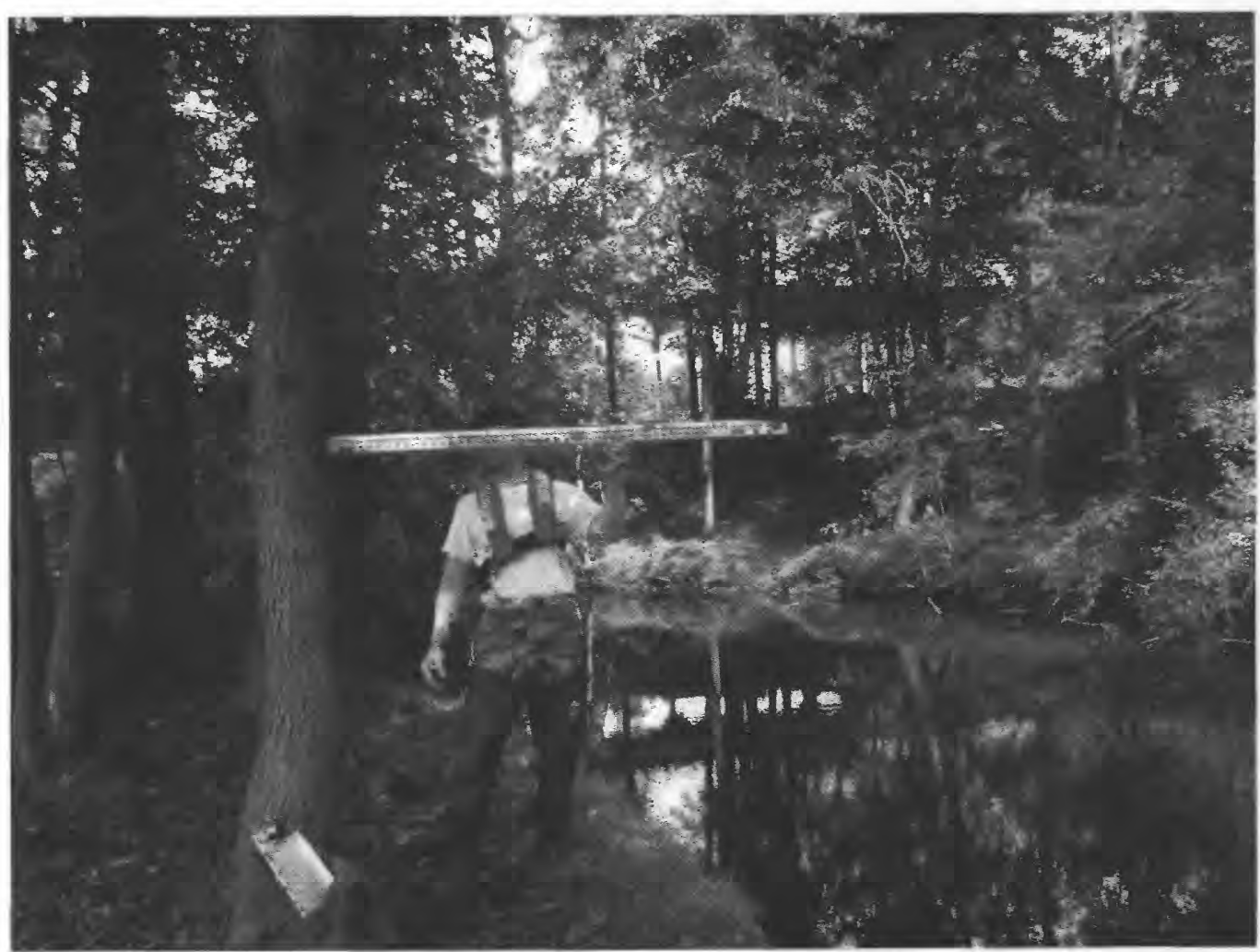

High-water mark W11.3 is a good mud line on 8-inch-diameter tree, 150 feet upstream from bridge on left bank, 5.0 feet from left bank and 5.1 feet above ground, at elevation 509.9 feet above sea level.

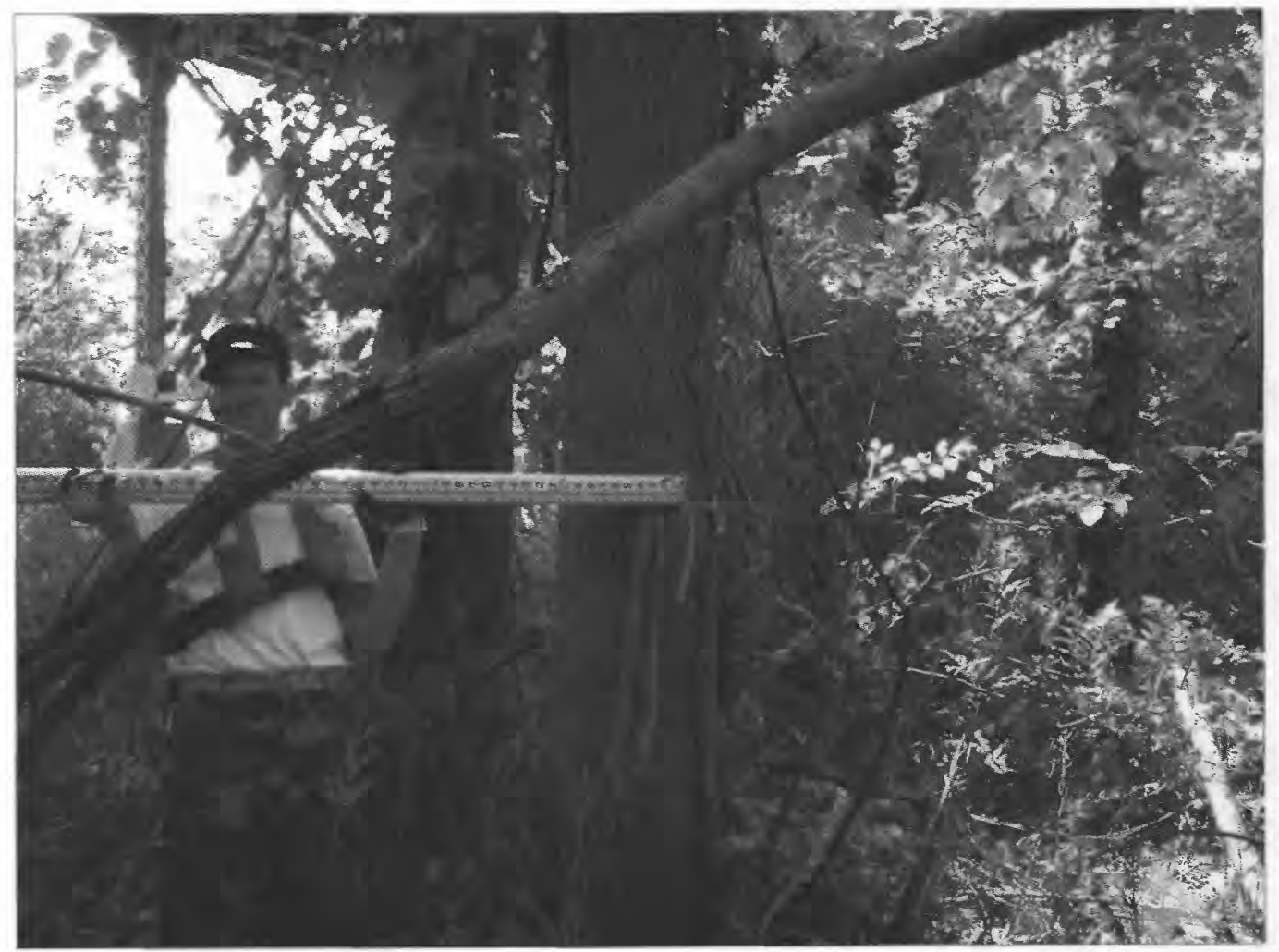

High-water mark W11.4 is a good mud line on 15-inch-diameter tree, 40 feet downstream from bridge on left bank, and 5.0 feet above ground, at elevation 509.5 feet above sea level. 


\section{SITE DESCRIPTION}

Site W12 (USGS water-quality site 01367715): Wallkill River at Scott Road at Frankiln, N.J.

Site Location: Bridge on Scott Road, Lat $41^{\circ} 08^{\prime} 00^{\prime \prime}$ long $74^{\circ} 34^{\prime} 43^{\prime \prime}$, NAD 1927. Drainage area: 40.6 square miles

Franklin Borough, Sussex County, New Jersey, Community 340449

Hamburg USGS 7.5' Topographic Quadrangle

High-Water Marks: Four high-water marks were flagged: 2 fair debris lines, 1 fair mud line, and 1 poor debris line.

Photos of each high-water mark are attached. See field notes for GPS readings at each mark, filed at USGS office in West Trenton, N.J.

High-water marks flagged and photos taken by T.J. Reed and R.W. Edwards on September 18, 2000. Surveying was completed on October 24, 2000.

High-water-mark elevations were surveyed from benchmark RV68.

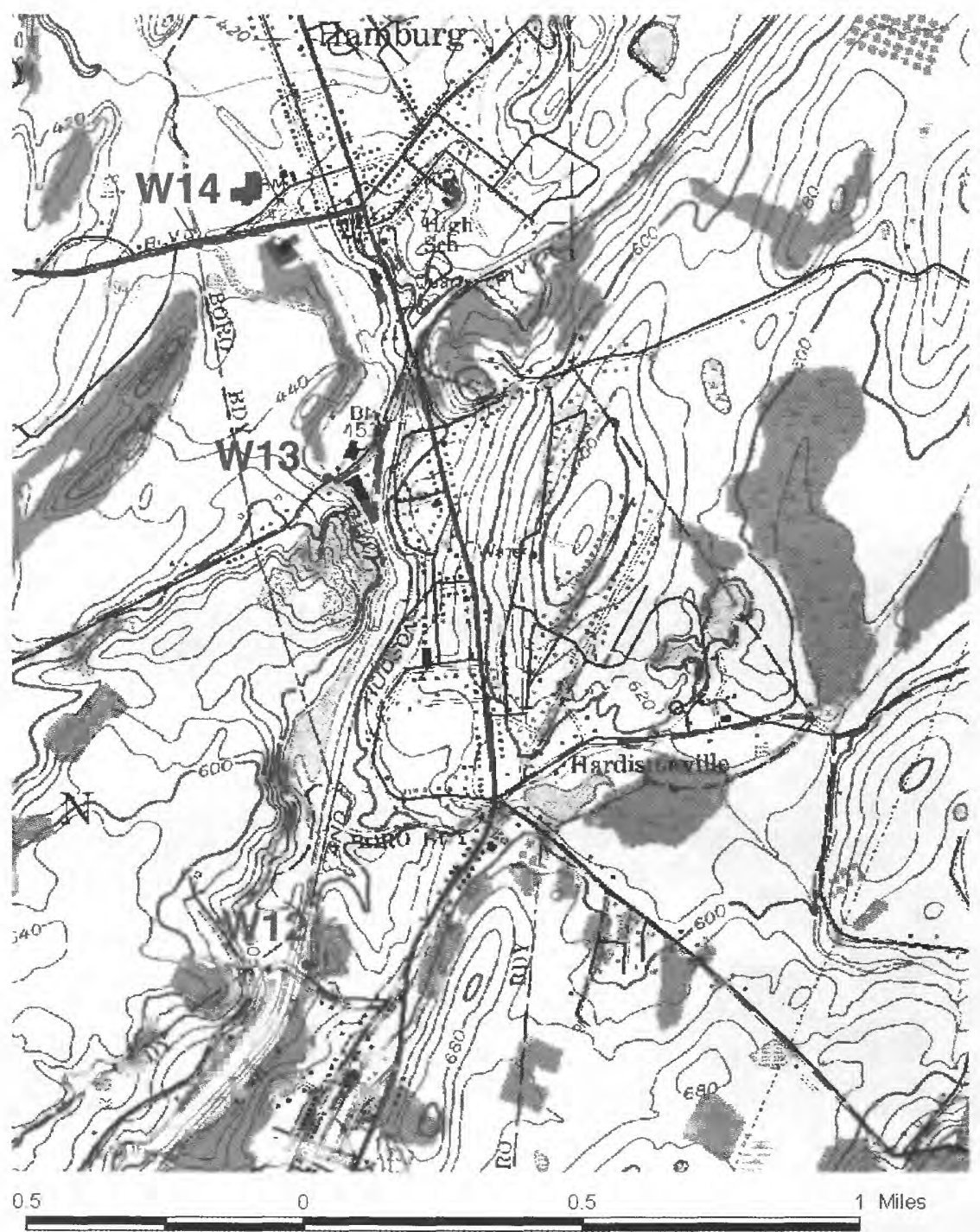

Hamburg quad map showing location of site W12, Wallkill River at outlet of Scott Road at Franklin, N.J. 


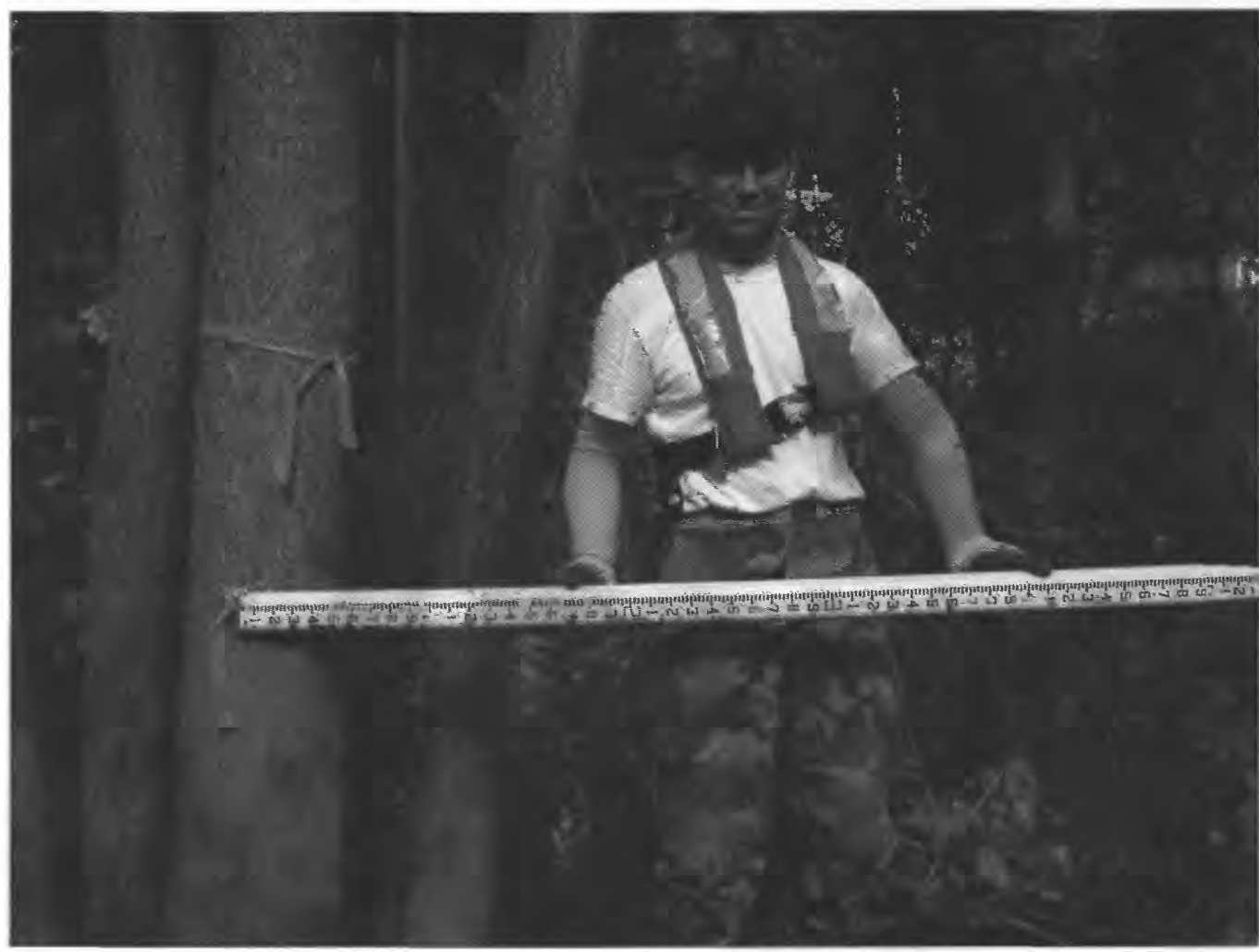

High-water mark W12.1 is a fair mud line on 12-inch-diameter tree, 70 feet upstream from bridge on left bank, 30 feet from left side of river, and 3.2 feet above ground, at elevation 494.1 feet above sea level.

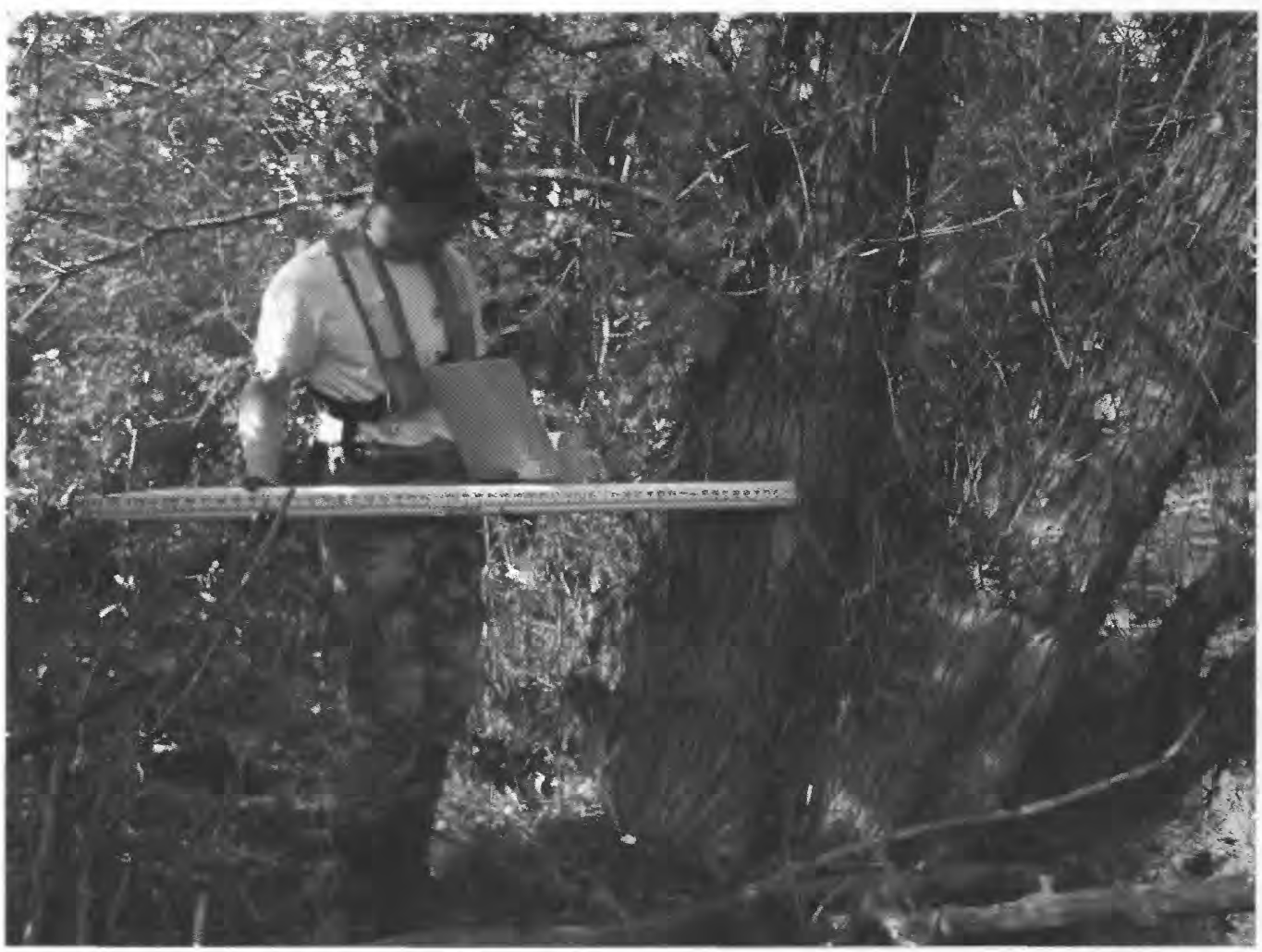

High-water mark W12.2 is a fair debris line on 24-inch-diameter tree, 34 feet downstream from bridge on left bank, and 3.1 feet above ground, at elevation 491.5 feet above sea level. 
Site W12 (01367715) Wallkill River at Scott Road at Franklin, N.J.

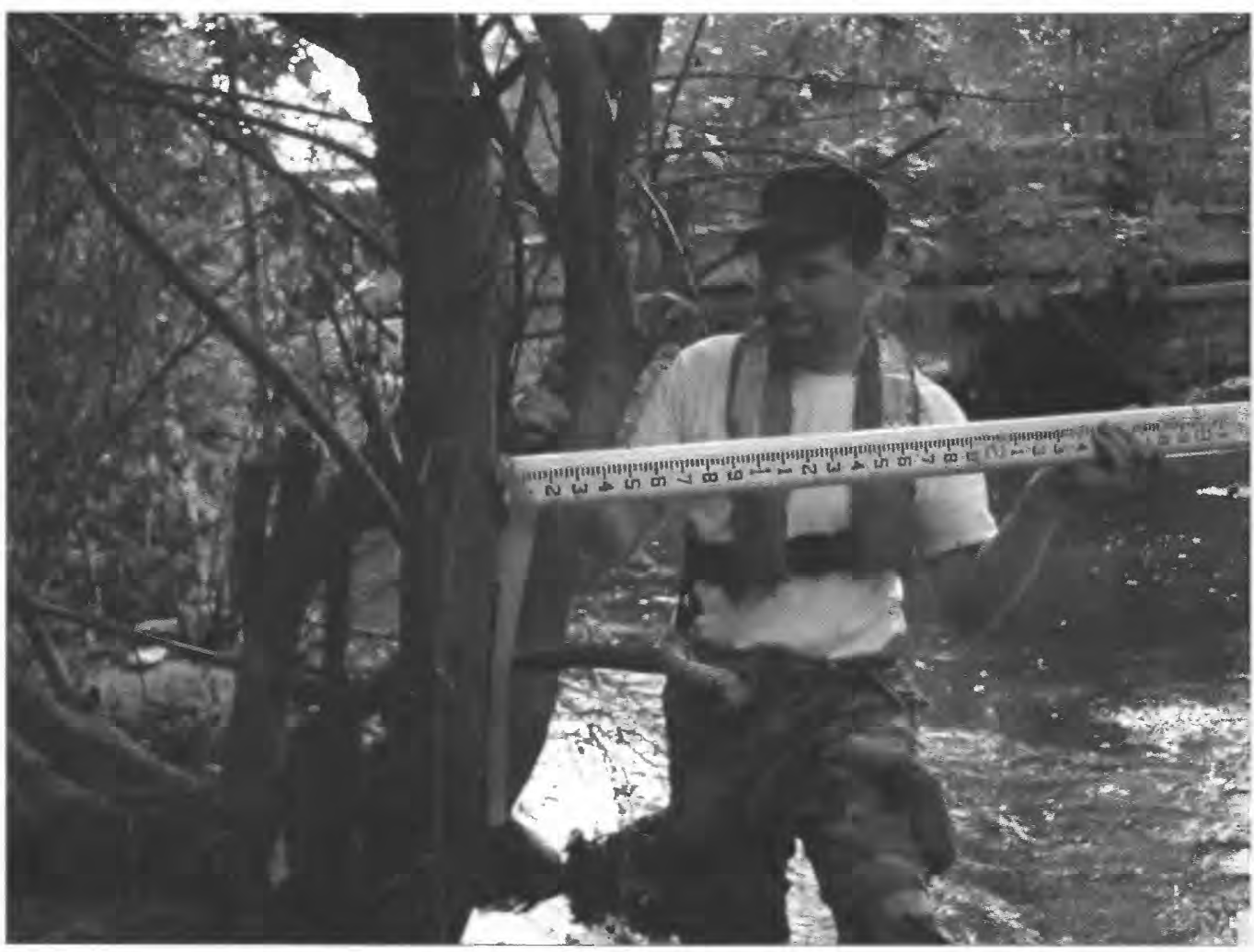

High-water mark W12.3 is a fair mud line on 5-inch-diameter tree at edge of water, 50 feet downstream from bridge on right bank, and 3.5 feet above ground, at elevation 491.4 feet above sea level.

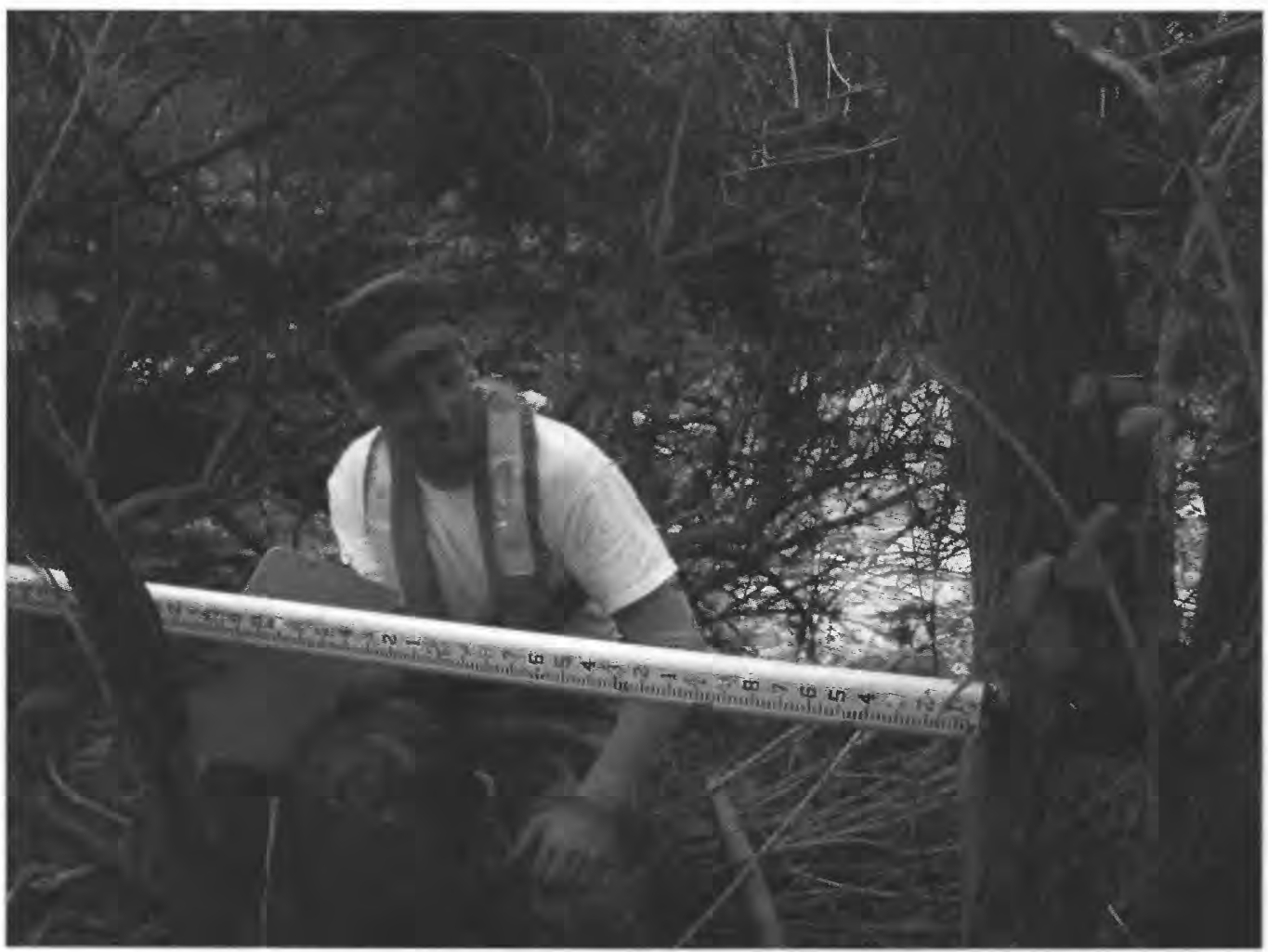

High-water mark W12.4 is a poor debris line on 24-inch-diameter tree, 70 feet upstream from bridge on right bank, and 2.3 feet above ground, at elevation 493.2 feet above sea level. 


\section{SITE DESCRIPTION}

Site W13: Wallkill River at Wheatsworth Road at Hamburg, N.J.

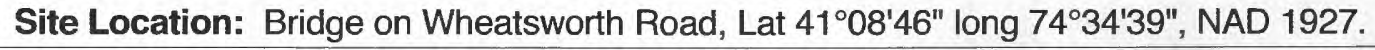

Hamburg Borough, Sussex County, New Jersey, Community 340450

Hamburg USGS 7.5' Topographic Quadrangle

High-Water Marks: 15 high-water marks were flagged: used marks 6 and 7 downstream side of bridge. These marks are good and fair debris lines.

Photos of some high-water marks: however, no photos of high-water marks 6 and 7 were taken. No GPS readings were taken at the marks.

High-water marks flagged and photos taken by J.F. Dudek and G.M. Bosonetto on September 13, 2000. Surveying was completed on September 13, 2000.

J.F. Dudek and G.M.Bosonetto surveyed high-water marks from benchmark U13 to high-water marks $6,7,13,14$, and 15 on September 13, 2000.

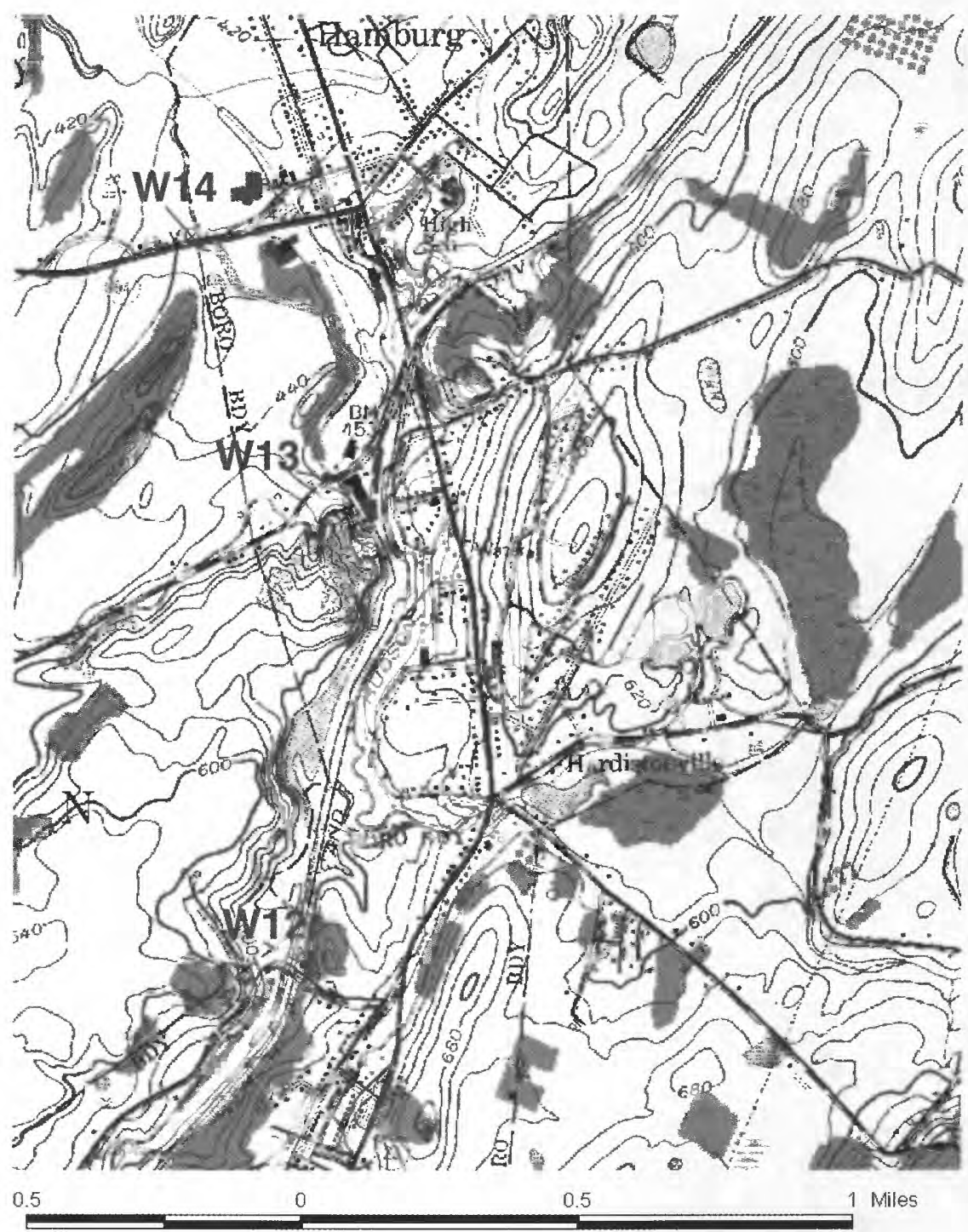

Hamburg quad map showing location of site W13, Wallkill River at Wheatsworth Road at Franklin, N.J. 
No photos were taken of the high-water marks surveyed. A description of each mark surveyed by J.F. Dudek and G.M. Bosonetto on September 13, 2000, is given below.

High-water mark W13.6 is a fair debris line, 15 feet downstream from bridge, on the left bank, at elevation $\mathbf{4 3 7 . 1}$ feet above sea level.

High-water mark W13.7 is a good debris line, 38 feet downstream from bridge, on the left bank, at elevation $\mathbf{4 3 5 . 8}$ feet above sea level.

High-water mark W13.13 is a good debris line/wash line, 10 feet upstream from bridge, on the left bank, at elevation $\mathbf{4 3 8 . 7}$ feet above sea level.

High-water mark W13.14 is a good debris line on stone wall, 15 feet upstream from bridge, on the right bank, and 8.0 feet above ground, at elevation 439.4 feet above sea level.

High-water mark W13.15 is a good debris line, 80 feet downstream from bridge, on the right bank, at elevation $\mathbf{4 3 7 . 4}$ feet above sea level. 


\section{SITE DESCRIPTION}

Site W14 (USGS miscellaneous station 01367729): Wallkill River at Ames Boulevard at Hamburg, N.J.

Site Location: Bridge on Ames Boulevard, Lat $41^{\circ} 09^{\prime} 08^{\prime \prime}$ long $74^{\circ} 34^{\prime} 56^{\prime \prime}$, NAD 1927. Drainage area: 46.8 square miles

Hamburg Borough, Sussex County, New Jersey, Community 340450

Hamburg USGS 7.5' Topographic Quadrangle

High-Water Marks: Eight high-water marks were flagged: 5 good debris lines, 1 fair debris line, 1 fair wash line, and 1 poor debris line.

Photos of each high-water mark are attached. No GPS readings taken at the marks.

High-water marks flagged and photos taken by J.F. Dudek and G.M. Bosonetto on September 13, 2000. Surveying was completed on October 24, 2000.

High-water-mark elevations were surveyed from benchmark V13.

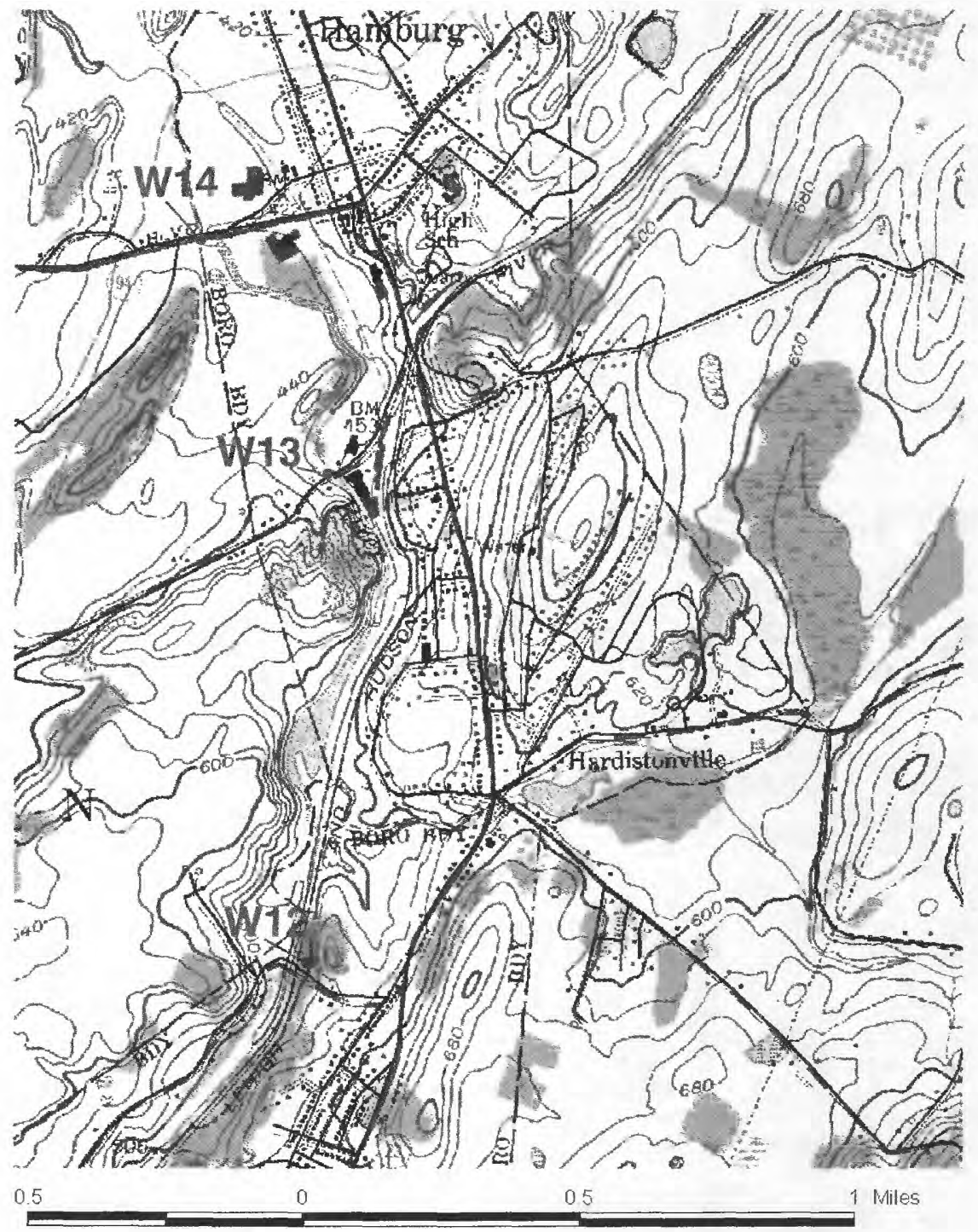

Hamburg quad map showing location of site W14 (01367721), Wallkill River at Ames Boulevard at Hamburg, N.J. 
Site W14 (01367721) Wallkill River at Ames Boulevard at Hamburg, N.J.

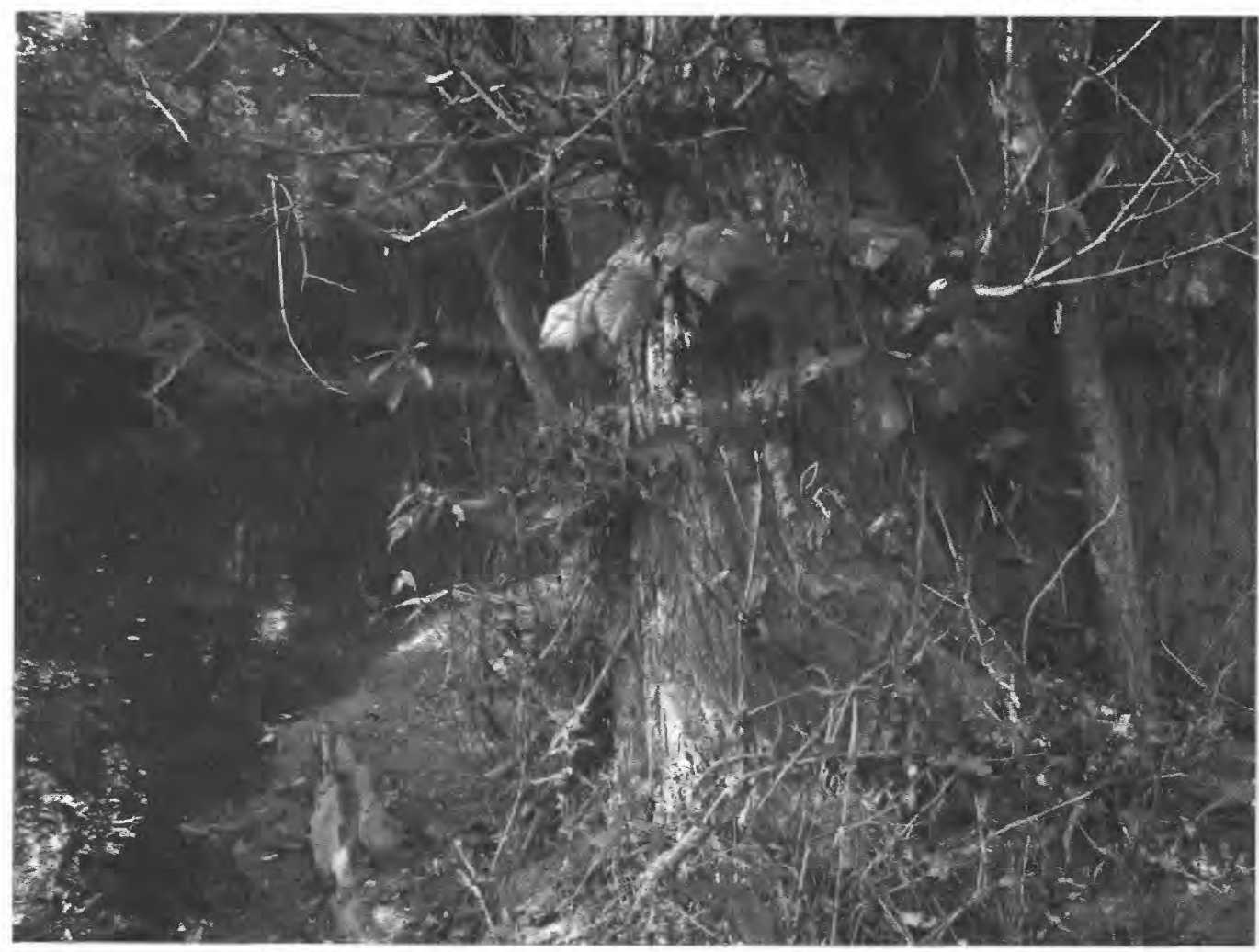

High-water mark W14.1 is a good debris line, 60 feet downstream from bridge on right bank, 3.6 feet above ground and 4.4 feet above current water surface, at elevation 406.4 feet above sea level.

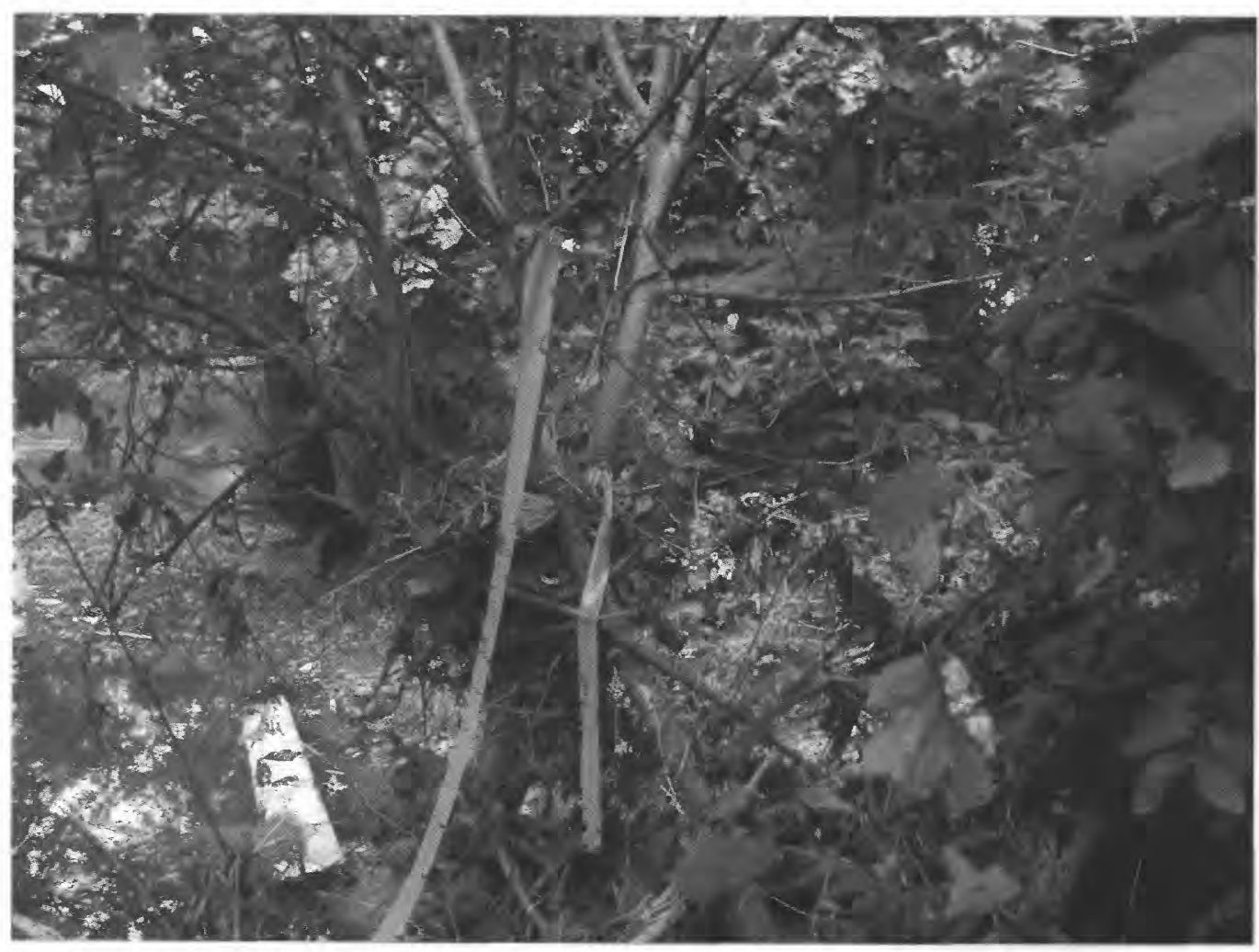

High-water mark W14.2 is a good debris line, 120 feet downstream from bridge on right bank, and 4.6 feet above ground, at elevation 406.6 feet above sea level. 
Site W14 (01367721) Wallkill River at Ames Boulevard at Hamburg, N.J.

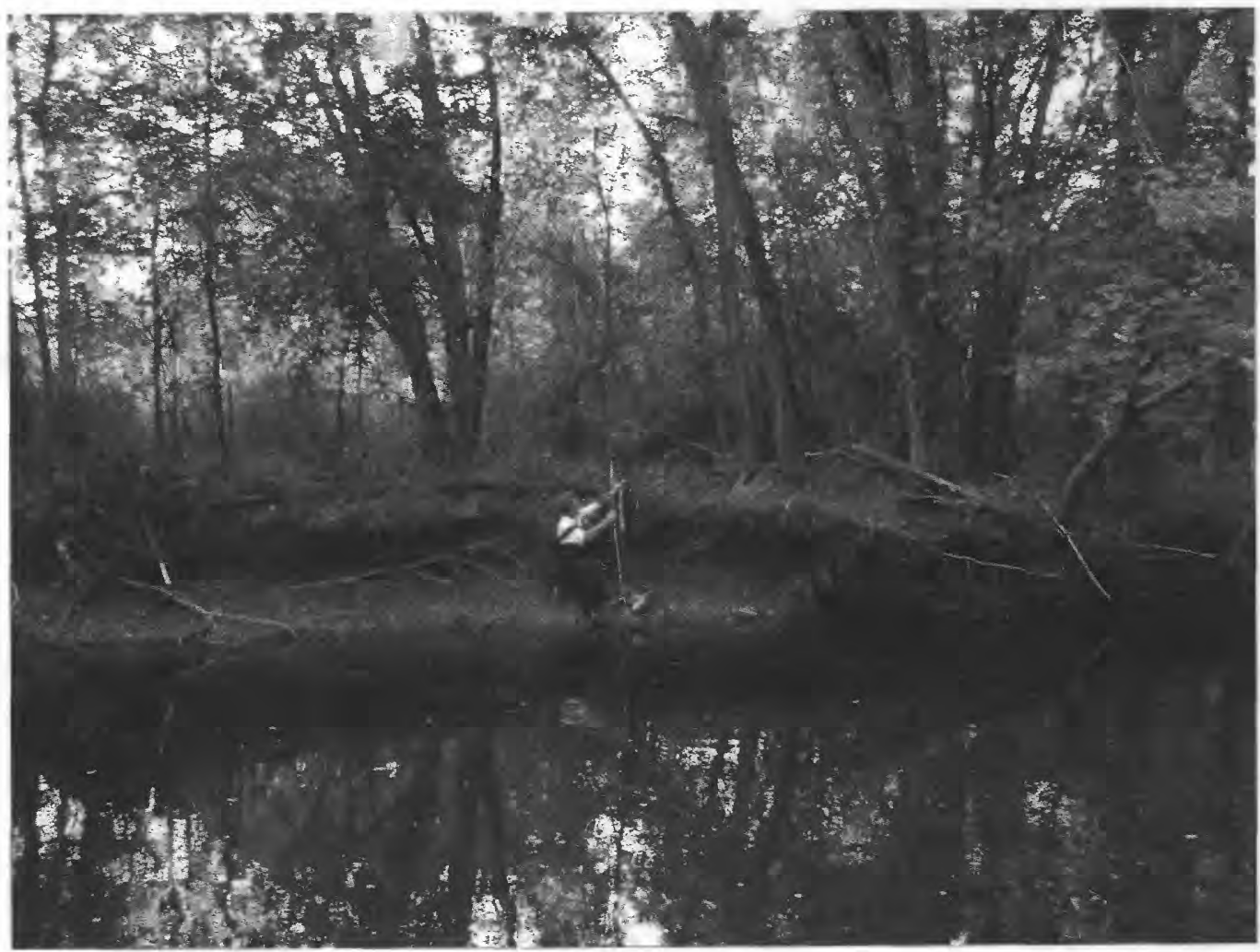

High-water mark W14.3 is a good debris line across from high-water mark 14.2, 120 feet downstream from bridge, on left bank, on 1 -foot-diameter tree, and 4.4 feet above current water surface, at elevation 406.3 feet above sea level.

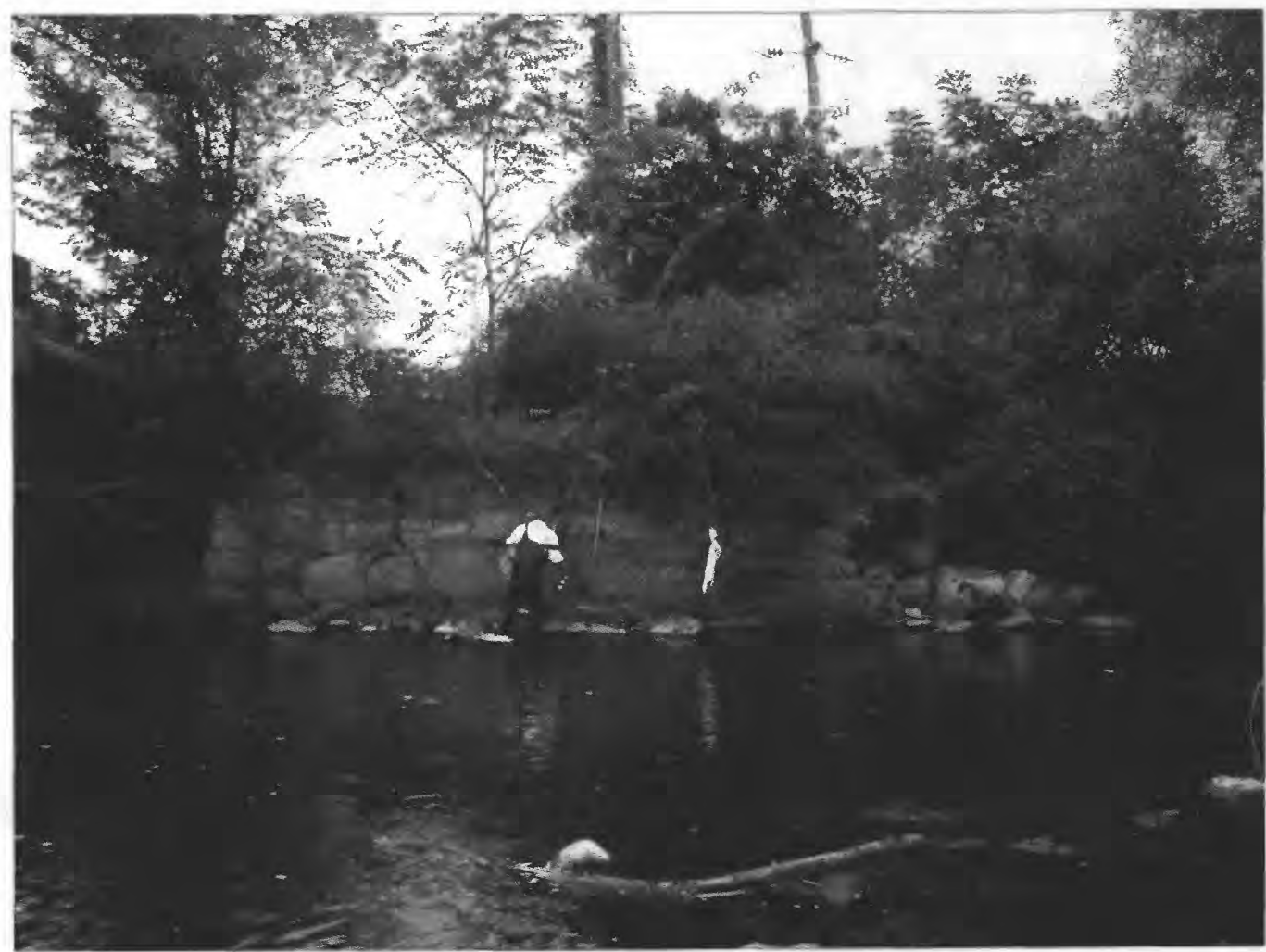

High-water mark W14.4 is a good debris line on wing wall, 25 feet downstream from bridge, on left bank, and 5.8 feet above water surface, at elevation 407.7 feet above sea level. 
Site W14 (01367721) Wallkill River at Ames Boulevard at Hamburg, N.J.

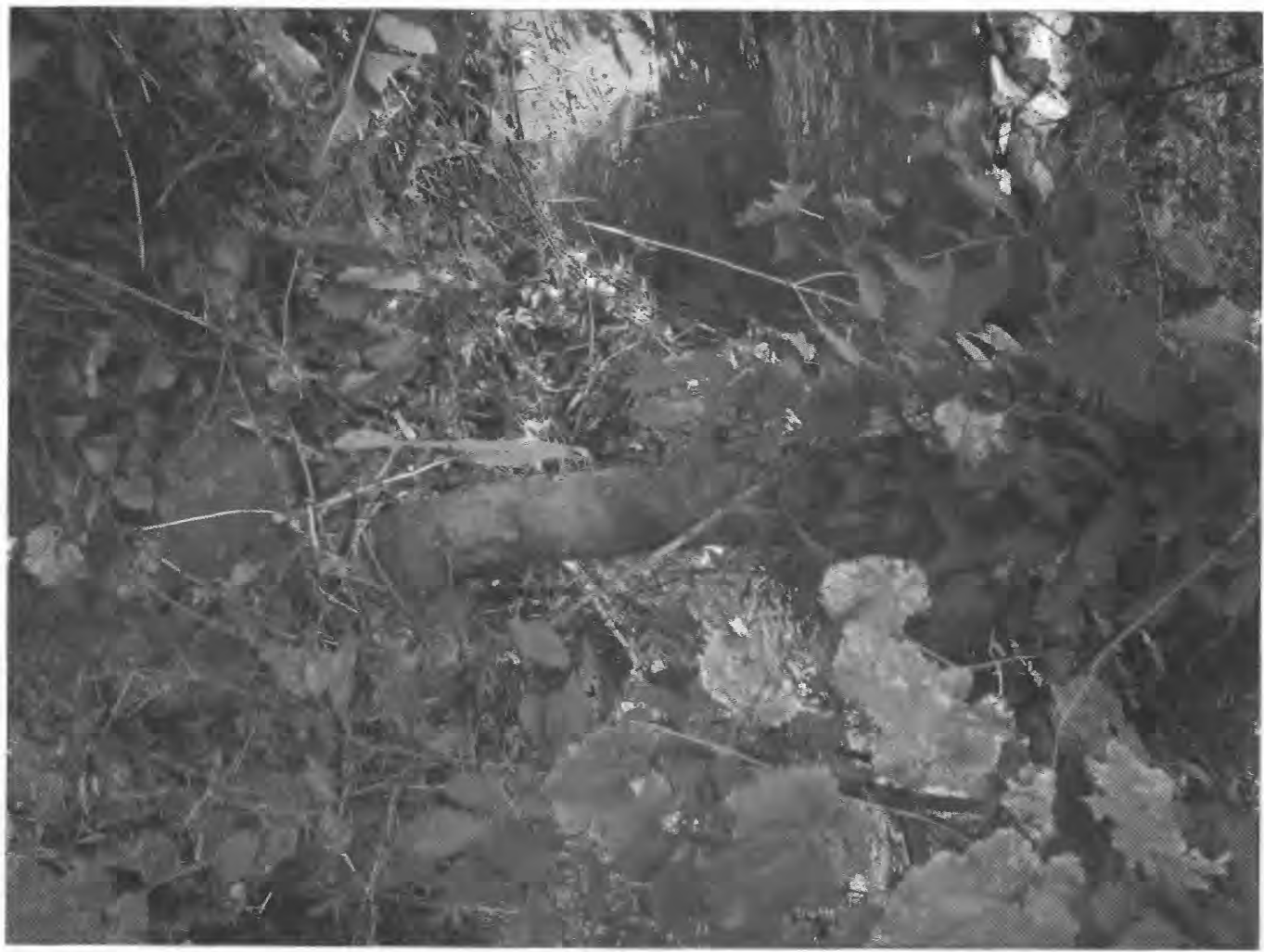

High-water mark W14.5 is a fair debris line on wing wall, 20 feet downstream from bridge, on left bank, and 1.9 feet above ground, at elevation 407.0 feet above sea level.

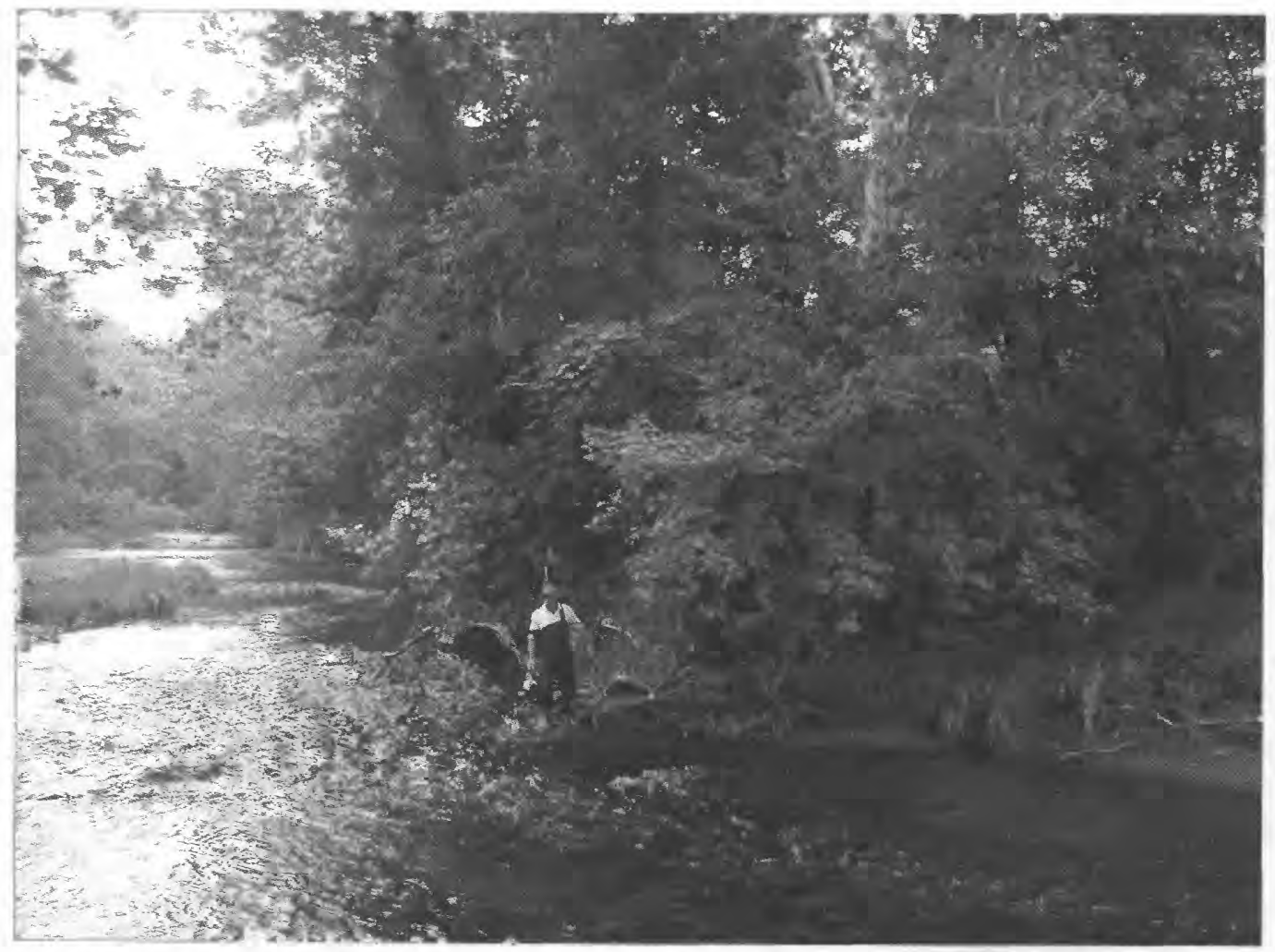

High-water mark W14.6 is a good debris line, 25 feet upstream from bridge, on left bank, at elevation 409.2 feet above sea level. 
Site W14 (01367721) Wallkill River at Ames Boulevard at Hamburg, N.J.

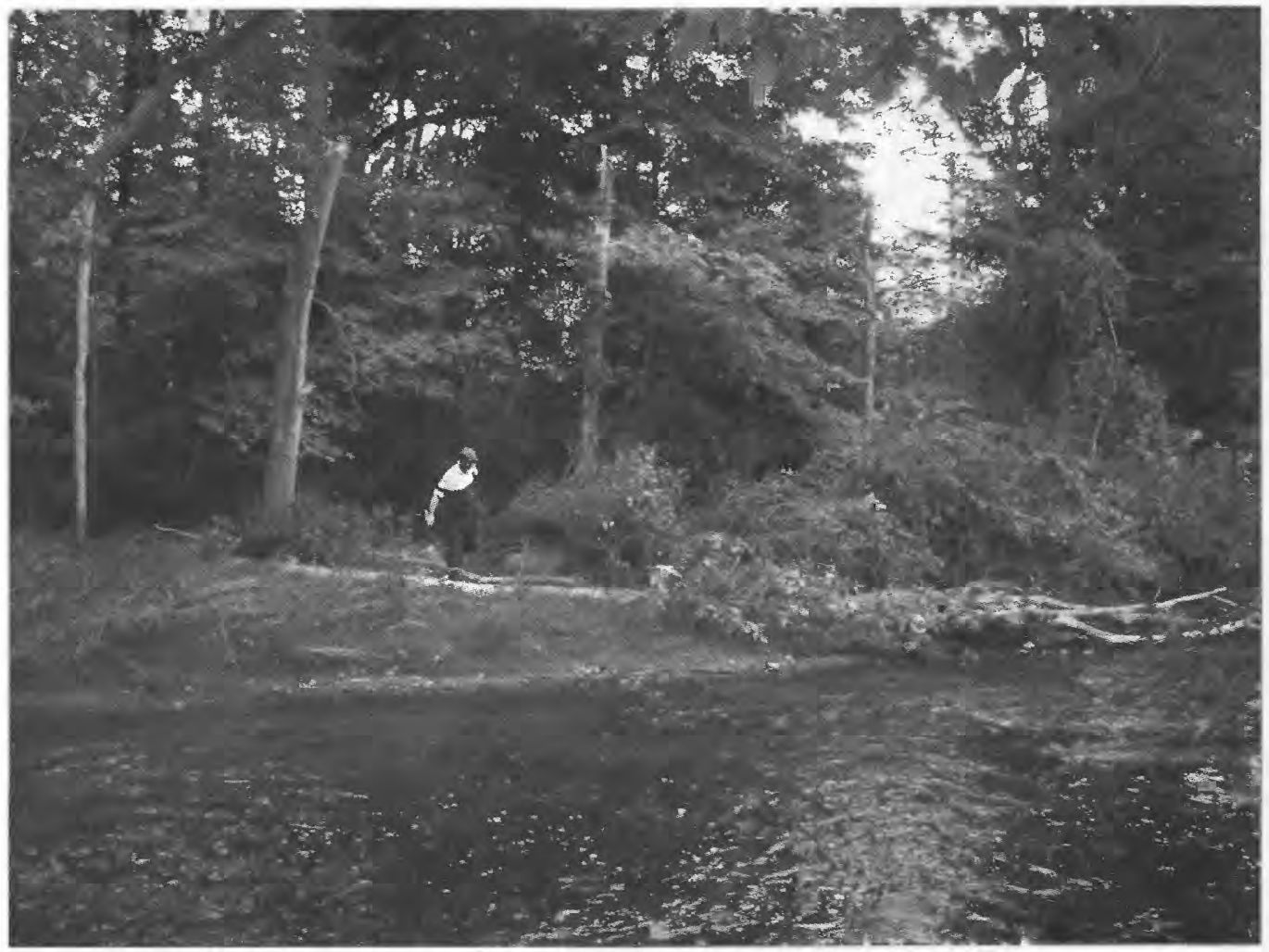

High-water mark W14.7 is a good debris line on dead tree, 15 feet upstream from bridge, on left bank, and 4.0 feet above ground, at elevation 408.8 feet above sea level.

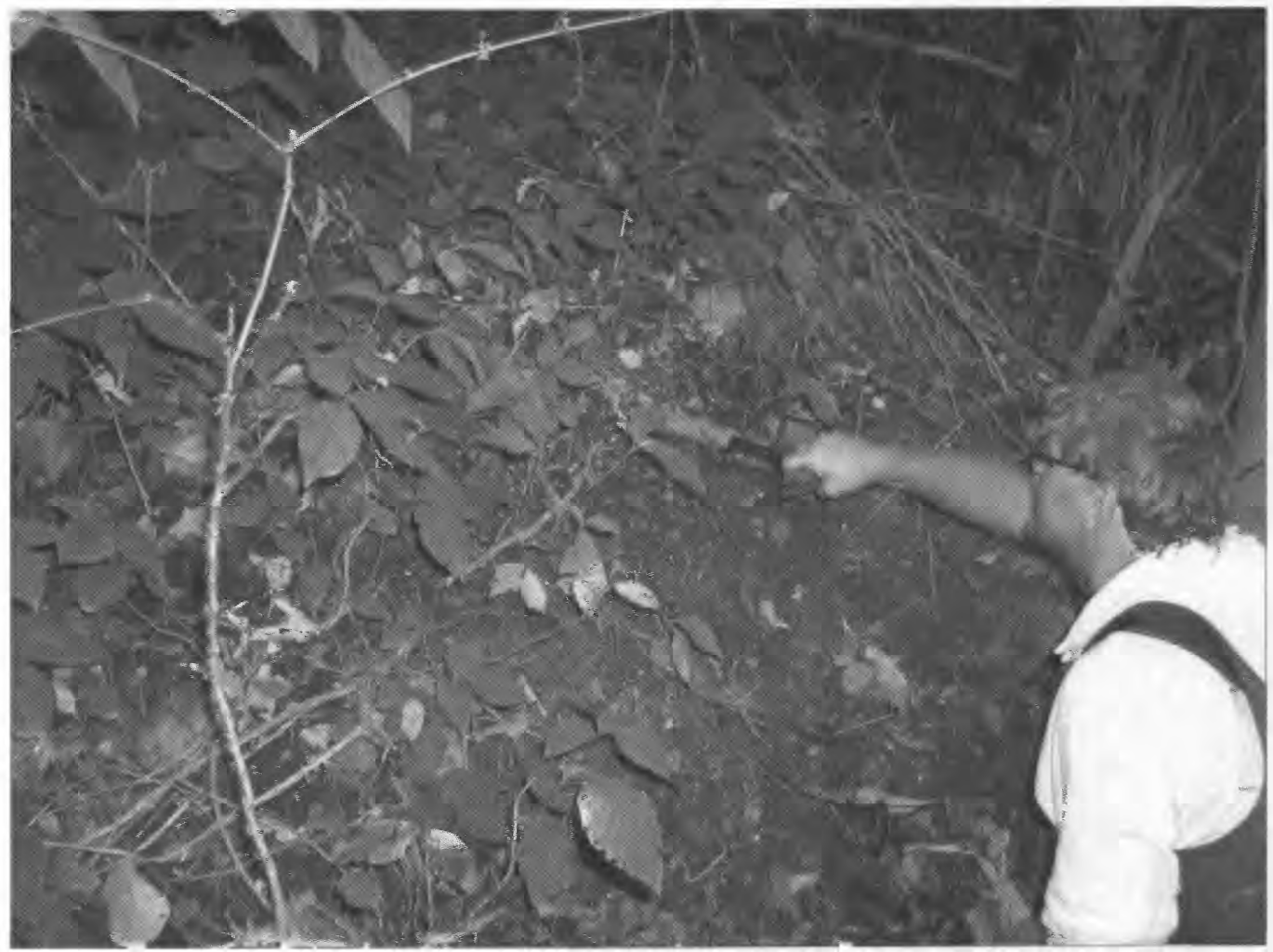

High-water mark W14.8 is a fair wash line on right bank, 10 feet upstream from bridge, at elevation 408.6 feet above sea level. 


\section{SITE DESCRIPTION}

Site W15 (USGS water-quality station 01367735): Wallkill River at State Route 23 near Hamburg, N.J.

Site Location: Bridge on State Road 23, Lat $41^{\circ} 10^{\prime} 01^{\prime \prime}$ long $74^{\circ} 35^{\prime} 13^{\prime \prime}$, NAD 1927. Drainage area: 51.0 square miles

Wantage Township, Sussex County, New Jersey, Community 340562

Hamburg USGS 7.5' Topographic Quadrangle

High-Water Marks: Five high-water marks were flagged, but none were rated: all five were debris lines. Photos of each high-water mark are attached. No GPS readings taken at the marks.

High-water marks flagged and photos taken by J.F. Dudek and G.M. Bosonetto on September 13, 2000. Surveying was completed on October $23,2000$.

High-water-mark elevations were surveyed from benchmark V13.

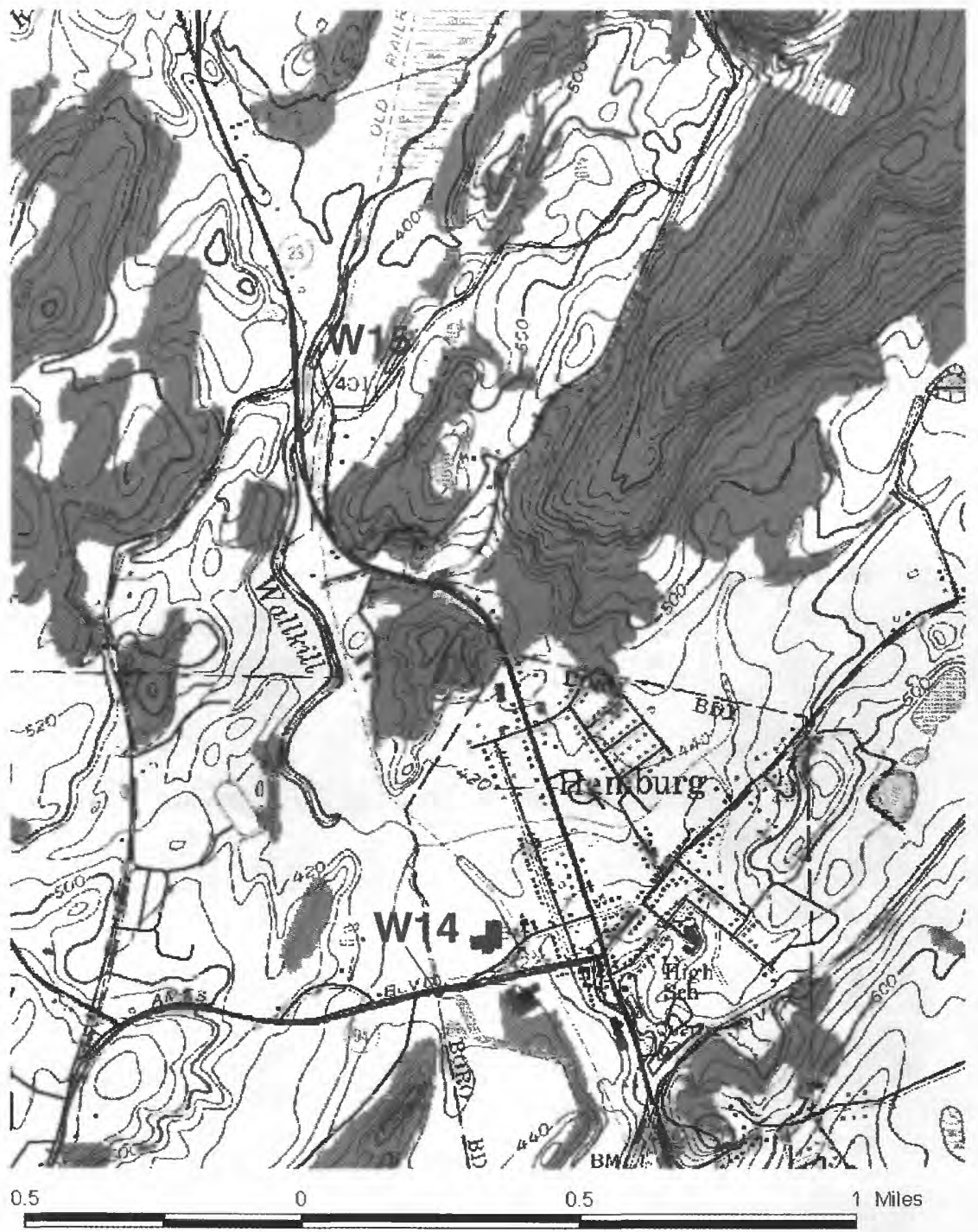

Hamburg quad map showing location of site W15 (01367735), Wallkill River at State Route 23 near Hamburg, N.J. 
Site W15 (01367735) Wallkill River at State Route 23 at Hamburg, N.J.

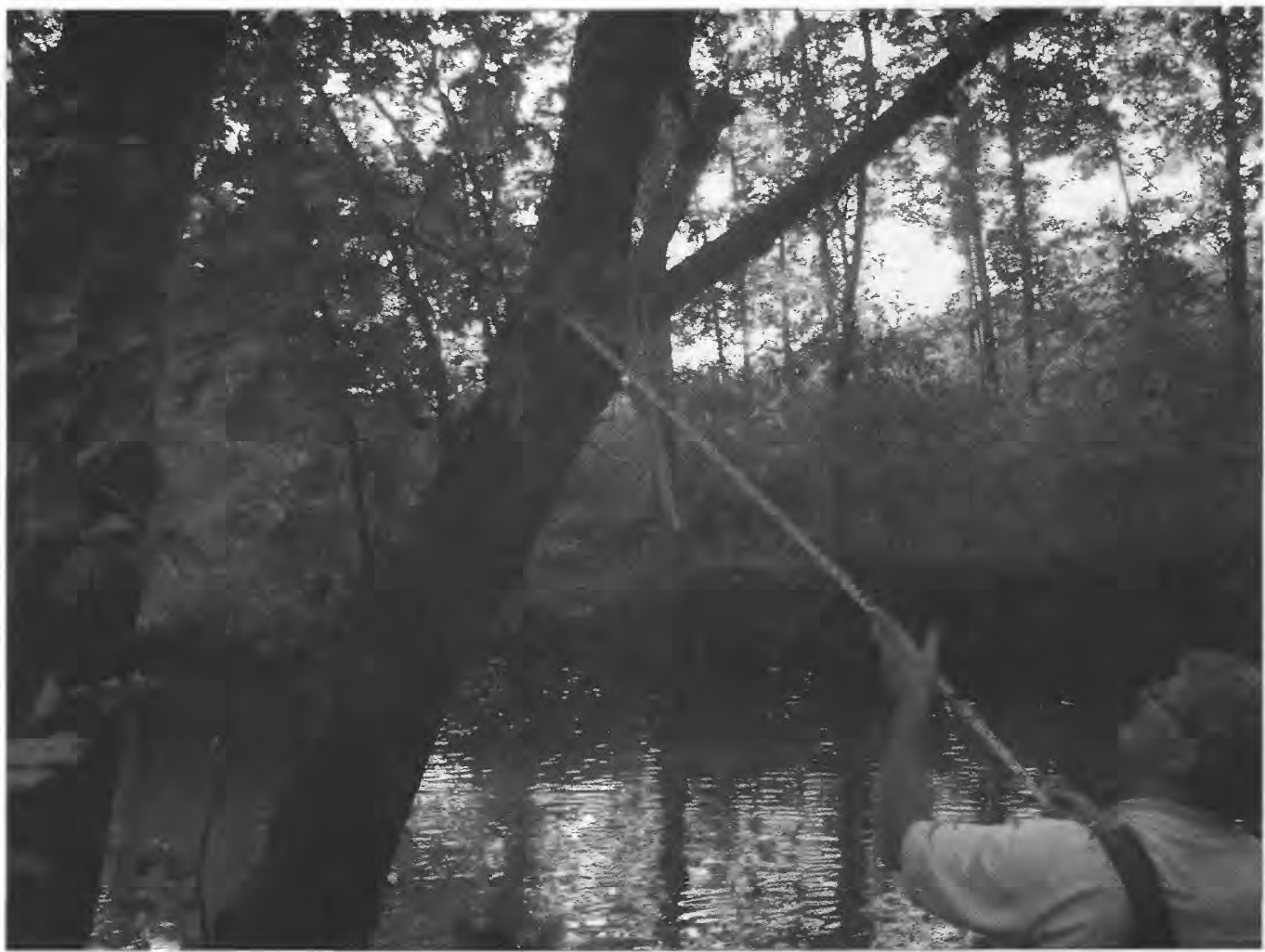

High-water mark W15.1 is a debris line, on right bank, 200+ feet upstream from bridge, on maple tree hanging over water, $6+$ feet above ground, at elevation 400.0 feet above sea level.

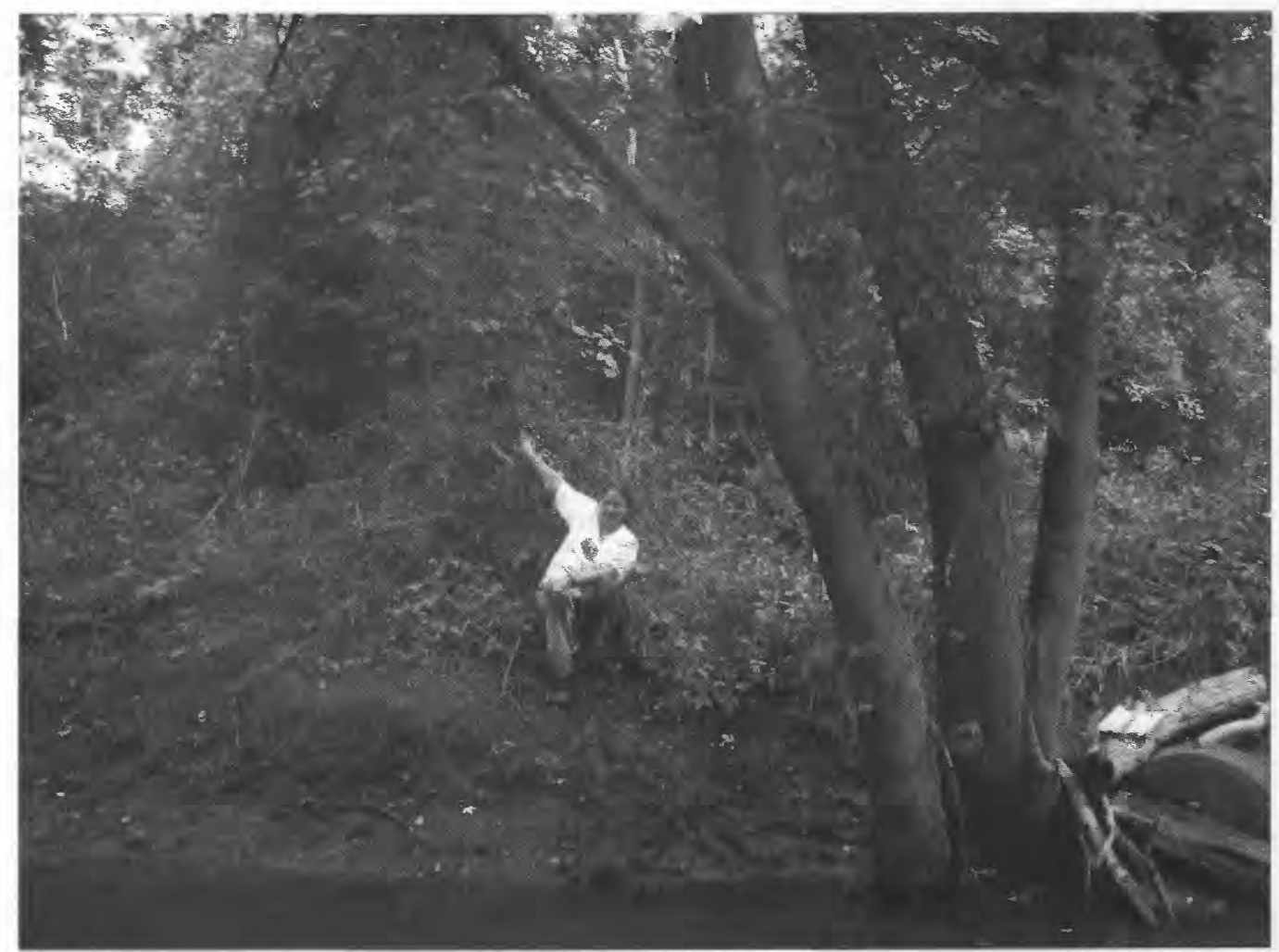

High-water mark W15.2 is a debris line, on right bank, 10 feet downstream from end of bridge wingwall, on maple tree at edge of water, 7.0 feet above ground, at elevation 400.7 feet above sea level. 
Site W15 (01367735) Wallkill River at State Route 23 at Hamburg, N.J.

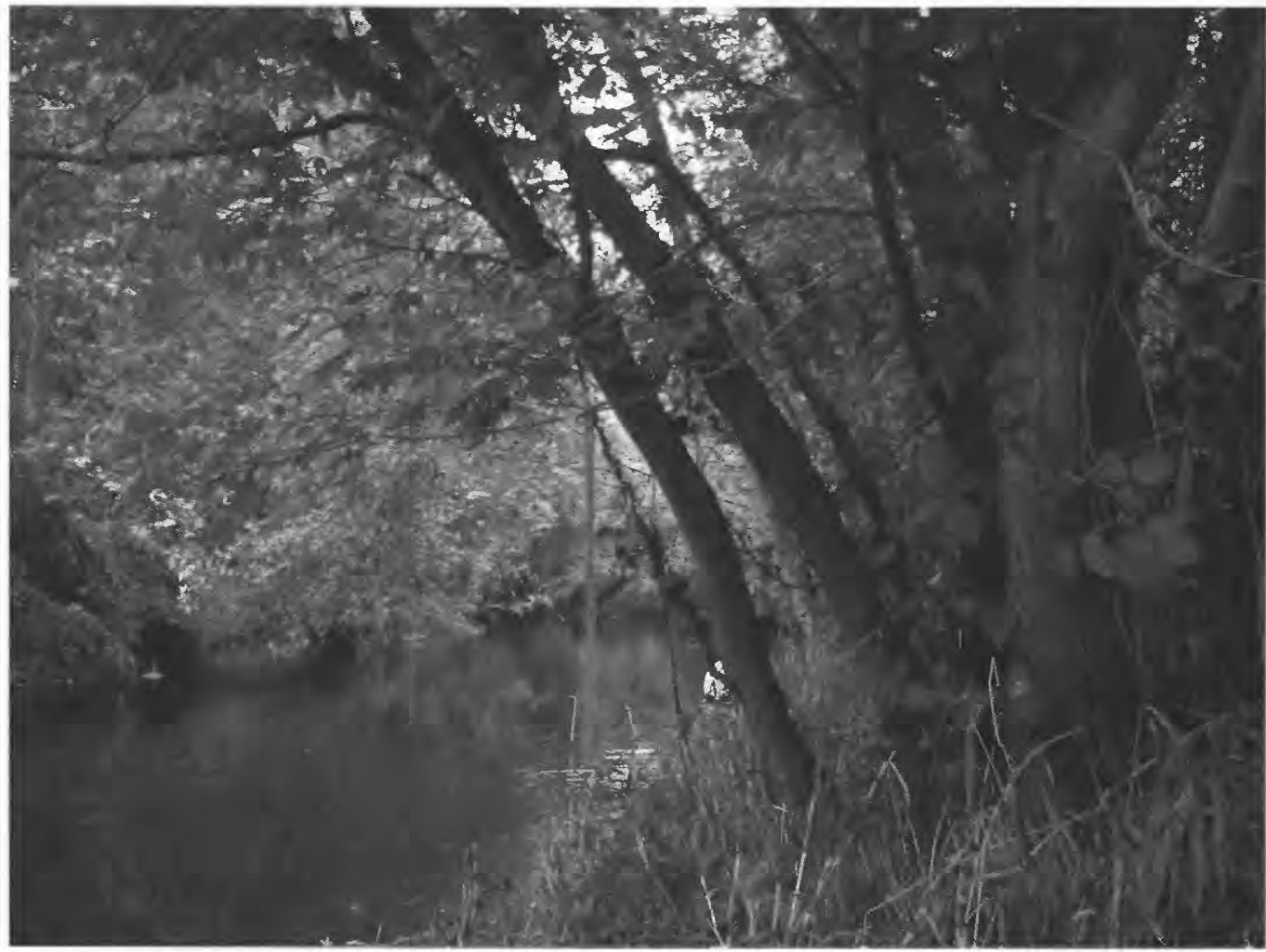

High-water mark W15.3 is a debris line, on right bank, 25 feet downstream from end of bridge wingwall, on maple tree near edge of water, at elevation 399.1 feet above sea level.

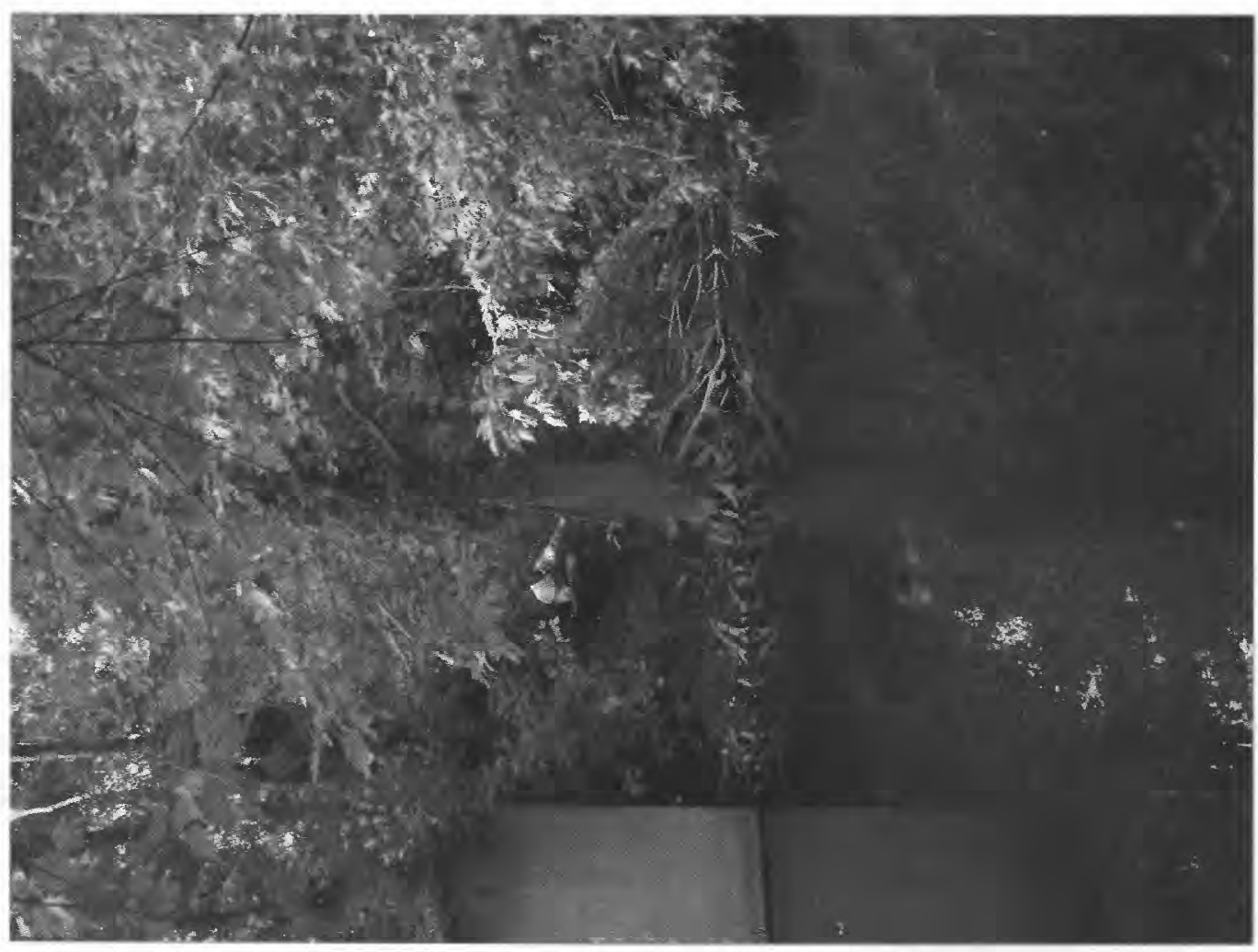

High-water mark W15.4 is a debris line, on tree, on left bank, 25 feet downstream from bridge, near end of wingwall, and 6.8 feet above water surface, at elevation 399.6 feet above sea level. 
Site W15 (01367735) Wallkill River at State Route 23 at Hamburg, N.J.

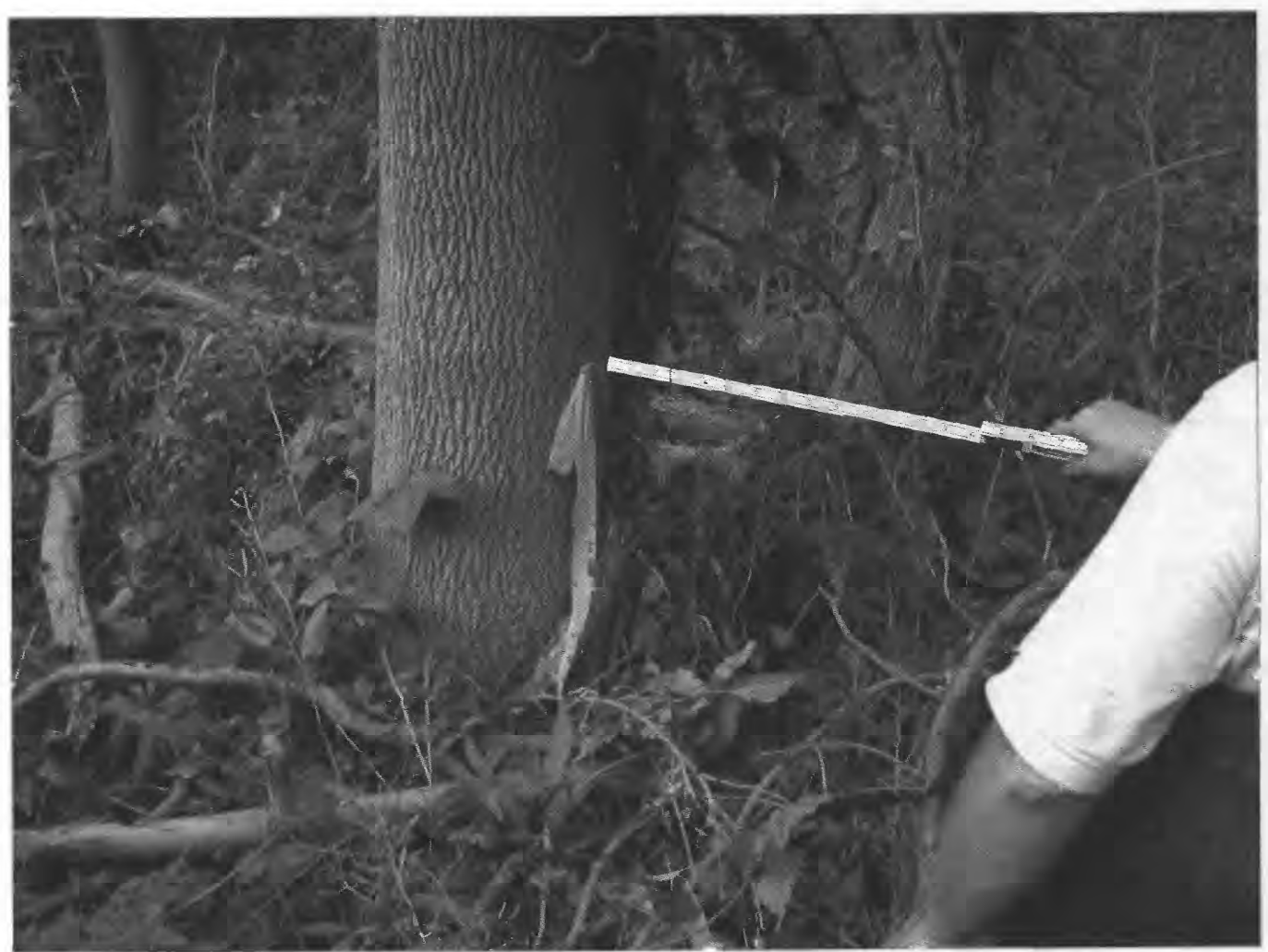

High-water mark W15.5 is a debris line, on tree, on left bank, 45 feet upstream from bridge, and 2.3 feet above ground, at elevation 399.5 feet above sea level. 


\section{SITE DESCRIPTION}

Site W16 (USGS stream-gaging station 01368000): Wallkill River at Owens Station Road near Unionville, N.Y.

Site Location: Bridge on Owens Station Road, Lat 4115'36" long 74³2'56", NAD 1927.

Wantage Township, Sussex County, New Jersey, Community 340562

Unionville USGS 7.5' Topographic Quadrangle

High-Water Marks: Five high-water marks were flagged: 1 excellent debris line, 2 good debris lines, 2 unrated seed lines, and fair cork line on crest-stage gage.

Photos of each high-water mark are attached. No GPS readings taken at the marks.

High-water marks flagged and photos taken by J.F. Dudek and G.M. Bosonetto on September 13, 2000.

The discontinued USGS gage at the site was previously surveyed to sea level. Surveying was not necessary for this study. Datum of the gage is 376.28 feet.

A high-water mark on the crest-stage gage was used to compute elevation and discharge. Gage height of the mark on the crest-stage gage is 8.89 feet. Elevation is 385.17 feet above sea level. A hand level was used to confirm elevation of crest-stage mark with respect to other high-water marks at the site.

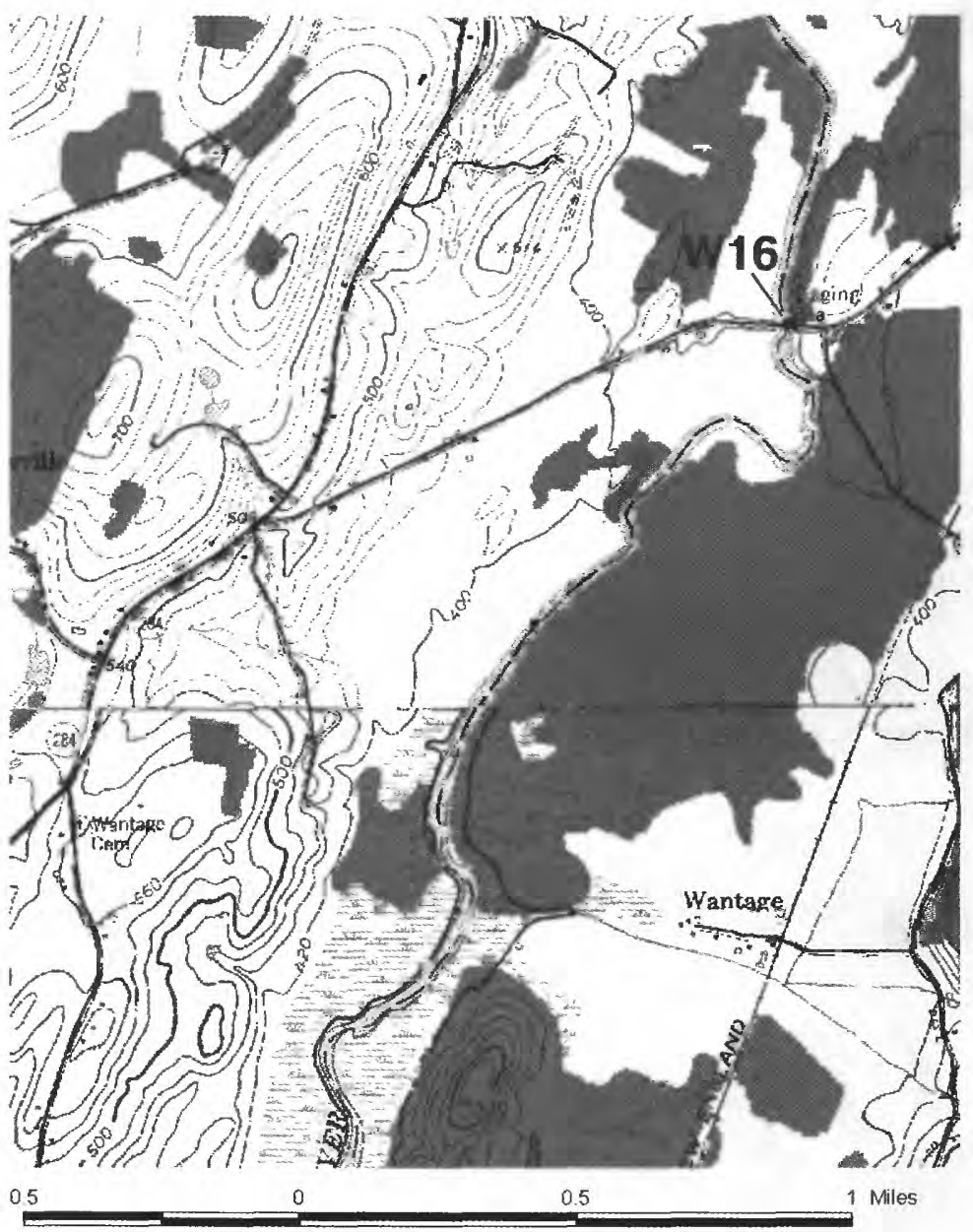

Unionville quad map showing location of site W16 (01368000), Wallkill River at Owens Station Road near Unionville, N.Y. 
Site W16 (01368000) Wallkill River at Owens Station Road at Unionville, N.J.

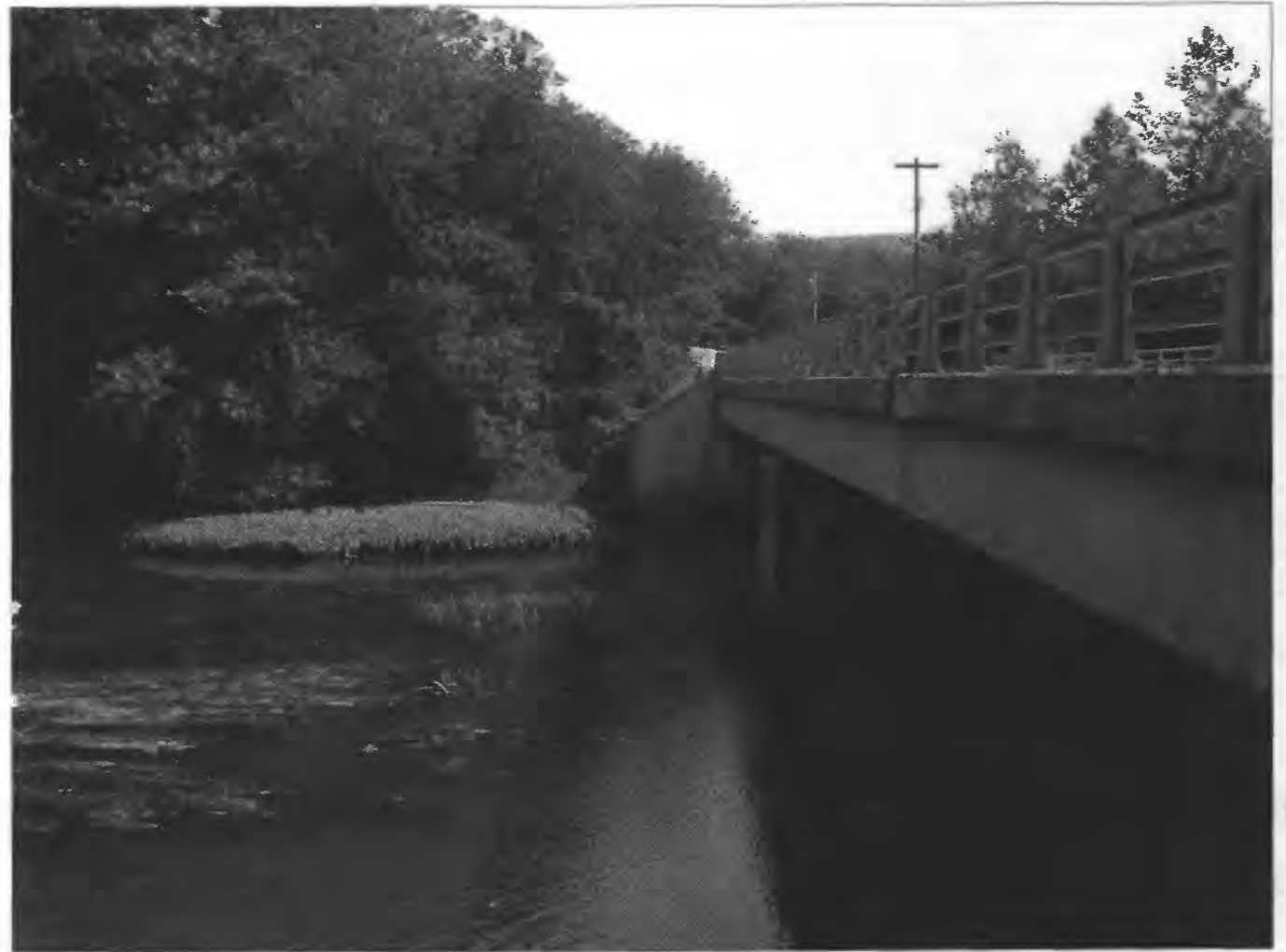

High-water mark W16.4 is a seed line on the staff gage attached to the downstream right wingwall of the bridge, at elevation 388.1 feet above sea level. 
Appendix 2. Summary of indirect discharge measurements made at Glen Brook near Sparta, N.J., and Russia Brook tributary at Milton, N.J. 


\title{
Indirect Measurement Summary
}

\section{Glen Brook near Sparta, N.J.}

\author{
Hudson River Basin
}

\section{Flood of August 12, 2000}

Type of measurement.--A three-section slope area measurement was used to compute the peak discharge for the flood of August 12, 2000. The slope area computation (SAC) computer program was used to calculate discharge. SAC is documented in USGS OFR 94-360 (Fulford, 1994).

Location of site.--Lat $41^{\circ} 02^{\prime} 16^{\prime \prime}$ long $74^{\circ} 36^{\prime} 47^{\prime \prime}$, Sussex County, Hydrologic Unit 02020007,200 feet upstream from unnamed tributary draining Sunset Lake, 0.3 mile downstream from Glen Lake dam, and 1.3 miles northeast of Sparta.

Survey of site.--The site was selected and high-water marks were flagged by D.A. Stedfast and R.G. Reiser on September 12, 2000. Highwater marks are fair to good debris and wash lines. The site was surveyed by R.G Reiser, R.I. Edwards, and G. Holzer cn September 18, 2000. A reference mark was established to an arbitrary datum of 10 feet at the downstream end of the slope area reach. Nine digital photographs of the reach and cross sections were taken on September 18, 2000.

Discharge and gage height.--2,520 cubic feet per second; no gage height.

Main channel " $n$ " values were $0.083,0.083$, and 0.085 for sections 1,2 , and 3 , respectively. The " $n$ " value for the floodpla $n$ is estimated to be 0.05 for each section. This is based on firm soil $=0.03$ plus moderately dense grass, weeds, and seedlings $=0.02$.

Drainage area.--3.68 square miles.

Unit discharge.-- 685 cubic feet per second per square mile.

Nature of flood.-- Flood from heavy localized thunderstorm on August 12, 2000.

Field Conditions. -The reach selected is 200 feet long and fairly straight. The stream bends to the right above the reach and there is a slight bend to the right at the upper end of the reach. The bend causes higher water-surface elevations on the left side of the channol. Water-surface elevation is 1.7 feet higher on the left bank than on the right bank at cross section 1 . At cross section 3 at the downstream end of the reach, the difference in water-surface elevation is reduced to 1.0 foot. Bank erosion is prevalent along both banks and is most severe along the left bank at the upstream end of the reach.

Flow was contained in the channel on the left bank with a small amount of bank overflow at the lower end of the reach. The water surface topped the bank along the right side. Approximately 10 feet of the cross-sectional width at peak flow was across the floodplain on the right side. Froude numbers ranged from 0.68 to 0.81 , indicating subcritical flow. Mean cross-sectional depths averaged about 5 feet, with maximum depths of 8.9 feet in section 1 and 7.5 feet in sections 2 and 3 .

The width of the stream channel at base flow is 13 to 20 feet. The channel consists of cobbles and scattered boulders. The largest boulders are 3 to 4 feet in diameter. The left bank is characterized by exposed roots, boulders, and areas of eroded soils. The right bink is less eroded and has a shallower drop from top of bank to bottom of bank. The part of the channel on the floodplain consists of tall grass, briars, and saplings with a few scattered large trees. A fallen hemlock tree between sections 1 and 2 caused backwater along the right bank at peak flow.

Sections 1,2, and 3 were subdivided into the main channel and right bank overflow sections because of differences in rough ness coefficients (" $n$ " values). The $n$ values for the main channel were estimated three different ways: (1) using a procedure published in USGS Water-Supply Paper (WSP) 2339 (Arcement, 1989); (2) comparisons to reaches published in USGS WSP 1849 (Barnes, 1967); and (3) from an equation developed by Robert Jarrett for steep-gradient streams published in USGS WSP 2310 (Jarrett, 1986). Estimates from Jarret.'s equation were considered to be most accurate. 
$\mathrm{n}=0.39 \mathrm{~S}^{0.38} \mathrm{R}^{-0.16}$

where $\mathrm{n}=$ Manning's roughness coefficient

$S=$ friction slope or energy gradient, and

$\mathbf{R}=$ hydraulic radius,

Calculations.- Fall Water-surface slope Discharge Froude Number Conveyance ratio Channel conveyance

$\begin{array}{lllllll}\text { Reach } 1-2 & 2.98 & 0.036 & 2,630 & 0.74 & 1.13 & \text { contracting }\end{array}$

$\begin{array}{lllllll}\text { Reach 2-3 } & 2.08 & 0.035 & 2,680 & 0.81 & 1.03 & \text { contracting }\end{array}$

$\begin{array}{lllllll}\text { Reach 1-3 } & 5.06 & 0.035 & 2,760 & 0.78 & 1.17 & \text { contracting }\end{array}$

$\begin{array}{lllllll}\text { Multiple 1-3 } & 5.06 & 0.035 & 2,360 & 0.68 & 1.17 & \text { contracting }\end{array}$

Use 2,520 cubic feet per second.

Evaluation.-This indirect measurement is rated fair. Nine of the high-water marks were rated fair and eight were rated good or excellent. Distances between marks on the left bank range up to 50 feet. The estimates of discharge for each reach are very close. The reliability of the n-value estimates is rated fair. The average of the discharges calculated for each of the three reaches and the estimate from the multiplereach calculation was chosen as the peak discharge.

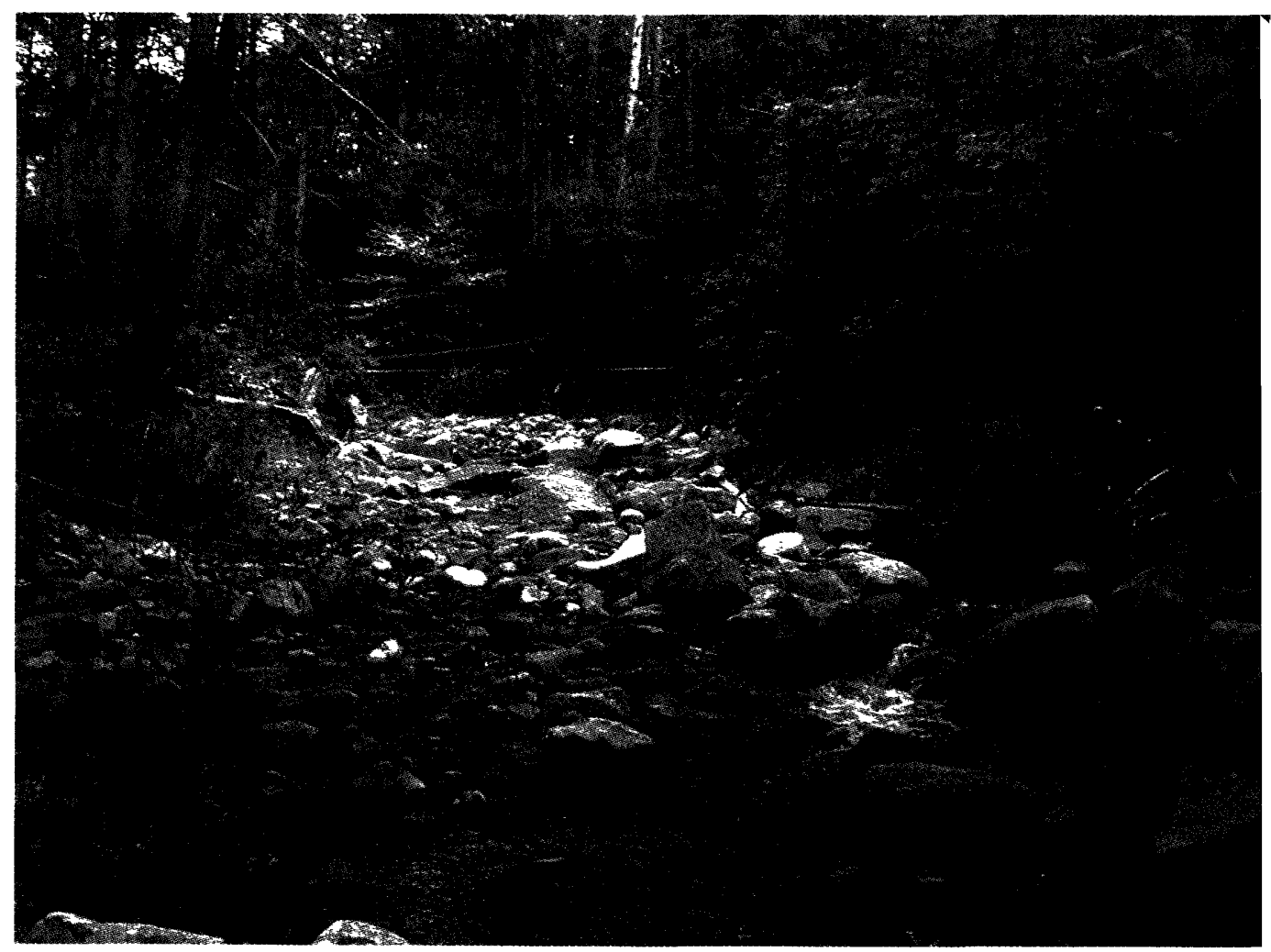

View looking upstream from downstream end of slope area reach at Glen Brook near Sparta, N.J.

Summary prepared by Robert G. Reiser, September 28, 2000.

Checked by John F. Dudek U.S. Geological Survey, December 5, 2000.

Reviewed by Larry A. Weiss, retired surface-water specialist, U.S. Geological Survey Connecticut District, Fetruary 6, 2001 


\title{
Indirect Measurement Summary
}

\section{Russia Brook tributary at Milton, N.J.}

\author{
Passaic River Basin
}

\author{
Flood of August 12, 2000
}

Type of measurement.--A three-section slope area measurement was used to compute the peak discharge for the flood of August $12,2000$. The slope area computation (SAC) computer program was used to calculate discharge. SAC is documented in U.S. Geological Survey (USGS) Open-File Report 94-360 (Fulford, 1994).

Location of site.--Lat $41^{\circ} 01^{\prime}$ 04” long $74^{\circ} 32^{\prime} 30^{\prime \prime}$, Morris County, Hydrologic Unit 02030103, 0.2 mile southwest of Milton, 0.3 mile upstream from confluence with Russia Brook, and 1.4 miles upstream from Lake Swannanoa.

Survey of site.-- R.D. Schopp and E.A. Pritchett selected the site and flagged high-water marks on September 12, 2000. Figh-water marks are mostly fair wash lines on the right bank and fair/poor debris lines on the left bank. The site was surveyed by R.G. Reiser, R.I. Edwards, and G. Holzer on September 12 and 13, 2000. The survey was stopped before completion on September 12, 2000, because of rain and was finished on September 13, 2000. The top of the aluminum staff-gage backing was used as the starting reference elevation. The elevation of the top corner of the staff backing was derived by measuring up from 3.30 feet on the staff plate. A chiseled square on the gage house doorsill at approximately the peak elevation at the gage also was surveyed. Station levels were not located. Six digital photographs of the reach and cross sections were taken on September 20,2000. In addition, copies of photographs of the stream at a stage near the peak flow were obtained from the property owner.

Discharge and gage height.-- 650 cubic feet per second; 5.98 feet gage height from seeds on side of gage house.

Drainage area.-- 1.64 square miles.

Unit discharge.-- 396 cubic feet per second per square mile.

Nature of flood.-- Flood from heavy localized thunderstorm on August 12, 2000.

Field Conditions.--The reach selected for the survey is 180 feet long and straight. The upstream end of the reach is 50 feet downstream from the gage house. Large boulders 5 to 6 feet in diameter on both banks mark the beginning of the reach. The water-surface ele.vation is 0.7 foot higher on the left bank than on the right bank at cross section 1. At cross sections 2 and 3 the water-surface elevation is 0.3 and 0.4 foot higher, respectively, on the left bank. Bank erosion was minimal. Root mass and embedded cobbles held most of the soil in place along both banks.

Flow was contained within the channel on both banks. Froude numbers ranged from 0.60 to 0.86 , indicating subcritical fow. Mean crosssectional depths were from 2.2 to 2.9 feet, with maximum depths of $4.2,4.8$, and 3.6 feet in sections 1,2 , and 3 , respectively.

The width of the stream channel at base flow is 10 to 20 feet. The channel consists of cobbles and scattered boulders. The largest boulders scattered along the banks are 5 to 6 feet in diameter at the upstream end of the reach and 3 to 4 feet in diameter at the down rteam end of the reach.

Sections 1, 2, and 3 were subdivided into the main channel and two side channels. The " $n$ " values for the main channel were estimated by three different methods: (1) using a procedure published in USGS Water-Supply Paper (WSP) 2339 (Arcement, 1899); (2) romparisons with data and photographs from other reaches published in USGS WSP 1849 (Barnes, 1967); and (3) from an equation developid by Robert Jarrett for steep-gradient streams published in USGS WSP 2310 (Jarrett, 1986). Estimates from Jarrett's equation were considered to be the least subjective and most defensible of the three methods. The water-surface slope meets the criteria for the steep-gradient stream classification $(>0.01)$. 
$\mathrm{n}=0.39 \mathrm{~S}^{0.38} \mathrm{R}^{-0.16}$

where $\mathrm{n}=$ Manning's roughness coefficient,

$\mathrm{S}=$ friction slope or energy gradient, and

$\mathrm{R}=$ hydraulic radius.

Main channel " $n$ " values were computed to be $0.091,0.093$, and 0.076 for sections 1,2 , and 3, respectively.

Side channel " $n$ " values were estimated to be 0.110 .

$\begin{array}{lrccccc}\text { Calculations.--Fall } & \text { Water-surface slope } & \text { Discharge } & \text { Froude Number Conveyance Ratio Channel Conveyance } \\ \text { Reach 1-2 } & 2.30 & 0.046 & 732 & 0.64 & 1.29 & \text { contracting } \\ \text { Reach 2-3 } & 1.65 & 0.027 & 549 & 0.60 & 0.92 & \text { slight expansion } \\ \text { Reach 1-3 } & 3.95 & 0.035 & 691 & 0.86 & 1.19 & \text { contracting } \\ \text { Multiple 1-3 } & 3.95 & 0.035 & 637 & 0.79 & 1.19 & \text { contracting }\end{array}$

Use 647 cubic feet per second.

Evaluation.-- This indirect measurement is rated fair/poor. Most of the high-water marks are rated fair. Some of the high water marks on the left bank are poor. The estimates of peak discharge in reach 1-2 and reach 2-3 differ by 33 percent. The average of the disch arges for section 1-3 and the multiple-section calculation was chosen as the peak discharge. The reliability of the " $n$ " value estimates is rated fair.

Remarks.--Rating number 4.0 was extended to reflect this indirect measurement. New rating number 4.1 was created.

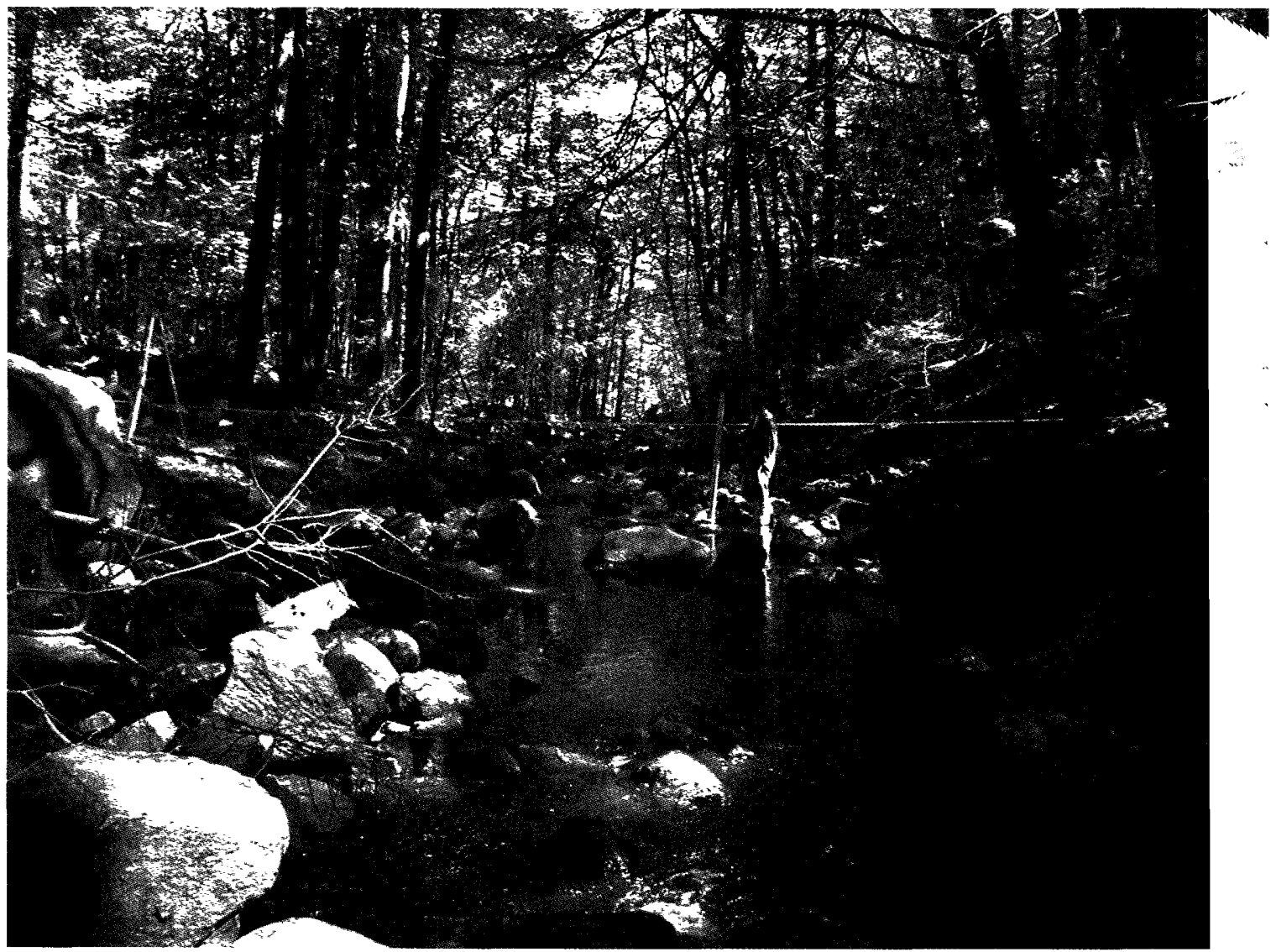

View looking downstream from upstream end of reach at Russia Brook tributary at Milton, N.J.

Summary prepared by Robert G Reiser, September 28, 2000.

Checked by John F. Dudek, U.S. Geological Survey, December 5, 2000.

Reviewed by Larry A. Weiss, retired surface water specialist, U.S. Geological Survey Connecticut District, February 6, 2001. 
Printed on recycled paper 